Universidade de São Paulo

Faculdade de Educação

Maurício Liberal Augusto

\title{
A narrativa cativa
}




\section{Maurício Liberal Augusto}

\section{A narrativa cativa}

Tese apresentada à Faculdade de Educação da Universidade de São Paulo para obtenção do título de Doutor em Educação.

Área de concentração: Filosofia e Educação

Orientador: Prof. Dr. Livre-Docente José Sérgio Fonseca de Carvalho 
AUTORIZO A REPRODUÇÃO E DIVULGAÇÃO TOTAL OU PARCIAL DESTE TRABALHO, POR QUALQUER MEIO CONVENCIONAL OU ELETRÔNICO, PARA FINS DE ESTUDO E PESQUISA, DESDE QUE CITADA A FONTE.

Catalogação na Publicação

Serviço de Biblioteca e Documentação

Faculdade de Educação da Universidade de São Paulo

375.42 Augusto, Maurício Liberal

A923n A narrativa cativa / Maurício Liberal Augusto; orientação José Sérgio Fonseca de Carvalho. São Paulo: s.n., 2013.

$171 \mathrm{p}$.

Tese (Doutorado - Programa de Pós-Graduação em Educação. Área de Concentração: Filosofia e Educação) - - Faculdade de Educação da Universidade de São Paulo.

1. Ensino de história 2. Educação 3. Política 4. Narrativa 5. Arendt, Hannah I. Carvalho, José Sérgio Fonseca de, orient. 
Nome: AUGUSTO, Maurício Liberal

Título: A narrativa cativa

Tese apresentada à Faculdade de Educação da Universidade de São Paulo para obtenção do título de Doutor em Educação.

Área de concentração: Filosofia e Educação

Orientador: Prof. Dr. Livre-Docente José Sérgio Fonseca de Carvalho

Aprovado em:

Banca Examinadora

Prof. Dr. Instituição:

Julgamento: Assinatura:

Prof. Dr. Instituição:

Julgamento: Assinatura:

Prof. Dr. Instituição:

Julgamento: Assinatura:

Prof. Dr. Instituição:

Julgamento: Assinatura:

Prof. Dr. Instituição:

Julgamento: Assinatura: 
A Carolina,

pelas histórias que conta aos nossos filhos, pelo encanto que é

e pelo cuidado que tem.

$\mathrm{O}$ inverno

lá no Canto do Bugio

este ano se prolongou.

Mas apesar do frio intenso,

da lareira apagada e das amoras

de um setembro esquecido,

você foi meu sol.

Foi, é e seguirá sendo

a melhor história que poderei contar. 


\section{Agradecimentos}

Ao longo da trajetória, contraí dívidas com pessoas queridas às quais devo agradecer.

A Rosa Maria, minha mãe, pelo intenso amor e pelo incentivo constante. Não foram poucas as vezes em que ela se viu assumindo responsabilidades que não eram suas, como cuidar dos meus filhos, entretê-los com brincadeiras, levá-los a um passeio na Praça Victor Civita, preparar uma comidinha de última hora. Avó dedicada, mãe devota, professora autodidata, ela é para mim um exemplo raro de generosidade e amor.

A Adilson Augusto, meu pai, que abdicou de seu tempo livre para me ajudar na revisão do trabalho. Jornalista, amante da clareza e rigoroso, mas sem dureza, ele se entregou com esmero ao trabalho. A ele sou grato pelo gesto carinhoso, pela generosidade, pelo aprendizado que desfrutei no trato com a língua portuguesa e, fundamentalmente, pelo respeito que teve com o texto. Alegra-me que a leitura tenha despertado nele algumas lembranças de infância, como a história de Marcelino Santos, apresentador do programa Mil e uma noites numa rádio santista. Marcelino, além de apresentar o programa, também fazia a voz do temível Sultão. Os tempos mudaram. O rádio hoje já não abriga nem Marcelinos, nem Sheherazades. Mas tive a felicidade de ter um pai apaixonado pela política - como diria Arendt, aquele espaço que se forma entre pessoas e entre estas e as coisas no cuidado com o mundo -, o que despertou em mim o interesse pela história.

A José Sérgio Fonseca de Carvalho, por acolher a orientação deste trabalho de modo a um só tempo rigoroso e franco, estimulante e desafiador, concedendo a mim ampla liberdade mesmo nos momentos em que eu me desviava do foco (questão sempre recorrente em nossas conversas e troca de e-mails). Estou convencido de que a metáfora da suíte política não foi mero artifício retórico de Arendt, tampouco meu, e também de que meu problema a impunha como uma estratégia narrativa. Os intercâmbios que Zé Sérgio promove entre essa universidade e a escola pública - sem um viés missionário, como tantas vezes se vê testemunha seu compromisso ético e político com uma instituição como a USP, compromisso, aliás, do qual nenhuma universidade pública deveria poder se esquivar. Obrigado por tudo, caro amigo.

Aos professores Elias Thomé Saliba (FFLCH-USP) e Adriano Correia (UFGO), pelas estimulantes críticas na ocasião do exame de qualificação. Tenho consciência de que os parpites azedos de ambos são questões a perdurar. Espero ter adocicado ao menos alguns deles. Ao professor Elias, um tardio agradecimento por ter me iniciado nos labirintos da teoria 
da História, com o bom humor que lhe é peculiar. Confesso que ainda guardo meu caderno com as anotações de suas aulas, sempre estimulantes. Ao Adriano, promessa de uma nova amizade, recordo com alegria nossas conversas por aí em torno da obra de Hannah Arendt. Sou grato pelo intercâmbio que faz com a Faculdade de Educação da USP através do GEEPC.

Aos professores das disciplinas que cursei ao longo do doutorado, pela excelência das aulas ministradas, que ajudaram a formar o escopo dessa pesquisa: Francisco Murari Pires (FFLCH-USP), José Sérgio Fonseca de Carvalho (FEUSP), Marilena Chauí (FFLCH-USP), e Gilda M. de Barros (FEUSP).

À professora Fina Birulés, por me acolher carinhosamente para o cumprimento de um estágio doutoral de quatro meses junto à Universidade de Barcelona e por me permitir desfrutar do Seminário Primaveras Arendtianas, que ela coordena anualmente naquela universidade, onde tive o prazer da companhia de Lorena F. Peiró, Mathias Sirczuc, Stefania Fantauzzi, do professor Manuel Cruz e da acolhedora bibliotecária Margarita P. Alsina, que me facilitou o acesso à biblioteca da instituição. O contato com o trabalho de Fina confirmou que por trás de sua obra há uma pessoa de raro brilho, intensa generosidade e entusiasmo, que compreende a obra de Arendt com maestria, intensidade e afeição. O oceano que nos separa me faz lembrar que escribir és una forma de regresar.

À professora Carlota Reis Boto (FEUSP), por assumir a responsabilidade da orientação ao longo do período que meu orientador cumpria um pós-doutorado na Universidade Paris VII. Não foram raras as ocasiões em que tivemos de lidar com papéis e assinaturas para viabilizar meu estágio em Barcelona. Foi ela também quem presidiu meu exame de qualificação, tecendo argutas e generosas observações que procurei incorporar ao trabalho.

Ao Grupo de Estudos sobre Educação e o Pensamento Contemporâneo (GEEPC) coordenado por meu orientador na FEUSP -, em cujas discussões se deu o desenvolvimento desta tese. Registro aqui meu reconhecimento aos colegas do grupo e às suas inestimáveis contribuições ao trabalho. Esta pesquisa reflete a vívida troca de ideias de nossos encontros semanais, um estímulo sempre renovado da atividade do pensar. A Crislei, um agradecimento especial pela acuidade de sua crítica, fundamental na revisão de dois capítulos do trabalho.

Aos funcionários da Secretaria de Pós-Graduação da FEUSP, que além do profissionalismo no atendimento, foram sempre gentis e atenciosos. Ao Marcelo, em especial, sou grato pelos inúmeros esclarecimentos prestados e pela imprescindível segurança 
transmitida ao longo dos quatro meses do estágio em Barcelona, fazendo uma ponte oceânica entre mim e a CAPES.

À Fundação de Amparo à Pesquisa do Estado de São Paulo (FAPESP) - assim como ao seu parecerista anônimo -, pela bolsa concedida, e à Coordenação de Aperfeiçoamento de Pessoal de Nível Superior (CAPES), pela bolsa de doutorado-sanduíche que me permitiu cumprir um estágio doutoral na Universidade de Barcelona.

Aos amigos próximos ou distantes que ficaram de quarentena: Edson Ribeiro do Valle, Victor Castellano, Sonia Carbonel. E àqueles que há muito preciso resgatar: Rubens Curcio, Rogers Gomes, Marcelo Zochio, Lizanias Lima, Miguel Castilho, Jacó Moura, Ricardo Paim.

A Elisa Vieira, pela gentileza de formatar o trabalho, revisá-lo, padronizar as notas, e pela força na composição do abstract. Desculpe-me pela saia justa!

Aos meus tios Fernanda (in memorian) e Lemar, e aos primos Henrique, Ricardo, Patrícia e Fernando, pelo interesse que sempre demonstraram pelo trabalho, eles que também são ou foram educadores.

Aos meus filhos, Natanael e Carolzinha (bem-vinda, filha querida!), que iluminam com encanto, alegria e humor a vida daqueles ao seu redor e que nos meses finais de minha escrita se viram privados da companhia do pai. Em dezembro de 2012, antes de completar 6 anos, Natanael soltou a seguinte frase: "Olha pro mundo, senão ele passa, fica velinho por causa da tristeza". É, filho, o papai andou muito ocupado com o mundo, mas agora vamos poder olhar nos olhos um do outro e brincar e brincar e brincar...

Por fim, a Carolina, sem a qual este trabalho sequer existiria. A coragem de assumir sozinha a responsabilidade por Natanael nos meses em que cumpri estágio em Barcelona testemunha sua generosidade, sua abnegação e seu estímulo incondicional para que o trabalho pudesse se desenvolver da melhor forma possível. Impus a ela sacrifícios muito além do que seriam razoáveis, especialmente nos meses finais. Espero poder retribuir todo esse afeto agora que o trabalho, a ela dedicado, chegou ao fim. Dias melhores virão! 


\section{Resumo}

AUGUSTO, Maurício Liberal. A narrativa cativa. 2013. 171f. Tese (Doutorado em Educação) - Faculdade de Educação, Universidade de São Paulo, São Paulo, 2013.

Nas décadas de 1980 e 1990, no Brasil, desenvolveu-se nos meios acadêmicos de História um amplo consenso para o combate a um suposto ensino tradicional, que deveria ser substituído por um processo de renovação. Como um eco tardio, o debate em torno do assunto foi claramente permeado pelo fervor militante presente nas duas décadas de ditadura militar e pelos bem-sucedidos esforços em prol da redemocratização. Seus proponentes tomaram a Nova História como fonte primordial para canalizar os esforços em prol da renovação do ensino de História. Esta tese toma como referência a obra de Hannah Arendt, que não era historiadora, tampouco educadora em sentido estrito - talvez por essa razão seu olhar seja fecundo para se contrapor àquele consenso renovador -, e procura mostrar que, nas circunstâncias em que se deu, tal consenso inclinou-se para a rejeição pura e simples do dito ensino tradicional e para o uso recorrente do pressuposto de que só é possível conhecer e compreender aquilo que nós mesmos fizemos. Ao mesmo tempo, e contrariando seus propósitos libertários, aquele consenso renovador procurava, sem o admitir, substituir a iniciação dos jovens nos meandros da História por uma oficina da História com vistas a transformá-los em pequenos historiadores. Ao revelar esse conjunto de atitudes, tomadas por uma comunidade autorreferente, o presente trabalho pretende reforçar a indiscutível distinção entre universidade e escola implicitamente negada pelos referidos renovadores, além de recuperar o sentido formativo da História à luz da obra de Hannah Arendt, sobretudo no que diz respeito ao significado que a autora confere à narrativa histórica. Do mesmo modo, procura mostrar que a pretendida renovação, ao transportar a teoria e a prática historiográficas para as práticas de ensino dessa disciplina, acarretou o obscurecimento do sentido formativo da História. Partindo de uma metáfora musical utilizada por Arendt no prefácio de Entre o passado e o futuro, a tese se emoldura tal qual uma suíte. A política, a história e a educação representam três vozes distintas e relacionadas da reflexão teórica de Arendt que convergem, ao final, para iluminar o sentido formativo do ensino de História.

Palavras-chave: Ensino de História; Educação; Política; Narrativa; Hannah Arendt. 


\begin{abstract}
AUGUSTO, Maurício Liberal. The captive narrative. 2013. 171f. Tese (Doutorado em Educação) - Faculdade de Educação, Universidade de São Paulo, São Paulo, 2013.

During the 1980s and 1990s, in Brazil, a widespread consensus has been developed inside the academic community of History against a supposed traditional teaching, which should be replaced by a renovation process. As a late echo, the discussions about this issue were clearly influenced by the militant fervor characteristic of the two decades of military dictatorship and by the successful initiatives for the reestablishment of democracy. The proposers adopted the Nouvelle Histoire as the primal source to conduct the efforts in favor of the History teaching renovation. This thesis takes as an important reference the work of Hannah Arendt, who was not a historian, neither an educator in a strict meaning - perhaps this is the reason why her perspective is so fertile to make an opposition to that renovator consensus -, and intends to demonstrate that, in the circumstances in which it happened, the consensus tended to the simple and pure rejection of the so-called traditional teaching and to the recurrent use of the conjecture that only is possible to know and understand what we did by ourselves. At the same time, and contradicting its libertarian purposes, that renovator consensus looked for although it did not admit - replacing the initiation of young people in the meanders of History by a workshop of History in order to convert them into small historians. By revealing this set of attitudes, adopted by a self-referential community, this work aims to emphasize the unquestionable distinction between university and school implicitly denied by the mentioned renovators; it also aims to recover the formative sense of History in light of Hannah Arendt's work, particularly in relation to the meaning that the author attributes to the historical narrative. Furthermore, it attempts to show that the desired renewal, by carrying the historiographical theory and practice to the teaching practices of this discipline, led to the obscuration of the formative sense of History. Based on a musical metaphor used by Arendt in the preface to Between past and future, the thesis is framed just like a suite. Politics, history and education represent three distinct and related voices of Arendt's theoretical reflection which converge, at the end, to illuminate the formative sense of History teaching.
\end{abstract}

Keywords: History teaching; Education; Politics; Narrative; Hannah Arendt. 


\section{Sumário}

Uma suíte política para tempos sombrios 10

1.1. O ator, o espectador e a faculdade do juízo: primeira aproximação 16

1.2. A narrativa como regresso (1933-1951) 23

$\begin{array}{ll}\text { 1.3. O desafio de pensar por si mesma } & 27\end{array}$

1.4. O exílio e a descoberta de uma tradição oculta 32

1.4.1. Rahel Varnhagen: a dádiva da judeidade $\quad 40$

1.5. O direito à opinião (doxa) 45

2. História, compreensão e reconciliação com o mundo 49

2.1. Afrontando o cânone historiográfico 49

2.2. Conhecimento e compreensão: verdade e sentido 55

2.3. Mortal, natal e apátrida

$\begin{array}{ll}\text { 2.3.1. Mortalidade do homem e imortalidade da natureza } & 62\end{array}$

2.4. Poesia e historiografia 66

2.5. A ação entre a guerra homérica e a polis pré-platônica 74

3. A história como um processo feito pelo homem $\quad 77$

$\begin{array}{ll}\text { 3.1. Dando as costas à imortalidade } & 78\end{array}$

3.2. A alienação do homem em face do mundo 83

3.3. Descartes e a dúvida moderna $\quad 87$

3.4. G. Vico: verum et factum convertuntur

3.5. Marx e a substituição da ação (práxis) pela fabricação (poiésis) 92

4. Política e educação: fronteiras 100

4.1. A educação como instrumento da política 100

4.2. Fundando uma nova ordem 102

4.3. Acolher os novos e dizer: isto é o mundo 105

$\begin{array}{ll}\text { 4.3.1. A dignidade da ação política } & 108\end{array}$

4.3.2. A dimensão política da natalidade no âmbito da educação 114

$\begin{array}{ll}\text { 4.4. Uma herança sem testamento } & 118\end{array}$

5. O ensino como oficina da História $\quad 122$

$\begin{array}{lr}\text { 5.1. Quando a teoria inventa a prática } & 122\end{array}$

5.2. Quando o processo toma o lugar da coisa em si 129

5.3. Nasce um paradigma $\quad 133$

5.4. Dos Annales à Nova História 137

5.5. A oficina de História à imagem do cavalo de Troia 149

A narrativa cativa $\quad 153$

$\begin{array}{ll}\text { Referências bibliográficas } & 160\end{array}$ 


\section{Uma suíte política para tempos sombrios}

O primeiro contato que tive com a obra de Hannah Arendt, já no terço final de minha pesquisa de mestrado, foi por meio do texto A crise na educação, que integra a coletânea de ensaios Entre o passado e o futuro, de 1961. Desde esse início de diálogo com o pensamento de Arendt ficara em aberto o desejo de ampliar a compreensão de sua obra. O fato é que Entre o passado e o futuro guardava uma importante pista que, dez anos depois, serve de moldura para esta introdução.

No prefácio à coletânea, composta por ensaios produzidos entre os anos 1954 e 1960, Hannah Arendt (1992, p. 41) diz esperar que "o leitor concorde, que o ensaio como forma literária guarda uma afinidade natural com os exercícios que tenho em mente". Ela se refere aos seis exercícios de pensamento político, como diz o subtítulo do livro, infelizmente ignorado na tradução brasileira. Em seguida, recorre a uma metáfora musical para justificar a reunião daqueles textos num livro.

Diz ela que a unidade dos ensaios "não é a unidade de um todo indiviso, mas sim a de uma sequência de movimentos que, como uma suíte musical, são escritos em um mesmo tom ou em tons relacionados" (ARENDT, 1992, p. 42, grifo nosso). Cada ensaio, portanto, encerra um movimento (ou exercício) autônomo, mas relacionado, dessa suíte política. Aqui se fará uma extrapolação da metáfora, pois parece que ela não é mero ornamento do texto com a intenção de persuadir o leitor sobre a unidade da obra. Proponho que não essa obra em especial, mas que o conjunto da obra de Arendt possa ser apreciado da forma como ela apresenta a suíte política que é Entre o passado e o futuro.

Que se escute com mais vagar essa suíte, seus movimentos autônomos, porém integrados numa mesma tonalidade ou em tonalidades relacionadas, como sugere Arendt. Ela indica que a suíte possui três partes - não nomeadas - e que a ordem em que se sucedem os movimentos - os ensaios - não é gratuita. Pode-se ouvi-los aleatoriamente, uma vez que a suposta autonomia dos movimentos garante essa escuta aleatória? Presume-se que sim, mas a autora diz que a "própria seqüência é determinada pelo conteúdo" (ARENDT, 1992, p. 42) de cada movimento, sugerindo uma ordem que, ao menos num primeiro momento, respeite a sequência em que a suíte foi, senão composta, arranjada. As três partes desse arranjo são assim descritas: "A primeira trata da ruptura moderna na tradição e do conceito de História de que se serviu a época moderna, almejando substituir os conceitos da Metafísica tradicional" (ARENDT, 1992, p. 42). 
O primeiro movimento é A tradição e a época moderna; o segundo, $O$ conceito de história: antigo e moderno. Extrapolando a metáfora, percebe-se que, além da relação entre os seis movimentos da suíte, dentro de um mesmo movimento há como que uma polifonia, isto é, ao menos duas vozes distintas e também relacionadas. É imprescindível notar que uma delas representa o passado: a tradição, no primeiro movimento, e o conceito de história legado por gregos e romanos, no segundo (outra forma de referir-se à tradição, ou melhor, a uma parte dela). A outra voz representa o futuro: a época moderna, no primeiro movimento, e o moderno conceito de história, no segundo. Para os propósitos deste trabalho, convém assinalar o destacado lugar que essa voz, a história, ocupa no conjunto da alegada suíte política, e ressaltar que a polifonia se faz presente em cada ensaio individualmente.

Um pouco antes, entretanto, Arendt (1992, p. 41) indica como brotaram tais ensaios: "meu pressuposto é que o próprio pensamento emerge de incidentes da experiência viva e a eles deve permanecer ligado, já que são os únicos marcos por onde pode obter orientação". Ora, segundo suas palavras - vale lembrar que, mantendo a metáfora, o autor/compositor é também o primeiro intérprete -, os dois movimentos iniciais da suíte sinalizam que o campo harmônico - o lugar da escuta - em que se desdobra o restante da suíte musical deve partir da "experiência viva e a eles permanecer ligado"; do contrário, desorienta-se. Que se escute a segunda parte:

A segunda discute dois conceitos políticos centrais e inter-relacionados autoridade e liberdade. Pressupõe a discussão da primeira parte, porquanto questões elementares e diretas como: O que é autoridade? O que é liberdade?, só podem surgir quando não mais se dispõe de respostas deixadas pela tradição e ainda válidas (ARENDT, 1992, p. 42, grifos nossos).

O leitor-ouvinte é aqui informado sobre um pré-requisito para a percepçãocompreensão da suíte. É claro que ele é livre para ler-ouvir a segunda parte, composta de dois movimentos também autônomos e relacionados entre si - $O$ que é autoridade? e $O$ que é liberdade? -, sem que antes tenha fruído da primeira. Mas a autora sugere expressamente que ele comece sua leitura-audição pela primeira parte e só então passe à segunda. Assim, a própria condição de existência dos movimentos centrais - em termos musicais, estaríamos no âmbito da harmonia - não pode prescindir da primeira parte, pois é nela que se definem os limites do campo harmônico da suíte como um todo. Em outras palavras, "só podem existir [os dois ensaios centrais sobre liberdade e autoridade] quando não mais se dispõe de respostas deixadas pela tradição e ainda válidas". 
Em resumo: o questionamento sobre o significado da liberdade e da autoridade - os dois movimentos centrais da suíte - só pode existir porque a tradição se rompeu, isto é, as categorias com que se pensam e julgam as coisas do mundo - tema da primeira parte da suíte - perderam a validade. ${ }^{1}$ Estivessem em vigência as regras de composição ditas tradicionais (o cânone), os movimentos centrais da suíte seriam outros, jamais uma reflexão sobre os fundamentos da liberdade e da autoridade políticas. O que legitima a pergunta sobre o significado da liberdade e da autoridade é o fato de que, se o pensamento emerge "de incidentes da experiência viva e a eles deve permanecer ligado", a experiência mostrou que tanto uma quanto outra tiveram seu significado obscurecido. Numa linguagem ainda metafórica, porém, o leitor pode recuar um pouco:

[...] há um componente experimental na interpretação crítica do passado, cujo alvo principal é descobrir as verdadeiras origens de conceitos tradicionais, a fim de destilar deles sua primitiva essência, que tão melancolicamente evadiu-se das próprias palavras-chave da linguagem política [...] deixando atrás de si formas ocas com as quais se dão quase todas as explicações, à revelia da subjacente realidade fenomênica (ARENDT, 1992, p. 41, grifo meu).

Assim, a primeira parte da suíte revela as condições em que se formaram a criação e a escuta musical, ou seja, o âmbito de nossas percepções, de nossos conceitos e juízos para fruir o belo. Ocorre que um novo evento musical - talvez se possa dizer um tremendo ruído: o totalitarismo - produziu uma ruptura nos princípios, nas leis e nas regras, de maneira que tais princípios, regras e leis musicais - leia-se: da compreensão e do juízo políticos - de que até então se dispunha, seja para compor (agir, atuar), seja para ouvir (fruir, espectar), perderam a validade com as transformações da era moderna. Supõe-se que para uma nova regra de composição (harmonia, narrativa histórica) exista uma nova forma de escuta; do contrário, o novo evento (o totalitarismo) corre o risco de ser percebido "à revelia da subjacente realidade fenomênica", isto é, sob as regras da velha tradição, da velha escuta, como um ruído inaudito e irreconhecível.

Agora que já está minimamente familiarizado com o novo evento musical, o ouvinte tem condições de prosseguir sua escuta da suíte e passar à terceira parte, composta de outros dois movimentos. Em relação a estes, diz a autora:

\footnotetext{
${ }^{1}$ No primeiro parágrafo do ensaio $O$ que é autoridade?, Arendt (1992, p. 127) esclarece: "Para evitar malentendidos, teria sido muito mais prudente indagar no título: $\mathrm{O}$ que foi - e não o que é - autoridade? Pois meu argumento é que somos tentados a levantar essa questão por ter a autoridade desaparecido do mundo moderno".
} 
Os [...] ensaios da última parte, por fim, são francas tentativas de aplicar o tipo de pensamento que foi posto à prova nas duas primeiras partes a problemas imediatos e correntes com o que nos defrontamos no dia-a-dia, não, decerto, com o fito de encontrar soluções categóricas, mas na esperança de esclarecer as questões e de adquirir alguma desenvoltura no confronto com problemas específicos (ARENDT, 1992, p. 42).

Insistindo na metáfora, temos que a última parte da suíte - os ensaios $A$ crise na educação e A crise na cultura - não mais se propõe a resolver os problemas das regras de composição que conformaram nossa audição, tema da primeira parte da suíte. Já que aquele âmbito harmônico que nos habilitava a compor foi implodido, resta-nos criar ou praticar alguns exercícios de percepção-escuta. Porém, há aqui um detalhe da mais alta importância: antes que a tradição de nossa escuta se rompesse, é lícito imaginar que esses exercícios de percepção se conformassem com aquelas regras de composição amplamente reconhecidas antes da ruptura. Tais exercícios não passavam de aplicações que, até onde podemos imaginar, confirmassem aquela tradição de onde brotaram.

Ocorre que agora o desafio é compor/fruir sem uma tradição que possa legitimar esta ou aquela suíte ou exercício de composição/fruição. O fato de que perdemos o fio - ou o tom - que nos guiava, ou bem orientava nossa ação/recepção, não significa em absoluto que não se possa mais compor ou fruir, pois, como a tradição não é todo o passado, poderia ser "que somente agora o passado se abrisse a nós com inesperada novidade e nos dissesse coisas que ninguém teve ainda ouvidos para ouvir" (ARENDT, 1992, p. 130). Afinal, os instrumentos continuam a existir e podemos com eles produzir os sons. Se, contudo, não mais existe um cânone que conforme as regras de composição, evitando que o resultado soe caótico aos ouvintes, como fica aquele que se sente impelido a compor/ouvir? Não poderia ele abrir seus ouvidos aos sons do universo antes de produzir por si próprio qualquer melodia? Afinal, antes que a variedade de sons preenchesse as linhas de um pentagrama, não estavam todos contidos naquela explosão original da qual se formaram ou, ainda que só em potência, naquele sopro divino que insuflou o primeiro homem? Ao se abrir à nova realidade sonora do mundo e ser tomado pelo desejo de compreendê-lo, ele não poderia começar a se exercitar como que tentando identificá-los, antes que tentasse capturá-los e, assim, "adquirir alguma desenvoltura no confronto" com essas novas sonoridades?

Enfim, a metáfora musical talvez não seja mero ornamento do prefácio de Entre $o$ passado e o futuro, pois, no primeiro movimento da suíte política $A$ tradição e a época moderna, novamente o leitor/ouvinte se depara com ela: 
O início e o fim da tradição têm em comum o seguinte: os problemas elementares da Política jamais vêm tão claramente à luz, em sua urgência imediata e simples, como ao serem formulados pela primeira vez, e ao receberem seu desafio final. O início, nas palavras de Jacob Burckhardt, é como um "acorde fundamental", que ressoa em infindáveis modulações através de toda a história do pensamento ocidental. Somente o início e o fim são, por assim dizer, puros ou sem modulação; e o acorde fundamental, portanto, jamais atinge seus ouvintes com maior força e beleza do que ao enviar pela primeira vez seu som harmonizador ao mundo, e nunca de forma irritante e dissonante que ao continuar a ser ouvido em um mundo cujos sons - e pensamento - não pode mais harmonizar (ARENDT, 1992, p. 44).

O programa de Hannah Arendt talvez aí se deixe entrever por inteiro ou quase. O acorde fundamental - convém lembrar que se trata de uma tríade - certamente é uma questão em aberto para aqueles que desejam extrapolar o sentido da metáfora musical. Aqui, sugiro que a tônica - nota da tríade que dá nome ao acorde fundamental - também sofre modulações ao longo da obra de Arendt: ora está na tradição oculta do judaísmo e na questão do antissemitismo moderno; por vezes, na tradição homérica, nos historiadores antigos e nos poetas trágicos; por fim, a tônica do acorde fundamental pode estar em sua interpretação da filosofia política (não escrita) de Kant. Cronologicamente, inclusive, o primeiro grande tema político de Arendt não foi o diálogo que travou com a Antiguidade greco-romana, marco inicial da tradição política do Ocidente e que a partir de então vai ressoar "em infindáveis modulações através de toda a história do pensamento ocidental”. Mas a questão judaica. Seja como for, tais modulações se constituirão num problema a meditar, uma vez que vão se afastar de tal forma daquela "força e beleza" que já não poderão harmonizar o diálogo mundoouvinte. Irritante e dissonante, o mundo que experimentou o terror totalitário levou o ouvinte à surdez e à mudez e reclama um pensamento que tome para si a responsabilidade de harmonizá-lo outra vez - pensamento e mundo reconciliados, a fim de que seja possível a beleza do início, do sentir-se novamente em casa no mundo.

A metáfora musical impele a retomar a distinção que Arendt propõe entre artes criativas, como a poesia, a escultura e a literatura, e artes de desempenho, como o teatro, a dança e a música. Das primeiras se frui sem a presença dos autores, ao passo que só se pode fruir das últimas por meio de atores e intérpretes:

As artes de desempenho [performing arts] [...] têm como efeito uma grande afinidade com a política. Os artistas executantes - dançarinos, atores, músicos e o que o valha - precisam de uma audiência para mostrarem seu virtuosismo, do mesmo modo como os homens que agem necessitam da presença de outros ante os quais possam aparecer, ambos requerem um espaço publicamente organizado para sua "obra", e ambos dependem de 
outros para o desempenho de si (ARENDT, 1992, p. 200, tradução modificada).

A perda desse âmbito, desse "espaço publicamente organizado" onde homens e mulheres se inserem como atores e espectadores do mundo, é o que move a reflexão de Hannah Arendt, um exercício capaz de incitar a dignidade da política. A metáfora da suíte se mostra fecunda para a análise que aqui se vai empreender não apenas por permitir lançar mão de alguns termos retirados do estrito contexto musicológico, como a polifonia, a dissonância e o acorde fundamental, mas sobretudo porque esta pesquisa tem profunda afinidade com a ideia de polifonia que está presente em uma suíte. O parentesco formal com o prefácio de Entre o passado e o futuro, antes de representar uma simples afinidade, também revela o caráter desta pesquisa, assim como seus limites.

Ao reunir temas tão distintos como educação, política e história à luz do pensamento de Hannah Arendt, a tese incorre no risco de fragmentar o foco de sua discussão, risco este que se espera compensado pelo diálogo proporcionado por uma análise interdisciplinar, ainda que num tom mais ensaístico. Agora que o trabalho se mostra por inteiro à contemplação, fica evidente que ele escapou da exegese de uma questão clara e distinta normalmente requerida numa tese. Seja como for, e ainda que de modo nem sempre explícito, cada capítulo busca agregar elementos para se pensar o sentido formativo da História. 


\section{O exílio da narrativa e a narrativa do exílio}

Me parece que ninguno de nosotros puede regresar (y escribir es una forma de regresar) solo porque parezca que están dispuestos a reconocer otra vez a los alemanes como alemanes, o lo que sea; sólo

podríamos regresar si fuésemos bienvenidos como judíos. Esto significa que yo escribiría con mucho gusto si pudiera escribir como judía acerca de cualquier aspecto de la cuestión judía.

(Carta de Arendt a Jaspers, 29 de janeiro de 1946)

\subsection{O ator, o espectador e a faculdade do juízo: primeira aproximação}

A obra póstuma A vida do espírito, publicada em 1978, foi organizada por Mary McCarthy, escritora e amiga de Hannah Arendt. Concebida num tríptico - a exemplo da tríade trabalho, obra e ação em A condição humana -, abordaria as principais faculdades da vida do espírito: o pensar, o querer e o julgar. Arendt, que morreu em dezembro de 1975, não chegou a iniciar a terceira parte da obra: o julgar, mas já havia utilizado "material sobre o juízo em cursos sobre a filosofia política de Kant que lecionou na Universidade de Chicago e na New School" (McCARTHY, 2000, p. 240). Assim, McCarthy preparou excertos desse material e os incluiu como apêndice de $A$ vida do espírito, acrescentando também um posfácio. Posteriormente, em 1982, Ronald Beiner organizou e publicou Lectures on Kant's political philosophy (Lições sobre a filosofia política de Kant), proferidas por Arendt no outono de 1970 na New School for Social Research, juntamente com um ensaio no qual postula que as Lições "são uma base razoável para reconstruir a teoria do julgar de Hannah Arendt" (BEINER, 1993, p. 87).

Na introdução à Crítica da faculdade do juízo, de 1790, Kant distingue duas modalidades do julgar. Diz ele:

A faculdade do juízo em geral é a faculdade de pensar o particular como contido no universal. No caso de este (a regra, o princípio, a lei) ser dado, a faculdade do juízo, que nele subsume o particular, é determinante [...]. Porém, se só o particular for dado, para o qual ela deve encontrar o universal, então a faculdade do juízo é simplesmente reflexiva (KANT, 2010, p. 23, grifo nosso).

O interesse de Arendt por essa obra, especialmente no que diz respeito às considerações de Kant sobre o juízo reflexivo, desdobra-se em vários aspectos, tal como ela 
revela numa carta a Jaspers. ${ }^{2}$ Mas há um ponto que, para os propósitos deste trabalho, é essencial no que concerne à faculdade de julgar. Arendt (1993a, p. 41, grifo nosso) pondera:

Não é porque alguma "idéia" nova veio ao mundo que a originalidade do totalitarismo é terrível, mas sim porque as próprias ações desse movimento constituem uma ruptura com todas as nossas tradições; elas claramente destruíram as categorias de nosso pensamento político e nossos padrões de juízo moral.

Ora, se "as próprias ações" dos regimes totalitários "destruíram as categorias de nosso pensamento político e nossos padrões de juízo moral”, esses regimes desafiam a compreensão do homem de ação e do pensador, pois não é possível ajuizá-los em sua particularidade - e aqui talvez seja irrelevante saber se esse juízo se dá na perspectiva do ator político ou do espectador -, subsumindo-os a uma regra previamente dada, isto é, a um juízo determinante, ou apelando a conceitos como os de despotismo, tirania, autoritarismo ou outras categorias legadas pela tradição. Para Arendt, a experiência totalitária é um fenômeno sem precedentes e, portanto, demanda um tipo de compreensão que, se não pode prescindir da tradição, também não se deixa reduzir às formas que esta consagrou ao entendimento e ao juízo. $\mathrm{O}$ papel do narrador, nesse caso, implica o desafio de fazer aflorar o sentido de um evento em sua irredutível particularidade.

Ocorre que, segundo a moderna consciência historiográfica, todo acontecimento particular é parte de um processo mais amplo - estrutural, se dirá - em que os acontecimentos se diluem, o que sacrifica a inteligibilidade que, de acordo com Arendt, só a particularidade do acontecimento revela. Como se valer, então, da moderna consciência historiográfica diante de um evento sem precedentes como o totalitarismo? Isso implica que o totalitarismo representa também um problema epistemológico, pois reclama um juízo que o legado da tradição não é capaz de orientar.

Os ensaios produzidos por Arendt ao longo dos anos 1940 exemplificam bem sua tentativa de exercitar um tipo de compreensão e de juízo distintos, por se debruçar sobre acontecimentos particulares sem a pretensão de abarcá-los numa visão totalizante. Ao contrário, Arendt faz da própria contingência e do caráter por vezes inusitado dos fenômenos

\footnotetext{
2 "Actualmente leo con entusiasmo creciente la Crítica del Juicio. Ahí se esconde la verdadera filosofía política de Kant, y no en la Crítica de la razón práctica. La alabanza del tan denostado 'sentido común', el tomarse filosóficamente en serio el fenómeno del gusto como fenómeno fundamental de la facultad de juzgar (presumiblemente lo es en todas las aristocracias), ese 'modo de pensar ampliado' (que forma parte del juicio), según el cual uno puede pensar en el lugar de todos los demás. La exigencia de comunicabilidad. Ahí están las experiencias que hizo el joven Kant en su sociedad, revitalizadas nuevamente por el Kant anciano" (ARENDT, 2010b, p. 139).
} 
que analisa a oportunidade de buscar um sentido neles e por meio deles. Birulés (2007, p. 186, grifos nossos) sugere que

[...] el pensamiento de Arendt estaría en total sintonía con la idea de que el historiador elabora constantemente juicios históricos y de que el trabajo de historiar no acaba nunca, no hay en ella profesión de relativismo alguna, sino un gesto de reconocer el carácter inestable y provisional de la verdad histórica.

A guerra está em curso; a história, em aberto. As análises que Arendt produz nesse período do exílio (1933-1951) carregam a marca da contingência, reconhecem o caráter instável e provisório dos juízos históricos. Quero sugerir que antes de confrontar-se com o caso Eichmann, no início dos anos 1960 - e boa parte da crítica vê em Eichmann em Jerusalém, de 1963, um ponto de inflexão de seu pensamento, uma virada que se desdobra de uma ampla consideração sobre as atividades da chamada vida ativa (o trabalho, a obra/fabricação e a ação) para preocupações relativas ao âmbito da vida do espírito -, e igualmente antes de se ocupar teoricamente com a faculdade de julgar, Arendt já exercitava um juízo reflexivo na dupla modalidade de ator e espectador desde que se viu impelida a exilar-se da Alemanha em 1933.

Visto dessa perspectiva, o exílio da narrativa sugere um problema epistemológico que remete às dificuldades de compreensão de um fenômeno histórico sem precedentes. A narrativa se exila quando a linguagem e as categorias que herdamos para contar histórias tornam-se incapazes de narrar e julgar o ocorrido. Anos depois dos ensaios da década de 1940, Arendt resumiria essa dificuldade num belíssimo aforismo do poeta francês René Char: "Nossa herança nos foi deixada sem nenhum testamento" (apud ARENDT, 1992, p. 28). A primeira reação ao silêncio de Auschwitz é o exílio da narrativa, conforme Arendt (1993a, p. 134-5) revela a Gaus: "o decisivo para nós foi o dia em que ouvimos falar de Auschwitz. [...] isso jamais poderia ter acontecido. Lá se produziu alguma coisa que nunca chegamos a assimilar”. As fábricas de extermínio reduzem toda experiência à mudez, pois corroem a essência da transmissibilidade e do sentido legado de uma geração à outra. Em contrapartida, o gesto de não se curvar ao emudecimento é a narrativa do exílio: uma tentativa de compreender e narrar o fenômeno totalitário a fim de reconciliar os homens num mundo em que tal fenômeno foi possível. Ludz (2010, p. 23, grifos nossos) observa:

La narración ilustra un aspecto ulterior de la comprensión [...]. Lo importante, por tanto, no es sólo la comprensión, sino también el hecho de ser comprendido, el hecho de que través de la comprensión se establece el contacto con otras personas. $\mathrm{Y}$ precisamente este aspecto se da más 
nítidamente en el contexto narrativo que en la comprensión. Por lo general, uno no se cuenta una historia a sí mismo, sino a otras personas, para comunicar sentido. Y en la medida en que esto se logra decimos que somos comprendidos por los otros, y el narrador se torna tanto más "real" y más "vivo".

A importância de ressaltar tal contexto narrativo é que, apesar da valiosa contribuição do ensaio de Ronald Beiner ${ }^{3}$ no sentido de propor uma interpretação para as conferências que Arendt deu sobre o juízo, poucos intérpretes aproximam juízo e narrativa. É isso o que aqui se buscará. Far-se-á um breve resumo do ensaio de Beiner, menos com o propósito de contestálo, e mais com a intenção de sinalizar a diferença almejada. Ao final, o tema compreensãonarrativa-juízo e a diferença que aqui se busca retornarão. Note-se que, ao longo deste trabalho, o juízo é sempre abordado como reflexivo, quando aquele que julga (ator ou espectador) não dispõe da regra, lei ou principio para aplicar, isto é, subsumir um caso particular.

O problema da interpretação de Beiner sobre o juízo é que ela cinde a reflexão de Arendt em dois planos: uma cisão que ele atribui à própria Arendt quando distingue o juízo do ator e o do espectador, isto é, o juízo referido aos homens de ação e aquele juízo retrospectivo, após os fatos, que é próprio dos historiadores. Para Arendt, quando um ator julga, porque envolvido diretamente na ação política, ele não é capaz de perceber o sentido geral da trama em que se envolve, já que está comprometido com parte da ação. Ao desempenhar sua ação, ele busca ser visto e julgado pelo espectador. Resumidamente, busca a glória por uma ação valorosa, o desempenho de uma virtude (aretê): a coragem, a prudência, a astúcia, enfim. Busca igualmente a fama, que para os gregos também significa opinião (doxa): a opinião do espectador. Daí a parcialidade inerente ao juízo do ator político.

Em contrapartida, o juízo do espectador supõe o não envolvimento direto na trama, porque implica distância. Seu interesse é antes contemplativo. Assim, além de estar em melhor condição para captar o sentido geral da trama, o espectador é o mais indicado para almejar a imparcialidade do julgamento, pois o que o move não é um interesse pessoal nos resultados da ação, mas o prazer no julgar em si mesmo. Kant o chamava de prazer

\footnotetext{
${ }^{3}$ Sobre a apropriação do juízo reflexivo kantiano por parte de Hannah Arendt, convém lembrar esta advertência geral de Cassirer: "A história da filosofia mostra-nos com muita clareza que muito raramente a plena determinação de um conceito é obra do pensador que o introduziu pela primeira vez. Isto porque, de maneira geral, um conceito filosófico é antes um problema que a solução de um problema - e o pleno significado desse problema não pode ser entendido enquanto ele permanecer em seu primeiro estado implícito. Ele deve tornar-se explícito para poder ser entendido em seu verdadeiro sentido, e essa transição de um estado implícito para o explícito é obra do futuro" (CASSIRER, 1997, p. 294).
} 
desinteressado e Arendt o aproxima da imparcialidade. ${ }^{4}$ Tal interpretação - aqui resumida apenas para esclarecer uma hipótese - cria profundas dificuldades quando se intenta compreender não tanto uma teoria do juízo em Hannah Arendt e sua relevância política - seja a partir de sua heterodoxa leitura de Kant ou mesmo da phronesis (prudência) aristotélica -, mas algo distinto: o que significa tomar o próprio conjunto da obra de Arendt como um notável exercício da faculdade de julgar acontecimentos particulares enquanto particulares? Arendt (1993a, p. 49) sublinha: "O novo é o domínio do historiador que, ao contrário do cientista natural, preocupado com acontecimentos sempre recorrentes, lida com eventos que sempre ocorrem somente uma vez". Esse evento iluminador - porque particular, único -, é o que interessa a Arendt compreender, e não a história como o lugar de um processo em direção ao progresso da humanidade.

Arendt recusa a ideia de uma força invisível ou transcendente que operaria por trás dos homens, como o ardil da natureza, em Kant, ou mesmo o intento de vislumbrar retrospectivamente a manifestação da história por meio da astúcia da razão ou do espírito absoluto, como em Hegel. O interesse de Arendt pela história está em vê-la como palco das realizações humanas em suas particularidades - dado o caráter sem precedentes do totalitarismo. Para ela, os regimes totalitários colocaram à prova toda e qualquer filosofia da história em seus variados matizes, uma vez que representaram uma derrota do projeto iluminista de emancipação do homem e da crença no progresso.

A análise histórica como um exercício do julgar, no sentido de tomada de uma posição política, é uma prerrogativa tanto daquele que se impele à ação quanto daquele que se coloca como espectador da ação, de modo que o espectador e o ator não são duas entidades, mas duas condições do ato de julgar. Arendt antecipa, ao final do volume Pensar de A vida do espírito (Postscriptum), algumas questões e dificuldades que vislumbra para a execução dos volumes sobre o Querer e o Julgar. Sobre este último, sublinha:

Aqui teremos de nos ocupar, e não pela primeira vez, do conceito de história.
[...] Se o juízo é a nossa faculdade para lidar com o passado, o historiador é
o homem que indaga sobre esse passado e que, ao relatá-lo, preside ao seu
julgamento. Se assim for, poderemos reclamar para nós nossa dignidade
humana, resgatá-la, por assim dizer, da pseudo-divindade chamada História
na Era Moderna, sem negar a importância da história, mas negando-lhe o
direito de ser o último juiz (ARENDT, 1999, p. 239 , grifo nosso).

“Aqui teremos de nos ocupar, e não pela primeira vez, do conceito de história”. De fato, não foi a primeira vez que Arendt se ocupou com tal conceito, tanto quanto com a

\footnotetext{
${ }^{4}$ Cf. ARENDT, 1993b, p. 88.
} 
particularidade dos acontecimentos históricos. A questão que aqui se ressalta é se um acontecimento sem precedentes como as deportações para as fábricas de extermínio pode ser apanhado ou dominado por um conceito, ou subsumido a uma regra, uma lei ou um princípio. Para Arendt, é justamente o caráter inédito da experiência totalitária, isto é, as ações daqueles movimentos, que fez implodir a tradição do pensamento e os critérios de juízo até então aceitos. 5

O fato é que a parcialidade do juízo do ator político não é algo que o diminua em absoluto. Essa parcialidade apenas se inscreve num momento específico de um homem de ação que não pode pretender, ao menos naquele momento, nem uma visão de conjunto de todos os atores envolvidos naquelas ações, nem uma previsão de seus resultados. De acordo com Arendt, as ações se caracterizam pela irreversibilidade e pela imprevisibilidade. ${ }^{6}$ Ao ator político, porém, também é dada a oportunidade posterior da distância e, então, de almejar um julgamento imparcial. Hannah Arendt historiadora? A questão não admite resposta imediata. Ao longo deste trabalho será possível ir somando elementos e retomá-la ao final. Ao mestre e amigo Jaspers, entretanto, em carta de 18 de novembro de 1945, Arendt (2010b, p. 120) confia: "Desde que estoy en América, es decir, desde 1941, me he convertido en una especie de autora independiente, algo intermedio entre el historiador y el publicista político".

Hobsbawm, que, como Arendt, viveu o extremado século XX, gostava de dizer que era um historiador do século XIX, mas deixou um testemunho do século que lhe tocou viver. Ao menos quando analisa o século XX, parece que ele e Arendt concordariam em alguns pontos. Em suas palavras:

A principal tarefa do historiador não é julgar, mas compreender, mesmo o que temos mais dificuldade para compreender. $O$ que dificulta a compreensão, no entanto, não são apenas nossas convicções apaixonadas, mas também a experiência histórica que as formou. As primeiras são fáceis de superar, pois não há verdade no conhecido dito francês tout comprendre c'est tout pardonner ${ }^{7}$ (tudo compreender é tudo perdoar). Compreender a era nazista na história alemã e enquadrá-la em seu contexto histórico não é

\footnotetext{
${ }^{5} \mathrm{Na}$ abertura de sua obra, Tucídides não utiliza a categoria sem precedentes como faz Arendt. Mas não deixa de acentuar o ineditismo dos eventos que irão compor sua narrativa: "O ateniense Tucídides escreveu a história da guerra entre os peloponésios e os atenienses [...] na expectativa de que ela seria grande e mais importante que todas as anteriores. [...] Com efeito, tratava-se do maior movimento jamais realizado pelos helenos, estendendose também a alguns povos bárbaros - a bem dizer a maior parte da humanidade. Na verdade, quanto aos eventos anteriores [...] penso que eles não foram realmente grandes" (TUCÍDIDES, 1982, p. 19, grifo nosso).

${ }^{6} \mathrm{O}$ tema ocupa a reflexão de Arendt nas duas seções finais do capítulo dedicado à ação em $A$ condição humana: a seção 33, intitulada $A$ irreversibilidade e o poder de perdoar, e a seção 34, intitulada $A$ imprevisibilidade $e$ o poder de prometer.

${ }^{7}$ Em seu ensaio Compreensão e política, de 1953, Arendt (1993a, p. 39) afirma: “O fato de que a reconciliação é inerente à compreensão deu origem à idéia distorcida e popular de que tout comprendre c'est tout pardonner. Perdoar, no entanto, tem tão pouco a ver com compreender, que não é sua condição nem sua consequiência".
} 
perdoar o genocídio. De toda forma, não é provável que uma pessoa que tenha vivido este século extraordinário se abstenha de julgar. $O$ difícil é compreender (HOBSBAWM, 1995, p. 15, grifo nosso).

Ora, a solução final (o extermínio em massa nos campos de concentração) coloca em questão um problema que ultrapassa as dificuldades costumeiras de uma narrativa, já que, para Arendt, o ato de narrar também implica a busca de uma reconciliação com o mundo. A solução final significou uma tentativa de eliminar da face da terra a pluralidade humana, daí porque esse crime, na perspectiva de Arendt, não foi praticado apenas contra a comunidade judaica e outras minorias (étnicas ou não) - suas maiores vítimas -, mas consistiu em um crime contra a humanidade. As fábricas de extermínio impõem um desafio à compreensão e aos critérios de julgamento, pois revelam que a doutrina dos direitos humanos nascida na Revolução Francesa pouco ou nada servia quando essas minorias não estavam sob a proteção de um Estado-nação. ${ }^{8}$ De acordo com Arendt, o princípio segundo o qual os direitos humanos são inalienáveis caíra por terra.

Como Arendt sublinha em muitas passagens de sua obra, o sentido de uma história só vem à luz quando ela chega ao fim e pode ser narrada. ${ }^{9}$ Assim, como primeira aproximação do exílio da narrativa, far-se-á um breve exame do significado político que ela foi construindo para a judeidade diante do modo como os regimes totalitários trataram suas vítimas, expulsando-as da humanidade ao sujeitarem-nas a uma forma de poder sem limites e sem precedentes. ${ }^{10}$ Para tanto, vai se recorrer primordialmente a ensaios que cobrem o período de exílio (1933-1951), marcados pela temática da judeidade e prévios à publicação de Origens do totalitarismo, em 1951.

\footnotetext{
${ }^{8}$ A esse tema Arendt consagrou um capítulo de Origens do totalitarismo, intitulado O declínio do Estado-nação e o fim dos direitos do homem, que foi objeto de estudo de Celso Lafer. O autor mostra a pertinência da análise de Arendt sobre os direitos humanos, especialmente quanto ao significado da expressão por ela cunhada acerca do direito a ter direitos. Para ele, o totalitarismo revelou a "erosão do paradigma do Direito Natural" e "à perda do status civitatis de centenas de milhares de pessoas. Isto afetou o estado e a capacidade destas pessoas, que se viram postas fora da lei na medida em que não tinham posição jurídica caracterizada no seio da coletividade, perdendo, por isso mesmo, o seu modo particular de existir juridicamente" (LAFER, 1988, p. 81; 109).

${ }^{9}$ No ensaio sobre Lessing, por exemplo: "o sentido de um acto praticado só se revela quando a ação em si chegou ao fim, convertendo-se numa história suscetível de ser narrada" (ARENDT, 1991, p. 32).

${ }^{10}$ Benhabib (2007, p. 60) sublinha: "El poder totalitario consiste en hacer superfluos a los seres humanos; esto es, hacerlos sujetos a formas de poder que no conocen límites. En este sentido, los campos de concentración del nazismo o el Gulag del estalinismo son la manifestación concreta de una novedosa forma de poder político que pretende una total dominación y la destrucción de la capacidad independiente para actuar del ser humano."
} 
Na apresentação à tradução espanhola da obra póstuma The Jew as Pariah: Jewish identity and politics in the Modern Age (1978), ${ }^{11}$ Birulés (2005a, p. XII-XIII, grifo nosso) pondera:

[...] atender a lo que indica esta respuesta [sou uma judia] puede proporcionar algunas pistas no sólo relativas a su postura con la "cuestión judía" sino también, y muy especialmente, a su tratamiento de la acción, de la natalidad y del espacio público caracterizado por su irreducible pluralidad.

O que vem a seguir é uma tentativa de ir ao encontro de tais pistas. Para tanto, convém perceber como Arendt se apropria da judeidade. Tal procedimento contribui para esclarecer o lugar que ela reserva à narrativa em seu pensamento político e que faz de Origens do totalitarismo um ato de restituir à narrativa histórica duas dimensões fundamentais da condição humana: a pluralidade e a memória, ambas negadas pelos regimes totalitários.

\subsection{A narrativa como regresso (1933-1951)}

Parte considerável da produção de Hannah Arendt que cobre o período aqui tratado está reunida em quatro obras, duas delas póstumas: Rahel Varnhagen: the life of a Jewess, de 1958; ${ }^{12}$ Sechs essays, de 1948; ${ }^{13}$ The Jew as Pariah: Jewish identity and politics in the Modern Age, de 1978; e Essays in understanding, 1930-1954, de 1994. ${ }^{14}$ Aqui, trata-se de estabelecer uma primeira aproximação ao problema. E ela se inicia por um dado que Arendt não escolheu - e a ninguém é dado escolher -, mas que, ante a história por ela vivida, tornouse uma questão política incontornável: Arendt é uma apátrida, exatamente por ser judia. ${ }^{15}$ Parece mesmo impossível não ver nessa contingência uma relação com fatos de longa duração: o que significa moldar uma consciência histórica a partir da experiência do exílio

\footnotetext{
${ }^{11}$ Organizada por R. H. Feldman. Seguimos a edição em espanhol: Una revisión de la historia judia y otros ensayos (ARENDT, 2005b).

${ }^{12}$ Originalmente escrita em alemão, a obra foi traduzida por Richard Winston e Clare Winston e publicada por uma editora londrina para o Instituto Leo Baeck, em 1958. Seguimos a edição em português: Rahel Varnhagen: a vida de uma judia alemã na época do romantismo (ARENDT, 1994).

${ }^{13}$ Seguimos a edição em espanhol: La tradición oculta (ARENDT, 2004a).

${ }^{14}$ Obra póstuma organizada por J. Cohn. Seguimos a edição em português: Compreender: formação, exílio e totalitarismo (ensaios) (ARENDT, 2008b).

15 "O caso dos apátridas, o ponto cego dos direitos humanos ditos naturais, não é, entretanto, o de quem não se decidiu a agir, mas o de quem não pode agir, afirmar, junto a seus pares, o mundo e uma parte específica dele como a sua casa" (CORREIA, 2010b, p. 814).
} 
para uma judia e apátrida como Arendt? ${ }^{16}$ A correspondência entre Arendt e Jaspers ao longo do período em pauta joga luz na questão.

Hannah Arendt e seu antigo mestre Karl Jaspers se encontraram pela última vez em 1938, ano em que a correspondência entre eles é interrompida. Em 1945, findada a guerra, ambos desconhecem o paradeiro um do outro. Sequer sabem se estão vivos. Até que Melvin Lasky, correspondente da Partisan Review alocado na Alemanha, é incumbido de publicar uma entrevista com Jaspers. A certa altura, Lasky alude ao nome Hannah Arendt. Atônito, Jaspers pergunta ao correspondente se ele faria chegar a Arendt uma carta sua e de sua mulher, Gertrud, por meio do correio militar norte-americano. ${ }^{17}$ Em setembro de 1945, a carta é enviada e a correspondência entre eles é retomada.

Dois meses depois, Jaspers envia a Arendt o primeiro número de uma nova publicação, Die Wandlung, ${ }^{18}$ e na carta que acompanha o exemplar ele a consulta sobre a possibilidade de ela contribuir com um ensaio para a revista. Ela consente e, em abril de 1946, o ensaio Organisierte schuld (Culpa organizada) é publicado, sendo o primeiro de uma série de outros. Em 1948, sai na Alemanha Sechs essays, ${ }^{19}$ uma compilação dos ensaios que Arendt publicou em Die Wandlung, encabeçados por uma dedicatória ao seu antigo mestre.

$\mathrm{Na}$ resposta à carta-convite de novembro de 1945, Arendt, que estava nos Estados Unidos desde 1941, revela a alegria em escrever para a nova revista, mas partilha com Jaspers certo desconforto em colaborar com uma publicação europeia. Expõe suas razões e pede ao mestre que não a interprete mal. A primeira razão diz respeito ao abandono da Europa por parte dos judeus (ela evoca a situação dos campos de refugiados, ${ }^{20}$ dentro e fora da Alemanha); a segunda refere-se aos temores de Arendt quanto à possibilidade de uma nova catástrofe, especialmente na Palestina; ${ }^{21}$ por fim, opina que, no caso de os judeus permanecerem na Europa, que não o fizessem como se fossem alemães ou franceses, evitando o tema do judaísmo como se nada lhes tivesse ocorrido. Sobre este último ponto, insiste:

\footnotetext{
${ }^{16}$ Sobre essa moldura da consciência histórica para a geração de judeus expatriados como Arendt, ver BOURETZ, 2011, p. 14 e ss.

${ }^{17}$ Cf. YOUNG-BRUEHL, 1997, p. 203.

${ }^{18}$ Die Wandlung foi criado por Jaspers e Dolf Sternberger (amigo de Hannah Arendt de Frankfurt) com a colaboração de Werner Krauss e Alfred Weber. O periódico durou quatro anos, de 1945 a 1949, e entre seus colaboradores se encontravam Hannah Arendt, Bertold Brecht, Thomas Mann, Martin Buber, Carl Zuchmayer, T. S. Eliot, W. H. Auden, J. P. Sartre e Albert Camus, entre outros (Cf. YOUNG-BRUEHL, 1997, p. 205-6).

${ }^{19}$ Em 1976, uma versão ligeiramente modificada de Sechs essays foi publicada na Alemanha sob o título de Die verborgene tradition: acht essays, base da tradução castelhana de 2004 que aqui se utilizou (La tradición oculta).

${ }^{20}$ O problema relacionado aos refugiados ocupa a reflexão de Arendt em 1943, quando ela publica o ensaio We refugees em The Menorah Journal (v. 31, n. 1, p. 69-77).

${ }^{21}$ A questão política que se colocava na Palestina ocupa Arendt nos ensaios Salvar la patria judía e Pazo armisticio en Oriente Próximo?, em Una revisión de la historia judía y otros ensayos.
} 
Me parece que ninguno de nosotros puede regresar (y escribir es una forma de regresar) solo porque parezca que están dispuestos a reconocer otra vez a los alemanes como alemanes, o lo que sea; sólo podríamos regresar si fuésemos bienvenidos como judíos. Esto significa que yo escribiría con mucho gusto si pudiera escribir como judía acerca de cualquier aspecto de la cuestión judía (ARENDT, 2010b, p. 178, grifos nossos).

A primeira acepção que o Dicionário Houaiss da Língua Portuguesa apresenta para regressar é: "voltar ao ponto de partida; retornar". Como exemplos de uso, fornece os seguintes: "regressar ao lar" e "ele não quer regressar". Infere-se, então, que "escrever é uma forma de regressar" ao ponto de partida, de retornar ao lar, isto é, à Alemanha. Uma primeira questão se impõe: mas qual Alemanha? Ao território alemão e, por extensão, à língua alemã, ou trata-se apenas de retornar à língua de Goethe, evitando o retorno ao território? $\mathrm{Na}$ dedicatória a Jaspers em Sechs essays, Arendt (2008b, p. 240, grifo nosso) toca na questão:

Pois hoje, para um judeu, não é fácil publicar na Alemanha, mesmo sendo
um judeu de língua alemã. Em face do ocorrido, a sedutora oportunidade de
voltar a escrever na língua materna conta muito pouco, embora seja o único
retorno ao lar do exílio que nunca conseguimos banir por completo dos
nossos sonhos [...] o fato da expulsão em si nos obrigou a olhar para a
nossa própria história, em que a expulsão aparece como um fenômeno não
único e invulgar, e sim familiar e repetido.

O apelo de Arendt parece expressar sua posição com respeito à situação política europeia $^{22}$ em relação aos judeus, fato que justificaria sua recusa em retornar ao território alemão, ao menos naquele momento. No início dos anos 1930, antes mesmo da ascensão dos nazistas ao poder, Arendt e Jaspers debateram por carta o problema da identidade alemã motivado pela publicação de um livro de Jaspers sobre Max Weber. Na ocasião, Arendt (2010b, p. 176) já teria dito: "Para mi, Alemania es la lengua materna, la filosofía y la poesía. De todo eso puedo e debo hacerme responsable" (carta de $1^{\circ}$ de janeiro de 1933).

Quando sublinha que os judeus só poderiam regressar se fossem bem-vindos é porque é inadmissível a Arendt que o regresso seja pago com a renúncia à judeidade, rendendo-se a qualquer convencionalismo social como modo de ocultar a identidade judaica. Esse tema já estava presente em suas reflexões sobre as armadilhas do assimilacionismo desde a biografia que escreveu sobre Rahel Varnhagen - praticamente concluída antes de partir para o exílio, em 1933 - e que atravessa vários de seus escritos judaicos reunidos em Sechs essays e The Jew as Pariah. Mas isso não esgota a questão. A crítica de Arendt ao assimilacionismo, assim

\footnotetext{
${ }^{22}$ Segundo Young-Bruehl (1997, p. 206), "Die Wandlung era um periódico europeu, não alemão; ele trazia a Europa para a Alemanha".
} 
como seu elogio à figura do pária consciente - conforme a expressão que toma emprestada do sionista e dreifusard Bernard Lazare ${ }^{23}$-, é parte de seu entendimento do que significa pertencer de fato a uma comunidade política, a um espaço público que garanta o direito de aparecer como se é, onde cidadãos possam revelar sua singularidade ao agir e fazer uso público da palavra.

Da mesma forma, a crítica ao assimilacionismo revela também um aspecto político caríssimo a Arendt, que é a pluralidade, o fato de que os homens vivem numa trama de relações que a um só tempo os une e separa e que, acima de tudo, deve acolher suas singularidades. Ora, como é possível a um judeu retornar à Europa se não é bem-vindo? Se aquele traço não eleito e que também conforma sua singularidade - ninguém elege nascer judeu, católico, muçulmano ou o que o valha - não é admitido no espaço público e, portanto, deve ser escondido? No fundo, Arendt está afirmando o dado incontroverso não apenas de sua judeidade, mas da judeidade constitutiva de todo e qualquer judeu. E reclama, em face das circunstâncias, o caráter político da judeidade.

O compromisso de Arendt é o de fazer emergir pontos de vista alternativos ao horror vivido pelos judeus. Ela se nega a submeter-se às conveniências, ao comportamento esperado socialmente. Nega-se a ocupar o lugar reservado pela sociedade europeia ao refugiado, que é o do silêncio ou da fala pública que vise a não constranger os outros com suas misérias, ou seja, uma tentativa de empurrar o refugiado para os confins da vida privada, da invisibilidade. Corajosa, Arendt toma a palavra. Parcial, à medida que reclama seu direito de ajuizar, adota uma perspectiva política, como revela a Jaspers:

[...] politicamente siempre hablaré sólo en nombre de los judios, en la medida en que las circunstancias me obliguen a indicar mi nacionalidad. Para mí es más fácil que para su esposa, [Gertrud Jaspers, uma judía como Arendt] porque estoy más alejada de todo eso, y porque nunca me he sentido espontánea o insistentemente "alemana". Lo que queda es la lengua, y una sólo llega a saber de verdad lo importante que es cuando habla y escribe en otras lenguas, más nolens que volens. ¿No basta con eso? (ARENDT, 2010b, p. 179, grifos nossos; carta de 17 de dezembro de 1946).

Note-se que o olhar de Arendt - e isso se manifesta em Origens do totalitarismo - tem a vantagem de um duplo distanciamento: o exílio e o fato de passar a escrever numa língua que não é sua língua natal. Ainda que alguns ensaios escritos em alemão sobre a questão judaica tenham sido aproveitados na primeira parte de Origens do totalitarismo (o Anti-

\footnotetext{
${ }^{23}$ Arendt trabalhou como editora para a Schocken Books e editou os escritos de Bernard Lazare, Job's dungheap (Nova York: Schocken Books, 1948).
} 
semitismo), a obra como um todo foi redigida em inglês. Nessa dupla distância, Arendt vai encarar o desafio de pensar por si mesma.

\title{
1.3. O desafio de pensar por si mesma
}

Qualquer tentativa de esmiuçar o pensamento político de Hannah Arendt esbarra no fato de que ela é uma judia e, "desde o início dos acontecimentos na Alemanha, [...] toma a palavra para testemunhar, enquanto judia, aquilo que se está a produzir debaixo dos seus olhos" (COURTINE-DÉNAMY, 1999, p. 39). A marca distintiva dessa condição parece não emergir com força antes que se confronte com a ascensão do regime nazista em 1933 e se torne uma ameaça a ela própria. Apenas quando o caráter subjetivo da condição judia se revela inadmissível na esfera pública da Alemanha nazista é que ele assume a dimensão política dessa identidade que não apenas foi rejeitada, mas banida do mundo público-político. Porém, antes que se consumasse a política nazista de perseguição aos judeus, era outra a percepção de Arendt, tal como revela numa entrevista a Günter Gaus concedida em 1964 ao canal 2 da TV alemã. Günter Gaus solicita que Arendt fale sobre o significado de ter vivido numa família de judeus assimilados na Alemanha do pré-guerra. Arendt (1993a, p. 128) comenta:

\begin{abstract}
A essa pergunta não posso dar uma resposta com valor de verdade geral. Mas no que diz respeito às minhas lembranças pessoais, não foi em casa que soube que era judia. Minha mãe era completamente alheia à religião. [...] a palavra "judeu" nunca era pronunciada entre nós, quando eu era menina. Foi por intermédio dos comentários anti-semitas das crianças da rua - que não valem a pena ser lembrados - que a palavra me foi pela primeira vez revelada. A partir desse momento é que fui, por assim dizer, "esclarecida".
\end{abstract}

Seus pais nutriam simpatias pelos socialistas e sua mãe Martha, admiradora de Rosa Luxemburgo, ${ }^{24}$ orientava a filha sobre como reagir diante de um comentário anti-semita na escola, dirigido ou não a ela. Se o comentário partisse de um professor, Arendt deveria retirarse imediatamente da sala de aula, voltar para casa e relatar à mãe, em detalhes, o que havia sucedido. Mas se a injuria partisse de alguma criança, Martha lhe dizia: “[...] não se deve abaixar a cabeça! É preciso defender-se!” (ARENDT, 1993a, p. 129). Salta aqui um aspecto crucial para as futuras reflexões políticas de Hannah Arendt em torno da judeidade e da política: se você é atacado como um judeu, deve defender-se sem negar essa condição. Nas

\footnotetext{
${ }^{24}$ Em 1966, Arendt faz uma resenha da biografia de Rosa Luxemburgo escrita por J. P. Nettl. Por ocasião da publicação de Homens em tempos sombrios (1968), ela reelabora o ensaio.
} 
palavras de Arendt (1991, p. 29), "só se pode resistir nos termos da identidade que é alvo de ataque".

Em julho de 1933 Arendt foi detida em Berlim pela Gestapo por colaborar com sionistas ligados a Kurt Blumenfeld, ${ }^{25}$ figura que ela admirava e a quem sempre se reconheceu devedora, intelectual e politicamente, por ter-lhe aberto os olhos para a questão judaica. ${ }^{26}$ Arendt havia sido incumbida pelos sionistas de reunir evidências sobre a ampla ação anti-semita em instituições da sociedade civil alemã. Após reunir extenso material, foi detida. Livre da prisão, mas não do processo movido contra ela por suas atividades políticas, parte para o exílio na França (1933-1941), onde desenvolve atividades ligadas às organizações judaicas que preparam jovens para um futuro na Palestina. Como sublinha Young-Bruehl (1997, p. 145), Arendt se tornou "sionista por razões políticas práticas [...] e não por razões religiosas ou culturais". Na entrevista a Gaus, Arendt (1993a, p. 126, grifo nosso) ainda recorda um fato que ilumina não apenas a assunção da judeidade, mas também a distinção entre ator e espectador:

Eu poderia falar em 27 de fevereiro de 1933, dia do incêndio do Reichstag e das prisões ilegais que a ele se seguiram, na mesma noite. Falava-se de "detenções preventivas": você sabe que na realidade as pessoas apodreciam nos porões da Gestapo ou nos campos de concentração. [...] Aquilo foi para mim um choque imediato, e a partir daquele momento me senti responsável. Isso significa que tomei consciência do fato de que não era mais possível contentar-se em ser espectador. Procurei agir por vários campos.

A tomada de consciência ecoa a célebre resposta dada por Kant $(1985$, p. 100) à pergunta sobre o que era o esclarecimento (Aufklärung): “[...] é a saída do homem de sua menoridade, da qual ele próprio é culpado. A menoridade é a incapacidade de fazer uso de seu entendimento sem a direção de outro indivíduo". Isso talvez explique as aspas no esclarecida da resposta dada a Gaus, quando se referia à descoberta de sua judeidade diante das outras crianças. Lá, Arendt seguia a orientação materna de se retirar da escola diante de um ato anti-semita. Em 1933, não. Ali Arendt soube, voltando a Kant (1985, p. 100), "servirse de si mesm[a] sem a direção de outrem. [Teve] a coragem de fazer uso de [seu] próprio entendimento".

\footnotetext{
${ }^{25}$ Kurt Blumenfeld foi, desde 1908, secretário executivo e o principal porta voz da Organização Sionista da Alemanha.

${ }^{26}$ Numa carta a Jaspers de 7 de setembro de 1952, Arendt (2010b, p. 186) diz que "Debido a mi entorno familiar, yo era simplemente una ingenua; la llamada cuestión judía me aburría. A este respecto me abrió los ojos Kurt Blumenfeld, que se convertió entonces en un buen amigo, y que sigue siéndolo".
} 
Quando diz que procurou "agir por vários campos" Arendt sublinha a ação política que, segundo sua interpretação, enraíza-se na natalidade, já que o nascimento humano, mais do que a aparição de um novo ser vivente, significa uma singularidade capaz de começar algo por si em meio a uma trama de relações humanas. Arendt entendia que, ao agir, nascemos outra vez. Assim, 27 de fevereiro de 1933 marca seu segundo nascimento: foi quando percebeu a necessidade de agir no âmbito político, de revelar-se ante os outros. Provém daí o sentido de ela dizer a Gaus que

Pertencer ao judaísmo [...] tornou-se manifestamente meu próprio problema, e [...] era político. Exclusivamente político. Eu queria engajar-me praticamente em um trabalho e queria que fosse um trabalho judaico, e foi assim que me dirigi para a França (ARENDT, 1993a, p. 133).

Note-se que essa tomada de consciência ocorre justamente com a chegada dos nazistas ao poder, isto é, a partir do instante em que o espaço público vai gradativa e exponencialmente se fechando aos judeus. A partir daí, entra em ação o ator: "Não era mais possível contentar-se em ser espectador". Isso não significa que Arendt abandona sua condição de espectadora do mundo: é que já não se contenta apenas com essa condição. Após o choque do Reichstag, procura "agir por vários campos" e nesse percurso assume a atitude do proscrito, do pária consciente, empenhando-se num resgate do que nomeará mais tarde de tradição oculta do judaísmo.

Produzida no calor dos tempos sombrios - expressão tomada do poema de Brecht Aos que virão a nascer - e, depois, no contexto da Guerra Fria, a obra de Arendt é de uma originalidade e uma independência incomuns no contexto marcadamente ideologizado do pósguerra. Tal independência aparece num ensaio de Arendt (1991, p. 17, grifo nosso) sobre Lessing:

Nenhum dever me obriga a resolver as dificuldades que crio. Possam as minhas idéias ser sempre um tanto desconexas, ou mesmo contradizer-se aparentemente umas às outras desde que sejam idéias onde os leitores encontrem material que os leve a pensar por si próprios.

A passagem é do próprio Lessing, mas pode perfeitamente se aplicar a Arendt. Há tensões em aberto em sua obra que ela nunca pretendeu resolver. Como Lessing - e, por que não dizer, Sócrates -, ela formula um problema da mais alta importância política, mas sem a pretensão de resolvê-lo. Essas aporias que revelam sua paixão por compreender são um convite a pensar com ela, em alguns casos contra ela e, no mais das vezes, a partir de seus 
insights. Arendt encarou o desafio de pensar por si mesma ${ }^{27}$ sobre os tempos sombrios que viveu e nunca pretendeu vincular seus exercícios de pensamento a nenhum resultado prático, tampouco que servissem de guia à ação política. E ainda que essa independência não explique em si mesma algumas das polêmicas às quais ela se viu arrastada - a Jaspers ela confia que "a mí me gustan las peleas" (ARENDT, 2010b, p. 132) -, entre os historiadores, infelizmente, sua obra ainda está longe do reconhecimento que alcançou em outros âmbitos das ciências humanas. ${ }^{28}$ Essa falta de reconhecimento tem múltiplas razões e diz respeito à recepção da obra de Hannah Arendt no Brasil. ${ }^{29}$

Seja como for, causa certa perplexidade o fato de que um autor difícil como Walter Benjamin, contemporâneo e amigo de Arendt nos anos de exílio francês, figure entre nós como destacado interlocutor do debate historiográfico, especialmente suas Teses sobre o conceito de história, manuscrito que confiou a Arendt antes de seu trágico suicídio em 1940. Ora, a obra de Arendt não tem o hermetismo e a linguagem excessivamente metafórica ${ }^{30}$ e prenhe de aforismos de Benjamin, e em que pese a diferença que há entre os interesses intelectuais dos dois - é bom convir que não são poucos -, as reflexões que ambos dedicaram ao âmbito da história estão cheias de afinidades.

Formada ao longo dos anos 1920, aluna de Husserl, Heidegger e Jaspers, de quem obteve um profundo contato com a fenomenologia e a filosofia da existenz, Hannah Arendt se doutorou aos 23 anos em 1929, com uma tese sobre O conceito de amor em Santo Agostinho, ${ }^{31}$ pensador que permeia seus trabalhos posteriores. Mas a primeira obra que publicou depois do esclarecimento de 1933 e do período em que se dedicou a "agir por vários campos" foi Sechs Essays, em 1948. ${ }^{32}$ Na dedicatória a Jaspers, Arendt (2008b, p. 241, grifo nosso) destaca o significado político da judeidade:

\footnotetext{
${ }^{27}$ Ainda sobre Lessing, Arendt (1991, p. 19) diz: “A relação secreta entre o seu 'pensamento próprio' [selbstdenken] e a ação residia no facto de ele nunca vincular o seu pensamento a resultados. Com efeito, renunciou explicitamente ao desejo de obter resultados, na medida em que estes pudessem representar a solução final dos problemas que o pensamento colocava a si próprio; o seu pensamento não foi uma demanda da verdade, pois cada verdade que é o resultado de um processo de pensamento põe necessariamente fim ao movimento do pensamento".

${ }^{28}$ A esse respeito, ver CAVALCANTE, 2001.

${ }^{29}$ Sobre a recepção da obra de Hannah Arendt entre nós, há o ensaio de Celso Lafer (2001) Reflexões de um antigo aluno de Hannah Arendt sobre o conteúdo, a recepção e o legado de sua obra, no $25^{\circ}$ aniversário de sua morte.

${ }^{30}$ A esse respeito, Arendt (1991, p. 192-3) diz: "O que é tão difícil de entender em Benjamin é que, sem ser poeta, ele pensava poeticamente, e por conseguinte não podia deixar de considerar a metáfora como o maior dom da linguagem".

${ }^{31}$ ARENDT, 1997.

${ }^{32}$ Com exceção da Dedicatória a Karl Jaspers (ARENDT, 2008b, p. 240-244), seguimos a tradução espanhola já citada.
} 
Nenhum dos ensaios aqui presentes foi escrito, espero, sem consciência dos fatos de nossa época. E sem a consciência do destino judaico em nosso século. Mas acredito e tenho esperança de não ter adotado em momento algum uma posição baseada apenas nesses mesmos fatos, de não ter aceitado o mundo criado por tais fatos como um fenômeno necessário e inexorável. Sem sua filosofia e sem sua existência [...] eu nunca conseguiria ter adotado uma deliberada independência de julgamento, uma distância consciente de todos os fanatismos.

A tragédia política vivida pelos judeus e a resposta de Arendt em Sechs Essays, assim como os ensaios póstumos de The Jew as Pariah, são importantes pistas sobre como ela construiu uma particular abordagem histórica de alguns acontecimentos relevantes do século $\mathrm{XX} .{ }^{33}$ Em primeiro lugar, a facticidade, isto é, o domínio dos fatos históricos implica que o narrador deva tomá-los como ponto de partida, embora isso não signifique aceitar "o mundo criado por tais fatos como um fenômeno necessário e inexorável”, como revela a Jaspers. Em outras palavras, o destino dos judeus, para ser fiel à terminologia por ela empregada, não estava determinado previamente. Tampouco era o desfecho necessário de um processo natural ou histórico. Em segundo lugar, a dedicatória a Jaspers assinala um vínculo que transcende a amizade e a memória do antigo mestre, pois se inscreve na gratidão intelectual com que se sentiu capaz de julgar com independência e distância ${ }^{34}$ a tragédia que se abateu sobre o povo judaico.

O que salta aos olhos quanto ao julgar com independência e distância é que se tanto o ator político quanto o espectador podem ajuizar, de fato, não é possível agir e contemplar ao mesmo tempo um fenômeno. Isso não significa que ator e espectador não possam estar contidos na mesma pessoa, em distintos momentos. ${ }^{35}$ Esse é precisamente o caso de Tucídides, que primeiro foi ator - comandante das tropas atenienses na Trácia - e depois, na distância proporcionada pelo exílio, compôs sua narrativa. Tucídides representa para Arendt um paradigma do juízo histórico imparcial. No fundo, a experiência totalitária é um convite a repensar o significado mais profundo da imparcialidade e da objetividade histórica legadas pela tradição, tema a ser tratado no próximo capítulo.

\footnotetext{
${ }^{33}$ Numa entrevista concedida a Manuel Cruz, Benhabib (2007, p. 60, grifo nosso) observa: "Sus maravillosos ensayos sobre la cuestión judía, que fueron publicados póstumamente [...] serán reeditados. De modo que, al menos por lo que respecta al estudio de Arendt, estamos en mitad de una continua lectura y relectura".

${ }^{34}$ Kant é uma referência fundamental nas reflexões de Arendt sobre a faculdade do juízo. Numa carta a Jaspers de 29 de agosto de 1957, ela reconhece que sempre amou a obra de Kant dedicada ao juízo, mas que a crítica kantiana nunca a havia entusiasmado tanto como agora, depois de ler um ensaio de Jaspers sobre Kant (Cf. ARENDT, 2010b, p. 139).

${ }^{35}$ Essa observação adveio com a leitura da tese de doutorado de Adriano Correia (2002a), especialmente do capítulo $O$ espectador o ator.
} 
A tradição rompe-se definitivamente com a emergência dos campos de concentração, e Arendt toma para si a tarefa de pensar e compreender o terror totalitário. Em algum momento, ela deixa as vestes do espectador e assume as do ator ou faz o contrário. Se ela própria, ao fim da vida, dizia não ter vocação para a ação política, sua condição de pária consciente não pode ser debitada somente do teor de suas reflexões políticas, mas diz respeito à tragédia pessoal que, como judia, tocou-lhe viver e à responsabilidade que assumiu perante o mundo ao decidir agir politicamente.

O ano de 1951 marca não apenas a publicação de Origens do totalitarismo, mas a obtenção da cidadania americana. Arendt deixa de ser apátrida, resgata o direito de pertencer a uma comunidade política. Desde 1941, ano da chegada aos Estados Unidos, ela publica uma série de ensaios em periódicos americanos e alemães e torna-se frequente colaboradora do jornal Aufbau, periódico judaico-americano em língua alemã. Ali defenderá suas opiniões, entre elas a de que os judeus deveriam constituir um exército nacional para lutar junto aos Aliados contra os regimes totalitários e de que a empreitada judaica na Palestina deveria realizar-se com a fundação de uma federação árabe-judaica sob os auspícios da ONU. Enfim, os anos de redação de Origens do totalitarismo (1945-1949) se amalgamam a uma intensa ação de persuadir - por meio da imprensa e de periódicos acadêmicos - os demais interlocutores do debate em torno da tragédia judaica e da futura criação de um Estado judaico na Palestina, visando à busca de um acordo possível. Em consonância com os gregos, o desejo de Arendt de persuadir está intimamente relacionado à reivindicação de uma opinião (doxa) que, diferentemente do poder coercitivo da verdade, necessita de um intenso diálogo para se fazer entender. ${ }^{36}$

\subsection{O exílio e a descoberta de uma tradição oculta}

Em janeiro de 1943, o Menorah Journal publica o profundo e irônico ensaio de Arendt We refugees. Ao empregar a primeira pessoa do plural, o ensaio assume caráter de manifesto: “En primer lugar, no nos gusta que nos llamen 'refugiados'. Nosotros mismos nos llamamos unos a otros 'recién llegados' o inmigrantes" (ARENDT, 2005b, p. 1). Além do fato de que todo recém-chegado é um estrangeiro, um imigrante, não se trata de mera questão semântica. De fato, faz-nos lembrar a pergunta comum que se faz ao recém-chegado: Quem é você?

\footnotetext{
${ }^{36}$ Cf. COLLIN, 2006, p. 235.
} 
Na tradição literária ocidental, a resposta está na Odisséia e foi dada por Ulisses na corte de Alcinoo, rei dos feácios: Um mortal. Aqui, o que a ironia de Arendt deixa transparecer é que talvez a resposta mais adequada diante da condição do judeu refugiado seria: Sou um judeu. Os judeus recém-chegados aos Estados Unidos poderiam responder também: sou um ser natal e, como tal, tenho o poder de começar algo novo, de confirmar aquele traço recebido e não escolhido - minha judeidade - e iniciar alguma coisa por minha conta na companhia de outros seres natais como você. Mas a opinião de Arendt (2005b, p. 13, grifo nosso), oculta pela ironia, é diversa: "La desesperada confusión de estos Ulises vagabundos que, a diferencia de su gran prototipo, no saben quiénes son se explica fácilmente por su rematada manía de negarse a preservar su identidad".

Um refugiado? Não. Uma recém-chegada que, expulsa de sua comunidade política, elegeu os Estados Unidos como uma possível pátria de amizade. Convém lembrar que muito antes de Arendt recuperar seus direitos políticos em 1951, agora como cidadã americana, a chegada aos Estados Unidos lhe devolveria o imprescindível direito à palavra, à opinião, à publicidade de seus pensamentos, à possibilidade de tomar parte do debate político, ${ }^{37}$ submetendo ao público suas posições - o que fez na condição de refugiada. Ora, ao contrário do que comumente define um refugiado, "una persona obligada a buscar refugio por algún acto cometido o por sustener alguna opinión política" (ARENDT, 2005b, p. 1), os refugiados a que Arendt se refere não cometeram transgressão alguma nem crime algum. Irônica, ela explica

[...] que habíamos dejado nuestro país porque un buen día ya no nos convenía quedar-nos, o por razones puramente económicas. Queríamos rehacer nuestras vidas, eso era todo. Para rehacer la propia vida hace falta ser fuerte y optimista. De modo que somos muy optimistas (p. 1-2).

Otimismo admirável, uma vez que:

Perdimos nuestro hogar, es decir, la cotidianeidad de la vida familiar. Perdimos nuestra ocupación, es decir, la confianza de ser útiles en este mundo. Perdimos nuestra lengua, es decir, la naturalidad de las reacciones, la simplicidad de los gestos, la sencilla expresión de los sentimientos. Dejamos a nuestros parientes en los guetos polacos y nuestros mejores amigos han

\footnotetext{
${ }^{37}$ Nos anos 1970, quando dava conferências sobre a filosofia política de Kant na New School, Arendt (1993b, p. 43) recordava à platéia as palavras do autor em Crítica da razão pura: "Nossa época é, em grau especial, a época da crítica, e a essa crítica tudo deve ser submetido". Recordava também que publicidade "é um dos conceitos chaves do pensamento político kantiano"; que "a comunicabilidade - a necessidade de os homens comunicaremse - e a publicidade, e liberdade pública não apenas para pensar, mas também para publicar - "a liberdade de escrita" (p. 27-28) -, eram fundamentais.
} 
sido asesinados en campos de concentración, lo que equivale a la ruptura de nuestras vidas privadas (p. 2).

Perdas. E demasiadas. De todas, porém, uma se revela em toda a amplitude política: a perda de um lugar próprio no mundo, onde seja possível sentir-se em casa tal como se é. Ou seja, como judia. ${ }^{38}$ Supõe-se a hospitalidade por parte daqueles que acolhem um recémchegado. De volta à Odisséia, Ulisses chega nu à ilha dos feácios e ganha vestes principescas. Também chega faminto e o rei lhe oferece um banquete, jogos e cantos. Por fim, grandes navegadores que são, os feácios lhe emprestam uma embarcação e o conduzem a um ponto onde pode reencontrar o caminho de casa.

Seja como for, o alvo do texto We refugees é a comunidade judaica. Ela torna oportuno um exame crítico do significado antipolítico da assimilação, tema de que já se ocupara quando, no início dos anos 1930, antes de partir para o exílio francês, redigiu a biografia de Rahel Varnhagen, ${ }^{39}$ na qual pretendia demonstrar as armadilhas da tese assimilacionista. Aqui, retomando Rahel Varnhagen, diz:

A falta de valor para luchar por un cambio de nuestra condición social, política y jurídica, muchos de nosotros hemos decidido intentar, en lugar de eso, un cambio de identidad. Y este curioso comportamiento hace las cosas mucho más difíciles. La confusión en la que vivimos es en parte nuestra propia obra. [...] Hagamos lo que hagamos, finjamos lo que finjamos ser, no hacemos más que revelar nuestro insensato deseo de transformación, de no ser judíos. Todas nuestras actividades están dirigidas a conseguir este objetivo: no queremos ser refugiados, puesto que no queremos ser judíos (ARENDT, 2005b, p. 10-11, grifo nosso).

Arendt não nega que haja um propósito na tentativa de transformar a identidade, no desejo de não ser tomado socialmente como judeu. Tampouco que o caminho para tal transformação passe pelo reconhecimento social: "Estamos - y siempre lo estuvimos preparados para pagar cualquier precio con el fin de ser aceptados por la sociedad" (p. 14). De fato, a vida se torna extremamente difícil quando a trama das relações humanas é diluída. Nessa situação, não é nada fácil conservar a própria integridade quando as condições sociais,

\footnotetext{
${ }^{38}$ Numa carta a Jaspers de 29 de janeiro de 1946, Arendt (2010b, p. 121) justifica, a despeito de estar casada com Heinrich Blücher, a manutenção do nome de solteira: "En cuanto a mi nombre, podemos seguir con el antiguo. En América esto es completamente normal cuando la mujer también trabaja, y por conservadurismo he asimilado gustosamente esta costumbre (y también porque quería que se me siguiese reconociendo como judía por mi nombre)".

39 A biografia de Rahel Varnhagen, pela fecundidade com que ilumina o recurso de Arendt ao método biográfico, oferece pistas importantes sobre a forma como lida com a narrativa. Rapchan (2004, p. 304) observa que "o recurso ao método biográfico adotado por Arendt permite a aproximação de dois momentos históricos: o seu próprio e o de Rahel. Rahel viveu tempos em que a possibilidade de direito dos sujeitos, apesar de pálida, assustadiça e cambaleante, foi posta. Arendt viveu num contexto de crises tão agudas, que puseram essa possibilidade em cheque, apesar da longa e tortuosa jornada que tinha sido trilhada, até ali, em seu favor".
} 
políticas e jurídicas se tornaram tão difusas. Os problemas relacionados à emergência de uma esfera social que dilui as fronteiras entre o público e o privado ao longo da modernidade aparecem com toda a força em A condição humana, de 1958. Mas aqui Arendt (2005b, p. 9, grifo nosso) já os prenuncia ao dizer que:

[...] en este mundo insensato es mucho más fácil ser aceptado como un "gran hombre, ${ }^{, 40}$ que como un ser humano. Cuanto menos libres somos para decidir quiénes somos o para vivir como nos gusta, más intentamos construir una fachada, esconder los hechos y representar papeles. Fuimos expulsados de Alemania porque éramos judíos. Pero apenas cruzamos la frontera francesa, nos convirtieron en "boches" [isto é, alemães] [...]. Fuimos los primeros "prisonniers volontaires" conocidos en la historia. Después que los alemanes invadieron el país, el gobierno francés no tenía más que cambiar el nombre de la empresa: encarcelados por ser alemanes, no se nos liberó porque éramos judíos.

Arendt dá, assim, um testemunho do que significa a armadilha social da assimilação, do acosmismo e do apoliticismo ${ }^{41}$ judaicos. Courtine-Dénamy (1999, p. 23) sublinha: “A dupla crença na eleição e na esperança messiânica teria tido por efeito não ligar os judeus ao destino da humanidade". Um povo disperso entre nações ou, caso se prefira, uma nação entre nações-Estado viveu - aqui considerado o anti-semitismo moderno - o dilema de cada um escolher entre ser pária ${ }^{42}$ ou parvenu. O primeiro, por bendizer o judaísmo, pagava o preço de ser um proscrito social, vivendo à margem da boa sociedade. O segundo, ao assimilar-se, admitia renunciar ao judaísmo como preço de se tornar um parvenu, integrar-se à sociedade, obter algum status social. Contudo, quando os judeus se mostravam leais a determinada nacionalidade, eram vistos com suspeição. Assimilavam-se, na interpretação de Arendt (2005b, p. 13), conseguindo uma façanha sem precedentes: "aun probando todo el tiempo su carácter no judío, consiguieron continuar siendo judíos a pesar de todo”.

\footnotetext{
${ }^{40}$ Essa questão aparece na resenha que Arendt (2004a, p. 88) fez para The world of yesterday, de Stefan Zweig, em 1943: "Los judíos en el mundo de ayer". "Sin la coraza protectora de la fama, desnudo y desposeído, Stefan Zweig topó con la realidad del pueblo judío. Había habido muchas formas de evitar convertirse en un paria, entre ellas la torre de marfil que era la fama".

${ }^{41} \mathrm{Na}$ entrevista concedida a Gaus em 1964, ele formula a seguinte pergunta a Arendt: “[...] o povo judeu é um povo apolítico?". Ao que Arendt (1993a, p. 138) responde, relativizando: "Não chegaria a dizer isso, pois as comunidades eram igualmente políticas até certo ponto. A religião judia é uma religião nacional. Mas o conceito do político, entretanto, só funcionava com grandes restrições. Essa perda de mundo que o povo judeu sofreu durante a diáspora, e que, como em todos os povos párias, criou uma particular relação calorosa entre os seus membros, tudo isso foi modificado com a criação do Estado de Israel".

${ }^{42}$ A condição do pária já figura na biografia que Arendt (1994, p. 176) escreveu sobre Rahel Varnhagen: "Por isso os párias sempre representam, numa sociedade baseada em privilégios, orgulho do nascimento e arrogância do título, a verdadeira humanidade, o especificamente humano, o destacado da generalidade. A dignidade humana, o respeito à pessoa que o pária descobre instintivamente, é o único estágio preliminar natural para o conjunto da estrutura moral universal da razão".
} 
Arendt conta a trágica história de certo judeu, o sr. Cohn de Berlim, um legítimo patriota alemão que em 1933 encontrou refúgio em Praga, convertendo-se num autêntico patriota tcheco. Em 1937, já sofrendo certa pressão dos nazistas, o governo tcheco começa a expulsar os judeus de seu território e o sr. Cohn se vê na urgência de partir para Viena. Ora, para viver em Viena era necessário abraçar o patriotismo austríaco, tarefa simples para o sr. Cohn. Com a invasão da Áustria pelos nazistas, ele parte para Paris convencido de que seu futuro estaria na França e, logo, trata de se adaptar, ainda que o governo francês jamais lhe tenha dado uma permissão regular de residência. Arendt interrompe a narrativa da história do sr. Cohn chamando a atenção para o que significa para um judeu tentar perder essa identidade numa sociedade anti-semita: significa aceitar o anti-semitismo. Antes mesmo de se ver obrigada a partir para o exílio, Arendt já sustentava tal posição. Na biografia de Rahel Varnhagen, ela sublinhara:

Nenhuma assimilação podia ser alcançada renunciando-se simplesmente ao próprio passado, mas ignorando o passado estrangeiro. Numa sociedade totalmente hostil aos judeus - e essa situação ocorreu em todos os países em que os judeus viveram, até o século XX - só é possível assimilar-se assimilando-se ao anti-semitismo (ARENDT, 1994, p. 185).

É inegável que ela reivindica sua judeidade no exato sentido de uma nacionalidade política - o que naquele contexto não era pouco -, e não o faz por razões religiosas ou culturais. Mas não toma nenhuma atitude temerária a esse respeito. Muito pelo contrário. Diante da embaraçosa pergunta quem é você??, ao reconhecer o perigo por trás da resposta política eи sои ит јиdeu que porventura pudessem dar esses "Ulisses vagabundos que não sabem quem são", tal como o sr. Cohn, ela diz:

Pero antes de lanzarnos la primera piedra, recuerda que ser judío no da ningún reconocimiento jurídico en este mundo. Si empezáramos contando la verdad de que no somos sino judíos, ello supondría exponernos al destino de los seres humanos que, sin la protección de ninguna ley o convención política concreta, no son nada más que seres humanos. Apenas puedo imaginarme una actitud más peligrosa, puesto que vivimos de hecho en un mundo en el que los seres humanos como tales han dejado de existir por un buen rato (ARENDT, 2005b, p. 13-14).

Ora, importa saber qual desdobramento analítico Arendt vai empreender, em We refugees, ao constatar essa fragilidade jurídica que tornou os judeus descartáveis e supérfluos aos olhos dos regimes totalitários. Para tanto, digamos que ela não apenas dá uma resposta política ao problema, mas vai um pouco além. Hobsbawm (1984, p. 22) pondera que todos os historiadores acabam por se envolver no processo de invenção de tradições, "uma vez que 
eles contribuem, conscientemente ou não, para a criação, demolição e reestruturação de imagens do passado que pertencem não só ao mundo da investigação especializada, mas também à esfera pública onde o homem atua como ser político". Sob este aspecto, Arendt parece estar bem consciente de que inventa uma tradição. Uma tradição não reconhecida, uma tradição oculta, como ela dirá:

La historia moderna de los judíos, que empezó con los judíos cortesanos y siguió con los judíos millonarios y filántropos, puede muy bien hacer olvidar esa otra corriente de la tradición judía: la tradición de Heine, Rahel Varnhagen, Sholom Aleichem, de Bernard Lazare, Franz Kafka o incluso Charlie Chaplin. Es la tradición de una minoría de judíos que no han querido convertirse en advenedizos, [parvenus] que prefirieron el estatuto de "parias conscientes" (ARENDT, 2005b, p. 14).

Não seria um exagero incluí-la nessa tradição oculta dos párias conscientes. Ao nós, os refugiados, Arendt (2005b, p. 15) reclama o nós, os párias conscientes e rebeldes, aspirando a chegar, por fim, simplesmente ao nós, os judeus, como parte da pluralidade humana:

Aquellos pocos refugiados que insisten en contar la verdad, aun a riesgo de
caer en la "inconveniencia", obtienen a cambio de su impopularidad una
inapreciable ventaja: la historia deja de ser para ellos un libro cerrado y la
política no es ya el privilegio de los gentiles. [...] Los refugiados empujados
de país en país representan la vanguardia de sus pueblos si conservan su
identidad. Por vez primera la historia judía no va por separado, sino ligada a
la de todas las demás naciones. El entendimiento entre los pueblos europeos
se hizo añicos cuando y porque permitió que su miembro más débil fuera
excluido y perseguido.

É preciso insistir que seria um equívoco ver na assunção da judeidade qualquer espécie de essencialismo judaico. O que Arendt pretende não é conferir aos judeus um lugar privilegiado, mais alto ou capaz de desvelar melhor a realidade; antes, que a ação política e a história também estão abertas a eles. Ao dizer que pela primeira vez a história dos judeus não caminha separada das demais nações, o que Arendt faz é politizar a judeidade. Reivindica a identidade judaica como parte da pluralidade humana, que esteve ameaçada. Nesse ponto, Courtine-Dénamy (1999, p. 26) observa com razão que é justamente "porque sua identidade judaica e todo o judaísmo são atacados, que Arendt recusa sua pertença à 'essência alemã', escolhendo evidenciar o que poderia ter permanecido apenas uma particularidade, uma 
diferença entre outras". O que ela ressalta é o vínculo entre natalidade e judeidade, como transparece numa carta ao amigo Gerson Scholem: ${ }^{43}$

Siempre he considerado mi condición judia como uno de los datos incontrovertibles de mi vida, y acerca de tales facticidades nunca he deseado cambiar nada ni rechazar nada. Existe una cosa tal como una gratitud fundamental por todo aquello que es como es; por lo que nos es dado y que no hemos hecho, ni puede ser hecho (ARENDT, 2005b, p. 144; carta de 24 de julo de 1963).

Ora, longe se está de tomar esse dado incontroverso de Arendt - sua condição de judia -, como algo capaz de determinar sua análise histórica ou definir a marca de seu pensamento. A própria concepção de ação como início, como a capacidade de colocar em movimento algo novo e que, portanto, seja capaz de interromper o automatismo das coisas, parece desautorizar que se conceba a judeidade ou outro traço cultural e/ou biológico de um novo ser - inclusive Arendt - como algo que determine seja lá o que for. A ação é uma performance que revela o agente. Está arraigada à natalidade justamente na medida em que faz aparecer aos outros um quem. Por estar radicada ontologicamente na natalidade, "engajar-se politicamente por meio da ação e do discurso significa nascer para o mundo. Chegamos como estrangeiros e somos constitutivamente estrangeiros no mundo enquanto não nos decidimos a agir" (CORREIA, 2010b, p. 814).

$\mathrm{O}$ fato é que ninguém elege a forma como vem ao mundo. E todos, para Arendt, vêm e vão como estrangeiros. Entretanto, "Bendizer o que se é por ser" ${ }^{44}$ significa aceitar os dados incontroversos do nascimento como uma espécie de presente que se coloca em jogo na esfera política quando atuamos. Em outros termos, e em relação a Arendt, é sua biografia que ilumina sua judeidade, e não o contrário. E isso é fundamental. Nesse sentido é que se pode dizer que a perspectiva com que Arendt analisa historicamente os tempos sombrios está relacionada - ainda que jamais por ela determinada - à sua judeidade. Sempre nascemos duas vezes: primeiro, quando somos trazidos ao mundo; depois, quando confirmamos e atualizamos no âmbito público essa aparição, revelando nossa singularidade por atos e palavras:

Se tão explicitamente sublinho a minha pertença ao grupo dos judeus expulsos da Alemanha [...] é para prevenir certos equívocos que muito

\footnotetext{
43 Por ocasião da publicação de Eichmann em Jerusalém: um relato sobre a banalidade do mal, de 1963, e da imensa controvérsia daí surgida, Scholem escreve uma dura carta a Arendt comentando e reprovando a publicação (Cf. ARENDT, 2005b, p. 137-150).

44 "Bendice lo que és por ser": fragmento de um poema de Wystan Auden que Arendt adorava citar (Cf. ARENDT, 2005b, p. XV, n. 15).
} 
facilmente se podem gerar quando falamos de condição humana. Neste contexto, não posso passar em claro o fato de durante muitos anos ter considerado que a única resposta correta à pergunta "Quem és?" era "Uma judia". Só essa resposta levava em conta a realidade da perseguição (ARENDT, 1991, p. 28).

A identidade judaica (ou a muçulmana ou a cristã) obviamente não pode responder pela singularidade de nenhum sujeito, pois a singularidade excede a identidade. Mas quando se nega não a um judeu singular, mas ao coletivo de judeus o direito de compartilhar um mundo comum, então já não é mais possível responder à ordem Avança, judeu! como fez o personagem Natã, o Sábio, de Lessing: "Eu sou um homem". Ser judeu, nesse caso, representava exatamente não ser um homem, pressuposto lógico da solução final.

Arendt (1991, p. 92) exibiu sua judeidade diante da luz pública e reivindicou que os judeus partilhassem dessa humanitas que atribui à vida de Jaspers, uma vida que ela resume na palavra claridade:

Tudo quanto enfrenta a luz e não se dissipa em fumo sob a sua claridade, partilha da humanitas; propormo-nos responder perante a humanidade por cada pensamento significa vivermos nessa luminosidade que nos põe à prova a nós e a tudo o que pensamos.

Convém insistir que a judeidade de Arendt como traço de pertencimento político ao mundo não é um simples fato do nascimento biológico (zoe), mas algo que está implicado no confronto dessa condição natal (bios) perante a história, a política, e, consoante a isso, na percepção de si mesma como perseguida política, em seu consequente exílio e na postura assumida do pária consciente. A fim de evitar mal-entendidos e rechaçar de vez qualquer essencialismo judaico por parte de Arendt, vale recordar suas palavras ao receber o prêmio Lessing em Hamburgo, no ano seguinte à homenagem a Jaspers:

Quando utilizo a palavra "judeu" não pretendo sugerir a existência de um tipo especial de ser humano, como se o destino judeu fosse representativo ou arquetípico do destino do gênero humano. [...] Ao dizer "judeu", não aludia sequer a uma realidade esmagada ou especialmente assinalada pela história. Referia-me simplesmente a um fato político em virtude do qual a minha qualidade de membro desse grupo se sobrepunha a todas as outras questões de identidade pessoal, ou antes as resolvia em proveito do anonimato, da ausência de um nome. Hoje em dia semelhante atitude pareceria uma pose (ARENDT, 1991, p. 28). 
1.4.1. Rahel Varnhagen: a dádiva da judeidade

Ainda que Sechs essays figure como primeira obra de Arendt publicada na Alemanha após seu exílio, o manuscrito sobre Rahel Varnhagen estava pronto, "exceto os dois últimos capítulos", dirá Arendt (1994, p. 9) no prefácio de 1958, “quando deixei a Alemanha, em $1933,{ }^{45}$ e mesmo estes foram escritos há mais de vinte anos". Os capítulos finais provavelmente foram redigidos sob pressão, no verão de 1938, como relata a Jaspers: "lo termine ya irritada, porque Heinrich [Blücher] y [Walter] Benjamin no me dejavan em paz" (ARENDT, 2010b, p. 185; carta de 7 de setembro de 1952). Convém ressaltar a opinião de Benjamim sobre o manuscrito:

Ese libro me ha causado una gran impresión. Con fuertes impulsos va nadando contra la corriente de los estudios del Judaísmo de carácter edificante y apologético. Sabe mejor que nadie que todo lo que se ha podido leer hasta la fecha sobre los judios en la literatura alemana se dejaba arrastrar precisamente por esa corriente. (Carta de Benjamin a Scholem em 20 de fevereiro de 1939; apud BIRULÉS, 2005a, p. XVI).

A Jaspers, que sempre teve restrições a essa obra, ${ }^{46}$ Arendt (2010b, p. 186) revela a perspectiva a partir da qual o livro foi concebido: "desde la crítica sionista a la asimilación, que había hecho mía y que aún hoy considero justificada en lo esencial" (carta de 7 de setembro de 1952). No prefácio, ela aponta o que considera um limite à contribuição histórica da biografia, lembrando que aborda "apenas um dos aspectos dos complexos problemas da assimilação: ou seja, a maneira pela qual a assimilação à vida intelectual e social do meio funciona concretamente na história de um indivíduo, moldando assim um destino pessoal" (ARENDT, 1994, p. 13). Ainda, ela ressalta a particularidade da relação entre os alemães e os judeus de idioma alemão como uma ocorrência cultural única e incomparável em todas as áreas de assimilação judaica que, "naturalmente, somente pode ser atacada agora, depois que a História dos judeus alemães chegou a um fim" (p. 12).

A crítica de Arendt à assimilação não se restringe a um problema sociológico quanto às formas, aos conflitos e aos limites da integração social dos judeus à época do Iluminismo. É verdade que o contexto da vida de Rahel, um fragmento da era moderna na passagem do

\footnotetext{
${ }^{45}$ A Jaspers, Arendt (2010b, p. 185) diz que talvez mesmo em 1932 (carta de 7 de setembro de 1952).

${ }^{46}$ Arendt sempre guardou certa relutância em publicar a obra sobre Rahel, relutância que Jaspers compartilhava por distintas razões, como demonstra numa carta a Arendt em 23 de agosto de 1952: "O que me impede de lhe aconselhar a publicação é o meu desejo de a ver soberana perante o público, no que diz respeito à questão judaica, de ver o que está impresso valer definitivamente, enfim, que seja menos injusta para com Rahel e as Luzes" (COURTINE-DÉNAMY, 1999, p. 169).
} 
século XVIII para o XIX, esteve marcado pela emergência de uma esfera social, isto é, pelo advento da sociedade moderna. Mas o tratamento que Arendt dá à questão é essencialmente histórico-político e não sociológico. Interessa-lhe perceber menos o caráter social da assimilação do que seus custos políticos. Isso porque a esfera social, um âmbito que de início se interpõe entre os domínios do público e do privado, com o tempo vai se espraiando e se sobrepondo aos outros dois, tornando não apenas cada vez mais indistinta a fronteira entre o público e o privado, mas corrompendo e fazendo declinar o sentido de ambos. ${ }^{47}$

Rahel Varnhagen teve uma presença marcante no cenário cultural alemão na virada do século XVIII para o XIX. Um tempo permeado pelos ideais do Iluminismo, pelo "efeito do culto a Goethe em Berlim, do qual ela [Rahel] foi verdadeiramente a iniciadora" (ARENDT, 1994, p. 11), pelo espírito do romantismo e por meio do salão literário que mantinha. Ao tempo do romantismo alemão, na perspectiva de uma judia como Rahel, assimilar-se significava ser aceito socialmente: "Os judeus, se desejassem desempenhar um papel na sociedade, tornavam-se, no século XIX, parvenus por excelência” (p. 166). E a despeito de a biografia escrita por Arendt revelar que Rahel tudo fez para lograr esse intento - isto é, assimilar-se -, quando sua heroína atinge por fim o objetivo de integrar-se à sociedade alemã, rebela-se. A ambiguidade presente nos conflitos de Rahel e em sua rebeldia é que parece estar por trás da sedução entre biografada e biógrafa: Rahel talvez seja uma espécie de paradigma do problema da assimilação, espécie de tipo ideal weberiano que oscila entre o pária $^{48}$ e o parvenu. Arendt (1994, p. 64) observa:

Não a haviam, todos, respeitado, admirado, cumulado com lisonjeira apreciação? Não havia alcançado mais do que qualquer outra pessoa, embora não fosse rica, nem bonita, não tivesse uma posição no mundo, sequer fosse casada? Não havia atraído para si, através de magia, pelo fascínio da personalidade, a todos que acaso fossem conhecidos na sociedade da época? [...] Cada um havia desfrutado do "espetáculo" que oferecia a todos; ninguém desejara aceitar a verdade que sempre estivera pronta a gritar à menor provocação.

Uma passagem da correspondência de Rahel resume bem a questão: "A verdade e eu ambas não visíveis, ambas sem brilho" (p. 65). Desponta aqui um aspecto que permeará toda

\footnotetext{
${ }^{47}$ Cf. ARENDT, 2010a.

${ }^{48}$ Convém lembrar que o próprio termo pária, em sua acepção política, foi cunhado por Weber, e Arendt toma de empréstimo a acepção distinta que lhe dá Lazare: o pária consciente. No instigante ensaio $O$ pária e $o$ cidadão, de Ferenc Fehér, ele lembra, contudo, que Arendt "só tomou emprestada uma intuição de Weber: $a$ ausência de comunidade política na longa história do pária judeu na Diáspora, com uma concomitante falta de autoconsciência política e, até quando já era tarde demais, um desinteresse geral pelos assuntos políticos do ambiente em que viviam os judeus" (HELLER; FEHÉR, 2002, p. 134, grifo nosso).
} 
a futura obra de Arendt: o quem alguém é só se revela aos outros e, para tanto, exige um espaço de aparição, uma visibilidade pública que Arendt mais tarde resgatará em seu diálogo com a tradição homérica e a historiografia antiga. As aspas no espetáculo significam que Rahel, em vez de agir por si própria, comportava-se, submetia-se a uma conduta esperada, longe de toda espontaneidade e naturalidade. Ao perceber que, na verdade, representava um papel, ela se rebela.

"Nascida judia e mulher, Rahel pensa-se como Schlemihl, ${ }^{49}$ azarenta, e vai, portanto, consagrar a maior parte de sua vida a tentar reparar o que lhe parecia 'a infâmia do seu nascimento', tentando assimilar-se à sociedade de sua época" (COURTINE-DÉNAMY, 1999, p. 170). O desejo de Rahel adquire um tom dramático pela forma com que Arendt (1994, p. 15) principia a obra, com as palavras da biografada em seu leito de morte: "A coisa que durante toda a minha vida pareceu-me a maior vergonha, a miséria e o infortúnio mais amargos - ter nascido judia -, desta eu não devo agora por nenhum motivo desejar ter sido privada".

Não desejar privar-se da dádiva de ter nascido judia e colocá-la em jogo, publicamente, no espaço entre-os-homens. Esse é o elo estritamente político que liga Arendt a Rahel. Young-Bruehl (1997, p. 92) assinala: “Tivesse sido Rahel uma mulher do século XX e não do século XVIII, a biografia de Arendt poderia ter sido a história de uma conversão ao sionismo", isto é, uma assunção política do judaísmo. Mas a diferença do contexto vivido por Rahel e Arendt é que a ascensão dos nazistas ao poder e sua concomitante política racista colocam um ponto final naquilo que marca a geração de Rahel Varnhagen: escapar ao judaísmo convertendo-se ao cristianismo e unindo-se em matrimônio com gentios. ${ }^{50}$

O problema estritamente político que Arendt enxerga no assimilacionismo em geral e no de Rahel Varnhagen, em particular - Varnhagen se ligara ao cristianismo, por casamento e conversão, aos 43 anos -, é que o preço de ser aceito socialmente é a renúncia à identidade judaica. A assimilação de Rahel soa a Arendt como a antítese da pluralidade, a recusa de

\footnotetext{
${ }^{49}$ Os tradutores da obra esclarecem o significado do termo Schlemihl numa nota: "Palavra iídiche, atualmente de uso corrente no alemão e no inglês americano, que significa 'tolo', 'azarado', 'mal-sucedido'. O schlemihl é um personagem típico da literatura e do folclore judaico-europeus, que bem poderia ser chamado, em português, de 'pobre-diabo', ou João-ninguém" (ARENDT, 1994, p. 15).

${ }^{50}$ Em relação à assimilação via casamento com não judeus, Benhabib (2000, p. 106, grifo nosso) observa: "Las estrategias de Rahel para enfrentar el destino de su judaísmo eran característicamente femeninas: asimilación y aceptación mediante relaciones amorosas, cortejos y, por último, matrimonio con hombres cristianos. [...] La estrategia femenina de asimilación por medio del matrimonio es posible, desde luego, en un mundo asimétrico de géneros, en el cual es el estatus público del esposo el que define a la mujer, y no al revés. La vida de Rahel Levin Varnhagen estuvo llena de historias de amores fracasados, promesas rotas y compromisos infructuosos. $A l$ darse a sí misma al hombre correcto, Rahel confiaba en conseguir el 'mundo' que le era negado como judía y como mujer".
} 
aparecer como se é. Como sublinharia mais tarde: "A pluralidade é a condição da ação humana porque somos todos iguais, isto é, humanos, de um modo tal que ninguém jamais é igual a qualquer outro que viveu, vive ou viverá" (ARENDT, 2010a, p. 9-10).

Se para Arendt a pluralidade "é especificamente $a$ condição de toda vida política" (p. 8-9) e ela percebe uma infinita pluralidade de seres singulares, o assimilacionismo é renúncia à política, porque implica a impossibilidade de autorrevelação do sujeito, o que apenas um espaço público compartilhado pode oferecer. "Rahel desejava escapar ao judaísmo" (ARENDT, 1994, p. 33). No sentido contrário, o sionismo a que Arendt adere, como se viu, pelas mãos de Kurt Blumenfeld - e do qual depois se afastará ${ }^{1}$ - toma como ponto de partida a própria judeidade que se afirma. Como diria ela em Origens do totalitarismo, o sionismo foi “a única resposta política que os judeus encontraram para o anti-semitismo, e a única ideologia na qual chegaram a levar a sério o comportamento hostil, o qual os impeliria para o centro dos acontecimentos mundiais" (ARENDT, 1989, p. 143).

Rahel não tinha um lugar no mundo, e "uma das questões básicas levantadas pelo início do romantismo [...] era justamente se alguém algum dia consegue encontrar um lugar no mundo" (ARENDT, 2008b, p. 82). Ela imaginou tê-lo durante o breve intervalo de tempo em que manteve seu salão literário no apartamento da Jägerstrasse, onde recebia membros da nobreza, ministros, diplomatas, artistas e escritores de seu tempo:

Conquanto fora possível aos judeus assimilar-se ao iluminismo, e apenas a ele, porque representava completamente a vida intelectual da Alemanha, uma elevação social para os judeus não era absolutamente necessária. [...] Assim, Moses Mendelssohn fora capaz de assimilar-se ao ambiente estranho sem abandonar seu judaísmo (ARENDT, 1994, p. 33).

Ao menos naquele mundo que Rahel criara em seu salão, a boa sociedade alemã dava as costas aos rigores sociais e às convenções:

O salão judeu, o idílio recorrentemente sonhado de uma sociedade mista [encontrava-se] [...] fora da sociedade burguesa. [Os judeus já estavam habituados] a desempenhar um papel, a representar alguma coisa, a expressar-se, a exibir "o que eles eram" em lugar de como os burgueses, "mostrar o que eles tinham", como Goethe exprimiu em Wilhenlm Meister (p. 56).

\footnotetext{
51 "Hablando en serio, tal como están las cosas yo, en cualquier caso, estoy fuera de la política judía. Soy de la opinión de que ya no se puede hacer nada con sentido dentro del mundo oficial de las organizaciones y del movimiento sionista, o al menos de momento" (ARENDT, 2010b, p. 122; carta a Jaspers de 11 de novembro de 1946). Em seguida, Arendt relata que a alternativa de momento é a oportunidade de trabalhar com política cultural na editora judaica Schocken Books, onde ela se empenhará pessoalmente na publicação de autores judeus como Kafka e Lazare, entre outros.
} 
Ainda que em seu tempo não pudesse, ao fim da vida, abraçar o sionismo, Rahel percebeu que mesmo o parvenu não deixa enfim de ser pária:

Como judia, Rahel sempre estivera do lado de fora, havia sido uma pária e descobrira por fim, muito a contragosto e infelizmente, que o ingresso na sociedade era possível apenas ao preço de mentir, de uma maneira muito mais generalizada do que simplesmente hipocrisia; descobriu que para o parvenu - mas apenas para ele - era necessário sacrificar todo o impulso natural, esconder toda a verdade, malbaratar todo o amor, não apenas para suprimir toda a paixão, mas, ainda pior, para convertê-la num meio de ascensão social (p. 172).

Essa oscilação entre a figura do parvenu e do pária e, por fim, a tardia consciência de Rahel sobre a dádiva de sua judeidade conferem à sua história um caráter dramático. O clímax da epopeia é quando o herói vive uma catarse, tal qual Ulisses, que, ao ouvir a história de seus feitos e infortúnios, chora e se reconcilia com a realidade. Uma reconciliação pela via da compreensão, pois, ao ouvir a própria história, vê nela um significado, deixa de ser um estrangeiro no mundo e reencontra seu lugar. Ora, quando Rahel bendiz o que outrora considerava um nascimento infame, compreende o significado de sua judeidade como dado incontroverso de seu nascimento, algo que não se pode eleger, mas simplesmente pôr em jogo no mundo, jogo toda a vida recusado por ela.

Arendt (1994, p. 11) deixa claro o caráter incomum da biografia de Rahel ao dizer no prefácio que pretendeu "narrar a história da vida de Rahel como ela própria poderia ter feito". 52 Aqui reside a originalidade de Arendt: sua fonte é a correspondência de Rahel, e o que esta revela, ao menos aos olhos da autora, é o sopro do pensamento que ganha materialidade na abundante correspondência. E se à verdade do nascimento infame corresponde a ausência de um lugar no mundo, é pela via do pensar - que não busca a verdade como cognição, mas o sentido - que a correspondência de Rahel dá testemunho de sua condição judia. Isso significa que muito antes de se ocupar teoricamente com as atividades mentais de A vida do espírito - um trabalho eminentemente teórico - Arendt já se dedicava a um caso concreto: diante da correspondência de Rahel, Arendt via um querer em atividade, um querer em conflito; um pensamento e uma imaginação em atividade buscando não a verdade, mas o sentido das coisas. Por fim, se para Arendt o juízo é a mais política de nossas

\footnotetext{
52 Arendt (1994, p. 11) observa: "Nunca foi minha intenção escrever um livro sobre Rahel, sobre sua personalidade, que se poderia prestar a várias interpretações de acordo com os padrões e categorias psicológicos adotados pelo autor; nem sobre sua posição no romantismo e o efeito do culto a Goethe em Berlim, do qual ela foi verdadeiramente a iniciadora; nem sobre suas idéias e sua concepção de mundo, na medida em que possam ser reconstituídas a partir de suas cartas. O que me interessava unicamente era narrar a história da vida de Rahel como ela própria poderia ter feito".
} 
atividades mentais, ela enxergava uma Rahel que, no leito de morte, reconciliava-se com sua judeidade.

Sem entrar no mérito ${ }^{53}$ quanto ao êxito de Arendt em "narrar a história da vida de Rahel como ela própria poderia ter feito", o que parece guiá-la por esse estranho caminho ${ }^{54}$ é uma estreita relação entre natalidade e política, bem como entre política e pluralidade, relação que marca toda a sua obra futura. Piña e Barrios (2012, p. 223) percebem bem a questão: "Rahel ve en su nacimiento la causa de su desgracia y no la posibilidad de un nuevo comienzo. [...] Pero, ¿quién es ella si olvida su vida? No habría iniciativa humana si se niega la propia identidad". E um pouco adiante: "No puede haber acción sin identidad. Rahel hace y dice cosas pero no actúa en el sentido arendtiano. Las actividades que lleva a cabo responden al “qué” y no al "quién”. Quiere ser alguien y piensa conseguirlo asimilándose” (p. 222).

Ora, se é a ação que revela o quem do agente - e, como tal, consiste em um fenômeno para aparecer à vista de todos -, Rahel não pode mesmo revelar quem ela é ao negar sua própria identidade.

\section{5. $\mathrm{O}$ direito à opinião $($ doxa $)$}

Para Arendt (2010a, p. 15), a política não nasce com o homem, nem pertence a uma suposta natureza humana, tampouco à zoe, mas relaciona-se à pluralidade dos homens que, ao agir, iniciam um bios politikos, "um modo de vida autônomo e autenticamente humano" por meio da ação e do discurso que a acompanha. A política surge, portanto, no espaço-entre os homens que se forma se e somente se eles decidem tomar em conjunto a tarefa de edificar um mundo comum por meio de ações, palavras, debates, acordos e promessas, mediante um espaço previamente construído (a polis, a república, ${ }^{55}$ o soviet, a comuna) para abarcá-la. Assim, quando Arendt diz que a política não é mais privilégio dos gentios e que a história do povo judeu já não é mais um livro fechado e caminha ligada às das demais nações, ela convida todos, mas especialmente a comunidade judaica, a sair do acosmismo, do

\footnotetext{
${ }^{53} \mathrm{Na}$ orelha do livro, pode-se ler o comentário de Eduardo Jardim de Moraes: "a maneira como esta biografia é contada e a reconstituição da época em que Rahel Varnhagen viveu, tendo como único recurso os seus pensamentos - na verdade, a matéria exclusiva com que Hannah Arendt lida -, dá ao livro um tom desconcertante e um lugar destacado na literatura do gênero".

54 "Rahel Varnhagen é uma biografia, mas certamente não de um tipo facilmente classificável. Não é tanto o que afirma seu subtítulo - 'A vida de uma judia' - quanto a vida de um pensamento pensado por uma judia" (YOUNG-BRUEHL, 1997, p. 92).

55 “Assim, a língua dos romanos - talvez o povo mais político que conhecemos - empregava como sinônimas as expressões 'viver' e 'estar entre os homens' (inter homines esse), ou 'morrer' e 'deixar de estar entre os homens' (inter homines esse desinere)" (ARENDT, 2010a, p. 9).
} 
apoliticismo, e inserir-se nesse espaço-entre onde pode nascer a política. Se suas teses não ecoaram entre sionistas ou não-sionistas, isso não diminui o fato de que Arendt interveio naqueles debates dos anos 1940 procurando persuadir os demais sobre o conteúdo de seus argumentos, buscando o acordo de muitos. Arendt reivindica mais o direito à opinião do que propriamente o conteúdo estrito de uma opinião.

Ao recuperar a tradição oculta encarnada na figura do pária consciente, num gesto rebelde e que não se submete à unanimidade da opinião pública ${ }^{56}$ - tão característica do mundo moderno -, Arendt (2010a, p. 71) resgata projetos vencidos: "O mundo comum acaba quando é visto somente sob um aspecto e só se lhe permite apresentar-se em uma única perspectiva". Em 5 de maio de 1948, por exemplo, poucos dias antes de Ben Gurion proclamar a criação do Estado de Israel, em 14 de maio, Arendt (2005b, p. 82) publica em Commentary o ensaio intitulado Salvar la patria judia: todavía se está a tiempo, a respeito das tensões entre árabes e judeus na Palestina:

Una opinión unánime es un fenómeno muy inquietante, característico de nuestra época moderna de cultura de masas. [...] pues la unanimidad de masas no es el resultado del acuerdo, sino una expresión de fanatismo e histeria. En contraste con el acuerdo, la unanimidad no se limita a ciertos objetos bien definidos, sino que se extiende como una infección por todos los asuntos que guardan entre si alguna relación.

Visou-se aqui sinalizar um traço do pensamento arendtiano: o modo como o mundo aparece à pluralidade dos homens é sempre distinto, e convém resguardar essa pluralidade de pontos de vista tanto quanto o direito à aparição pública: “A importância de ser visto e ouvido por outros provém do fato de que todos vêem e ouvem de ângulos diferentes. É esse o significado da vida pública." (ARENDT, 2010a, p. 70).

As fontes que sustentam essa visão se assentam sobre uma tríade, tal como em um acorde musical, e, como tal, sofrem modulações. Ora a tônica do pensamento de Arendt se enraíza na tradição oculta do judaísmo, ora na tradição homérica/polis pré-platônica, ora na interpretação que ela dá à filosofia política (não escrita) de Kant. Até aqui, ressaltou-se a assunção da judeidade na figura do pária consciente e rebelde, bem como sua estreita relação com a natalidade e a pluralidade. Todo o conjunto, toda a reflexão de Arendt está remetida a um acontecimento histórico que, em suas palavras, "jamais poderia ter ocorrido": Auschwitz.

\footnotetext{
${ }^{56}$ Segundo o Dicionário de política, a "Opinião Pública não coincide com a verdade, precisamente por ser opinião, por ser doxa e não episteme; mas, na medida em que se forma e fortalece no debate, expressa uma atitude racional, crítica e bem informada. A existência da Opinião Pública é um fenômeno da época moderna: pressupõe uma sociedade civil distinta do Estado, uma sociedade livre e articulada, onde existam centros que permitam a formação de opiniões.” (BOBBIO, 2009, p. 842).
} 
Os capítulos a seguir devem soar como modulações dessa tríade. A insistência nesse ponto vista pretendeu destacar a judeidade como matriz política do pensamento arendtiano, uma vez que, ao longo dos anos 1950, a questão judaica perde espaço para outras temáticas da autora, reaparecendo por ocasião de sua cobertura do julgamento de Eichmann, em 1961, e na publicação de Eichmann em Jerusalém, em 1963. ${ }^{57}$ Apesar de adquirir outro colorido nos trabalhos dos anos 1950, a revelação do quem da ação deriva primeiramente da constatação de uma ausência, da interdição da ação, isto é, da aparição de um alguém sob as condições totalitárias.

Em A condição humana e, posteriormente, em Entre o passado e o futuro, há uma modulação da tônica de seu pensamento. O que lhe servirá de guia para reconsiderar as atividades da vida ativa (o trabalho, a obra/fabricação e, fundamentalmente, a ação) será um reposicionamento teórico das experiências da vida ativa no mundo homérico e na polis préplatônica, e não mais na tradição oculta do judaísmo. Mas de onde brota o impulso que leva Arendt de volta ao círculo dos guerreiros homéricos e, depois, à polis grega e à república romana? Não creio que possa estar nas façanhas e nos sofrimentos de Aquiles, Ulisses, Heitor ou qualquer outro homem de ação imortalizado pela epopeia homérica. Tampouco nos discursos de Péricles ou de outro grande orador da Atenas clássica. O impulso está em Auschwitz.

Aos olhos de Arendt - e talvez em sua escuta -, Auschwitz representa o ocaso da tradição por significar o ocaso da ação (práxis) e da palavra (lexis) que a acompanha. $\mathrm{O}$ silêncio de Auschwitz é a impossibilidade da revelação de um quem. A experiência totalitária não significou apenas a interdição da resposta sou um judeu à pergunta quem é você??, em face da descartabilidade das vítimas, mas implicou também subverter todo e qualquer significado da morte como desfecho de uma vida de ação, de um bios politikos. Ainda que Arendt não soubesse quem ela era, até aqui foi possível saber que ela é uma mulher, apátrida, recémchegada e judia. Ela sabe ler o grego e o latim e vai travar um diálogo com os mortos, não para que estes não enterrem a si mesmos, como diria Marx, mas porque

Estamos ameaçados de esquecimento, e um tal olvido - pondo inteiramente de parte os conteúdos que se poderiam perder - significaria que, humanamente falando, nos teríamos privado de uma dimensão, a dimensão de profundidade na existência humana. Pois memória e profundidade são o

\footnotetext{
${ }^{57}$ Neste caso, entretanto, ainda que a pluralidade esteja presente na temática do livro - presença em negativo, pois se trata da eliminação da pluralidade articulada com as deportações em massa engendradas por Eichmann pode-se supor que a primazia aqui seja a possível relação entre a ausência de pensamento e a moralidade, o que permite indagar se o pensamento poderia evitar o mal.
} 
mesmo ou antes, a profundidade não pode ser alcançada pelo homem a não ser através da recordação (ARENDT, 1992, p. 131). 


\section{História, compreensão e reconciliação com o mundo}

Estamos ameaçados de esquecimento, e um tal olvido - pondo inteiramente de parte os conteúdos que se poderiam perder significaria que, humanamente falando, nos teríamos privado de uma dimensão, a dimensão de profundidade na existência humana. Pois memória e profundidade são o mesmo, ou antes, a profundidade não

pode ser alcançada pelo homem a não ser através da recordação.

(ARENDT, 1992, p. 131)

Nenhuma filosofia, nenhuma análise, nenhum aforismo, por muito profundos que sejam, podem comparar-se, na intensidade e na riqueza de sentidos, a uma história bem contada.

(ARENDT, 1991, p. 33)

\subsection{Afrontando o cânone historiográfico}

O ano de 1951 é emblemático na vida de Hannah Arendt por duas razões. A primeira é que, ao menos juridicamente, ela deixa a condição de refugiada e apátrida ao se tornar uma cidadã americana, embora suas análises conservem o espírito do pária consciente. A segunda é a publicação de Origens do totalitarismo, obra polêmica e inventiva que a tornaria conhecida mundialmente. Trata-se de uma extensa obra dividida em três partes - Antisemitismo, Imperialismo e Totalitarismo -, as quais ultrapassam 500 páginas. O prefácio à primeira edição resume-se a onze parágrafos - curtos, ainda que densos -, que não chegam a ocupar duas páginas e meia. Muito pouco para uma obra de tais dimensões, quanto mais para quem estava conscientemente afrontando o legado da teoria política, bem como o cânone historiográfico. Ao final do prefácio, Arendt (1989, p. 13) adverte:

Já não podemos nos dar ao luxo de extrair aquilo que foi bom no passado e simplesmente chamá-lo de nossa herança, deixar de lado o mau e simplesmente considerá-lo um peso morto, que o tempo, por si mesmo, relegará ao esquecimento. A corrente subterrânea da história ocidental veio à luz e usurpou a dignidade de nossa tradição.

A essa tradição usurpada ou, como dirá dez anos mais tarde no prefácio de Entre $o$ passado e o futuro, a essa herança sem testamento, Arendt contrapõe uma perspectiva analítica que revê o legado historiográfico, pondo em questão certas categorias fundamentais do procedimento histórico: contingência/causalidade; circularidade/linearidade; objetividadeimparcialidade/neutralidade; grandeza/processo-progresso; mortalidade/imortalidade, entre outras. É fato que Arendt nutre profunda ojeriza pelas questões metodológicas, pois as 
considera autoindulgentes e irrelevantes. Foi duramente criticada a esse respeito e pagou um alto preço ao negligenciá-las, até mesmo a pecha de subjetivismo. ${ }^{58}$ Não fosse por isso, possivelmente algumas polêmicas que atravessam a recepção de Origens do totalitarismo seriam minimizadas e não teriam eclipsado a perspectiva inovadora ali adotada, ${ }^{59}$ assim como suas agudas reflexões posteriores no âmbito da historiografia.

A redação do livro ocupou a reflexão de Arendt entre os anos de 1945 e 1949, tal como ela revela no prefácio à edição de 1966. Em 1946, no ensaio A imagem do inferno, Arendt (2008b, p. 227) já prenuncia as dificuldades que espera encontrar, afirmando:

A história humana nunca conheceu um episódio mais difícil de ser narrado. A monstruosa igualdade na inocência [numa clara referência aos reclusos nos campos de concentração], que é seu tema principal, destrói a própria base em que se produz a história - a saber, nossa capacidade de compreender um acontecimento, por mais distantes que estejamos.

O fenômeno totalitário aparece a ela, portanto, como um problema relativo à própria natureza do conhecimento, à capacidade de compreender determinado fenômeno. O fato é que "vários pressupostos teóricos importantes" para a compreensão de Origens do totalitarismo "permanecem implícitos e como que escondidos do leitor [...], o que multiplica os malentendidos e as controvérsias" (DUARTE, 2001, p. 61) que a obra suscita. Há pistas, como essa sobre a dificuldade da narrativa, que esclarecem um pouco melhor o percurso analítico de Arendt, bem como suas hesitações diante do tema que a absorvia naqueles anos, ainda que essas pistas não se encontrem presentes no prefácio de 1951. Parte delas são algumas notas e cartas enviadas a Mary Underwood, da editora Houghton Mifflin, em fins de 1944 (ou início de 1945), quando Arendt apresenta o primeiro esboço do que viria a ser Origens do totalitarismo, que àquela altura tinha por título Os elementos da vergonha: anti-semitismo, imperialismo, racismo ou ainda o dramático Os três pilares do inferno. ${ }^{60}$ Respondendo a Underwood sobre como pretendia interligar as três partes da obra, Arendt revela suas dificuldades:

[...] eu me mantive afastada do escrever histórico no sentido estrito porque sinto que essa continuidade é justificada apenas se o autor quer preservar, entregar o seu tema aos cuidados e à memória de gerações futuras. $\mathrm{O}$ escrever histórico, nesse sentido, é sempre uma justificação suprema do que aconteceu (apud YOUNG-BRUEHL, 1997, p. 194).

\footnotetext{
${ }^{58}$ Cf. DISCH, 2012, p. 79.

${ }^{59}$ Carol Brightman (1995, p. 19), que organizou e publicou a correspondência entre Arendt e sua amiga Mary McCarthy, pondera que "a exposição cuidadosa das idéias não era o forte de Arendt - ela sabia disso, e o tolerava a um ponto que às vezes incomodava [a amiga e colaboradora Mary] McCarthy".

${ }^{60}$ Cf. YOUNG-BRUEHL, 1997, p. 193.
} 
Despontam aqui dois temas caríssimos aos historiadores. O primeiro é a reflexão sobre a própria escritura da história - e que talvez Arendt antecipe ${ }^{61}-$, ou de como o próprio ato de escrever implica um exercício de compreensão para o autor. O segundo é a recusa de Arendt da ideia de continuidade, uma vez que pretende apresentar seu tema não como um desenvolvimento necessário de um processo de evolução natural ou histórico e, ao mesmo tempo, não pretende celebrar seu tema principal, isto é, justificá-lo. Assim, justificar as três partes de Origens ou apenas condená-las parece a Arendt não só inadmissível, mas mesmo impossível, pois a relação que ela estabelece entre imperialismo, anti-semitismo e totalitarismo não é de necessidade, mas de possibilidade, ou seja, os três em si mesmos não são causa de nada, mas elementos que acabaram por se cristalizar nos regimes totalitários. $\mathrm{O}$ anti-semitismo e o imperialismo não foram fenômenos exclusivos da Alemanha nazista e da União Soviética stalinista. Marcaram presença em vários outros países europeus e nem por isso se cristalizaram num regime totalitário.

Arendt ainda revela a Underwood que:

A mera abordagem polêmica também foi evitada. Esta só é permitida à medida que o autor pode voltar para o terreno firme dos valores tradicionais que são aceitos sem questionamento, sobre o qual os julgamentos podem ser formados... Não acredito mais que qualquer tradição em si mesma possa oferecer-nos tal base. Uma abordagem polêmica, em meu caso, teria sido simplesmente cínica e certamente não convincente (apud YOUNGBRUEHL, 1997, p. 194).

Não poder "voltar para o terreno firme dos valores tradicionais", da autoridade da tradição, significa igualmente que o totalitarismo desafia o pensador quanto à sua capacidade de ajuizar tal fenômeno. Se o fenômeno totalitário instaura uma ruptura na tradição, isso não significa que o pensador a ignore. Antes, que ele a critica. As mesmas inquietações aparecem em $1953^{62}$ quando Arendt consente, a convite da Review of Politics, em responder a uma resenha do filósofo político alemão Eric Voegelin - exilado como ela - sobre Origens do totalitarismo, seguida de um comentário final do filósofo. ${ }^{63} \mathrm{Em}$ janeiro daquele ano, a revista

\footnotetext{
${ }^{61}$ Entre os historiadores, a questão foi posta em debate, ou mais propriamente retomada, com a publicação da obra A escrita da história, por Michel de Certeau, em 1975, coincidentemente, ano da morte de Hannah Arendt. O debate abarca uma ampla bibliografia, da qual se destacam: BURKE, 1992; CARDOSO; VAINFAS, 1997 (especialmente o ensaio introdutório de Flamarion, intitulado História e paradigmas rivais); CARR, 1996; LE GOFF et al., 1986; DOSSE, 2003; FEBVRE, 1974; VEYNE, 1983; LE GOFF, 1990.

${ }^{62}$ ARENDT, 2008b, 417-424.

${ }^{63}$ Eric Voegelin figura na bibliografia de Origens do totalitarismo com três trabalhos, sendo dois livros e um artigo. Na nota $\mathrm{n}^{\circ} 3$ da página 189, Arendt (1989) diz: "A melhor análise histórica do pensamento racista, apresentada sob a forma de 'história das idéias', é de Eric Voegelin. (Rasse und Staat [Raça e Estado], Tuebingen, 1933)".
} 
publica a resenha de Voegelin, a réplica de Arendt e o comentário final do filósofo. A réplica revela outras pistas e hesitações em torno da narrativa de Origens do totalitarismo:

[...] se de um lado sinto que, dentro das inevitáveis limitações de um estudo histórico e uma análise política, me fiz clara o suficiente sobre certas perplexidades gerais que surgiram com o pleno desenvolvimento do totalitarismo, por outro lado sei que deixei de explicar o método particular que empreguei, e de expor uma abordagem bastante incomum [...] Uma das dificuldades do livro é que ele não pertence a nenhuma escola, e não usa quase nenhuma ferramenta oficialmente reconhecida ou oficialmente controvertida (ARENDT, 2008b, p. 418, grifo nosso).

E um pouco adiante:

O problema com que me deparava de início era simples e, ao mesmo tempo, desconcertante: toda historiografia é necessariamente salvação e com frequência justificação; isto porque o homem teme que possa esquecer e luta por algo além de uma rememoração (p. 418).

Se, para Arendt, toda obra histórica é salvação e justificação, o que se pode salvar ou justificar numa obra que pretende compreender o fenômeno totalitário e suas fábricas de extermínio? Equação difícil, já que a "própria base em que se produz a história - a saber, nossa capacidade de compreender um acontecimento" - foi destruída. Ora, uma argumentação convencional que lançasse mão da linguagem consagrada das Ciências Sociais e da História teria o efeito de contradizer o tema fundamental de Arendt, que consiste em compreender o totalitarismo, algo incompreensível em termos usuais. Isso significa que a compreensão do totalitarismo implica também um problema de linguagem. Por isso, conforme a aguda percepção de Lisa Disch, Arendt usa recursos literários como a metáfora, o oximoro e a hipérbole, que permitem expressar as incompreensíveis ações dos regimes totalitários numa linguagem que se ajusta melhor aos seus dilemas analíticos e à forma de tecer sua narrativa. ${ }^{64}$ Que os testemunhem os oximoros fábricas de extermínio, fábricas de morte, fabricação de cadáveres como ferramentas não reconhecidas oficialmente "ou oficialmente controvertida", como ela diz a Voegelin. O que Arendt pretende ao introduzir essa estratégia na trama da narrativa é mostrar que o fenômeno totalitário viola o senso comum. Trata-se de "expor uma abordagem bastante incomum" numa linguagem que "dramatiza a loucura dos campos, pois só pode soar absurdo uma fábrica que exista para produzir a morte” (DISCH, 2012, p. 87).

\footnotetext{
${ }^{64}$ Cf. DISCH, 2012, p. 87.
} 
Também não convém a Arendt narrar de forma destrutiva - como observa em obras ${ }^{65}$ sobre o anti-semitismo -, pois isso lhe parece contraditório com o sentido consagrado da escrita da história, que é o de salvar, perenizar. E prossegue na réplica: “A saída foi se apegar, por assim dizer, aos judeus, fazer deles o objeto a ser conservado. Mas isso não resolvia o problema, pois olhar os fatos apenas do lado da vítima resultava numa apologética - o que, naturalmente, não é história" (ARENDT, 2005b, p. 418).

Aqui se ouvem os ecos de Heródoto e Tucídides. Não como modelos a serem seguidos, o que parece inviável, mas na busca por uma forma narrativa que não se reduza a vitimizar os judeus - o "objeto a ser conservado"; nem cedendo à tentação de simplesmente condenar o anti-semitismo, o imperialismo e o totalitarismo. Aos olhos de Arendt, porém, persiste a grandeza do modelo sine ira et studio - sem cólera, nem parcialidade ${ }^{66}$ - de que as obras de Heródoto e Tucídides são exemplos notáveis, pela objetividade e pela imparcialidade que ambos alcançaram ao prestar louvor tanto aos gregos como aos persas (Heródoto), e não menos aos atenienses do que aos espartanos (Tucídides). Entretanto, o modelo antigo de imparcialidade e objetividade parece trair a realidade que Arendt quer compreender. ${ }^{67}$ Assim, Homero, Heródoto e Tucídides servem para ela refletir sobre que espécie de imparcialidade e objetividade é possível diante da falência da moderna consciência historiográfica em face do Holocausto. Conforme diz na réplica a Voegelin,

[...] meu primeiro problema era como escrever historicamente sobre algo - o totalitarismo - que eu não queria preservar, mas pelo contrário, me sentia empenhada em destruir. [...] Houve quem o elogiasse [o livro] por julgá-lo apaixonado, e quem o criticasse por considerá-lo sentimental. As duas avaliações me parecem um tanto deslocadas. Rompi de maneira muito consciente com a tradição do sine ira et studio, cuja grandeza me parecia incontestável, e para mim foi uma necessidade metodológica intimamente ligada ao meu tema específico (ARENDT, 2005b, p. 418-419).

\footnotetext{
${ }^{65}$ A questão aparece no ensaio A imagem do inferno, na parte relativa à resenha da obra The black book: the nazi crime against the jewish people, publicada em Commentary, em 1946, e incluída na coletânea Compreender: formação, exílio e totalitarismo (ensaios). Quanto ao método empregado pelos autores, Arendt (2005b, p. 226) diz: "O método empregado foi o terror cumulativo".

${ }_{67}^{6}$ A tradução foi sugerida por Elias Thomé Saliba quando do exame de qualificação. A frase é de Tácito.

67 A resenha de Voegelin, além de apontar lacunas na obra de Arendt, percebe nela um parentesco com Tucídides que convém assinalar: "La forma en que la autora tensa su arco desde los hechos del presente hasta sus orígenes en la consolidación del Estado nacional evoca recuerdos lejanos de ese otro gran gesto con que Tucídides tensó su arco desde el movimiento catastrófico de su tiempo (la gran kínesis) hasta sus orígenes en el momento en que, tras las guerras médicas, Atenas emerge como polis. La emoción en estado puro hace del intelecto un instrumento sensible para reconocer y seleccionar los hechos relevantes; y si la pureza del interés humano no se deja contagiar de partidismo, el resultado ha de ser un estudio histórico de rango notable, cual es el caso de esta obra cuyas partes sustantivas están llamativamente libres de sinsentido ideológico" (ARENDT; VOEGELIN, 2002, p. 6).
} 
O rompimento a que Arendt faz menção está no fato de que, para ela, "descrever os campos de concentração sine ira não é ser 'objetivo', e sim desculpá-los”. Daí o recurso à metáfora do inferno que ela aplica aos campos de concentração, o que alguns críticos consideram uma prova de pouca objetividade. A esse respeito, Birulés (1997, p. 34) sublinha que "escribir sin cólera sería eliminar del fenómeno una parte de su naturaleza, una de sus cualidades inherentes. Frente al totalitarismo, la indignación o la emoción no oscurece nada antes bien es una parte integrante del objeto". Numa resenha de 1946, por meio de um insight que lembra a descrição da peste por Tucídides - por evocar um saber que permaneça na memória dos homens ${ }^{68}$-, Arendt (2005b, p. 229, grifo nosso) adverte:

A história real do inferno construído pelo nazismo é de absoluta necessidade para o futuro. Não só porque esses fatos alteraram e envenenaram o próprio ar que respiramos, não só porque agora povoam nossos sonhos à noite e ocupam nossos pensamentos durante o dia - mas também porque se tornaram a experiência fundamental e fundamental desgraça de nossos tempos.

Por fim, ela reconhece na réplica - já o fizera antes em seu diário de pensamento $(\text { Denktagebuch })^{69}$ - o equívoco a que o título do livro induz. Diz que o "livro não trata de fato das 'origens' do totalitarismo [...] mas apresenta uma exposição histórica dos elementos que se cristalizaram no totalitarismo" (ARENDT, 2005b, p. 419, grifo nosso). Como sublinha Disch (2012, p. 89), o termo origens "es un concepto temporal que implica una narrativa evolutiva sobre acontecimientos causalmente relacionados", isto é, vai na contramão, como se viu, das notas que Arendt escreveu a Mary Underwood. Os elementos, ao contrário das causas, sinalizam um ponto de ruptura com as narrativas históricas que tratam da evolução contínua de um acontecimento. O conceito de cristalização - que Arendt apenas esboça indica que o totalitarismo foi possível graças a uma coincidência de elementos que não estão necessária ou causalmente conectados, mas cuja intersecção não foi simplesmente um azar histórico.

Se a réplica a Eric Voegelin ajuda a esclarecer opções que Arendt tomou perante as perplexidades enfrentadas com a compreensão e a narrativa de Origens do totalitarismo, não

\footnotetext{
${ }^{68}$ Diz Tucídides (1982, p. 102-3) a respeito da peste: “[...] descreverei a maneira de ocorrência da doença, detalhando-lhe os sintomas, de tal modo que estudando-os, alguém mais habilitado por seu conhecimento prévio não deixe de reconhecê-la se algum dia ela voltar a manifestar-se, pois eu mesmo contraí o mal e vi outros sofrendo dele".

${ }^{69}$ Arendt (2011, p. 95, grifo nosso) faz uma breve anotação em seu diário em junho de 1951: "El título de mi libro es completamente falso; habría de ser: The Elements of Totalitarianism". A edição original dos diários de pensamento é alemã: Denktagebuch, 1950 bis 1973 (Edição de Ursula Ludz e Ingeborg Nordmann. Munique: Piper, 2002). Seguimos a edição em espanhol: Diario filosófico: 1950-1973.
} 
desfaz por completo o estranhamento com a obra que, mesmo ante as mudanças realizadas na segunda (1958) e na terceira (1966) edições - além de adições e supressões, Arendt acrescentou prefácios a cada uma das três partes do livro, num claro reconhecimento de que a costura das partes não estava clara aos leitores -, ainda desafia seus intérpretes.

\subsection{Conhecimento e compreensão: verdade e sentido}

Ainda em 1953, Arendt publica na Partisan Review o ensaio Compreensão e política, em que insiste na ruptura da tradição: “O problema da sabedoria do passado é que ela [...] morre em nossas mãos tão logo tentamos aplicá-la de forma honesta às experiências políticas centrais de nossos tempos" (ARENDT, 1993a, p. 41). E a experiência política central que a geração de Arendt viveu, o acontecimento extraordinário, é o fenômeno totalitário: “O próprio acontecimento requer compreensão, autoriza-a" (AMIEL, 1997, p. 49). Convém ressaltar que As dificuldades da compreensão ${ }^{70}$ foi o título original que Arendt havia pensado para Compreensão e política. Talvez ele expressasse melhor suas intenções, já que a possibilidade de se compreender um fenômeno como o totalitarismo é colocada sob suspeição: "Se é verdade [...] que estamos diante de algo que destruiu nossas categorias de pensamento e os padrões de nosso juízo, não será um caso perdido a tarefa de compreender? Como podemos medir o comprimento se não temos um metro?” (ARENDT, 1993a, p. 44).

O que o ensaio deixa entrever, mas o prefácio de 1951 não esclarece, é a distinção que Arendt começa a aplicar entre categorias fundamentais que aparecem em seus textos em pares contrastantes - conhecimento e compreensão, verdade e sentido, cognição e pensamento - e ecoam a distinção kantiana entre intelecto (verstand) e razão (vernunft), tema que abordará mais densamente em A vida do espírito: $:^{71}$ "O intelecto (Verstand) quer aprender o que é dado aos sentidos, mas a razão (Vernunft) quer compreender o seu sentido" (ARENDT, 1999, p. 68). Aqui, ainda que apontando para a mesma distinção, as categorias empregadas são outras:

Conhecimento e compreensão não são a mesma coisa, mas interligam-se. A compreensão baseia-se no conhecimento e o conhecimento não pode se dar sem que haja uma compreensão inarticulada, preliminar. [...] A compreensão

\footnotetext{
${ }^{70} \mathrm{Na}$ Biblioteca do Congresso Americano, onde se encontra boa parte dos manuscritos de Arendt, existem diferentes versões desse ensaio. Jerome Kohn esclarece o teor de tais papéis no prefácio de Compreender: formação, exílio e totalitarismo (ARENDT, 2008b, p. 16-7; ver também p. 356, 469-472).

${ }^{71} \mathrm{Na}$ seção 23 de A condição humana, intitulada A permanência do mundo e a obra de arte, Arendt também aborda a questão. Em vez de utilizar razão, fala em pensamento, e, no lugar de intelecto, emprega cognição. O pensamento tem um fim em si mesmo, ao passo que a cognição "sempre persegue um fim definido" (ARENDT, 2010a, p. 213).
} 
preliminar, que está na base de todo conhecimento, e a verdadeira compreensão, que o transcende, têm isso em comum: conferem significado ao conhecimento (ARENDT, 1993a, p. 42, grifo nosso).

Se a compreensão confere significado ao conhecimento - fato que também a torna aparentada à faculdade do pensar e da imaginação -, o que sucedeu historicamente para que os homens deixassem de buscar o significado dos fenômenos e perdessem a capacidade de compreender? Ora, Arendt não se cansa de repetir que todo pensamento surge da experiência, mas entende que nenhuma experiência é capaz de adquirir significado se não se submete às operações da imaginação e do pensamento. A necessidade da razão não está guiada pela busca da verdade, mas pela busca do significado. Conforme ela sublinha: "Esperar que a verdade provenha do pensar significa que confundimos a necessidade de pensar com o impulso para conhecer" (ARENDT, 1999, p. 72). Birulés (2007, p. 203) percebe bem o alcance da distinção ao comentar:

$\mathrm{Al}$ distinguir el pensar del conocer, [Arendt] no trata de negar el conocimiento, sino que intenta separarlo del pensar y no exigir los mismos resultados ni aplicar los mismos criterios a estas dos faculdades, como lo ha hecho buena parte de la filosofia moderna y contemporánea cuando ha interpretado el significado según el modelo de la verdad.

A compreensão, diferentemente do conhecimento científico, também é "a maneira especificamente humana de estar vivo", porque necessitamos entrar em acordo com o mundo "à medida que tentamos nos reconciliar com o que fazemos e com o que sofremos" (ARENDT, 1993a, p. 40), e isso significa que o único resultado que se pode esperar da compreensão é o sentido. O mundo não se torna humano apenas quando homens e mulheres decidem agir de forma livre e contingente, mas também, e especialmente, por debaterem o sentido que o mundo possa ter, ${ }^{72}$ por "imaginar [e comunicar] aquilo que realmente aconteceu" (ARENDT, 1991, p. 117). Arendt (1993a, p. 45) recorda uma passagem de Paul Valéry - para ela, "o espírito mais lúcido entre os franceses" e o primeiro a detectar a derrota “do senso comum no mundo moderno". Nas palavras de Valéry, ocorrera "uma espécie de insolvência da imaginação e uma bancarrota da compreensão” (apud ARENDT, 1993a, p. 45). O declínio de ambas significa que, ao sermos privados de um mundo comum, vimo-nos igualmente privados de um senso comum, "aquela parcela de sabedoria herdada que todos têm em comum em qualquer civilização" (p. 45-6) e que nos permite compreender o sentido das coisas e nos reconciliar com um mundo em que o terror totalitário foi possível.

\footnotetext{
${ }^{72}$ Cf. ROVIELLO, 1997, p. 72.
} 
A Arendt interessa pensar as implicações advindas da perda do senso comum. Ela intui que o fenômeno totalitário possui uma lógica que repousa na engenhosa capacidade com que deturpa certas hipóteses científicas - "tal como a sobrevivência dos mais aptos, na biologia, ou a sobrevivência da classe mais progressista, na história” (p. 48) - numa premissa lógica, autoevidente, aplicável ao curso dos acontecimentos humanos. Ela avalia que,

[...] onde quer que o senso comum, o sentido político por excelência, deixe de atender nossa capacidade de compreensão, é muito provável que aceitemos a lógica como seu substituto, pois a capacidade de raciocínio lógico é também comum a todos nós (p. 48).

Ocorre que o senso comum e a lógica não se equivalem de forma alguma. O senso comum não pode, como pode a lógica, prescindir de um mundo comum. Ele representa aquela "fé natural no mundo tal como aparece, como a faculdade que nos permite inserir-nos e orientar-nos no mundo, fazer dele a nossa casa" (ROVIELLO, 1997, p. 123). Representa, ainda, aquela parcela de uma sabedoria herdada que agora se evadiu e, por fim, diz respeito também a um sentido comum (espécie de sexto sentido) que ajustava todos a uma mesma realidade fenomênica, a uma mesma experiência sensível que lhes permite olhar o mesmo a partir de sua singularidade.

Arendt sublinhará que os processos lógicos funcionam perfeitamente bem, a despeito de qualquer realidade. Eles podem "reivindicar uma confiabilidade totalmente independente do mundo e da existência de outras pessoas" (ARENDT, 1993a, p. 48) e, como tal, possuem o poder compulsório de persuadir. Os nazistas, afinal, não foram capazes de persuadir os alemães de que o mundo seria melhor sem a presença dos judeus? E o aparato stalinista não foi igualmente perspicaz em persuadir os soviéticos de que era necessário livrar-se das classes em extinção?

É contra esse tipo de operação lógico-causal que ela dirige sua crítica, apesar da chocante afirmação de que "a causalidade é [...] uma categoria totalmente estranha e falseadora no que diz respeito às ciências históricas" (ARENDT, 1993a, p. 49). De fato, ela nunca pretendeu negar a existência da causalidade, mas sim alertar contra os perigos de se entregar à lógica de um processo dedutivo do tipo causa-efeito que necessariamente deduz de uma premissa - a sobrevivência dos mais aptos (arianos) ou da classe mais progressiva (proletariado) - tal ou qual conclusão. O que Arendt parece acentuar, como nota Amiel (1997, p. 49-50), é que o "acontecimento ou a ação, como liberdade, formam descontinuidade e portanto não conhecem nenhuma causa no sentido estrito do termo." 
A compreensão é também o gesto de resistir a uma realidade inaudita, por nos faltarem os instrumentos ordinários para compreendê-la. No prefácio de 1951, Arendt (1989, p. 12) sublinha: "Compreender significa, em suma, encarar a realidade sem preconceitos e com atenção, e resistir a ela - qualquer que seja". Ainda no mesmo prefácio, ela recorda o fato chocante de que fenômenos desprovidos de importância na política mundial, como a questão judaica e o anti-semitismo, acabaram se transformado em agentes catalisadores do movimento nazista, da Segunda Guerra e, por fim, das fábricas de extermínio. Mas apenas sugere, numa ligeira passagem, o vínculo que estabelecerá nos anos seguintes entre compreensão e sentido, quando diz acreditar na possibilidade de encarar a "irritante incompatibilidade entre o real poderio do homem moderno [...] e a sua incapacidade de viver no mundo que o seu poderio criou, e de lhe compreender o sentido" (p. 12, grifo nosso).

Em 1959, numa palestra proferida em Hamburgo, Arendt (1991, p. 33) sublinhou: "Nenhuma filosofia, nenhuma análise, nenhum aforismo, por muito profundos que sejam, podem comparar-se, na intensidade e na riqueza de sentidos, a uma história bem contada". A singeleza do enunciado soaria muitíssimo bem caso estivesse onde mais se desejaria encontrálo: no prefácio de Origens do totalitarismo. Mas o fato é que não está lá, mas no ensaio sobre Lessing. Como leitora de Isak Dinesen (1885-1963), Arendt (1991, p. 117) aprendera que

[...] o mundo está cheio de histórias [...] que só estão a espera de ser contadas, e o motivo que geralmente ficam por contar é [...] a falta de imaginação - pois só se formos capazes de imaginar aquilo que realmente aconteceu, de o repetir imaginariamente, é que veremos as histórias, e só se tivermos a paciência de as contar e voltar a contar [...] é que conseguiremos contá-las bem.

Não faltou imaginação a Arendt em seu esforço de narrar uma história do totalitarismo. Ela não o fez com a pretensão de desfazer, tampouco dominar o passado. É provável que seu ânimo por narrar tenha brotado da possibilidade de se reconciliar com um mundo onde o totalitarismo foi possível. Há uma passagem no ensaio sobre Lessing que bem poderia se aplicar ao gesto arendtiano de compreender o totalitarismo:

Na medida em que é possível, o "domínio" do passado consiste em relatar o que aconteceu; mas nem essa narração, que dá forma à história, tem o poder de resolver os problemas e aliviar o sofrimento; não domina o que quer que seja de uma vez por todas. [...] É ao poeta, num sentido muito geral, $e$ ao narrador, num sentido muito particular, que incumbe a tarefa de pôr em movimento esse processo de narração e de nos implicar nele (ARENDT, 1991, p. 31-2, grifos nossos). 
Ora, se é fato que, de tempos em tempos, os historiadores procuraram persuadir seus leitores de que aquilo que narravam era digno de ser narrado, Arendt poderia muito bem lhes fazer companhia. Com a diferença de que não pretende justificar nada, mas tão somente implicar e deixar que o leitor julgue por si mesmo.

Para ela, os recursos legados pela historiografia, desde que a História começou a se afastar da tradição da epopeia homérica, não bastam para se compreender e revelar a novidade totalitária, pois "essa tentativa de compreender o presente à luz do passado se mostrou infrutífera" (ARENDT, 2008b, p. 241). Convém lembrar que Heródoto, a um só tempo, segue e se afasta do caminho aberto por Homero; que Tucídides apropria-se de ambos, mas deles também se afasta. Enfim, se há um caráter cumulativo na tradição, ela também pode ser reinventada. Em outras palavras, a narrativa histórica, embora tenha atrás de si uma longa tradição, sempre admite a inovação. Como nota Arendt (1993a, p. 49),

Sempre que ocorre um evento grande o suficiente para iluminar seu próprio passado a história acontece. Só então o labirinto caótico dos acontecimentos passados emerge como uma estória que pode ser contada, porque tem um começo e um fim. O que o evento iluminador revela é um começo no passado que até então estivera oculto; aos olhos do historiador, o evento iluminador só pode aparecer como um final para esse recém-descoberto início.

Partindo do pressuposto de que a tradição - "o fio que nos guiou com segurança através dos vastos domínios do passado" (ARENDT, 1992, p. 130) - rompeu-se, como se estrutura a análise histórica arendtiana e por quais caminhos ela efetivamente rompe (e por quê) com o legado da moderna consciência historiográfica? Enfim, que papel Arendt reserva à história em seu pensamento político? Se a história (history) é o conjunto das muitas histórias (stories) e se a compreensão, tal como ela sublinha, "torna-se o outro lado da ação" (ARENDT, 1993a, p. 52), talvez convenha recuperar o sentido da ação na polifonia entre antigos e modernos. Primeiro os antigos. No capítulo seguinte, os modernos.

\subsection{Mortal, natal e apátrida}

Momigliano (2004, p. 60) sublinha que "Heródoto estava preocupado com o caráter efêmero das ações humanas. Assim como muitos outros gregos, ele acreditava que a memória das ações passadas era o único (e imperfeito) remédio que o homem tinha contra a sua própria mortalidade". Essa condição mortal de todos os homens e a incomensurável perplexidade que isso causa é resumida por Arendt (2010a, p. 307) de forma lapidar quando ela diz que "os 
homens, embora tenham de morrer, não nascem para morrer, mas para começar". Passagem de inspiração claramente agostiniana, assinala o estreito vínculo presente na tríade natalidadeação-mortalidade no pensamento político de Arendt. ${ }^{73}$ No capítulo anterior, enfatizou-se que a recuperação do sentido da ação (práxis) como se concebia na Atenas pré-filosófica - à maneira de uma hipótese - tem em Auschwitz seu impulso. Descongelar conceitualmente o sentido atribuído pelos gregos à ação, portanto, não visa a reatar o fio rompido da tradição, mas a clarificar uma experiência do passado que a compreensão do presente solicita.

Ser mortal não é o mesmo que ser expulso da humanidade por um regime, o nazista ou o de Stálin, que se arvora em decidir quem é digno ou indigno de viver entre os homens. Nessa situação, a condição mortal do ser humano deixa de habitar a imprevisibilidade do futuro para antecipar-se numa condenação presente. É o caso de Arendt e de todos os judeus como ela atingidos por essa condenação ao se tornarem inimigos por excelência do regime nazista. Isso contradiz a noção que a tradição legou de inimigo em todas as guerras passadas. Agora, dirá Arendt (2008b, p. 361), é a própria lei do movimento da natureza ou da história que

[...] aponta os inimigos da humanidade e não admite [como nas épocas passadas] a interferência de nenhuma ação livre dos simples seres humanos [...] "culpado" é aquele que fica no caminho do terror, ou seja, aquele que de bom grado ou não, retarda o movimento da Natureza [as raças inferiores] ou da História [as classes moribundas].

Assim, os campos de concentração e os progroms surgem na cena histórica como algo inaudito, que afronta a compreensão ordinária do que seja um inimigo. Para o caso do nazismo, o caráter anti-utilitário dos campos, atentando contra a escassez inerente a um tempo de guerra, é frequentemente lembrado por Arendt em Origens do totalitarismo. Não é, entre outras razões, porque a esse inimigo objetivo foi impossibilitada toda e qualquer ação, na forma de atos ou palavras, que Arendt se vê impelida a salvá-lo? Vê-se que já nem se trata mais de salvar as ações humanas de sua inerente fragilidade, ${ }^{74}$ por se desvanecerem sem nada deixar atrás de si. Antes, Arendt parece empenhada em salvar a própria fragilidade humana.

Nessa perspectiva, a obra Origens do totalitarismo assume o caráter de um monumento como aqueles erguidos ao soldado desconhecido após a Primeira Guerra Mundial. O monumento procura compensar a ausência de um corpo reconhecível, é um substituto para o ritual de sepultamento, uma forma de prestar ao soldado não identificado as

\footnotetext{
${ }^{73}$ Cf. BIRULÉS, 1997, p. 15.

${ }^{74}$ Arendt observa (2010a, p. 10): "A ação, na medida em que se empenha em fundar e preservar corpos políticos, cria a condição para a lembrança [remembrance], ou seja, para a história".
} 
devidas honras pela morte em combate, fazendo-lhe a justa memória. Seu sentido é o de fornecer alguma resposta ao problema da mortalidade, alguma espécie de reconciliação com a realidade. É uma recusa "a se resignar ao fato brutal de que o agente da guerra havia sido realmente ninguém [...] a todos aqueles a quem a guerra fracassou em tornar conhecidos, roubando-lhes, com isso, não suas realizações, mas sua dignidade humana" (ARENDT, 2010a, p. 226).

A narrativa de Origens do totalitarismo coloca Arendt perante um problema semelhante. Ali não se trata da ausência de um corpo (ou de milhões deles) ou de corpos irreconhecíveis, mas de encontrar um sentido, se é que ele pode vir a existir, para a morte daqueles milhões de pessoas. Anos mais tarde, Arendt formularia o problema nos seguintes termos políticos: por que deve haver o alguém ao invés do ninguém $?^{75}$ Insisto: a ninguendade que se produz em Auschwitz conduz Arendt (1989, p. 503) aos gregos:

\begin{abstract}
Mesmo em seus períodos mais negros, o mundo ocidental deu sempre ao inimigo morto o direito de ser lembrado, num reconhecimento evidente de que todos somos homens (e apenas homens). Até mesmo Aquiles providenciou os funerais de Heitor [...]. Os campos de concentração, tornando anônima a própria morte e tornando impossível saber se um prisioneiro está vivo ou morto, roubaram da morte o significado de desfecho de uma vida realizada. Em certo sentido, roubaram a própria morte do indivíduo, provando que, doravante, nada - nem a morte - lhe pertencia e que ele não pertencia a ninguém. A morte apenas selava o fato de que ele jamais havia existido.
\end{abstract}

Essa perspectiva se apoia no fato de que a novidade radical do totalitarismo corrompeu até mesmo os conceitos ordinários de ação, mortalidade e imortalidade legados pela tradição. E como é comum a Arendt recuperar o sentido original de um conceito ${ }^{76}$ quando ele se esvaneceu, ela volta às fontes gregas (a poesia épica e a historiografia de Heródoto e Tucídides) e romanas (Cícero, Agostinho) para iluminar uma situação presente que desafia sua compreensão. Birulés (1997, p. 9) sublinha que, para Arendt,

En el lenguaje hay "pensamiento congelado" que el pensar debe descongelar cuando quiere averiguar el sentido original. Así, trabaja aislando conceptos, siguiéndoles la pista, enmarcándolos, de manera que, en sus manos, el acto de teorizar tiene algo que ver con reencontrar, recuperar y destilar un sentido que se ha evaporado: se traduce, pues, en recuerdo.

\footnotetext{
${ }^{75}$ Numa anotação de seu diário, em março de 1955, Arendt (2011, p. 504) escreve: ¿Por qué hay en absoluto alguien y no más bien nadie? Ésa es la pregunta de la política".

76 "Ela [Arendt] chamou seu método filosófico de 'análise conceitual'; sua tarefa era de descobrir 'de onde vêem os conceitos'. Com a ajuda da filologia ou da análise lingüística, retraçava o caminho dos conceitos políticos até as experiências históricas concretas e geralmente políticas que davam origem a tais conceitos. Era então capaz de avaliar a que ponto um conceito se afastara de suas origens e mapear a miscelânea de conceitos através do tempo, marcando pontos de confusão lingüística e conceitual. Ou, dizendo de outra maneira: ela praticava uma espécie de fenomenologia" (YOUNG-BRUEHL, 1997, p. 286).
} 
Convém insistir que esse reencontro com a Antiguidade não se presta a restaurar nenhum elo perdido, mas a iluminar o passado à luz do presente e este à luz daquele, pois, como diz Tocquevillle, numa passagem sempre lembrada por Arendt (1992, p. 32): "Desde que o passado deixou de lançar sua luz sobre o futuro, a mente do homem vagueia nas trevas". Das trevas de Auschwitz até a luz dos gregos, ela busca alguma orientação para pensar os tempos sombrios, como nota na carta de 30 de maio de 1946 a Gertrud Jaspers, uma judia como ela: "Me ha emocionado mucho que hable usted de 'nuestro' problema" [a questão judia]. E, um pouco adiante, referindo-se à situação alemã: "Pero yo tampoco sé cómo se puede soportar vivir allí como judío, en un entorno que ni siquiera se digna a hablar de ‘nuestro' problema, que hoy son nuestros muertos. Sólo sé que sería bueno poder hacerlo" (ARENDT, 2010b, p. 179).

\subsubsection{Mortalidade do homem e imortalidade da natureza}

Dois fragmentos da Odisséia ajudam a entrar no tema da mortalidade - para Aristóteles (apud ARENDT, 1999, p. 156), "o maior de todos os males" - e com ele avançar nas concepções gregas de natureza e de história, bem como na relação que mantêm entre si, pois, para Arendt (1992, p. 72), “a distinção entre a mortalidade dos homens e a imortalidade da natureza, entre as coisas feitas pelo homem e as coisas que existem por si mesmas, era o pressuposto tácito da Historiografia". O primeiro fragmento é quando Ulisses, na corte dos feácios, ante a pergunta que se faz a todo recém-chegado - Quem és? -, responde ao rei Alcínoo não ser senão um mortal. O segundo é o episódio em que a deusa Calipso, "desejosa de dar-lhe [a Ulisses] o dom da imortalidade, desde que ele permaneça com ela", tem a oferta recusada:

Perdoa-me, responde ele a Calipso, que lhe oferece a imortalidade, eu sei [...] que a sapientíssima Penélope/ não oferece aos olhos nem a tua beleza, nem tua estatura: / ela é mortal, tu ignoras a idade e a morte. / Entretanto, espero, desejo a todo momento / me encontrar em minha casa e ver o dia do retorno (apud HARTOG, 2004, p. 33).

Para Hartog, a passagem revela, pela primeira vez, a "recusa heróica da imortalidade". Sobre os dois fragmentos, que se retenham três pontos. O primeiro, na resposta ao rei Alcínoo, é a consciência de Ulisses quanto à condição humana da mortalidade; depois, a 
recusa de Ulisses à oferta da deusa Calipso; por fim, a relação entre essa recusa e o desejo de Ulisses - "me encontrar em minha casa".

Quanto ao primeiro ponto, ao responder ao rei não ser "senão um mortal", Ulisses revela a contrapartida da concepção grega de natureza, isto é, daquelas coisas que não foram trazidas à existência pelos homens, mas que existem por si mesmas e, por essa razão, são imortais. Como Arendt (1992, p. 71) sublinha,

Incrustada em um cosmo em que todas as coisas eram imortais, foi a mortalidade que se tornou a marca distintiva da existência humana. Os homens são "os mortais", as únicas coisas mortais que existem, pois os animais existem tão-somente enquanto membros de espécies e não como indivíduos. $^{77}$

O segundo ponto emerge do primeiro. Se o traço que distingue a condição humana no cosmo é a mortalidade, é porque a percepção do homem grego acerca da natureza e dos deuses é a de que são imortais. Ora, o que mais pode o homem, em sua singularidade - de não ser, como os animais, membro de uma espécie que em alguma medida também porta esse serpara-sempre da natureza, conforme Aristóteles -, senão aspirar a essa imortalidade que os deuses e a natureza conseguem sem esforço? "Visto serem as coisas da natureza sempre presentes, é improvável que sejam ignoradas ou esquecidas; e, desde que elas existem para sempre, não necessitam de recordação humana para sua existência futura" (ARENDT, 1992, p. 70).

Assim, como compreender que Ulisses recuse a oferta da deusa Calipso? Vidal-Naquet (2002, p. 34) argumenta que a recusa de Ulisses, "preferindo permanecer humano e reencontrar Penélope" é uma "opção pela humanidade" e é ela que dá significado ao poema. Afinal, não era a imortalidade, dentro do espírito agonístico grego, a contrapartida do ideal da morte heroica, a bela morte ${ }^{78}$ Uma vida breve, porém valorosa, não valia muito mais do que uma vida longa sem feitos memoráveis? Aceitar a imortalidade ofertada pela deusa Calipso seria o mesmo que abandonar toda e qualquer possibilidade de se imortalizar entre seus semelhantes, pois a imortalidade, para os gregos, única resposta possível à sua condição de mortal entre mortais, estava implicada no reconhecimento público por parte de seus pares, ${ }^{79}$

\footnotetext{
${ }^{77}$ Passagem semelhante se encontra em A condição humana: “Os homens são 'os mortais', as únicas coisas mortais que existem, porque, ao contrário dos animais, não existem apenas como membros de uma espécie cuja vida imortal é garantida pela procriação" (ARENDT, 2010a, p. 22).

78 “Quando Aquiles explica a Ulisses que preferia 'ser um tete a serviço de um camponês' a reinar sobre o império dos mortos, ele põe em dúvida o ideal da morte heróica, que é precisamente o ideal da Ilíada. A bela morte é o valor exemplar da Ilíada" (VIDAL-NAQUET, 2002, p. 117).

${ }^{79}$ Para Hartog (2004, p. 33-35), na viagem de retorno à Ítaca, Ulisses está fora desse espaço de reconhecimento do outro, fora do espaço dos "homens comedores de pão", os mortais. Para W. Jaeger (2001, p. 31-2), "o homem
} 
isto é, na grandeza fugaz de um ato à vista de todos. Como Arendt (2011, p. 280) anota em seu diário, em dezembro de 1952:

La grandeza como presencia nos destruiría inmediatamente; se da tan sólo como un relámpago, que inmediatamente ha pasado. Cuando se apaga, cuando ha pasado, comienza su "historia", es decir, ahora tiene la posibilidad de la grandeza y la permanencia. Así el pasado es también la dimensión de la permanencia; el presente pasa, el futuro surge, el pasado permanece.

Como Arendt (2010a, p. 61) dirá em A condição humana, a "presença de outros que vêem o que vemos e ouvem o que ouvimos garante-nos a realidade do mundo e de nós mesmos”. Em outras palavras, suas obras, seus feitos e suas palavras - porque perecíveis, “contaminadas com a mortalidade de seus autores" (ARENDT, 1992, p. 72) - eram de tal forma grandes por si mesmos, evidentes por si mesmos, que eram dignos de serem lembrados por seus contemporâneos e imortalizados por poetas e historiadores. Ao serem salvas do esquecimento, tais obras, feitos e palavras

[...] aí estariam em casa, e os próprios mortais encontrariam seu lugar no cosmo, onde todas as coisas são imortais, exceto os homens. A capacidade humana para realizá-lo era a recordação, Mnemósine, considerada portanto como mãe de todas as demais musas (p. 72, grifos nossos).

Estar em casa e encontrar seu lugar no cosmo não é também uma maneira de se reconciliar com o mundo? E não era isso exatamente o que pretendia Ulisses - "me encontrar em minha casa e ver o dia do retorno"? Poderia Arendt, na condição de refugiada e apátrida, como se viu, sentir-se em casa no mundo? Como encontrar seu lugar num mundo do qual foi expulsa? Não seria contando uma história? Origens do totalitarismo pode ser considerado uma narrativa em que Arendt aspira reencontrar um lugar num mundo que a expulsou.

O tema da viagem oferece uma analogia fecunda para se refletir sobre o horror dos campos de concentração nazistas, na medida em que aqueles que partiam para eles embarcavam naquela que seria sua última viagem. Viu-se Arendt dizer a Jaspers que “escrever é uma forma de regressar". É claro que se a metáfora da viagem não implica que toda e qualquer viagem pressuponha retorno, é difícil não admitir que o não retorno signifique

homérico só adquire consciência de seu valor pelo reconhecimento da sociedade a que pertence. Ele é um produto da sua classe e mede a arete própria pelo prestígio que disputa entre os seus semelhantes. [...] De certo modo pode-se dizer que a arete heróica só se aperfeiçoa com a morte física do herói. Ela reside no homem mortal, ou melhor, ela é o próprio homem mortal; mas perpetua-se, mesmo depois da morte, na sua fama, isto é, na imagem da sua arete, tal como acompanhou e dirigiu sua vida". De acordo com Arendt (2010a, p. 59): “A excelência - arete, como a teriam chamado os gregos; virtus, como teriam dito os romanos - sempre foi reservada ao domínio público, em que uma pessoa podia sobressair-se e distinguir-se das demais. Toda atividade realizada em público pode atingir uma excelência jamais igualada na privatividade”. 
fundar, de outro modo, um novo lar no mundo, um lugar em que, de novo, seja possível "me encontrar em minha casa". A publicação de Origens do totalitarismo e a obtenção da cidadania americana em 1951 podem ser figuradas no desejo de Ulisses em retornar. ${ }^{80} \mathrm{O}$ retorno, nesse sentido, é um re-começo. Os judeus e os não judeus que Eichmann embarcava para os campos de concentração seguiam para a morte, uma situação que interditava qualquer possibilidade de iniciar algo por conta própria. De fato, o tema da viagem como retornorecomeço ali está ausente.

A metáfora do retorno de Ulisses é sugestiva para se pensar o rumo, as paradas e, talvez, os desvios da obra de Hannah Arendt. Se ela não sonha com o retorno à maneira do Ulisses odisseico - e o retorno é "doce como o mel” -, parece verossímil que procure um lugar onde possa se sentir "em casa no mundo", ${ }^{81}$ senão fundando uma nova Roma, como o Enéias de Virgílio, ao menos voltando a pertencer a uma comunidade política, porque "a ausência de mundo, infelizmente, é sempre uma forma de barbárie" (ARENDT, 1991, p. 23). Daí o comentário judicioso de Birulés (2009, p. 1, grifo nosso) de que:

Las reflexiones arendtianas en torno a la historia, al pasado, a la memoria y al relato están marcadas por diversos elementos derivados de un claro reconocimiento de la fragilidad y la contingencia de los asuntos humanos. Buena parte de su obra está centrada no sólo en no escapar a ellos sino en pensarlos.

Em contraponto a esse presumível retorno arendtiano, retorno a uma comunidade política, como poderiam os milhões de indivíduos mortos nos campos - morte sem qualquer publicidade, pois longe do domínio público - encontrarem um lugar seu, se lhes foi negado até mesmo o momento de sua retirada do mundo, desse instante de grandeza que, presume-se, seja reconhecido por todos os povos? Amigos e parentes dos que morreram nos campos de concentração não se encontrariam, guardadas as proporções, em condição análoga à de Antígona, na tragédia de Sófocles?

Logo se vê que o empreendimento de Arendt em Origens do totalitarismo, além da grandeza de que se reveste - porque incide sobre a fragilidade e a dignidade humanas e, por extensão, sobre a fragilidade e a dignidade da política -, impõe um grande desafio. Para recuperar o sentido geral de grandeza, daquilo que é grande por si mesmo, e também da ideia de coragem presente no próprio ato de abandonar a esfera privada (lugar protegido do mundo

\footnotetext{
${ }^{80}$ O historiador François Hartog (2004, p. 25) sublinha que a Odisséia é uma "narrativa de viagem inteiramente voltada para o retorno, ansiosa por concluir-se. Narra o retorno daquele que 'durante anos errou... pelo mar, sofrendo muita angústia em sua alma', daquele que, em resposta a uma pergunta do rei Alcínoo, afirma não ser 'senão um mortal', o mais desgraçado talvez".

${ }^{81}$ Ver especialmente o capítulo Em casa no mundo, de Young-Bruhel (1997).
} 
e, portanto, da visibilidade pública - e sua substituição por um espaço de aparência, o espaço público), convém retomar alguns aspectos que aproximam e distinguem a poesia e a historiografia gregas.

\subsection{Poesia e historiografia}

En la acción se pone de manifestó que solo somos vistos por mortales cuya memoria muere con ellos. Ahí radica el origen de la poesía como

memoria eterna.

(ARENDT, 2011, p. 469)

Em Arendt, a exemplo de Aristóteles (Poética), o que a poesia e a historiografia gregas têm em comum é o fato de que ambas visam a salvar do esquecimento a grandeza das ações e dos feitos humanos. A poesia o faz mirando a universalidade dos sentimentos e das ações dos homens: sobre o possível, o que poderia acontecer ou ter acontecido. A História, por sua vez, mirando a particularidade dessas ações: sobre o que realmente aconteceu. E o fazem à medida que perenizam aquilo que não deixaria vestígio senão por meio da recordação. Não é outra a razão de conhecermos os feitos gloriosos de Aquiles imortalizados por Homero. Finley (1989, p. 5) pondera:

Muito antes de alguém sequer sonhar com a história, o mito deu uma resposta. Essa era a sua função, ou melhor, uma de suas funções: tornar o passado inteligível e compreensível selecionando e focalizando algumas partes dele, que, desse modo, adquiriram permanência, relevância e significado universal.

Daí o sentido de Arendt (2010a, p. 242) afirmar que "Aquiles permanece dependente do contador de estórias, do poeta ou historiador, sem os quais tudo o que ele fez teria sido em vão". Aristóteles sublinha na Poética o que há de comum entre o poeta e o historiador, ao realçar, como filósofo, o sentido da tarefa a que ambos se consagram: imortalizar ações, sofrimentos e feitos humanos dignos de glória. E esse é o ponto crucial para Arendt, ainda que passe por alto a diferença entre um aedo que, inspirado pelas Musas, narra uma história como mediador eleito a serviço de uma divindade - e um historiador que, como Heródoto ou Tucídides, funda a validade de seu relato numa pesquisa (historien), ${ }^{82}$ instituindo um saber que se apreende em parte por oposição à tradição poética, ainda que esteja a ela referido.

\footnotetext{
${ }^{82}$ Tucídides evita o termo historien empregado por Heródoto.
} 
Para os propósitos deste trabalho, convém reter esse elo original entre poesia e historiografia gregas, ainda que ele seja controverso ${ }^{83}$ - por iluminar, ao final, o sentido formativo da História no âmbito da educação, mas também apontar o que as distingue. Arendt (1992, p. 74-5) assim sublinha o elo original entre a epopeia e a historiografia grega:

A História como uma categoria de existência humana é, obviamente, mais antiga que a palavra escrita, mais antiga que Heródoto, mais antiga mesmo que Homero. Não historicamente falando, mas poeticamente, seu início encontra-se, antes, no momento em que Ulisses, na corte do rei dos Feácios, escutou a estória de sua vida, agora algo fora dele próprio, um "objeto" para todos verem e ouvirem. O que fora pura ocorrência tornou-se agora "História". [...] A cena [...] é paradigmática tanto para a História como para a poesia; a "reconciliação com a realidade", a catarse, que segundo Aristóteles era a própria essência da tragédia, constituía o objetivo último da História, alcançado através das lágrimas da recordação.

História e poesia se enredam ao proporcionar uma "reconciliação com a realidade" quando o tempo está "fora dos eixos", talvez para desespero daqueles que se veem na tarefa de pô-lo em ordem. Essa passagem da Odisséia (canto VIII), bem como a imagem que Arendt dela evoca sobre a necessidade de o homem buscar reconciliar-se com o mundo, é altamente sugestiva de como a própria obra da autora é testemunho dessa busca de reconciliação. Os tempos sombrios, na expressão que toma de Brecht, não são outro modo de dizer que o mundo está “fora dos eixos"? E a narrativa histórica e a poesia não comparecem aí como linguagens possíveis - não as únicas, certamente - da capacidade humana de compreender o mundo, reconciliar-se com ele e, por fim, atribuir-lhe sentido? Pois compreender, para Arendt (1993a, p. 39, grifo nosso), é

[...] a maneira especificamente humana de estar vivo, porque toda pessoa necessita reconciliar-se com um mundo em que nasceu como um estranho e no qual permanecerá sempre um estranho, em sua inconfundível singularidade. A compreensão começa com o nascimento e termina com a morte.

\footnotetext{
${ }^{83}$ Dois exemplos contrastantes iluminam a questão. O historiador Moses Finley levanta alguns senões sobre o nono capítulo da Poética, de Aristóteles, fonte de Arendt para aproximar poesia e historiografia, conforme a nota 6, p. 74, de $O$ conceito de história: antigo e moderno. Segundo Finley $(1989$, p. 4): "Não é de admirar que, dentre todos os capítulos, o nono talvez seja a maior vítima da conhecida 'reclamação contra as supostas omissões de Aristóteles na Poética'. [...] Aristóteles nunca se ocupou da história, nem no capítulo nove nem em qualquer outro. Afora duas referências casuais na Poética [...], ele não torna a mencionar esse assunto [a história] em nenhum ponto da vasta obra a nós transmitida. Nada poderia ser mais significativo do que esse profundo silêncio". W. Jaeger (2001, p. 63), porém, endossa a posição de Aristóteles acerca da superioridade da poesia em relação à história, indo mais além: "a poesia tem vantagem sobre qualquer ensino intelectual e verdade racional, assim como as meras experiências acidentais da vida do indivíduo. É mais filosófica que a vida do indivíduo (se nos é lícito ampliar o sentido de uma conhecida frase de Aristóteles), mas é, ao mesmo tempo, pela concentração de sua realidade espiritual, mais vital que o conhecimento filosófico".
} 
A reconciliação, portanto, é intrínseca à compreensão, e esta, por sua vez, a contraparte da ação. Necessitamos compreender, e a História é uma das formas de exercer a faculdade da compreensão, porque, para Arendt, quando o mundo se desarranja - e por vezes expulsa e priva os homens da ação e do discurso -, somos convidados a entrar num acordo com ele, voltar a sentir que o mundo ainda pode ser um lar para vivermos. Essa reconciliação alcançada pela compreensão não significa, como se viu no prefácio de Origens do totalitarismo, "negar nos fatos o chocante" ou "eliminar deles o inaudito", mas "encarar a realidade sem preconceitos e com atenção, e resistir a ela - qualquer que seja" (ARENDT, 1989, p. 12). Nesse sentido, pode-se desdobrar um pouco a cena em que Ulisses, na corte dos feácios, ouve a história de seus próprios feitos do aedo Demódoco e de como compreende sua errância, reconcilia-se com a realidade e, assim, o mundo volta a estar prenhe de sentido. Ali, a linguagem metafórica da poesia cantada por Demódoco lança uma ponte (ARENDT, 1999, p. 118) entre dois mundos: de um lado, o invisível do pensamento, da imaginação, da lembrança; de outro, a dura realidade de seu sempre adiado retorno a Ítaca.

Arendt capta o inusitado da cena, "visto que ouvinte, ator e sofredor são a mesma pessoa". Mas o que tem em mira ao constatar essa sobreposição - o que fora pura ocorrência tornou-se agora "História" - é ilustrar que Ulisses pode suportar seus infortúnios porque eles se tornaram uma narrativa. Ocorre que essa sobreposição entre ator, ouvinte e sofredor, isto é, entre ator e espectador, produz certo curto-circuito na própria narrativa da Odisséia, uma espécie de anomalia, na sugestão de Hartog (1999, p. 14): “Assistimos, com efeito, à primeira narração do acontecimento. Com esta singularidade: a presença de Ulisses lá [na Ilíada] e aqui [na Odisséia] permite atestar que 'isso' realmente ocorreu”. Voltemos aos feácios, ao próprio Ulisses e a modo como se dirige ao aedo:

Demódoco, louvo-te acima de todos os mortais: / ou a Musa, filha de Zeus, ou Apolo te ensinou, / pois bem ordenado cantas o infortúnio dos aqueus, / quanto realizaram, o que sofreram e quanto suportaram os aqueus / como se tivesses presenciado, ou de um outro o ouvisses. / Mas vamos, muda e conta a trama do cavalo / de pau, que Epeio construiu com Atena, / e que então o divino Odisseu, doloso, levou para a fortaleza, / preenchendo-o de guerreiros que Ilíon saquearam (apud PIRES, 1999, p. 241).

O louvor que Odisseu/Ulisses presta a Demódoco - "louvo-te acima de todos os mortais" - deve-se à excelência do canto do aedo, ao fato de salvar do olvido as ações daqueles que se mostraram dignos de memória. Ora, mas já se viu que a poesia e a historiografia são dois modos de responder à inerente fragilidade das ações humanas. De homens que se sabem mortais, como Ulisses, mas cuja grandeza de atos e palavras - porque 
medidas contra um pano de fundo de coisas imortais - está sempre na dependência de poetas e contadores de histórias; do contrário, atos e palavras se desvanecem no tempo. Como pode, então, esse Ulisses vivo ocupar, ainda que brevemente, o lugar de um Ulisses morto?

Ulisses encontra-se na penosa posição de ter de ouvir a narração de seus feitos, na terceira pessoa: como se estivesse ausente, como se estivesse morto. [...] A epopéia, e a história depois dela e como ela, pressupõe a morte, ou antes a tecem com suas palavras. Como uma mortalha que, recobrindo o rosto dos mortos, deles faz justamente mortos. No momento mesmo que Ulisses acredita finalmente retomar seu passado glorioso, passa, em meio aos Feácios e por meio das palavras mesmas de Demódoco, pela experiência da morte. Está morto, está vivo? Ele ouve o que um vivo, normalmente, não poderia ouvir (HARTOG, 1999, p. 16).

Mas ouviu. E talvez seja essa experiência um tanto anômala no interior da narrativa da Odisséia que faz com que Ulisses - um ouvinte atípico - elogie Demódoco de uma forma que um ouvinte-espectador comum não faria: "Como se tivesses presenciado, ou de um outro ouvisses". Demódoco nem presenciou, nem ouviu - ademais, era cego. A privação da visão física é a contraparte do dom narrativo que a divindade lhe concedeu de ver os dois lados da contenda: "A quem, dentre todos, a Musa amou, e deu-lhe [a Demódoco] bem e mal: / dos olhos privou-o, mas concedeu-lhe agradável canto" (apud PIRES, 1999, p. 242). Daí porque a veracidade do relato de qualquer aedo se funda no fato de que, a despeito de ser um mortal como outro qualquer, ele recebe o dom divino de narrar os feitos memoráveis por meio de seu canto. Pires (1999, p. 207) assim resume tal empresa:

Súbita, a voz do aedo rompe o silêncio, e irrompe em palavras e música um canto destinado a celebrar as obras dos deuses e os feitos heróicos dos homens de outrora. Assim, disposto a atualizar uma dessas histórias na ambiência humana de uma dada comunidade de ouvintes, o bardo logo ativa o contato com o ente divino de quem provém seu conhecimento: um rogo, 'pura prece' de apelo direto e autônomo graças a um excepcional relacionamento íntimo com a divindade, é dirigido à(s) Deusa(s), nomeada(s) Musa(s), filha(s) de Zeus e Mnemosine (Memória).

O conteúdo da narrativa, portanto, não é o que o aedo testemunha por conta própria, nem por ouvir dizer - como se dá em Heródoto e Tucídides -, mas aquilo que "ou a Musa, filha de Zeus, ou Apolo" lhe ensinaram. Ulisses, porém, é tentado a crer que Demódoco testemunhou de fato o que canta, quando na verdade a única testemunha ali presente é o próprio Ulisses, que além de espectador foi ator da história narrada. Nessa amálgama produtora da catarse, ele chora: 
De fato, para a Musa, ver, saber e dizer caminham paralelamente. O wie es eigentlich gewesen ${ }^{84}$ lhe é habitual! Assim o pressupõe o dispositivo da palavra épica. Mas, para Ulisses, por uma curiosa reviravolta, é a visão humana que é promovida, pelo menos por ocasião destes três versos, a padrão pelo qual se mede a justeza da visão divina (HARTOG, 1999, p. 15).

A reviravolta se dá justamente pela promoção da visão humana - espécie de desvio como critério de validação da visão divina, uma valoração que antecipa poeticamente uma visão historiadora ainda por se constituir em Heródoto (e para a qual a epopeia ainda não dispõe de um nome) e que toma como critério da verdade a visão, o testemunho direto e, na impossibilidade deste, a audição/inquirição de outros que testemunharam os fatos.

Para os propósitos deste trabalho, apesar da importância de se discutir a origem da figura do historiador, bem como a História enquanto um saber distinto - questão para a qual Hartog dá decisiva contribuição -, o importante foi recuperar o elo comum entre poesia e historiografia. Sem negar essa correlação, o fato é que Hartog não compartilha da leitura que Arendt faz da cena de Ulisses em meio aos feácios. O brilhantismo de seu artigo parece perder de vista o ponto alto do insight arendtiano, que é justamente assinalar não apenas a correlação entre poesia e História, mas o fato de que ambas parecem desde a origem implicadas, em algum grau e de alguma forma, com o fato de que toda ação deixa - ao menos potencialmente - uma história atrás. Essa história, quando recuperada e reificada numa narrativa, possibilita o exercício da compreensão e da reconciliação com o mundo, e esse é o aspecto que particularmente interessa aqui.

Arendt está menos interessada num relato historiográfico estrito. Sua perspectiva é híbrida, fronteiriça, escorregadia. Um ponto qualquer entre a universalidade da literatura e da poesia e a particularidade da História com vistas a recuperar a dignidade da política. No fundo, Arendt está contando a história de um esquecimento: o esquecimento do político ou da degradação da ação na era moderna, em razão de uma inversão na hierarquia das atividades da vida ativa. Na polifonia que apresenta da ação - ela opta pela expressão suíte política -, esta representava o ponto mais alto das atividades da vita activa para os antigos. Em Marx, como se verá no próximo capítulo, o trabalho é alçado ao ponto mais alto e a ação é tomada à imagem da obra/fabricação.

Esse lugar fronteiriço da análise histórica arendtiana ajuda a compreender o fato de que dezenas de obras literárias invadam seus ensaios ou exercícios de pensamento, como ela costumava dizer. Tais fragmentos literários e poéticos misturam-se às tramas de suas análises histórico-políticas, são arrancados de seu contexto para se tornarem capazes de iluminar a

\footnotetext{
84 “Como as coisas foram realmente".
} 
realidade que ela quer compreender e narrar. Não há dúvida de que um olhar que se coloca nessa região fronteiriça resulta problemático quando se interpreta a obra arendtiana no âmbito estrito da comunidade de historiadores. As licenças que ela se permite incomodam o cânone historiográfico. No entanto, ela não desconhece o procedimento tido como canônico por aquela comunidade. Ao contrário, é justamente por conhecer a fundo tais procedimentos que Arendt os afronta, por perceber que a linguagem consagrada das Ciências Sociais e da História já não é capaz de traduzir o fenômeno que pretende compreender. Ela funda novos procedimentos analíticos, ainda que em caráter experimental.

Tais experimentos podem se mostrar extremamente fecundos quando o que estiver em jogo for menos avaliar a pertinência e a validade da obra de Arendt em conformidade com o cânone historiográfico, e mais o quanto alguns desses procedimentos nos convidam a refletir sobre o status atual da narrativa, não no âmbito da História - o que não se fará aqui -, mas no âmbito do ensino de História.

Não é à toa a empatia de Arendt por uma frase da escritora dinamarquesa Isak Dinesen, utilizada como epígrafe de seu capítulo sobre a ação em A condição humana: "Todas as mágoas são suportáveis se as colocamos em uma estória [story] ou contamos uma estória sobre elas" (apud ARENDT, 2010a, p. 219) ${ }^{85}$ Em traços largos, o sentido político da frase de Dinesen remete ao que se viu no canto VIII da Odisséia, quando Ulisses chora ao ouvir a história dos próprios feitos cantada pelo aedo Demódoco. O problema é que se toda ação deixa uma história para ser narrada, não há nenhuma garantia de que isso aconteça. Justamente por não deixar um produto atrás de si, mas apenas a possibilidade de uma história, Arendt (2010a, p. 246) sublinha:

Homero não foi somente um brilhante exemplo da função política do poeta e, portanto, o "educador de toda Hélade"; o próprio fato de que um empreendimento tão grandioso como a guerra de Tróia pudesse ter sido esquecido sem um poeta que o imortalizasse centenas de anos depois exemplifica muito bem o que poderia ocorrer com a grandeza humana, se esta tivesse de se fiar apenas nos poetas para garantir sua permanência.

O que Arendt parece assinalar é que escrever e contar histórias é tanto uma forma de remediar a fragilidade que acompanha toda ação, isto é, o risco de se desvanecer completamente, quanto um modo de permitir uma reconciliação com o mundo. Tanto a epígrafe de Dinesen quanto o fragmento sobre Homero remetem ao fato de que, quando os homens agem, independentemente dos motivos, princípios e objetivos que os movem, eles se

85 A frase também se encontra em Homens em tempos sombrios: “Todas as dores são suportáveis se as incluirmos numa história ou contarmos uma história acerca delas” (ARENDT, 1991, p. 125). 
encontram na dependência dos espectadores, poetas e historiadores - sem os quais não seria possível salvar o quem por trás da ação. Essa percepção da ação se amplia quando a vemos sob o pano de fundo de outra atividade da vida ativa, como a obra. Desprovida de um nome, de um quem a ela associado, a ação perde todo o sentido, ao passo que uma obra de arte conserva sua relevância, quer saibamos ou não o nome do artista. Em outras palavras, a ação não deixa produtos tangíveis que lhe possam conferir permanência, ao contrário dos produtos resultantes da atividade da fabricação, tal como uma obra de arte, exemplo máximo de permanência para Arendt (2010a, p. 209): "Dada sua excepcional permanência, as obras de arte são as mais intensamente mundanas de todas as coisas tangíveis". Esse exemplo é especialmente esclarecedor da distinção arentdiana entre obra e ação, e não é gratuito o fato de ela comparar a ação às artes de desempenho (performing arts), como a dança, o teatro ou a música, opondo-as, por sua vez, às artes criativas, como a escultura, a pintura, a poesia:

As artes de desempenho [performing arts] [...] têm como efeito uma grande afinidade com a política. Os artistas executantes - dançarinos, atores, músicos e o que o valha - precisam de uma audiência para mostrarem seu virtuosismo, do mesmo modo como os homens que agem necessitam da presença de outros ante os quais possam aparecer, ambos requerem um espaço publicamente organizado para sua "obra", e ambos dependem de outros para o desempenho de si (ARENDT, 1992, p. 200, tradução modificada).

A ação, portanto, é um desempenho efêmero, uma performance que não deixa resultado tangível. A performance ou desempenho é a própria obra ou, nas palavras de Arendt (2010a, p. 257), “a obra não sucede ao processo e o extingue”. Nesse sentido, ela só pode ser remediada em sua fragilidade quando observada por aqueles que não agem, mas testemunham a ação: os espectadores. Estes, quando a ação termina, se assim o desejarem, podem contar uma história, aquela história que se deixou revelar pelos que agiram em conjunto. Ocorre que, para que uma história se revele, ela precisa de uma audiência, de um palco, de um espaço de aparência: "aquilo que é visto e ouvido pelos outros e por nós mesmos constitui a realidade (ARENDT, 2010a, p. 61).

Uma segunda epígrafe com que Arendt abre o capítulo sobre a ação em $A$ condição humana é de Dante e remete justamente ao prazer daquele que age, uma vez que a ação intensifica a existência do agente, revelando-o. ${ }^{86}$ Esse caráter intensificador da ação é

\footnotetext{
${ }^{86}$ Eis a epígrafe de Dante: "Pois em toda ação o que é visado primeiramente pelo agente, quer ele aja por necessidade natural ou por livre arbítrio, é revelar sua própria imagem. Daí resulta que todo agente, na medida em que age, sente prazer em agir; como tudo o que é, deseja sua própria existência, e como na ação a existência
} 
emblemático quando visto sob o pano de fundo da natalidade, pois, para Arendt (2010a, p. 221):

É com palavras e atos que nos inserimos no mundo humano, e essa inserção é como um segundo nascimento, no qual confirmamos e assumimos o fato simples do nosso aparecimento físico original. Não nos é imposta pela necessidade, como o trabalho, nem desencadeada pela utilidade, como a obra. $^{87}$

Justamente por não ser "imposta pela necessidade, como o trabalho", tampouco “desencadeada pela utilidade, como a obra”, a ação é a única atividade realmente livre entre as três atividades da vida ativa consagradas ao exame em A condição humana. O aspecto contingente de toda ação, isto é, o fato de ela se inserir numa teia de relações entre homens plurais, faz com que o preço da liberdade seja a impossibilidade de garantir o resultado da ação, ou seja, sua imprevisibilidade. Tanto a Ilíada quanto a Odisséia, bem como a historiografia antiga, são pródigas de exemplos sobre o caráter imprevisível das ações humanas, cujas consequências não confirmam as intenções do agente, mas, quando muito, forçam as coisas em determinada direção. Talvez a única exceção seja Aquiles,

[...] porque se retira, na morte, das possíveis consequências e da continuação do que iniciou. $O$ que dá à história de Aquiles sua significância paradigmática é o fato de que ela mostra, laconicamente, que o preço da eudaimonia ${ }^{88}$ é a própria vida e que uma pessoa só pode estar segura dela quando renuncia à continuidade da existência ao longo da qual nos revelamos aos poucos, quando resume toda a existência num único feito, de sorte que a estória do ato termina ao mesmo tempo em que a vida (ARENDT, 2010a, p. 242).

Quando o filho de Ulisses, Telêmaco, solicita aos arautos de Ítaca a convocação de uma assembleia para deliberar sobre o problema do assédio dos pretendentes de sua mãe, Penélope, e do espoliamento de seus bens por parte dos pretendentes, tinha claras intenções de persuadir a assembleia de que as razões de sua desgraça seriam compreendidas e de que os males que o afligiam seriam, enfim, contornados. Mas o que se seguiu ao seu discurso em

do agente é de certo modo intensificada, resulta necessariamente o prazer [...]. Assim, nada age, a menos que [ao agir] torne patente seu si-mesmo latente" (ARENDT, 2010a, p. 219).

${ }^{87}$ Almeida observa que, na versão alemã de $A$ condição humana, (revista e ampliada por Arendt), ela ressalta, nesse mesmo trecho, a responsabilidade que se assume pelo mundo ao agir. Segue a tradução do alemão que ela propõe: "Falando e agindo intervimos no mundo dos homens, o qual existia antes de termos nascido nele; e esta intervenção é como um segundo nascimento, no qual confirmamos o mero fato de termos nascido, assumindo a responsabilidade por ele" (Cf. ALMEIDA, 2011, p. 129).

${ }^{88}$ Arendt (2010a, p. 241) assim define eudaimonia: "Porque eudaimonia não significa felicidade nem beatitude; é intraduzível e talvez até inexplicável. Tem a conotação de bem-aventurança, mas sem qualquer implicação religiosa, e significa, literalmente, algo como o bem-estar do daimon que acompanha cada homem durante toda a sua vida, que é a sua identidade distinta, mas só aparece e é visível para os outros”. 
nada acompanhou as intenções que o sustentavam. Ao contrário, Antino tomou a palavra na assembleia de Ítaca e replicou Telêmaco, isentando os pretendentes de qualquer culpa e jogando sobre Penélope as razões da desgraça. Sustentou que ela ludibriava os pretendentes com esperanças vãs, com a promessa de que tão logo a mortalha de Laerte, pai de Ulisses, ficasse pronta, consentiria em casar-se com o pretendente de seu agrado. Por fim, disse que os pretendentes continuariam a consumir os bens de Telêmaco enquanto a astuciosa Penélope não escolhesse um novo marido. A telemaquia, composta pelos quatro primeiros cantos da Odisséia, narra justamente esse segundo nascimento de Telêmaco, tímido jovem de 20 anos agora disposto a se tornar um homem corajoso e, quem sabe, astucioso como o pai. Não deixa de ser admirável o fato de que Telêmaco figure como único personagem jovem da epopeia em que se flagra a passagem para a vida adulta. "Já não deves viver como criança - diz Atena a Telêmaco -, tens idade demais para isso" (JAEGER, 2001, p. 58). O fato de que seu primeiro ato adulto termine num malogro parece deixar evidente o caráter pedagógico da telemaquia.

\subsection{A ação entre a guerra homérica e a polis pré-platônica}

Entre o malogro do discurso de Telêmaco diante da assembleia de Ítaca e os discursos de Péricles ante os atenienses por ocasião da Guerra do Peloponeso, o que une, na perspectiva de Arendt, esses dois universos em face da ação e do discurso? Em outras palavras, o que a invenção da polis representa senão a evidente inversão da máxima de Clausevitz, de que "a guerra é a continuação da política por outros meios”? Vernant (1972, p. 42-3) observa que

[...] a guerra representa o estado normal na relação entre cidades. Tal presença, entretanto, natural e necessária, reveste também a forma de uma ausência, uma vez que a guerra não constitui mais, na vida social, um domínio à parte, com suas instituições e seus agentes especializados, seus valores, sua ideologia, sua religião própria, e sim confunde-se com a vida comum do grupo tal como se exprime nas estruturas do Estado. A guerra não é apenas submetida à cidade, ao serviço da política; ela é a própria política; e se identifica com a cidade porque o agente guerreiro coincide com o cidadão, manifesta-se como guerreiro ao mesmo tempo que é um agente político tendo poder de regular, com o mesmo direito, os negócios comuns do grupo.

Para Arendt, a polis não consistia em suas leis - como pensavam os romanos a partir do ato de fundação -, tampouco no espaço físico dos muros que a conformavam. Legisladores e arquitetos exerciam uma atividade de produção nos moldes da fabricação (poiésis), cuja natureza é pré-política, e não política como a ação (práxis). Suas atividades, portanto, 
diferentemente das ações, sempre imprevisíveis, tinham um modelo e um fim prédeterminado:

Antes que os homens começassem a agir, era necessário assegurar um lugar definido e nele erguer uma estrutura dentro da qual pudessem ocorrer todas as ações subseqüentes; o espaço era o domínio público da polis e a estrutura era a sua lei; legislador e arquiteto pertenciam à mesma categoria (ARENDT, 2010a, p. 243).

Vista desse ângulo, a polis é um espaço de aparência onde não mais um guerreiro corre os riscos inerentes à ação, revelando sua excelência (arete) ante seus pares e aspirando com isso a imortalizar-se, mas onde um cidadão (que em certas circunstâncias torna-se um cidadão em armas) busca notabilizar-se no espaço público-político por meio da ação (práxis) e da palavra (lexis) para persuadir um público de cidadãos. Esse espírito agonístico - "o apaixonado impulso de alguém para exibir seu si-mesmo ao medir-se com os outros" (ARENDT, 2010a, p. 243) - confere à ação um caráter altamente individualista e marca profundamente o conceito de política nas cidades-Estado gregas. ${ }^{89}$ Assim, o ponto de contato entre o campo de batalha e a polis é que ambos conformam um espaço comum de aparência, espaço constituído entre os combatentes e os cidadãos, onde todos podem ver e ser vistos, atuar e proferir palavras:

[...] la acción solo es política cundo va acompañada de la palabra (lexis), en la medida en que esta última convierte en significativa la práxis. Y en este sentido, la palabra es entendida como una suerte de acción, como una vía para conferir sentido y durabilidad al mundo y para decir nuestra responsabilidad con respecto a él. ${ }^{90}$

Uma frase do velho Fênix, o educador de Aquiles, oferece um exemplo significativo da relação entre guerra e política. Num momento decisivo da batalha, ele recorda ao jovem guerreiro as razões de sua educação: "proferir palavras e realizar ações" (apud JAEGER, 2001, p. 30). Diferentemente do campo de batalha, entretanto, a polis - que "não era Atenas, e sim os atenienses" (SCHACHERMEYR apud ARENDT, 2010a, p. 243) - aparece "metafórica e teoricamente (e não historicamente, é claro)" como um substituto duradouro daquelas circunstâncias esporádicas da guerra, onde "as chances de um feito merecedor de fama ser lembrado", isto é, "de que realmente se tornasse 'imortal', não eram muito boas"

\footnotetext{
${ }^{89}$ Acerca desse espírito agonístico, "o apaixonado impulso de alguém para exibir seu si-mesmo ao medir-se com os outros" convém lembrar, a despeito de algumas interpretações em contrário, que Arendt jamais pretendeu fazer a apologia do mesmo. Para ela, ele representou a um só tempo o "incrível desenvolvimento do talento e do gênio em Atenas, bem como do rápido e não menos surpreendente declínio da cidade-Estado" (Cf. ARENDT, 2010a, p. 243, 246).

${ }^{90}$ Cf. BIRULÉS, 1997: 27.
} 
(ARENDT, 2010a, p. 246). Enquanto na guerra o reconhecimento da excelência do guerreiro se encontra na dependência do poeta e do historiador, a polis ergue-se, ela própria, como espaço permanente de memória, uma espécie de memória organizada de seus cidadãos, um âmbito público que surge entre os homens, menos, portanto, como obra de suas mãos e mais como uma virtualidade, que pode ou não surgir, dependendo de que os homens se reúnam em palavras e atos, em condição de igualdade e dispostos a constituir um mundo comum por meio de acordos e promessas. Correia (2010a, p. XXXI) sublinha que

Em um sentido bem fundamental, a razão de ser da política, para Arendt, é a redenção da mortalidade e da futilidade da existência humana mediante a edificação de um espaço durável para a liberdade, no qual a grandeza frágil e fugaz das palavras e feitos dos mortais se manifesta e encontra abrigo e louvor.

Arendt (2010a, p. 247-8) recorda que a polis, segundo a Oração fúnebre de Péricles que consta em Tucídides,

[...] fornecia uma garantia para os que haviam obrigado mares e terras a tornar-se o cenário da sua audácia de que não ficariam sem testemunho e não dependeriam do louvor de Homero nem de qualquer outro artista da palavra; [...] metafórica e teoricamente [...] é como se os que regressaram da guerra de Tróia desejassem tornar permanente o espaço da ação que havia surgido de seus feitos e sofrimentos, e impedir que esse espaço desaparecesse com a dispersão deles e o regresso de cada um a seus domicílios isolados.

Ora, e que nome se pode dar a esse "espaço de ação" permanente? Voltar à dimensão privada da vida significava, na perspectiva dos gregos, que se devia renunciar à liberdade, pois o espaço doméstico é o espaço da necessidade e, diante dela, ninguém pode ser livre. Esse aspecto público da liberdade no agir está longe de ser algo autoevidente a um olhar hodierno, acostumado a associar liberdade ao âmbito da privacidade ou mesmo a uma condição de se ver literalmente livre ante os assuntos público-políticos. Em resumo, o que aqui se pretendeu ressaltar é que tanto a poesia, quanto a história e a polis aparecem para Arendt como a resposta ao paradoxo grego da mortalidade. O exame contrastado da tríade natalidade-ação-imortalidade entre antigos e modernos, à maneira de uma polifonia em que passado e futuro dialogam, é que permitirá a Arendt complementar sua crítica à moderna concepção de história. 


\section{A história como um processo feito pelo homem}

Desde os tempos de Homero, às grandes guerras sucedem grandes narrativas, e grandes narradores saem se arrastando das ruínas de cidades destruídas e paisagens devastadas. [...] Palavra por palavra, os relatos chegam em casa por telefone ou telégrafo, e por vezes, enterrados sob uma avalanche de notícias, emergem como diamantes preciosos faiscando num monte de pedras sem valor.

(ARENDT, 2008b, p. 113)

Marx, ao saltar da Filosofia para a Política, transportou as teorias da dialética para a ação, tornando a ação política mais teórica e mais dependente que nunca daquilo que hoje chamaríamos uma ideologia. [...] ele superpôs a "lei da História" à Política, findando por perder o significado de ambas - da ação não menos do que do pensamento, e

da Política não menos que da Filosofia - ao insistir em que eram meras funções da sociedade e da história.

(ARENDT, 1992, p. 57)

A solução grega para o problema da mortalidade dos homens num mundo imortal deuse por meio da faculdade humana de recordar. Poetas e historiadores conferem imortalidade a palavras, feitos e sofrimentos humanos, a fim de que permaneçam além do breve tempo de sua duração. A noção de grandeza inerente aos eventos - aquilo "que devia ser admitido na companhia das coisas que perduraram para sempre” (ARENDT, 1992, p. 77) - foi aqui lembrada como importante componente do conceito antigo de história. Evidenciou-se, assim, o destacado lugar que Arendt atribui à poesia e à narrativa historiográfica em suas reflexões sobre a ação humana. Uma e outra conferem dignidade à política. Mas essa dignidade, para Arendt (1992, p. 89, grifo nosso), não sobrevive na era moderna:

$\mathrm{Na}$ época moderna a História emergiu como algo que jamais fora antes. Ela não mais compôs-se dos feitos e sofrimentos dos homens, e não contou mais a história dos eventos que afetaram a vida dos homens; tornou-se um processo feito pelo homem, o único processo global cuja existência se deveu exclusivamente à raça humana.

A mudança operada no conceito de história obviamente não se fez de um salto, mas por um longo caminho. Arendt seleciona momentos marcantes dessa mudança, dos quais três importam em especial, na medida em que pavimentam o terreno para que a história se torne, afinal, "um processo feito pelo homem".

A recuperação de tais momentos tem o propósito de compreender como a ação (práxis), uma performance que revela o agente e não deixa atrás de si um produto tangível 
como a fabricação (poiésis), passa a ser concebida, na era moderna, à imagem da fabricação. Ao se transportar a lógica que preside o homo faber para o campo das relações políticas, a ação foi reduzida e transfigurada em fabricação, pois passou a ser concebida como aquisição de meios para a obtenção de fins. Essa mudança afetou o âmbito da História e, especialmente, as modernas filosofias da História, que desviaram seus interesses do presente para o futuro, dos eventos - e de sua particularidade iluminadora - para os processos históricos. Isso não significa que a noção de processo fosse estranha aos antigos, ou que a particularidade de um evento não guardasse relação com o todo. Ocorre que o evento em si era revelador, "não necessitando de um processo envolvente e engolfante para se tornar significativo" (ARENDT, 1992, p. 96). No âmbito da ação, que é o escopo de Arendt, tais mudanças implicaram um deslocamento do interesse da política para a história, bem como do passado e do presente para o futuro.

Por fim, cabe notar outra distinção fundamental entre fabricação e ação. A fabricação pressupõe violência - a retirada da matéria do ciclo recorrente da natureza e sua posterior transformação - e tem como finalidade acrescentar um produto tangível (um artifício humano) ao repertório do mundo. Diferentemente, a ação pressupõe interação entre uma pluralidade de homens que agem em meio a uma teia de relações. Por ser uma interação entre agentes, seus resultados são sempre da ordem do imprevisível. Não há, pois, em sentido estrito, uma "obra" que resulte da ação. Antes, seu "produto" é a própria performance e o que ela revela é o sentido da ação aos olhos do espectador.

\subsection{Dando as costas à imortalidade}

A primeira transformação que Arendt destaca no moderno conceito de história está ligada à solução encontrada para o paradoxo da mortalidade no âmbito da filosofia. Para ela, a tradição da filosofia política remonta a Platão, que, ao dar as costas aos negócios humanos (à vida ativa), procurou abrigar-se na segurança da vida contemplativa e, posteriormente, impor à polis os padrões do bios theoretikos. Solução diversa, portanto, daquela dada pelos primeiros historiadores, uma vez que não se fez à custa da ação, da performance dos agentes políticos. Muito pelo contrário. Na $14^{\mathrm{a}}$ seção do volume Pensar, de $A$ vida do espírito, que leva o sugestivo título de Os pressupostos pré-filosóficos da filosofia, Arendt conta a história de um poema perdido de Píndaro que descreve uma festa de casamento de Zeus. A certa altura da festa, Zeus pergunta aos demais deuses se ainda lhes faltava algo para que fossem bem- 
aventurados. Eles então the suplicam que crie "alguns novos seres divinos que soubessem como embelezar todas as suas grandes obras "com palavras e música"” (ARENDT, 1999, p. 150). Ora, os seres divinos que Píndaro tinha em mente eram os poetas e os bardos, pois "a narrativa sobrevive ao ato" e "uma coisa dita caminha na imortalidade se tiver sido bem dita". Os bardos, como Homero, "corrigiam a narrativa [...] em [...] palavras mágicas para depois encantarem todos os homens" (PÍNDARO apud ARENDT, 1999, p. 150).

Assim, a "História acolhe em sua memória aqueles mortais que, através de feitos e palavras, se provaram dignos da natureza, e [...], em que pese sua mortalidade, podem permanecer na companhia das coisas que duram para sempre (ARENDT, 1992, p. 78). Diferentemente, num arco que sai de Parmênides e chega ao clímax em Platão, os filósofos descobriram que o pensamento era um "lugar" muito mais seguro para abrigar a imortalidade do que o espaço público que nasce em meio à pluralidade dos homens por meio de palavras, feitos, sofrimentos e ações: "O desejo platônico de substituir a ação pela fabricação, visando a conferir aos assuntos humanos a solidez inerente à obra e à fabricação, torna-se mais evidente quando atinge o próprio cerne de sua filosofia, a doutrina das idéias" (ARENDT, 2010a, p. 281). Até a República, a ideia ou imagem (eidos) mais elevada para Platão eram variações da ideia do belo, "aquilo que mais brilha (ekphanestaton)". Já na República, segundo a interpretação de Arendt, Platão opera uma transformação. Em vez do belo, a ideia mais elevada passa a ser uma série de derivações da ideia do bem - na acepção grega - do bom para ou do que é adequado:

Essa transformação foi necessária a fim de aplicar a doutrina das idéias à política, e foi para um fim essencialmente político - eliminar dos assuntos humanos seu caráter de fragilidade - que Platão julgou necessário declarar que o bem, e não o belo, é a idéia mais elevada [...] para o rei-filósofo, que deseja governar os assuntos humanos porque tem de passar a sua vida entre os homens e não pode habitar para sempre sob o céu das idéias (ARENDT, 2010a, p. 281-2, grifo nosso).

A conclusão de Arendt é de que o projeto da filosofia política platônica, por um lado, aspirava a abolir a esfera pública, enquanto espaço de aparência que surge entre os homens e que possibilita o surgimento de uma pluralidade de visões sobre aquilo que é comum (koinon), e, por outro, negava ao homem a possibilidade de medir e comparar a grandeza de seus feitos e de si próprio, ante a imortalidade dos deuses e da natureza. Ao não optar pela imortalidade, mas por um substituto desta - a experiência do eterno (o pensamento puro que culmina na contemplação da verdade) -, Platão negava a dignidade de um modo de vida, o bios politikos, que é o modo de vida dos cidadãos da polis. Em seu lugar, ele dignificava o 
bios theoretikos, o modo de vida do filósofo, que "só pode ocorrer fora dos assuntos humanos e fora da pluralidade dos homens" (ARENDT, 2010a, p. 24).

A segunda mudança a pavimentar o terreno para que a história emergisse como "um processo feito pelo homem" liga-se ao advento da filosofia cristã, notadamente pela interpretação agostiniana da história e de como ela implicou uma reavaliação do conceito e da relação que a Antiguidade greco-latina estabelecia entre vida e mundo. Para Arendt (2010a, p. 392-3), o senso de grandeza que para os gregos era algo evidente e para os romanos consubstanciava-se no ato inaugural da fundação ${ }^{91}$ não ficaria intacto na era cristã, pois "a 'boa nova' cristã da imortalidade da vida humana individual invertera a antiga relação entre o homem e o mundo, promovendo aquilo que era mais mortal, a vida humana, à posição de imortalidade ocupada até então pelo cosmo". Em outras palavras, o cristianismo conferiu à vida do indivíduo uma sacralidade até então ignorada. Ora, tanto Heródoto como Tucídides justificam suas narrativas das guerras contra os persas e os peloponésios lembrando que os fatos narrados eram grandes por si mesmos, logo, dignos de serem recordados. A diferença entre um e outro é que enquanto Heródoto temia que o passado se perdesse irremediavelmente, Tucídides acreditava que a narrativa da guerra que testemunhara teria validez para os homens futuros. ${ }^{92}$

Para Arendt, a relação que o cristianismo estabeleceu entre vida e mundo é diametralmente oposta ao legado greco-latino. Para os cristãos, "nem o mundo nem o recorrente ciclo da vida são imortais, mas apenas o indivíduo vivo singular. É o mundo que se extinguirá; os homens viverão para sempre” (ARENDT, 1992, p. 83). O que Arendt revela é como o pensamento judaico-cristão transforma a historiografia grega e seu objeto, a guerra, em algo completamente distinto: uma história sagrada como manifestação de Deus no tempo e como drama da queda, da redenção e da salvação do homem. ${ }^{93}$ Ela dirá que Agostinho devotou 30 anos de vida para conceber A cidade de Deus e refutar a importância da queda de Roma, um evento mundano, isto, é secular, tanto para pagãos, quanto para cristãos. Assim, “jamais um evento secular poderia ou deveria ser de importância central para o homem. [...] A

\footnotetext{
91 Arendt (1992, p. 162) ressalta: “A fundação de um novo organismo político - quase um lugar comum na experiência dos gregos - tornou-se, para os romanos, o central, o decisivo e irrepetível princípio de toda sua história, um acontecimento único".

92 Murari Pires (1999, p. 202) sublinha que "a História tucididiana [...] realiza seu valor precipuamente enquanto obra escrita, a compor um saber que, primando pela clareza de sua objetivação, destina-se à fruição futura, que transcende o meramente momentâneo graças ao saber que sua narrativa dos acontecimentos decanta".

93 Bouretz (2011, p. 235) ressalta: "Chegando a impor ao mundo uma cronologia edificada sobre o acontecimento que fundamenta a sua fé, o cristianismo assegura uma parada no tempo, de modo que, a seus olhos, a significação da história torna-se conhecida de antemão. Ela representa uma passagem ou intervalo entre uma origem e um fim: o nascimento do Cristo e a parousia".
} 
história secular se repete, e a única história na qual eventos únicos e irrepetíveis têm lugar se inicia com Adão e termina com o nascimento e a morte de Cristo" (ARENDT, 1992, p. 98-9). Como Arendt (2011, p. 389) anota em seu diário em julho de 1953,

[...] la acción y la pasión como tal no son dignas de fama [...]. La historia es la acción de Dios y la reacción del hombre [...]. Es común a ambos, judíos y cristianos, el hecho de que no ven ningún sentido en la actuación puramente mundana, profana. [...] [Eles] sabían muy bien por qué no les importaba la interpretación de la historia profana: con la mejor voluntad no podía leerse en ella un acontecer tal como ellos lo querían y conocían.

Se, por um lado, a moderna consciência historiográfica reteve a noção de tempo retilíneo expressa na concepção cristã da história - criação, queda, encarnação, ressurreição, juízo final -, diferentemente da noção cíclica tipicamente grega, por outro lado, sua cronologia não exprimiria as formas da relação entre Deus e o homem, tampouco teria um começo (criação) e um fim (juízo final) determinados. Nesse sentido, ao contrário de uma visão amplamente arraigada entre historiadores, Arendt diverge da tese de que na origem da moderna consciência histórica estaria apenas a secularização de uma visão da história legada pelo cristianismo. Para ela, em "toda filosofia verdadeiramente cristã o homem é um "peregrino sobre a terra"” (ARENDT, 1992, p. 99), isto é, um estrangeiro no mundo cuja aspiração é salvar sua alma para viver eternamente na cidade de Deus e não na cidade dos homens. "Isto implica que a vida presente deve ser negligenciada em vista de um futuro absoluto que se constitui como a meta última da presente existência mundana do homem" (CORREIA, 2008, p. 22). Nessa visão escatológica, a única maneira de um cristão realizar algo digno e memorável é por meio de ações e palavras no interior dessa comunidade terrestre de peregrinos, a civitas Dei peregrinans, ${ }^{94}$ que é a Igreja. Isso fica claro no ensaio Agostinho e o protestantismo:

As vidas não têm suas próprias histórias autônomas; o princípio básico da mudança é a conversão, que divide uma vida em duas partes distintas. O que torna uma vida digna de ser lembrada, o que a converte num monumento para o cristão, não é nenhum princípio imanente naquela vida em si, mas algo totalmente outro: a graça de Deus (ARENDT, 2008b, p. 56).

\footnotetext{
${ }^{94}$ Entre a cidade do homem e a cidade de Deus existe, ainda no mundo, a civitas Dei peregrinans. A expressão, segundo Bodei, envolve o substantivo civitas (cidade), que, no século XIII, passou-se a designar como Estado ou comunidade dos cidadãos. Já o adjetivo peregrinans, segundo Bodei (2001, p. 19), "implica que nós homens sejamos peregrinos neste mundo. Num duplo sentido: enquanto 'estrangeiros' e enquanto 'peregrinos', fiéis que se dirigem [...] a algum santuário. A definição da civitas Dei peregrinans apresenta logicamente um paradoxo ou, retoricamente, um oximoro, dado que reenvia a uma cidade de não cidadãos, isto é, de todos os que vivem nesse mundo sem poder enraizar-se [...] do qual são hóspedes provisórios".
} 
A liberdade cristã, para Arendt, não é um desígnio da vida política (a liberdade de iniciar algo por conta própria), mas uma liberdade em relação à política. Como tal, a liberdade cristã torna-se, de fato, um atributo da interioridade: o livre-arbítrio. Ele significa a possibilidade de escolher entre coisas dadas, e não a liberdade de tomar uma iniciativa e interromper o fluxo "natural" das coisas. ${ }^{95}$

A terceira mudança, já na Antiguidade tardia, relaciona-se às especulações que surgem sobre a história como um movimento circular análogo ao da vida biológica. Especialmente após a queda do Império Romano, especulou-se sobre a história à maneira de um processo. Um processo de ascensão e declínio das nações, em que a singularidade dos eventos se perderia ante um inexorável movimento circular. Para Arendt (1992, p. 72), se por um lado essa espécie de reintegração da história "à imagem da vida biológica" representou que o mundo dos mortais fora reintegrado "no universo que existe para sempre", por outro, "em termos de Poesia e Historiografia antiga isso significou que o primitivo sentido de grandeza dos mortais, como algo distinto da grandeza indubitavelmente maior dos deuses e da natureza, se perdera".

O que guia as reflexões de Arendt é sua capacidade de selecionar momentos específicos que marcam o paulatino afastamento do homem da política. O que se percebe nas entrelinhas do texto é que Arendt está tratando da longa história de um esquecimento: o esquecimento da política. Ainda que não o nomeie explicitamente no ensaio sobre o conceito de História, o que ela traz à tona são flashes desse processo de alienação. A alienação do filósofo em relação à política, a alienação dos cristãos em relação à política ${ }^{96} \mathrm{e}$, por fim, se um dos critérios com que se media a ação para os antigos era a grandeza, a perda dessa dimensão na Antiguidade tardia. A esse processo de alienação Arendt consagrará amplo espaço em A condição humana, complementando sua análise polifônica da ação, agora direcionada à era moderna.

\footnotetext{
${ }^{95}$ Vale ressaltar que Arendt identifica outra dimensão da liberdade em Agostinho que não se confunde com o livre-arbítrio, pois está relacionada à natalidade. Pela importância que essa outra dimensão adquire no âmbito da educação, ela será abordada no capítulo seguinte. Vale notar que a própria Arendt (1992, p. 188), no ensaio Que é Liberdade?, sublinha: "Levantar a questão - o que é liberdade? - parece ser uma empresa irrealizável".

${ }^{96}$ Convém salientar que a atitude antipolítica que Arendt atribui ao cristianismo está referida apenas às primeiras centúrias cristãs. Arendt não nega que os impulsos antipolíticos do início da cristandade se transformaram com a institucionalização da Igreja. Agostinho, para ela, foi decisivo nessa transformação, "porque a própria linguagem veio em seu auxílio: em latim, a palavra 'viver' sempre coincidiu com inter homines esse, 'estar em companhia de homens', de modo que uma vida eterna, na interpretação romana, deveria significar que jamais homem nenhum teria de se apartar da companhia humana, ainda que na morte ele tivesse que abandonar a terra" (ARENDT, 1992, p. 107).
} 


\subsection{A alienação do homem em face do mundo}

O que guia esse inventário de Arendt sobre as transformações na consciência histórica é a noção do fazer que emerge na consciência historiográfica moderna. O fazer remetido à natureza do processo de fabricação, que, como tal, tem início e fim determinados, ao contrário das ações humanas, que podem ter muitos inícios, mas nenhum fim: "O motivo pelo qual jamais podemos prever com certeza o resultado e o fim de qualquer ação é simplesmente que a ação não tem fim" (ARENDT, 2010a, p. 291). Vale insistir nesse ponto, em parte porque aqueles que estavam à frente dos regimes totalitários, na perspectiva de Arendt, efetivamente fabricaram uma realidade por meio da ideologia e do terror. Estavam convictos de que tudo era possível, conforme ela sublinhou tantas vezes. Como é o próprio evento totalitário que ilumina suas reflexões histórico-políticas, interessa a Arendt retraçar os elementos que o constituíram, subitamente cristalizados em formas fixas e definidas. Como sublinha no prólogo de A condição humana,

[...] o propósito final da análise histórica é o de rastrear até a sua origem a moderna alienação do mundo, em sua dupla fuga da Terra para o universo e do mundo para o si-mesmo [self], a fim de chegar a uma compreensão da natureza da sociedade, como esta se desenvolvera e se apresentava no instante em que foi suplantada pelo advento de uma era nova e ainda desconhecida (ARENDT, 2010a, p. 7).

Apenas após concluir o exame fenomenológico das faculdades humanas do trabalho, da fabricação e da ação é que Arendt se dedica, no capítulo final de A condição humana, a compreender a "moderna alienação do mundo", examinada a partir desses processos de fuga distintos e complementares: a "fuga da Terra para o universo" e a fuga "do mundo para o si mesmo". Essa dupla fuga assume aqui um interesse especial, pois nela é possível perceber que as transformações sofridas no interior da vida ativa também são o esteio para o desenvolvimento da moderna consciência historiográfica.

Arendt distingue mundo moderno de era moderna. $\mathrm{O}$ mundo moderno nasce com as primeiras explosões atômicas. Já a origem da era moderna relaciona-se a três eventos que lhe definem o caráter e repercutem no processo de alienação do homem que Arendt deseja rastrear e compreender: os Descobrimentos Marítimos, a Reforma Protestante e a invenção do telescópio por Galileu. Cada evento transforma de maneira distinta a condição humana na Terra e, tomados em conjunto, marcam a origem da moderna alienação do mundo.

Ambos os processos de fuga - o da Terra para o universo e o do mundo para o si mesmo - resultam numa clara transformação da capacidade humana de examinar e investigar 
com rigor a realidade, de penetrar no segredo das coisas, pois alteram toda a tradição do pensamento no que diz respeito à relação entre o próximo e o distante, o sujeito e o mundo ao seu redor. Como nota Arendt (2010a, p. 312), aqueles que estavam à frente dos Descobrimentos "se fizeram ao mar para ampliar a Terra, não para reduzi-la a uma bola; e quando atenderam ao chamado distante, não tinham intenção alguma de abolir a distância”. Mas o fato é que o espaço e as distâncias, a partir de então e de modo contínuo, foram sendo abolidos, já que nenhum intervalo significativo de uma vida humana (semanas, meses ou até anos) é agora necessário para que um indivíduo se mova de um ponto a outro do planeta. Após séculos, os homens realmente tomaram posse daquilo que, aos primeiros aventureiros, parecia a um só tempo tentador e proibitivo. Hoje é possível conhecer os contornos do planeta como se conhecem as linhas da palma da mão.

Enfim, antes mesmo "que soubéssemos como contornar a Terra [...] já havíamos trazido o globo à nossa sala de estar, para tocá-lo com as mãos e girá-lo ante nossos olhos" (ARENDT, 2010a, p. 312). Arendt não se manifesta contra o fato de se ter o globo na sala de estar e poder tocá-lo e girá-lo. Reconhece que o conjunto de inventos da era moderna e seus desdobramentos realmente contribuíram para tornar próximo o que antes parecia distante. Mas convém ressaltar que o globo na sala (ou o Google Earth em nossos dias) é obra do homem, um artifício. Ao mirá-lo - e aqui pode estar a originalidade da análise de Arendt -, o homem vê menos um ponto qualquer e distante do planeta do que a si mesmo. A cena em si talvez resuma o primeiro processo de fuga a que Arendt se refere, uma vez que permite contemplarmos a Terra a partir de um ponto de vista imaginário no universo. Deixar a superfície terrestre significa "que qualquer diminuição de distância terrestre só pode ser conquistada ao preço de se colocar uma distância decisiva entre o homem e a Terra, de alienálo do seu ambiente terrestre imediato" (ARENDT, 2010a, p. 313).

$\mathrm{O}$ interesse de Arendt quanto aos desdobramentos da Reforma não se circunscreve à esfera religiosa, ainda que esteja a ela relacionado. Antes, remete à fuga do mundo para o si mesmo resultante das guerras religiosas que assolaram a Europa e devastaram cidades e do consequente processo de expropriação do campesinato como resultado imprevisto de outra expropriação: a das propriedades eclesiásticas.

Arendt argumenta que a moderna perda da fé religiosa - tema controverso que aqui se evitará - não fez com que os homens fossem arremessados de volta ao mundo, mas que se voltassem sobre si mesmos. Ela sublinha que a grandeza de Max Weber foi ter percebido que 
a ética protestante ${ }^{97}$ resultava na glorificação de uma atividade absolutamente mundana como o trabalho, logo, em conformidade com o espírito do capitalismo. Aos poucos, a ética protestante foi moldando uma conduta ascética, para não dizer uma regra, preocupada principalmente com os aspectos espirituais, sem que isso implicasse qualquer cuidado com o mundo, mas, ao contrário, "uma atividade cuja motivação mais profunda é [...] a preocupação e o cuidado com o si mesmo" (ARENDT, 2010a, p. 316).

É nesse mesmo tom que Arendt compreende as transformações suscitadas pelo advento da ciência moderna, outra variante do processo de fuga do mundo para o si mesmo. A dúvida cartesiana abala profundamente a crença reveladora dos sentidos humanos, aquela paixão de ver que caracterizava a relação que os gregos estabeleciam com o mundo ao seu redor. Ora, essa admiração pelas coisas tais como são, ao longo de séculos, também fez com que os homens especulassem e mirassem o universo com os "olhos do espírito", escutassemno com os "ouvidos do coração" e se guiassem pela "luz interior da razão", metáforas ancoradas na capacidade reveladora dos sentidos humanos para a apreensão da verdade das coisas. Porém, no alvorecer da época moderna e com o auxílio do telescópio, os homens voltaram "seus olhos corpóreos rumo ao universo" e aprenderam "que seus sentidos não eram adequados [...] [a esse universo], que sua experiência cotidiana [...] era uma constante fonte de erro e ilusão" (ARENDT, 1992, p. 85). Para os poetas antigos ou de acordo com as obras históricas de Heródoto e Tucídides, essa inadequação pareceria absurda, pois

[...] abro os meus olhos e contemplo a visão, escuto e ouço o som, movimento meu corpo e toco a tangibilidade do mundo. Se começamos a duvidar da fundamental veracidade e fidedignidade desse relacionamento, que evidentemente não exclui erros e ilusões, nenhuma das metáforas tradicionais para a verdade supra-sensível - seja os olhos do espírito que podem ver o céu das idéias ou a voz da consciência escutada pelo coração humano - poderá reter mais seu significado (ARENDT, 1992, p. 85).

Ora, quando Ulisses, na corte dos feácios, ouve do aedo Demódoco sua própria história, ele o louva - presenteia-o, inclusive, com uma bela posta de carne -, pois se diz surpreso com a maneira como Demódoco canta o infortúnio dos gregos, suas realizações e seus sofrimentos como se ele próprio tivesse visto ou escutado o relato de uma pluralidade de testemunhas. A onisciência da musa que soa por meio de Demódoco reforça não apenas o fato de que, simbolicamente, ela tudo vê e ouve: a musa representa a pluralidade de visões que permite "cantar os feitos dos troianos não menos que os dos aqueus, e louvar a glória de

\footnotetext{
${ }^{97}$ Arendt não faz nenhuma distinção entre luteranismo e calvinismo, assim como não faz nenhuma alusão aos conceitos de vocação ou predestinação, mas creio que eles estão implícitos no texto. Convém lembrar que o homem de espírito capitalista é calvinista e não luterano.
} 
Heitor não menos que a grandeza de Aquiles" (ARENDT, 1992, p. 81). E é essa pluralidade, e não os sentidos em si mesmos, o que garante a realidade do mundo, assim como é ela a garantia da imparcialidade homérica, que se desdobra em Heródoto e mais sutilmente em Tucídides.

Tais imparcialidade e objetividade, que Arendt tanto sublinha como características da poesia e da historiografia antigas, podem ser atestadas neste comentário de Tucídides (1982, p. 28, grifos nossos):

Quanto aos fatos da guerra, considerei meu dever relatá-los, não como apurados através de algum informante casual nem como me parecia provável, mas somente após investigar cada detalhe com o maior rigor possível, seja no caso de eventos dos quais eu mesmo participei, seja naqueles a respeito dos quais obtive informações de terceiros. O empenho em apurar os fatos se constitui numa tarefa laboriosa, pois as testemunhas oculares de vários eventos nem sempre faziam os mesmos relatos a respeito das mesmas coisas, mas variavam de acordo com suas simpatias por um lado ou pelo outro, ou de acordo com sua memória.

O que se depreende do comentário de Tucídides - e isso certamente o afasta de seu precursor Heródoto $^{98}$ - é que a tarefa laboriosa a que ele se entregou com suas testemunhas, que relatavam "de acordo com suas simpatias por um lado ou pelo outro, ou de acordo com sua memória", antes de representar um impedimento para a narrativa, assinalava a condição e o limite do empreendimento: relatar "com o maior rigor possível”. Daí Arendt (1992, p. 82) afirmar que os "discursos em que Tucídides articula as posições e interesses das partes em conflito são ainda um testemunho vivo do extraordinário grau de sua objetividade”. A objetividade de Tucídides, na perspectiva de Arendt (2010a, p. 70), assenta-se no fato de que apenas quando "as coisas podem ser vistas por muitas pessoas, em uma variedade de aspectos, sem mudar de identidade, [...] pode a realidade do mundo aparecer real e fidedignamente".

A despeito da reconhecida maestria de Tucídides nesse processo de inquirição ${ }^{99}$ e na posterior montagem da trama da guerra, selecionando aquilo que lhe parecia mais afeito à verdade dos fatos, a condição mesma do procedimento que empregou era a de aceitar parafraseando a crítica de Arendt ao cartesianismo - que aquilo que ele próprio testemunhara ou que suas testemunhas tinham visto ou ouvido de um terceiro, "evidentemente não exclui

\footnotetext{
98 Collingwood (1972, p. 59) observa: "Em Heródoto, temos uma tentativa de atingir um ponto de vista verdadeiramente histórico. Para ele, os acontecimentos são importantes em si mesmos e cognoscíveis por si mesmos. Mas já em Tucídides, os acontecimentos são importantes principalmente pela luz que lançam sobre entidades eternas e substanciais, das quais eles são meros acidentes. A corrente de pensamento histórico que fluía tão livremente em Heródoto começa a estancar".

${ }^{99}$ Conforme sublinha Romilly (1998, p. 15): "Tucídides relata fatos contemporâneos, sobre os quais lhe era fácil informar-se com minúcia, o que fez com uma atenção e uma imparcialidade universalmente reconhecidas".
} 
erros e ilusões". Ou, em outras palavras, que Heródoto, Tucídides e os gregos de forma geral "aprenderam a $[\ldots]$ olhar sobre o mesmo mundo do ponto de vista do outro, a ver o mesmo em aspectos bem diferentes e frequentemente opostos (ARENDT, 1992, p. 82).

Ocorre que as condições que possibilitaram o exercício da objetividade e da imparcialidade históricas já não se faziam presentes na era moderna. A imparcialidade homérica e a objetividade praticada por Tucídides guardavam um estreito vínculo com a experiência, com a realidade fenomênica do mundo e, fundamentalmente, com um sentido comum compartilhado. ${ }^{100} \mathrm{O}$ que se compartilhava eram alguns critérios (como os de louvor, grandeza, fama, coragem) a partir dos quais se conferia caráter extraordinário a algum feito: “O louvor, do qual provinha a glória e eventualmente a fama eterna, somente poderia ser outorgado [...] às coisas que possuíssem uma qualidade emergente e luminosa que as distinguisse de todas as demais" (ARENDT, 1992, p. 77).

O problema é que, na era moderna, a objetividade apartou-se da experiência e do senso comum compartilhado, isto é, perdeu o contato com a realidade, tornando-se mera e estéril questão acadêmica que, ao tempo de Droysen, ele já denunciava como eunuca. Para Arendt (1992, p. 81):

O problema da objetividade científica, tal como foi colocado no século XIX, devia-se à auto-incompreensão histórica e à confusão filosófica em tão larga medida que se tornou difícil reconhecer o verdadeiro problema em jogo, o problema da imparcialidade, de fato decisivo não somente para a "Ciência" da História como para toda historiografia oriunda da poesia e do contar histórias.

\subsection{Descartes e a dúvida moderna}

Numa perspectiva diametralmente oposta, o moderno conceito de história e sua pretensa objetividade são contemporâneos da descoberta de uma inadequação dos sentidos humanos para a apreensão da verdade, com a emergência das ciências naturais nos séculos XVI e XVII e com o advento da dúvida cartesiana na esteira dos experimentos ${ }^{101}$ de Galileu.

\footnotetext{
${ }^{100}$ Murari Pires (1999, p. 265) salienta que a crítica histórica moderna se equivoca ao projetar sobre a obra de Tucídides um padrão de objetividade que ele nunca pretendeu alcançar, tampouco seus contemporâneos: "para os antigos, a perspectiva do elemento de criação tucididiana não causava maior espanto ou rejeição, pelo contrário, entendendo a história como gênero literário, cabalmente afirmavam os discursos tucididianos como “invenções"”.

${ }^{101} \mathrm{Na}$ seção 42 de A condição humana, Arendt (2010a, p. 369) observa: "O emprego da experimentação para fins de conhecimento já era conseqüência da convicção de que o homem só pode conhecer aquilo que ele mesmo produz, pois essa convicção significava que ele poderia aprender algo acerca das coisas que não fez se representasse e imitasse os processos através dos quais essas coisas passaram a existir".
} 
Arendt (1992, p. 85) constata que a origem da desconfiança de Descartes foi a “justificadíssima perda de confiança na capacidade reveladora da verdade dos sentidos” e que a experiência subjacente a essa perda de confiança "foi a descoberta de que a Terra, contrariamente a toda experiência sensível direta, gira em torno do sol”, e não o contrário. Ela também aborda a questão em A condição humana:

Se o olho humano pode trair o homem a ponto de tantas gerações se enganarem ao crer que o Sol girava em torno da Terra, então a metáfora dos olhos da mente já não podia ser conservada; baseava-se, embora implicitamente e mesmo quando usada em oposição aos sentidos, em uma confiança máxima na visão corporal (ARENDT, 2010a, p. 342-3).

A perda dessa confiança nos sentidos implicou a concomitante perda da certeza que antes acompanhava tudo aquilo que era autoevidente, "credo comum a toda Antiguidade pagã e hebraica, à filosofia secular e à filosofia cristã” (p. 344). O que aqui convém destacar é como a dúvida moderna acerca da capacidade reveladora dos sentidos fará dos processos, e não das coisas que se revelam por si mesmas, a pedra de toque da moderna concepção de ciência, produzindo uma mudança de ênfase a partir da busca do porquê e do quê para o como as coisas vieram a ser o que são. O caráter radical da filosofia de Descartes enraíza-se num novo tratamento da relação entre pensamento e realidade. A introspecção cartesiana, a precedência do sujeito no processo de conhecimento, significa que o pensar, desde que metodicamente conduzido, encontra primeiro em si mesmo os critérios que permitirão tomar algo por verdadeiro. Em outras palavras, que a razão humana se vê envolvida num jogo com ela mesma, com conteúdos que a própria mente produziu, esquecida da realidade. Daí Arendt sublinhar que o método da introspecção cartesiana implicou a fuga do mundo para o simesmo. Na interpretação que dá ao cogito ("penso, logo existo"), ela observa:

O homem leva dentro de si mesmo a sua certeza, a certeza de sua existência; o mero funcionamento da consciência, embora talvez não possa garantir uma realidade mundana dada aos sentidos e à razão, confirma indubitavelmente a realidade das sensações e do raciocínio, isto é, a realidade dos processos que ocorrem na mente (ARENDT, 2010a, p. 350).

Mas a que preço? - questiona Arendt. Não, obviamente, de os homens aceitarem a inevitabilidade dos sentidos, do testemunho e da razão humana, mas ao preço da certeza que antes os acompanhava. É sintomático, e de importância vital para Arendt, que entre Galileu e o céu que contemplava se interpusesse um artifício humano: o telescópio. O que esse instrumento revela não é perceptível sem seu auxílio, o que implica dizer que os segredos da natureza não se revelam de imediato aos sentidos humanos. O gesto de Galileu, ao direcionar 
as lentes de seu instrumento para o universo e estabelecer um fato demonstrável, significou colocar ao alcance dos sentidos algo que estava além deles, "na melhor das hipóteses [...], aberto às incertezas da especulação e da imaginação" (ARENDT, 2010a, p. 324) daqueles que o precederam - consumando, assim, o antigo desejo de Arquimedes de um ponto fora da Terra onde o homem pudesse apoiar uma alavanca para erguer o mundo e poder contemplá-lo.

A conclusão parcial de Arendt (2010a, p. 354-5) em relação ao duplo processo de fuga, "da Terra para o universo e do mundo para o si-mesmo", é que se o primeiro processo possibilitado pelo ponto arquimediano -, como ela diz, ainda foi realizado "por uma criatura presa à Terra", o segundo - o da a introspecção cartesiana - implicou deslocar esse ponto "para dentro do próprio homem". Nesse deslocamento, os fenômenos deixam de aparecer em si e por si mesmos, e a ciência moderna vai se incumbir de produzir os fenômenos que quer enxergar:

Uma das consequiências mais plausíveis da dúvida cartesiana era o abandono da tentativa de compreender a natureza e, de modo geral, adquirir conhecimento acerca de coisas não produzidas pelo homem e, ao invés disso, o voltar-se exclusivamente para as coisas que deviam a existência ao homem (ARENDT, 2010a, p. 372).

\subsection{G. Vico: verum et factum convertuntur}

Entre os pensadores que se voltaram "exclusivamente para as coisas que deviam a existência ao homem", Vico, o autor de Ciência nova, de 1725, ocupa um lugar proeminente, uma vez que também se colocou como tarefa analisar as possibilidades e os limites do conhecimento. Há um consenso entre os intérpretes de Vico de que se trata de um pensador um tanto fora de seu tempo, incompreendido por seus contemporâneos e cuja escrita um tanto barroca afugentava os leitores.

O historiador Peter Burke diz que a influência de Vico se fez notar em pensadores tão distintos como Herder, Goethe, Michelet (que o traduziu e dizia ter nascido de Vico), Marx, Cassirer, Auerbach, Joyce ("minha imaginação cresce quando leio Vico") e Croce. ${ }^{102} \mathrm{O}$ fato de que pensadores tão distintos tenham manifestado apreço pelas ideias de Vico sugere certo ecletismo em sua obra. ${ }^{103}$ A própria Arendt (1992, p. 111) reconhece que a influência de Vico seria sentida "mais de duas gerações após a sua morte". Não foi possível determinar o grau da influência de Vico na reflexão histórica de Arendt, mas é provávelmente maior do que ela

${ }^{102}$ Cf. BURKE, 1997b, p. 17.

${ }^{103}$ Devemos essa observação à arguição do professor Elias Thomé Saliba, por ocasião do exame de qualificação deste trabalho. 
própria admite, especialmente quanto ao tema da imaginação, que os intérpretes da autora atribuem à influência de Kant e que ela aborda de forma mais detida nas Lições. Trata-se de um tema que tem profundas ressonâncias na obra de Arendt, pois vai ao cerne do trabalho historiográfico, uma vez que a imaginação, diferentemente da pura fantasia, é a capacidade de tornar presente o que está ausente. ${ }^{104}$

Burke (1997b, p. 85-6, grifo nosso) ainda recorda que Vico "tinha um notável talento para ver o geral no particular e, assim, elaborar hipóteses que se revelaram férteis. Este é um lembrete salutar à nossa comunidade científica sobre a importância da imaginação histórica". Ora, a partir do que se viu até aqui, não se pode dizer exatamente o mesmo em relação a Arendt?

Convém notar que ela conhecia a obra do historiador inglês Collingwood, tradutor e divulgador da obra de Vico. Fuster Peiró (2005, p. 409), que examinou os papéis de Arendt na Biblioteca do Congresso Americano, comenta que

Arendt não foi a única pensadora a advertir sobre a importância da imaginação nas ciências históricas. Antes dela, o filósofo inglês Robin George Collingwood, seguindo o empreendimento de Kant, vai conceder à imaginação um papel central ao trabalho do historiador. ${ }^{105}$

Para Collingwood (1972, p. 299), a principal tarefa da imaginação histórica é a de “imaginar o passado: não um objeto de possível percepção, uma vez que já não existe, mas um objeto suscetível de se tornar, através da imaginação histórica, um objeto do nosso pensamento". Apesar da importância da imaginação histórica para Arendt, ela parece procurar em Vico menos o autor de "notável talento para ver o geral no particular", conforme apontou Burke, e mais o pai da moderna consciência historiográfica para quem só podemos conhecer algo quando nós o fazemos. Menos as "hipóteses que se revelaram férteis", e mais o antípoda de Descartes, para quem o estudo da história (das letras) seria um desperdício, já que não proporcionaria nenhum conhecimento verdadeiro. Nesse aspecto, Arendt segue Collingwood (1972, p. 88-9), para quem Vico estava à procura de um princípio capaz de "distinguir aquilo que pode ser conhecido daquilo que não pode ser", o que encontrará na doutrina

\footnotetext{
${ }^{104}$ Cassirer (1997, p. 294, grifo nosso) sublinha: "Os grandes historiadores [...] não carecem de "espírito poético. É da perspicácia para a realidade empírica das coisas, combinada ao talento livre da imaginação, que depende a síntese ou a sinopse histórica".

105 Na mesma página, Fuster Peiró comenta numa nota que Arendt faz uma referência crítica à obra de Collingwood (1889-1943), bem como a M. Oakeshott e E. R. Carr em dois cursos inéditos que têm o mesmo título Political Experiences in the Twentieth Century: um deles em 1965, na Universidade de Cornell, e o outro na primavera de 1968, na New School for Social Research.
} 
[...] de que verum et factum convertuntur: isto é, a condição de ser capaz de conhecer verdadeiramente qualquer coisa, de compreendê-la como oposta à sua simples percepção, é que o próprio conhecedor a tenha criado. [...] Conclui-se do princípio do verum-factum que a história - que é algo feito enfaticamente pelo espírito humano - está especialmente apta a ser objeto de conhecimento humano.

Assim, na perspectiva de Vico, da mesma forma que Deus pode conhecer a natureza porque Ele a fez, os homens podem conhecer a história porque a fizeram. Trata-se, portanto, de um empreendimento com profundo caráter epistemológico, uma vez que entre os objetivos de Vico estava o desenvolvimento de um saber racional acerca da sociedade civil com o fito de compreender a autoria das práticas humanas. Assim, diferentemente de Agostinho, Vico abria espaço à liberdade humana da ação do homem na história, ainda que permaneça latente em sua obra uma tensão entre a liberdade humana e a providência divina.

Para Arendt (1992, p. 88), a atitude pragmática de Vico “já é a razão inteiramente articulada pela qual voltou sua atenção para a História e se tornou assim um dos pais da moderna consciência histórica". Tal atitude implicou um deslocamento da ênfase "do interesse das coisas para o interesse em processos, dos quais as coisas iriam em breve se tornar subprodutos quase que acidentais" (p. 88, grifo nosso). ${ }^{106} \mathrm{O}$ alegado pragmatismo de Vico, porém, tinha uma importância meramente teórica:

Para Vico, como mais tarde para Hegel, a importância do conceito de História era basicamente teórica. Jamais ocorreu a nenhum deles aplicar este conceito utilizando-o diretamente como um princípio de ação. Concebiam a verdade como sendo revelada ao vislumbre contemplativo e retrospectivo do historiador, o qual, por ser capaz de ver o processo como um todo, estaria em posição de desprezar os "desígnios estreitos" dos homens de ação, concentrando-se em vez disso nos "desígnios superiores", que se realizam por detrás de suas costas (ARENDT, 1992, p. 112).

Entretanto, se para Vico e para Hegel o conceito de fazer história não era concebido como princípio de ação, isto é, a ação não era concebida prospectivamente, à imagem de um processo de fabricação, mas sim retrospectivamente - e só nesse sentido retrospectivo pode-se falar que o historiador fabrica uma história, que ele verdadeiramente a faz como autor -, o mesmo não se deu em Marx. Para Arendt, o sentido da história, por princípio algo desconhecido e incognoscível, transformou-se em Marx numa finalidade da ação. Explorando essa indistinção entre sentido e finalidade, Arendt (1992, p. 114) vai procurar demonstrar que,

106 O interesse que a questão desperta para este trabalho - a ser retomado no último capítulo - é que um dos pilares da educação moderna é justamente a crença de que "só é possível conhecer e compreender aquilo que nós mesmos fazemos" (ARENDT, 1992, p. 232). 
quando "os sentidos são degradados em fins, segue-se que os próprios fins não mais são compreendidos, de modo que, finalmente, todos os fins são degradados e se tornam meios".

\title{
3.5. Marx e a substituição da ação (práxis) pela fabricação (poiésis)
}

Arendt sempre foi muito cuidadosa na maneira de abordar a obra de Marx. ${ }^{107} \mathrm{Na}$ primeira metade dos anos 1950, após a publicação de Origens do totalitarismo, ela mergulha no estudo de Marx, num momento em que os Estados Unidos viviam o período de caça às bruxas do macarthismo, implacável perseguição política aos comunistas liderada pelo então senador republicano do Wisconsin, Joseph McCarthy (1907-1957). ${ }^{108}$

Muitas das críticas dirigidas a Arendt após a publicação de Origens do totalitarismo relacionavam-se ao tratamento desigual dado por ela na obra aos totalitarismos nazista e stalinista, com grande ênfase no primeiro. De fato, esse desequilíbrio - Arendt o justifica em parte pela ausência de fontes, ou ao menos de fontes confiáveis, no novo prefácio que redigiu para a terceira parte de Origens, em 1966 - é consensual mesmo entre os intérpretes que simpatizam com a análise de Arendt sobre o totalitarismo. Consequência direta ou não de tais críticas, nos anos que se seguiram à publicação da obra Arendt se empenhou num estudo concebido como complementação a Origens - mas que nunca logrou concluir conforme o projeto original, chamado de Elementos totalitários do marxismo. Young-Bruehl transcreve um trecho do pedido de subvenção feito por Arendt à Fundação Guggenheim, em 1952, com vistas a subsidiar o referido estudo. Nele, Arendt (apud YOUNG-BRUEHL, 1997, p. 253) declara:

\begin{abstract}
A lacuna mais séria de As origens do totalitarismo é a falta de uma análise histórica e conceitual da moldura ideológica do bolchevismo. Essa omissão foi deliberada. [...] A originalidade chocante do totalitarismo, o fato de suas ideologias e métodos de governo terem sido inteiramente sem precedentes e de suas causas desafiarem uma explicação adequada nos termos históricos usuais, é facilmente negligenciável quando se enfatiza demais o único elemento que tem por trás de si uma tradição respeitável e cuja discussão
\end{abstract}

107 Em A condição humana, Arendt (2010a, p. 97) sublinha: "No capítulo seguinte, Karl Marx será criticado. Isso é lamentável em uma época em que tantos escritores que outrora ganharam a vida pela apropriação, tácita ou explícita, da grande riqueza das idéias e intuições marxianas, decidiram tornar-se antimarxistas profissionais". Para um exame da questão, ver DUARTE, 2000, p. 77-120, e CORREIA, 2005, p.164-172.

108 Para não correr o risco de ser confundida com essa maré anticomunista, Arendt recorre a uma bela passagem de um célebre ensaio de Benjamin Constant (1985, p. 16-7), fazendo suas as palavras dele, então referidas a Rousseau, e não a Marx: "Evitarei, é claro, juntar-me aos detratores de um grande homem. Quando o acaso me faz aparentemente concordar com eles em um único ponto, desconfio de mim mesmo; e, para consolar-me de parecer, por um instante, de sua opinião, sobre uma única e parcial questão preciso desautorizar e descolorir quanto posso a esses supostos auxiliares". 
crítica requer a crítica de alguns dos princípios básicos da filosofia política do Ocidente - o marxismo.

Young-Bruehl ainda faz um inventário de como o estudo de Arendt sobre Marx, depois rebatizado de Karl Marx e a grande tradição (o que revela que, para ela, não era possível abordar Marx sem tocar na tradição), foi se transformando em meio a uma série de palestras e seminários que Arendt realizou em universidades americanas e europeias, experiências que considerava "uma excelente caixa de ressonância" e para as quais se sentia agraciada. ${ }^{109} \mathrm{O}$ fato é que, num curto período de tempo, Arendt entregaria para publicação as obras A condição humana (1958), Entre o passado e o futuro (1961) e Sobre a revolução (1963), que, segundo Young-Bruehl (1997, p. 256), "haviam brotado do trabalho original sobre o marxismo" com o qual Arendt se ocupou entre 1952 e 1956.

O inventário de Young-Bruehl sobre esses anos contribui para aclarar o lugar que Arendt originalmente havia pensado para dois ensaios sobre teoria da história publicados anos mais tarde sob os títulos História e imortalidade (1957) e O conceito moderno de história (1958). Ambos viriam a se fundir, em 1961, na coletânea Entre o passado e o futuro, agora sob o título $O$ conceito de história: antigo e moderno, ${ }^{110}$ ao qual este trabalho vem fazendo constantes referências. Ainda segundo Young-Bruehl, os dois ensaios originais conformariam cada qual um capítulo da primeira parte do projeto do livro não concluído sobre o marxismo e, ali, Arendt (1992, p. 112-3) sustenta que, por não distinguir um sentido de um fim, o historiador e filósofo Marx se politizou, ao tomar

[...] o significado hegeliano de toda história, o progressivo desdobramento e realização da idéia de Liberdade, como sendo um fim da ação humana, e

\footnotetext{
${ }^{109}$ Nos agradecimentos da obra A condição humana, Arendt (2010a, p. 407) diz: "Ainda hoje sou muito grata pela paciência e pelo incentivo com os quais essas primeiras tentativas [ela se refere às palestras e aos seminários na Universidade de Princiton (1953), Chigago (1956) e no exterior] foram acolhidas e pela vívida troca de idéias".

110 No inverno de 1957, Arendt publicou o ensaio History and imortality na Partisan Review. No ano seguinte, na Review of Politics, ela voltaria ao tema da história em The modern concept of history. Ainda em 1957, uma publicação alemã, Fragwnerdige Traditionsbestaende im politichen Denken der Gegenwart, trazia quatro ensaios concebidos originalmente em inglês, entre os quais History and imortality, que na versão alemã feita por Charlotte Beradt aparece com o título Natureza e história. Tudo leva a crer que Arendt reaproveitou os dois ensaios por ocasião da publicação de Between past and future: six exercises in political thought, em 1961, "fundindo-os" e retocando-os no ensaio The concept of history: ancient and modern. Ele é o segundo mais extenso da obra - quarenta páginas ante quarenta e uma do ensaio What is authority? - e está subdividido em três partes e um epílogo: as partes receberam os subtítulos: I - History and nature; II - History and earthly immortality; e III - History and politics. Há, entretanto, uma versão em espanhol do ensaio History and imortality" em Hannah Arendt: de la história a la acción, coletânea de ensaios de Arendt organizada e traduzida por Fina Birulés. Comparando a versão em espanhol de History and imortality com a tradução portuguesa do ensaio The concept of history: ancient and modern, de Between past and future, foi possível perceber que as partes II, III e o epílogo correspondem, em linhas gerais, ao ensaio History and imortality. Fica sobrando, portanto, a parte I do ensaio The concept of history: ancient and modern, intitulada History and nature. Talvez ela corresponda ao ensaio publicado na Review of Politics de 1958, intitulado The modern concept of history.
} 
quando, além disso, em conformidade com a tradição, considerou esse "fim" último como o produto final de um processo de fabricação.

Ora, o significado hegeliano de história (e a história está no centro da filosofia de Hegel) só aparece ao filósofo retrospectivamente. Em outras palavras, ainda que os homens não tenham a exata consciência daquilo que fazem, existe, aos olhos de Hegel, uma espécie de força invisível - tal qual as forças do mercado econômico para Adam Smith - atuando por trás dos homens a fim de garantir "o progressivo desdobramento e realização da idéia de Liberdade".

A filosofia, a despeito de admitir o devir, o vir-a-ser, o instável, sempre tentou diminuí-lo em favor da estabilidade, do permanente, do ser. Sob esse aspecto, a filosofia da história de Hegel admite que a verdade é um processo, um movimento. Ainda que a "idéia de Liberdade" esteja dada de antemão, é só na manifestação concreta da temporalidade, isto é, nas etapas que o espírito percorre em sua teleologia, que ela pode ser captada pelo olhar retrospectivo do filósofo da história. Quando Marx toma a história à imagem da fabricação, isto é, de um processo cujos início e fim já são conhecidos de antemão, ele acaba por considerar que a história é o autêntico veículo por meio do qual a liberdade política se realiza. De forma que fazer política passa a ser um equivalente a fazer história, a atuar historicamente.

O problema é que a liberdade política, nos termos definidos por Arendt, não é apenas a liberdade de agir e iniciar algo inusitado. É algo mais, porque o ator nunca age sozinho, mas em meio a uma trama de relações humanas e, ainda que possa imprimir à sua ação individual um objetivo determinado, o máximo que ele pode fazer (esse iniciador) é forçar as coisas em determinada direção. Mas ao ator não é dada a possibilidade de antever tais resultados, de forma que o preço da liberdade é a ausência de garantia quanto aos resultados práticos das ações. Ao determinar de antemão o ponto de chegada das ações, Marx sacrificou a espontaneidade, a pluralidade e, por que não dizer, o resultado imprevisto das ações. E por quê? Porque a singularidade da ação política (a revelação de um quem por meio da palavra) ou a particularidade de um acontecimento se perde na teleologia de Marx. O sentido que só se revela ao final de uma ação torna-se a finalidade dessa própria ação.

A cautela de Arendt na abordagem de Marx, ao evitar qualquer associação direta entre o autor de $O$ capital e o totalitarismo, é sublinhada na carta à Fundação Guggenheim, pois havia percebido que "para compreender o lugar de Marx era necessário compreender a própria tradição, assim como a relação da tradição com o fenômeno totalitário" (apud CORREIA, 2005, p. 166). Duarte (2000, p. 79) também sublinha que, "se Marx não pode ser culpado por essa nova forma de governo [o totalitarismo], também não foi por acaso que o estalinismo 
assumiu o marxismo como sua ideologia oficial [...] como jamais antes ocorrera às idéias de um pensador". A própria Arendt (1992, p. 54) deixa isso bem claro no ensaio A tradição e a época moderna:

Responsabilizar os pensadores da idade moderna, especialmente os rebeldes [Kierkegaard, Marx e Nietzsche] contra a tradição do século XIX, pela estrutura e pelas condições do século XX é ainda mais perigoso que injusto. As implicações manifestas no evento concreto da dominação totalitária vão muito além das mais radicais ou ousadas idéias de quaisquer desses pensadores. A grandeza deles repousa no fato de terem percebido o seu mundo como um mundo invadido por problemas e perplexidades novas com os quais nossa tradição de pensamento era incapaz de lidar.

Importa notar aqui como a categoria da causalidade é recusada por Arendt - buscar as origens do totalitarismo não significava buscar suas causas, equívoco ao qual o título do livro induz, como ela própria reconheceu na réplica da resenha de Eric Voegelin ${ }^{111}$ - em sua busca por compreender os elementos totalitários do marxismo. Marx certamente nunca imaginou que sua obra seria dogmatizada por Stalin. No entanto, todo pensador sabe que suas ideias podem ser bem ou mal utilizadas, pois os livros não vêm acompanhados de manuais de instruções. $^{112}$

Para Arendt (1993a, p. 49), a injustiça da atribuição da culpa é que o significado de qualquer evento excede as causas que se possam a ele atribuir: "Somente quando algo irrevogável aconteceu é que podemos retraçar sua história. $\mathrm{O}$ acontecimento ilumina o próprio passado; jamais pode ser deduzido dele”. Assim, não é possível deduzir pura e simplesmente que existem, de forma latente na obra de Marx, certos elementos que levariam ao totalitarismo. Ao contrário, é o evento totalitário como algo irrevogável que pode esclarecer a suposta presença daqueles elementos totalitários, senão na obra de Marx, em algumas ideiaschave de seu pensamento, entre elas a de que a violência é a parteira da história.

As transformações operadas ao longo da Revolução Industrial resultaram na elevação do trabalho à vista de todos a um plano até então inimaginável. O mundo que daí emergiu é

\footnotetext{
111 "O que eu fiz [...] foi descobrir os elementos principais do totalitarismo e analisá-los em termos históricos, remontando esses elementos na história até onde julguei adequado e necessário. Ou seja, não escrevi uma história do totalitarismo, e sim uma análise em termos históricos; não escrevi uma história do anti-semitismo ou do imperialismo, mas analisei o elemento de ódio aos judeus e o elemento de expansão porque ambos ainda eram claramente visíveis e desempenhavam um papel decisivo no próprio fenômeno totalitário. Assim, o livro não trata de fato das 'origens' do totalitarismo - como infelizmente anuncia o título -, mas apresenta uma exposição histórica dos elementos que se cristalizaram no totalitarismo" (ARENDT, 2008b, p. 419).

${ }^{112}$ Há exceções. Vale notar que uma das exigências do MEC para a aquisição de livros didáticos via PNLD (Programa Nacional do Livro Didático) é a presença, junto ao livro, de um manual do professor. O que evidencia melhor o declínio ou mesmo o desaparecimento da autoridade do professor nos termos em que Arendt (1992) a define no ensaio Que é autoridade? e retoma em A crise na educação.
} 
guiado pela lógica do homo faber, uma lógica implacavelmente utilitária, instrumental. "Aqui é realmente verdade que o fim justifica os meios; mais que isso, o fim produz e organiza os meios. [...] Durante o processo da obra, tudo é julgado em termos de adequação e serventia [usefulness] em relação ao fim desejado e nada mais" (ARENDT, 2010a, p. 191).

Uma vez que o produto final do processo de fabricação vem ao mundo, ele já não é um fim em si mesmo, pois, para demonstrar sua utilidade, transforma-se novamente em meio para a consecução de outros fins que não aquele que presidiu seu aparecimento. "Em outras palavras, em um mundo estritamente utilitário, todos os fins são constrangidos a serem de curta duração e a transformarem-se em meios para alcançar outros fins” (p. 191-2). Daí Arendt afirmar que a perplexidade do utilitarismo

[...] é que ele é capturado pela cadeia interminável de meios e fins sem jamais chegar a algum princípio que possa justificar a categoria de meios e fins, isto é, a categoria da própria utilidade. O "a fim de" torna-se o conteúdo do "em razão de"; em outras palavras, a utilidade instituída como significado gera a ausência de significado (p. 192).

O que parece estar em jogo, para Arendt, não é exatamente a instrumentalidade em si mesma - ela própria reconhece que, no âmbito das atividades humanas, a fabricação só poderia ser regida por uma lógica instrumental baseada em meios e fins -, mas o fato de a lógica do homo faber se impor como critério absoluto para a vida e o mundo, numa espécie de imperialismo da utilidade, fazendo esquecer que todo objeto - o exemplo das obras de arte é paradigmático para ela - transcende sua mera utilidade ou funcionalidade. ${ }^{113}$

Marx teve o mérito de perceber a lógica inerente ao homo faber, ainda que não tenha percebido, segundo Arendt, a diferença entre trabalho e fabricação - uma distinção pouco usual, como ela mesma reconhece, mas fortemente enraizada no testemunho da linguagem. $\mathrm{Na}$ interpretação de Arendt, para Marx há um único conceito, o de trabalho, e ele define o homem menos como um homo faber, e mais como um animal laborans, cujo matabolismo vital se mistura ao ciclo recorrente da natureza. Ora, enquanto os produtos da atividade da fabricação se prestam ao uso, eles realmente se integram ao artifício humano, uma vez que emprestam durabilidade e se integram ao tempo em que transcorre a vida de um indivíduo. Assim, o homo faber é primordialmente um edificador de mundo, diferentemente do animal laborans, cuja lógica é o consumo repetido e cíclico a fim de reproduzir sua própria energia vital num contínuo metabolismo homem-natureza.

${ }^{113}$ Cf. AMIEL, 1997, p. 65 e ss. 
O tema da funcionalidade como motor da sociedade não aparece primeiramente em $A$ condição humana. Num ensaio de 1944, intitulado Franz Kafka: uma reavaliação, Arendt (2008b, p. 98) já notava que o personagem K., de O processo, vivia uma espécie de pesadelo por estar imerso numa lógica funcional: “A força da máquina em que K. [...] é apanhado reside precisamente nessa aparência de necessidade, de um lado, e na admiração das pessoas pela necessidade, de outro". O problema - que Kafka percebeu e levou para suas obras, e que creio permear a narrativa arendtiana - é que, ao se tornar um funcionário dessa máquina administrativa que são os atuais governos e empresas, o homem se torna "um agente da lei natural da ruína" (p. 101), ao submeter-se à lógica que preside a vida do animal laborans, uma vez que o destino natural de qualquer obra assim produzida é ser consumida pelo tempo, a menos que os homens interrompam esse processo por meio da capacidade de agir em conjunto.

O problema, dirá Arendt (2010a, p. 197), é que se os critérios do homo faber passam a presidir o mundo, a dar o tom às relações políticas, ele "finalmente se servirá de tudo e considerará tudo o que existe como simples meios à sua disposição". Talvez este tenha sido um dos equívocos de Marx, aos olhos de Arendt: as ações humanas passam a ser tomadas como simples meio a partir do qual os homens fabricam a própria história. Como sublinha Drucker (2000, p. 206), “quando o modo utilitarista de pensar invade todos os domínios, nada pode conservar uma grandeza intrínseca".

Num corajoso ensaio de março de 1953, Os ex-comunistas, publicado no The Common Weal, Arendt (2008b, p. 412) sublinha:

Podemos agir politicamente, mas não podemos "fazer história" [...]. A confusão entre ação política e fazer história remonta a Marx. Depois que Hegel interpretou a história da humanidade, Marx tinha esperanças de poder "mudar o mundo", isto é, fazer o futuro da humanidade. O marxismo pode se transformar numa ideologia totalitária devido a esta distorção, ou incompreensão, da ação política com o fazer a história.

Em sua perspectiva, a máxima de Marx segundo a qual os filósofos até então haviam se ocupado em interpretar o mundo e agora era preciso transformá-lo - o que nos remete para a relação entre filosofia e política - revela justamente seu desejo de realizar a própria filosofia na história. ${ }^{114}$ Para Arendt, o que caracteriza a atividade da fabricação é justamente o fato de que a natureza precisa ser violentada a fim de ser transformada num artifício humano, em cultura. Ao olhar para a história tendo como modelo o processo de fabricação, Marx transpôs

${ }^{114}$ Arendt observa (2010a, p. 373, n. 62), numa nota, que "sempre que a era moderna tinha razão de esperar por uma nova filosofia política, recebia, ao invés, uma filosofia da história". 
a lógica do artífice, que antes de iniciar a transformação de seu objeto já o tem presente como ideia (eidos) e a executa. De acordo com Arendt (2010a, p. 275), isso só demonstra a impaciência de Marx para com a história e a tentação de buscar um substituto para o resultado sempre imprevisível das ações humanas:

Tanto os homens de ação quanto os pensadores sempre foram tentados a procurar um substituto para a ação, na esperança de que o domínio dos assuntos humanos pudesse escapar da acidentalidade e da irresponsabilidade moral inerente à pluralidade dos agentes. A notável monotonia das soluções propostas no decorrer da história escrita atesta a simplicidade elementar da questão.

O que interessa captar da análise de Arendt é que poucos filósofos políticos tiveram disposição para aceitar que a dádiva da liberdade política implica aceitar a desoladora contingência dos assuntos humanos. Tal como destaca Martínez (1994, p. 114):

La difícil tarea del historiador y el narrador no puede ser otra que la de contribuir a la fundamentación del futuro protegiendo un espacio duradero de sentido humano e inspiración de valores para la acción mediante el recuerdo preservado a través de un ejercicio ético y estético de enjuiciamiento y rememoración. [...] no es al historiador a quien corresponde la fijación de objetivos para el futuro, porque son siempre los hombres mismos quienes al actuar y manifestarse, dan lugar y ponen nombre a lo que hacen.

Ainda que essa impaciência com a história e a política não seja um atributo específico de Marx, Arendt reserva a ele um lugar distinto entre os teóricos em que a noção de fazer a história se abrigou, pois apenas Marx percebeu que, ao se tomar a história à imagem de um processo de fabricação, “deve sobrevir um momento em que esse 'objeto' é completado, e que, desde que se imagina ser possível 'fazer a história' não se pode escapar à conseqüência de que haverá um fim para a história" (ARENDT, 1992, p. 114).

A mesma ideia aparece no ensaio Compreensão e política:

O fim, em qualquer sentido estrito e definitivo da palavra, só poderia ser o desaparecimento do homem da face da Terra. Pois o que quer que o historiador chame de fim, seja o fim de um período, de uma tradição, ou de toda uma civilização, ele é um novo começo para aqueles que estão vivos (ARENDT, 1993a, p. 50-1).

Para Arendt, ao contrário, a história não tem um fim, ainda que possa ter muitos começos. Origens do totalitarismo se encerra com estas palavras:

Mas permanece também a verdade de que todo fim na história constitui necessariamente um novo começo; esse começo é a promessa, a única 
"mensagem" que o fim pode produzir [...]. O começo [...], politicamente, equivale à liberdade do homem [...]. Cada novo nascimento garante esse começo; ele é, na verdade, cada um de nós (ARENDT, 1989, p. 531).

Anos depois, as relações entre nascimento, liberdade e política voltariam a ocupar as reflexões de Arendt, agora dirigidas à educação. De alguma forma, Arendt tinha a intenção de “devolver à infância a sua presença enigmática e de encontrar a medida da nossa responsabilidade pela resposta, ante a exigência que esse enigma leva consigo" (LARROSA, 2010, p. 186). Uma vez mais, seus pensamentos principiavam pelo estabelecimento de distinções: nascimento não é natalidade, política não é educação, nascer para a vida não é nascer para o mundo, autoridade não é autoritarismo. E, para efeitos deste trabalho, poder-seia acrescentar: ensino de História não é política, aluno não é historiador-mirim. Os dois capítulos a seguir se movem em torno destas distinções com o propósito de ir somando elementos para uma reconsideração do sentido formativo do ensino de História.

Até aqui foi possível esboçar como Arendt rastreou historicamente o antigo desejo platônico de encontrar um substituto para a ação (práxis) por meio da segurança da fabricação (poiésis). O tema em si é vasto, pois envolve nada mais nada menos que uma reconsideração de toda a tradição da filosofia política ocidental e do ocaso em torno da liberdade política.

O quarto capítulo toma como ponto de partida a pertinência da análise de Arendt sobre o ocaso da tradição. O transporte efetuado pela tradição ao transpor o funcionamento da fabricação para a ação resultou num esvanecimento da política. A partir dessa tese, levanta-se a hipótese de que um transporte análogo ocorreu no campo das relações pedagógicas, inclusive no âmbito do ensino de História, elegendo-se a instituição escolar como um novo espaço da ação política, do fazer a história.

Essa ruptura de fronteira entre política e educação implica retomar a distinção proposta por Arendt no ensaio A crise na educação, de 1958. A hipótese sobre o transporte toma como referência os discursos sobre o ensino de História, a disciplina escolarizável mais permeável à política. Trata-se de analisar se tais discursos acabam por fundir os dois âmbitos. Para o caso de se revelar uma amálgama entre eles, qual é o sentido formativo que emerge de tais discursos? À luz da distinção proposta por Arendt, não se poderia pleitear um sentido alternativo? 


\section{Política e educação: fronteiras}

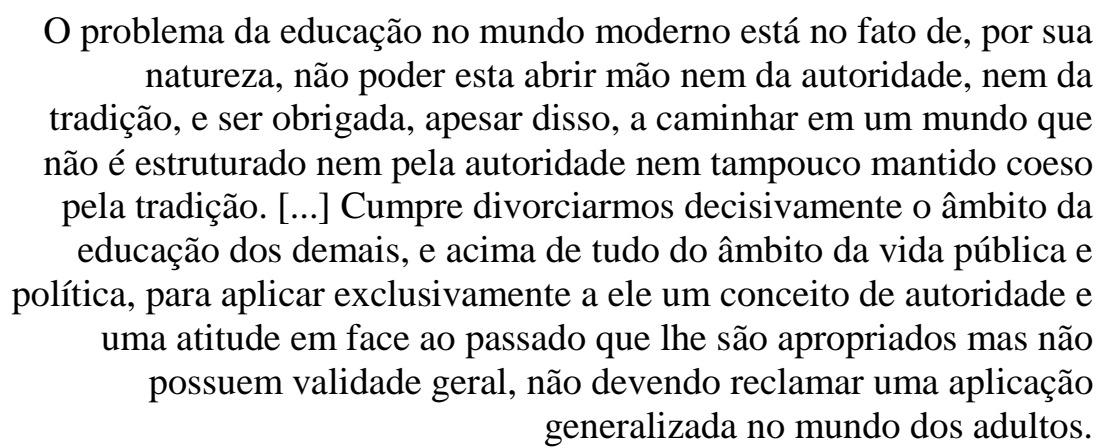

(ARENDT, 1992, p. 245-6)

\subsection{A educação como instrumento da política}

A máxima de que toda pedagogia é política e toda política é pedagógica, associada ao pensamento do educador Paulo Freire, é reveladora de uma concepção programática tanto da política quanto da educação que, no limite, anula as possíveis e desejáveis distinções entre ambas. No entanto, se não é possível negligenciar as relações entre educação e política ainda mais num tempo em que a educação se tornou um desafio político de primeira ordem -, pode ser oportuno recuperar o sentido dessa distinção de forma a evitar que uma seja tragada pela outra. Em 1953, na réplica à resenha que Eric Voegelin fez de Origens do totalitarismo, Arendt (2008b, p. 423) já sublinhava:

[...] minha principal crítica ao atual estado das ciências políticas e históricas se refere à sua crescente incapacidade de fazer distinções. [...] O resultado é uma generalização em que as próprias palavras perdem qualquer significado [...] em que tudo o que há de distinto desaparece.

Seu esforço analítico para estabelecer distinções não implica uma cisão estanque, mas pressupõe relacionar o que se distinguiu. ${ }^{115}$ Nesse sentido, por mais problemático que seja estabelecer o limite entre educação e política, seria equívoco instaurar um corte radical entre os dois âmbitos, pois significaria negar que todo limite, toda fronteira, a um só tempo une e separa. Assim, embora Arendt acentue a distinção entre educação e política, também sugere a impossibilidade de pensar a ação educativa sem referência ao âmbito político: "essas distinções, embora de forma nenhuma arbitrárias, dificilmente correspondem a

\footnotetext{
${ }^{115}$ A respeito das distinções na obra de Hannah Arendt, ver DUARTE, 2013.
} 
compartimentos estanques no mundo real, do qual, entretanto, são extraídas" (ARENDT, 2009, p. 63).

Para introduzir o problema das distinções, ou de sua ausência, vale o depoimento de uma professora de História, Martha Abreu, aqui tomada como um exemplo de uma forma de se relacionar política e educação:

Como quase todos os historiadores, escolhi a profissão porque pretendia mudar o mundo através do ensino de História. "Conhecer o passado para entender o presente e mudar o futuro" foi o lema de muitas gerações de historiadores, inclusive da minha, que viveu a abertura política no final da década de 1970. Acompanhamos intensamente a volta dos exilados, o surgimento dos movimentos sociais de bairros e favelas, a fundação do PT, a eleição do Brizola e o projeto de educação popular de Darcy Ribeiro. Abriam-se muitos campos de atuação para mudar o mundo. Eu escolhi o caminho da educação popular (ABREU, 2009, p. 98, grifos nossos).

Mudar o mundo por meio de ações educativas é uma tarefa no mínimo questionável. Ao ator, sublinha Arendt (1992, p. 91), “o máximo que ele pode ser capaz de fazer é forçar as coisas em uma certa direção, e mesmo disso, jamais pode estar seguro". De qualquer forma, pretende-se questionar a ideia de que a tarefa de um educador consistiria em "mudar o mundo através do ensino", embora esse possa ser um desejo frequente entre educadores, em algum instante ou ao longo de sua vida profissional. Já o questionamento advém de reflexões suscitadas pela leitura do ensaio de Arendt sobre educação.

Publicado primeiramente no periódico Partisan Review (1958), o ensaio A crise na educação foi integrado à coletânea Between past and future: six exercises in political thought, de 1961. Essa obra, com o título Entre o passado e o futuro, foi a primeira de Hannah Arendt publicada no Brasil, em 1972, por iniciativa de Celso Lafer, que se encarregou de apresentála. ${ }^{116} \mathrm{O}$ ensaio figura como uma espécie de filho único no conjunto de textos arendtianos, pois ainda que o tema da educação apareça de forma dispersa em outros de seus escritos, só ali é alçado ao foco da análise. ${ }^{117}$

\footnotetext{
${ }^{116} \mathrm{Na}$ interpretação de Lafer (1992, p. 9), que fora aluno de Arendt na Universidade de Cornell (1965), os leitores encontram no livro, "ainda que de forma um tanto dispersa, todo o temário de sua obra, constituindo-se, portanto, num excelente ponto de partida para uma tentativa de interpretação e organização de seu pensamento".

117 O ensaio A crise na educação, de 1958, foi na verdade concebido como um desdobramento do ensaio Reflexões sobre Little Rock, cuja questão central - e que gerou imensa controvérsia antes mesmo de ser publicado na Dissent, em 1959 - relacionava-se ao problema da integração racial nas escolas americanas. Naquela altura, por força de uma medida da Suprema Corte, a dessegregação - leia-se, a integração forçada - foi imposta às escolas públicas e Arendt se posicionou contrária à medida. Sua tese fundamental, pouco compreendida na época por não explicitar aos leitores a moldura mais ampla em que percebia o fenômeno político da integração, está relacionada ao problema da autoridade e da responsabilidade dos adultos perante o mundo e as crianças. A integração forçada parecia a Arendt um claro exemplo da renúncia dos adultos em face de um problema que se viam incapazes de resolver e que acabaram jogando no colo das crianças: "Chegamos ao
} 
A compreensão que se teve do ensaio, iluminada pelo conjunto da obra de Arendt, sugere que a educação não pode pretender dizer como deve ser o mundo futuro, nem ditar o que deve ser feito para transformá-lo, mas conhecer e compreender como o mundo é. Ressalte-se que a autora não pretende banir a ideia de que o mundo possa ser transformado: nada estaria mais distante de suas reflexões políticas, pois, para Arendt (1992, p. 242), o conservadorismo em política,

[...] aceitando o mundo como ele é, procurando somente preservar o status quo [...], não pode senão levar à destruição, visto que o mundo, tanto no todo como em parte, é irrevogavelmente fadado à ruína do tempo, a menos que existam seres humanos determinados a intervir, alterar, a criar aquilo que é novo.

Daí ela afirmar que o novo sempre assume a feição de um milagre ${ }^{118}$ - um evento que rompe com as expectativas de continuidade e reprodução -, pois sempre se pode contar com o inesperado e o improvável das ações humanas, "porque cada homem é único, de sorte que, a cada nascimento, vem ao mundo algo singularmente novo" (ARENDT, 2010a, p. 222-3). Ocorre que, para Arendt, a renovação de um mundo comum por meio da ação é tarefa a ser cumprida no âmbito da política, e não no da relação pedagógica entre professores e alunos numa instituição escolar. Se para Martha Abreu "abriam-se muitos campos de atuação para mudar o mundo", o âmbito adequado para levar a cabo tal transformação, na perspectiva de Arendt, é o da política, da ação entre iguais no espaço público. Apesar da evidente dimensão política que a educação assume no mundo moderno, Arendt sugere, na contramão das pedagogias ${ }^{119}$ surgidas, uma nítida distinção entre educação e política, num esforço original de distinguir para relacionar e compreender esses dois âmbitos das relações humanas.

\subsection{Fundando uma nova ordem}

A ideia de fundar um mundo novo a partir da educação é uma utopia tão antiga quanto aquela encontrada nas páginas de A República, de Platão. Um exemplo moderno dessa utopia se encontra em Emílio, de Rousseau. Para Arendt (1992, p. 225), essa utopia não apenas

ponto em que se solicita às crianças que mudem e melhorem o mundo? E pretendemos ter as nossas batalhas políticas travadas nos pátios das escolas?" (ARENDT, 2004b, p. 261).

118 “[...] o novo sempre aparece na forma de um milagre. O fato de o homem ser capaz de agir significa que se pode esperar dele o inesperado, que ele é capaz de realizar o infinitamente improvável. E isso, mais uma vez, só é possível porque cada homem é único, de sorte que, a cada nascimento, vem ao mundo algo singularmente novo" (ARENDT, 2010a, p. 222-3).

119 Sobre a crítica de Arendt às chamadas pedagogias progressistas, ver CUSTÓDIO, 2011. 
encontrou expressão conceitual e política nos escritos de Rousseau, como dela se derivou a ideia generalizada e amplamente aceita de que "a educação tornou-se um instrumento da política, e a própria atividade política foi concebida como uma forma de educação".

A desconfiança de Platão e Rousseau com a política - dadas a imprevisibilidade, a irreversibilidade e a fragilidade das ações ${ }^{120}$ - levou-os a pôr a educação a serviço de um ideal político, supostamente realizável por meio da educação de um homem novo, pois "parece natural iniciar um novo mundo com aqueles que são por nascimento e por natureza novos" (ARENDT, 1992, p. 225). Assim formulado o problema, a pergunta acerca do sentido da educação (e, por extensão, do sentido formativo da História) é obscurecida, pois, antes que o pensamento se ocupe dela, a resposta já surge: resguardadas as diferenças entre os dois pensadores, a tarefa de educar se transforma na de forjar um homem novo para uma nova sociedade. ${ }^{121}$ Antes de se questionar sobre a possibilidade disso, seria o caso de perguntar se é algo desejável ou não.

Como toda utopia, o que quer que nela se realize deve habitar o futuro. ${ }^{122}$ É por essa razão que Arendt (2001, p. 33), em Sobre a revolução, de 1963, sugere que o próprio conceito de revolução como algo inteiramente novo não existia antes das duas grandes revoluções ${ }^{123}$ do fim do século XVIII, a francesa e a americana: “Que as revoluções estavam prestes a entrar numa era inteiramente nova tinha já sido anteriormente afirmado pela instituição do calendário revolucionário, onde o ano de execução do rei e da proclamação da república foi contado como o ano primeiro".

Enfim, as ideias de futuro, de novo e de mudança há muito se associam à esfera da educação e a força dessa trindade enraíza-se na crença transformadora da educação para a

\footnotetext{
${ }^{120}$ Jacques Taminiaux rebate os críticos de Arendt que a acusam de uma suposta grecomania, de que em sua obra haveria uma espécie de apologia à performatividade da ação. Reconhece que Arendt vê a ação como uma performance, mas destaca que essa performance - a revelação do quem do agente - é acompanhada, em contrapartida, pelos infortúnios da ação: imprevisibilidade, ilimitabilidade, irreversibilidade, intangilibilidade, fragilidade, futilidade etc. (Cf. TAMINIAUX, 2008, p. 88).

${ }_{121} \mathrm{Na}$ mesma chave, poderíamos lembrar ainda do Poema pedagógico, de Makarenko, que, como sublinhou Belinky (In: MAKARENKO, 2005), "com material tirado da própria vida [...] desvendou o problema da reeducação socialista, do nascimento do "homem novo"”.

${ }^{122}$ A esse respeito, vale lembrar que, no liceu napoleônico (a escola nascida com a Revolução Francesa), a origem de um aluno - ou, antes, de seu passado - não contava, assim como a origem do jovem que chegava à Colônia Gorki, na então União Soviética, onde Makarenko desenvolveu suas experiências educacionais nos anos 1920 (Cf. PRESTES, 2005, p. 646).

${ }^{123}$ Carlota Boto (1996, p. 176) sublinha que, para os revolucionários franceses que tomaram para si a tarefa de forjar a educação, "se tratava de uma história em que o futuro já era quase passado, na medida em que, descartados o acaso e a indeterminação inscritos no tempo, acreditava-se numa rota já profetizada - quase uma fatalidade - cuja imanência deveria ser apenas revelada".
} 
construção de um futuro político promissor. ${ }^{124}$ No caso da educação brasileira, desde o Manifesto dos Pioneiros da Educação Nova, de 1932, o discurso dominante exorta os profissionais a educar sob a égide do novo. Tudo se passa como se os educadores já habitassem a nova escola, que deve dar guarida ao novo professor, que está de posse de uma nova pedagogia, que tem como alvo um novo aluno e assim por diante.

Em Falas do novo, figuras da tradição, Cordeiro (2002) revela como o discurso pedagógico dos anos 1970 e 1980 foi profundamente marcado pela ideia do novo, da mudança, e como naqueles anos se combateu fortemente um suposto ensino tradicional suposto porque carente de uma descrição sistemática - ao qual se atribuíram as mazelas da educação no país. O estudo evidencia como o vocabulário de combate então utilizado pelos renovadores fora derivado de âmbitos distintos da educação, não raro tendo origem na esfera política (quando não na político-partidária), e frequentemente marcado por palavras de ordem e slogans presentes originalmente não no campo das chamadas ciências da educação, mas nos movimentos sociais e nas lutas políticas que então se travavam em prol da redemocratização do país. ${ }^{125}$

Se não se pode nem se deve negligenciar a potencial dimensão política da educação como introdução dos recém-chegados no mundo, isso não equivale a fazer da educação, parafraseando a máxima de Clausewitz, uma continuação da política por outros meios. Assim, ao escolher a escola como palco da mudança político-social, Martha Abreu talvez não percebesse que, em vez de ensinar, fazia da sala de aula um simulacro da vida política. Em posição totalmente contrária a esse preceito, Arendt (1992, p. 226) considera que pertence

[...] à própria natureza da condição humana o fato de que cada geração se transforme em um mundo antigo, de tal modo que preparar uma nova geração para um mundo novo só pode significar o desejo de arrancar das mãos dos recém-chegados sua própria oportunidade face ao novo.

Diante disso, o que significa para ela "preparar uma nova geração para um mundo novo"? Como é possível ao educador não usurpar "dos recém-chegados sua própria oportunidade face ao novo"?

\footnotetext{
${ }^{124}$ Em contraste com essa crença no poder transformador da educação, poderíamos lembrar o pessimismo e mesmo a angústia (COHN, 1986, p. 17) de um autor como T. W. Adorno quando reflete sobre os limites de um trabalho educativo. A esse respeito, ver os textos Educação após Auschwitz e Educação e emancipação, em que Adorno (2000) coloca sob forte suspeição a ideia de que a educação poderia emancipar o homem no sentido kantiano de emancipação.

${ }^{125} \mathrm{O}$ trabalho de Cordeiro (2002) deixou pistas instigantes que foram exploradas na dissertação de mestrado intitulada Quando a teoria inventa a prática: os discursos de "renovação" frente ao ensino "tradicional" de História (AUGUSTO, 2003).
} 


\subsection{Acolher os novos e dizer: isto é o mundo}

Como pode perceber qualquer pessoa que convive com crianças, para elas a novidade do mundo brota como mágica diariamente, pois, recém-chegadas que são, tudo lhes parece admiravelmente novo. Mas isso só é verdadeiro, sublinha Arendt (1992, p. 226), para aqueles que são novos no mundo, não para o mundo: "O mundo no qual são introduzidas as crianças [...] é um mundo velho, isto é, um mundo pré-existente, construído pelos vivos e pelos mortos". Ela recorda que toda nota de dólar traz impressa o lema Novus Ordo Seclorum (uma nova ordem no mundo) e que o significado de Novo Mundo - num país constituído por imigrantes como os Estados Unidos - retira sua força da expressão Velho Mundo:

O papel político que a educação efetivamente representa em uma terra de imigrantes, o fato de que as escolas não apenas servem para americanizar as crianças mas afetam também a seus pais, e de que aqui as pessoas são de fato ajudadas a se desfazerem de um mundo antigo e a entrar em um novo mundo, tudo isso encoraja a ilusão de que um mundo novo está sendo construído mediante a educação das crianças (ARENDT, 1992, p. 226).

Ingressar nesse novo mundo no qual aportam os imigrantes (pais e filhos) significa tomar parte de um ethos social e simbólico da cultura americana que glorifica o novo. A igualdade de oportunidades é um dos princípios professados como parte desse ethos e que o acesso público à escolarização materializa. Para Arendt, a crise da educação norte-americana não se deve a um suposto atraso em relação aos padrões europeus de ensino, tampouco ao fato de os Estados Unidos serem um país jovem. A crise na educação tem estreita relação com a crise política que acometeu o mundo moderno a partir das experiências totalitárias numa sociedade de massas e que resvalou para âmbitos que Arendt considera pré-políticos, ${ }^{126}$ como a família e a educação. Enquanto esfera pré-política, a educação "está para a novidade assim como, no domínio político, a fundação está para a ação: no interstício entre a conservação e a renovação, entre o zelo e a transformação" (CORREIA, 2010b, p. 819).

De acordo com Arendt, as pretensas soluções encontradas pelos educadores americanos para promover uma educação de massas com vistas a igualar oportunidades acabaram mesclando o pathos do novo e modernas teorias educacionais europeias sob a divisa da progressive education deweyana. Arendt (1992, p. 228) conclui que a crise da educação

\footnotetext{
${ }^{126}$ Cabe ressaltar uma das dimensões que Arendt confere ao âmbito pré-político da educação, que é o da assimetria, ainda que temporária, da relação entre professores e alunos, em contraste com a isonomia que funda a relação política entre cidadãos. Sobre a distinção entre político e pré-político no âmbito da educação, ver BENVENUTI, 2010.
} 
americana "apresenta um problema imensamente difícil por ter surgido sob as condições de uma sociedade de massas e em resposta às suas exigências". Em outras palavras, a crise que acometeu a educação não tem um significado restrito à sociedade americana. Se é a crise dos desafios de uma educação de massas, pode acometer todo e qualquer país que tenha escolhido como desafio político universalizar a educação.

Arendt (1992, p. 242) formulou uma concepção original do processo educativo cujo traço é a natureza conservadora que atribui à educação:

[...] parece-me que o conservadorismo, no sentido de conservação, faz parte da essência da atividade educacional, cuja tarefa é sempre abrigar e proteger alguma coisa - a criança contra o mundo, o mundo contra a criança, o novo contra o velho, o velho contra o novo. Mesmo a responsabilidade ampla pelo mundo que é aí assumida implica, é claro, uma atitude conservadora. Mas isso permanece válido apenas no âmbito da educação, ou melhor, nas relações entre adultos e crianças, e não no âmbito da política, onde agimos em meio a adultos e com iguais.

Assim, um educador que pretenda "mudar o mundo através do ensino" pode incorrer no equívoco de, em vez de preservar a novidade em potencial que habita cada novo ser - no caso, seus alunos -, inventar ele próprio essa novidade, usurpando dos alunos a possibilidade de empreendê-la por si mesmos, se assim o desejarem. Na perspectiva de Arendt (1992, p. 243, grifo nosso),

[...] exatamente em benefício daquilo que é novo e revolucionário em cada criança é que a educação precisa ser conservadora; ela deve preservar essa novidade e introduzi-la como algo novo em um mundo velho, que, por mais revolucionário que possa ser em suas ações, é sempre, do ponto de vista da geração seguinte, obsoleto e rente à destruição.

Portanto, Arendt insiste em preservar um limite entre política e educação inclusive por acreditar que a própria possibilidade da renovação de um mundo comum implica uma atitude conservadora em educação. Por trás dessa atitude (que é política por excelência) está o cuidado com o mundo e o zelo em relação à promessa da novidade que advém em cada nascimento. Ao mundo, que é a morada dos recém-chegados e será o palco de sua ação política, a atitude conservadora confere durabilidade e proteção. À promessa contida no nascimento, ela conserva a potencialidade da futura ação espontânea e criativa. Da mesma forma, o limite entre educação e política está intimamente relacionado ao fato de que o ingresso na vida política representa um novo nascimento do sujeito, agora livre da autoridade, seja da família, seja da instituição escolar. A esse respeito, Bárcena (2006, p. 225, grifo nosso) sublinha que o educador não deve 
[...] aspirar a crear un mundo nuevo con seres nuevos. Ésta es una tentación totalitaria. Mas bien, representa un mundo más antiguo, en cierto modo inmemorial, un mundo que es tiempo y que se transmite creativamente para que la pregunta por el sentido no quede cancelada. ${ }^{127}$

Se o educador não deve aspirar à criação de um mundo novo a partir daqueles que são novos no mundo, isso vai ao encontro da compreensão de Arendt de que o agir, a ação política, também não significa fabricar uma nova sociedade. Assim, a educação não deve ser compreendida como fabricação de um homem novo, tampouco de um novo mundo. Sua visão, justamente por contrariar o que de ordinário se postula como tarefa da educação e da política, não se evidencia de imediato.

Há, entretanto, uma dimensão fundamental no argumento de Arendt que não se pode negligenciar. Sem o dizer explicitamente, ela põe em relevo um aspecto que tanto em política quanto em educação se vê cada vez mais recusado: trata-se de acolher a ideia de que a existência de projetos políticos e educacionais comporta também uma indeterminação. Arendt (1992, p. 92, tradução modificada) é taxativa quando diz que imprevisibilidade não significa falta de previsão: "Unicamente o total condicionamento, vale dizer, a total abolição da ação, pode almejar algum dia fazer face à imprevisibilidade".

No entanto, tudo se passa como se no âmbito da política e da educação bastasse um bom plano feito por especialistas, assim como a existência de gestores competentes que se põem a executá-lo a fim de se criarem as condições para um mundo planejado de antemão. Sem negar a importância do saber de um especialista, a desmedida ênfase com que os problemas são resumidos a uma solução técnica só aponta para um crescente declínio e esvanecimento da política. Tanto o âmbito político quanto o âmbito educacional se veem constantemente tentados a buscar soluções que reduzem ao mínimo a espontaneidade da ação, procurando abrigar-se na segurança dos meios com vistas aos fins pretendidos, isto é, à imagem da fabricação.

Assim, convém retomar a interpretação de Arendt sobre a filosofia política de Platão (agora com a introdução da figura de Sócrates) para que se possa, adiante, remetê-la ao âmbito da educação.

\footnotetext{
${ }^{127} \mathrm{Na}$ mesma linha argumentativa Duarte (2007, p. 85) observa que Arendt "é crítica em relação a projetos educacionais que politizam a educação, considerando-os autoritários e mesmo contraditórios, já que toda tentativa de produzir o novo impede na realidade a sua aparição".
} 


\subsubsection{A dignidade da ação política}

A emergência do totalitarismo significou uma dupla falência: a do pensamento político ocidental e a da própria atividade política, na medida em que esta perdera sua dignidade ${ }^{128}$ no rol das atividades humanas. Arendt insiste, entretanto, que a tradição não é todo o passado. Assim, como toda tradição é seletiva, ela resgata experiências políticas que não mereceram registro. Como sublinha Drucker (2000, p. 205), "aquelas possibilidades positivas que ficaram apenas insinuadas na história [e que] podem ser redescobertas e apropriadas", pois poderia "ocorrer que somente agora o passado se abrisse a nós com inesperada novidade e nos dissesse coisas que ninguém teve ainda ouvidos para ouvir" (ARENDT, 1992, p. 130).

Como uma reflexão nascida da crise que acometeu o mundo moderno, a análise histórico-política de Arendt parte dos acontecimentos e a eles permanece vinculada, pois lançam luz sobre a compreensão do passado. ${ }^{129}$ Mas assinala que uma crise põe a descoberto problemas que só se revelam com sua emergência, podendo libertar preconceitos que não oferecem mais resposta a questões ou até mesmo acirrá-los. Seja como for, o aspecto importante de uma crise na educação é a oportunidade por ela oferecida à reflexão. Assim, ela não é, por princípio, danosa: "só se torna um desastre quando respondemos a ela com juízos pré-formados" (ARENDT, 1992, p. 223). Ora, a crise que acomete a educação e a indistinção cada vez mais acentuada entre os âmbitos da política e da educação é um convite a refletir, seja sobre o sentido da educação, seja sobre o significado do passado, isto é, da história.

Arendt olha o passado visando a identificar experiências políticas singulares, ignoradas pela tradição, mas capazes de iluminar o presente, tal como a experiência da Atenas pré-platônica. Ela nutre uma forte suspeita de que a compreensão platônica da política fora realizada olvidando a experiência real pela qual os atenienses viviam a política do dia a dia. Nesse sentido, o empreendimento de Arendt (1992, p. 44) se assemelha a uma tentativa de fazer um inventário histórico sobre o esquecimento da política: "A filosofia política implica necessariamente a atitude do filósofo para com a política; sua tradição iniciou-se com o abandono da política por parte do filósofo, [no caso, Platão] e o subsequente retorno deste para impor seus padrões aos assuntos humanos".

\footnotetext{
128 Duarte (2000, p. 168, grifo nosso) sublinha que "A ousadia e a radicalidade do pensamento arendtiano, o traço que lhe confere distinção em relação a toda a tradição do pensamento político ocidental, revela-se justamente em seu objetivo de recuperar a dignidade da atividade política".

129 Num ensaio sobre o conceito de crise em Hannah Arendt, Porcel (2013, p. 202) sublinha a valiosa contribuição de Kosseleck de que, em suas origens gregas, o termo crítica tinha a mesma raiz que crise (krinein), isto é, de que a crítica é o caminho que devemos tomar para iniciar a transformação da crise.
} 
O “abandono da política por parte do filósofo" está estreitamente ligado, para Arendt, ao julgamento e à morte de Sócrates, experiência que ela resgata a partir da análise que faz de Apologia, Teeteto e Menon, de Platão. ${ }^{130}$ Nesse resgate, surge um Sócrates que se defende publicamente diante de seus acusadores e concidadãos, reafirmando sua importância e seu interesse para a vida política da cidade. A condenação de Sócrates pelos atenienses faria com que Platão, seu discípulo, passasse a desconfiar da persuasão, qualidade retórica fundamental para a vida da polis, onde por atos e palavras os cidadãos livres agiam no interesse comum em razão de um mundo comum. Desconfiar da capacidade humana de ação política não seria o mesmo que retirar toda a dignidade da ação quando ela emerge entre os homens? E não foi em nome dessa mesma dignidade da qual atos e palavras se revestem que Platão, indignado, viu ser condenado à morte aquele a quem tanto admirava? ${ }^{131}$

A análise que Arendt empreende da parábola da caverna, no livro VII de A República, de Platão, revela como a desconfiança inicial acabou se convertendo em pura hostilidade da filosofia para com a política. Daí em diante, um fosso se abria entre os homens de ação e os homens de pensamento. A filosofia cedera à tentação de "impor seus padrões aos assuntos humanos", derivando do campo das ideias a forma pela qual as ações políticas deveriam ocorrer.

Na interpretação da parábola surge o personagem Sócrates, sua vida dedicada à polis, seu julgamento e sua morte. A experiência política vivida por Sócrates em Atenas não autoriza, pensa Arendt, que se cristalize na tradição a separação entre ação e pensamento, conforme estabelece o legado platônico. Ao contrário, em Sócrates, ação e pensamento são atividades que caminham juntas, donde a máxima socrática "Só sei que nada sei” ser um forte testemunho de que o filósofo nunca pretendeu ensinar nada a ninguém, tampouco impor a outrem sua opinião (doxa), mas, ao contrário, conhecendo outras opiniões (doxai), procurava

\footnotetext{
${ }^{130}$ No ensaio Arendt y Sócrates, Villa (2008, p. 119-120) sublinha três aspectos do Sócrates arendtiano. O primeiro, resgatado em Apologia, refere-se ao Sócrates que pretendia evitar que "os cidadãos de Atenas vivessem adormecidos pelo resto de seus dias e atuassem sem uma autêntica reflexão moral". O segundo, resgatado em Teeteto, "é o Sócrates 'parteiro', que desfaz os preconceitos e evidências de seus interlocutores ajudando-os a conhecer seus próprios pensamentos". Por fim, o terceiro Sócrates, resgatado em Menon, "é o Sócrates 'torpedo', espécie de peixe [arraia] elétrico que paralisa e emudece a todos aqueles que lhe tocam". Cabe ressaltar que Villa não compartilha da forma como Arendt se apropria do Sócrates platônico.

131 Numa carta a Jaspers de $1^{\circ}$ de julho de 1956, Arendt (2010b, p. 138) revela que "Desde el proceso de Sócrates, es decir, desde que la polis procesó al filósofo, hay un conflicto entre política y filosofía que yo intento rastrear".
} 
alargar o quanto possível a compreensão do mundo, quer para si, quer para seus interlocutores. $^{132}$

Ao recusar a oferta do exílio ou o pagamento de uma multa para se livrar da condenação à morte, Sócrates legou, na interpretação de Arendt, não apenas um exemplo de retidão moral, mas a compreensão de que o sentido da política se volta para o cuidado com a polis, isto é, de que ela é um fim em si mesma. Assim, se escolhermos viver tendo Sócrates por companhia, tornamo-nos capazes de escolher aquilo que não devemos fazer, mas não o que fazer. E isso certamente está por trás do grande interesse de Arendt pela figura de Sócrates quanto ao tema do totalitarismo. Ela nutria profunda admiração por aqueles que foram capazes de dizer "Não, isso eu não posso fazer", diferentemente de Eichmann, por exemplo, incapaz de pensar o significado da deportação de milhões de pessoas para as fábricas de extermínio.

Surpreendentemente, a filosofia política de Platão, toda ela construída na forma de diálogos, nutre um não disfarçado temor de que o diálogo entre os cidadãos constitua a forma pela qual os homens se relacionam politicamente - isto é, que juntos, animados por princípios, opinem e decidam o que é de interesse comum. Por isso pretende simplesmente abolir o diálogo por meio do governo do rei-filósofo, aquele que sabe:

As idéias tornaram-se padrões de medida somente depois que o filósofo deixou o céu límpido das idéias e retornou à escura caverna da existência humana. [...] ele [o filósofo] nos fala da perda de orientação [...] da cegueira que atinge seus olhos, da angustiosa situação de não ser capaz de comunicar o que viu e do verdadeiro perigo para sua vida que daí surge. É nesse transe que o filósofo apela para o que ele viu, as idéias, como padrões e normas e, finalmente, temendo por sua vida, as utiliza como instrumentos de dominação (ARENDT, 1992, p. 149).

Uma vez que contemplou o "céu límpido das idéias", especialmente a suma ideia do bem, o agora artífice da boa política (um perito) substituirá a ação (práxis) - em que liberdade, pluralidade e espontaneidade habitam - pela fabricação (poiésis). Conhecendo a ideia (eidos) do bem, poderá o rei-filósofo moldar a cidade conforme o padrão e a norma que pode contemplar, ainda que essa operação se dê ao custo de abolir a liberdade das ações e a pluralidade característica de todo espaço genuinamente público. Como toda liberdade implicada na ação comporta uma ilimitada imprevisibilidade, é contra essa insegurança ante os efeitos da ação que o filósofo pretenderá edificar sua cidade. A ação (práxis) passa a ser

\footnotetext{
${ }^{132}$ Não é gratuito o fato de que os primeiros diálogos de Platão - os mais próximos, portanto, da morte de Sócrates - acabem sem solução (aporia), quando não num mútuo convite para que os interlocutores voltem outro dia a debater o assunto em questão.
} 
concebida como fabricação (poiésis), com vistas a abolir a imprevisibilidade do resultado das ações políticas. ${ }^{133}$

A política concebida a partir da fabricação (poiésis) sugere uma correspondência com as artes e com os ofícios, o que pressupõe um saber especializado - no caso, o do estadista. Analogamente, como todo objeto fabricado, a política deixa de ter um sentido e passa a ser um instrumento, um meio para a consecução de algum fim outro que não ela própria.

Da mesma forma, se a violência é um dado inerente à fabricação - porque não se pode fabricar um objeto sem violentar de alguma forma a natureza -, derivou-se a noção de que a violência é inerente à política, o que Arendt contesta ao longo de sua obra. Esse legado platônico sobre a política seguiu praticamente inalterado até Marx, que retoma essa tradição, mas também assinala seu fim, quando pretende realizar a própria filosofia na política, ou seja, fazer história.

O que justifica esta digressão é justamente a suspeita de que as relações entre educação e política ainda estejam profundamente marcadas por uma compreensão da política como fabricação. A hipótese que aqui se levanta é a de que esse modo de compreensão da política como meio para a consecução de fins a ela extrínsecos foi transposto para aquela que, seguramente, é a disciplina escolar mais permeável à compreensão ou à ação política: a História. Assim, o ensino de História deixa de ser animado por um princípio que busca pelo sentido e passa a servir a uma finalidade, passando a ser concebido como apenas um meio para a realização de fins estranhos a ele, entre os quais aqui importa destacar a tentativa de fabricar o futuro.

Com isso não se pretende afirmar que a educação em geral e o ensino de História em particular não se relacionem, em alguma medida, com aquilo que está por vir; tampouco que seja possível educar sem o estabelecimento de um currículo, de metas e objetivos a se alcançar. Conforme destaca Manuel Cruz (1999, p. 46): “Las generaciones que nos seguirán son la única superficie sobre la que podemos escribir el futuro. El hombre nuevo, si tal expectativa todavía conserva alguna virtualidad, no se construye ni se produce: se deja que sea”. Ora, parece não haver dúvida de que essa expectativa não só se conserva, como é indissociável do âmbito da educação. Entretanto, como sublinha Cruz, isso não significa que se vá escrever o futuro fabricando o homem novo.

${ }^{133}$ A esse respeito, Duarte (2000, p. 194-5) sublinha: "Para que as idéias pudessem ser aplicadas ao mundo da política, era preciso que a própria atividade política fosse concebida segundo os moldes da fabricação, atividade na qual a distinção entre 'saber e executar' constitui um desdobramento natural, pois só se podem organizar os meios e passar à execução de algo uma vez que se tenha percebido anteriormente a imagem ou forma (eidos) do produto que se vai fabricar". 
A esse respeito, Lefort observa que todo ideal de educação - o sentido com o qual ela está investida - guarda íntima relação com o ideal de homem que determinada sociedade forja para si mesma. Espantado com a recusa de certo ideal humanista de educação na França em fins dos anos 1970, o autor retomava a experiência da Florença renascentista ${ }^{134}$ no que se refere ao cultivo de uma cultura geral. Para ele, esse princípio, que significa uma ruptura com a escola latina medieval, implica que

[...] a educação não possui mais limites definidos [...]. Em certo sentido, ela acolhe a indeterminação, já que quem aprende está sendo requisitado, não tanto para dominar um certo lote de conhecimentos, mas sim para travar um novo relacionamento com o saber (LEFORT, 1999, p. 211).

Antes de pretender restaurar um modelo humanista de educação, o gesto de Lefort tem em comum com a análise de Arendt (1992, p. 223) o fato de que uma crise na educação "nos obriga a voltar às questões mesmas e exige respostas novas ou velhas, mas de qualquer modo julgamentos diretos". Ora, a dimensão política da educação se revela tanto em relação ao passado, quanto em relação ao presente e ao futuro, ainda que de formas distintas, como se verá adiante. Nunca é demais recordar que o ensaio A crise na educação está inserido na obra Entre o passado e o futuro, cujo subtítulo diz: seis exercícios de pensamento político. Portanto, as distinções e relações entre educação e política que Arendt propõe no ensaio estão longe de recusar um sentido político para a educação, ainda que a questão tenha levado a inúmeras controvérsias entre seus intérpretes.

Nada diz mais respeito ao futuro (tanto da política quanto da educação) do que o conceito que Arendt (1992, p. 223) aponta como sendo a essência ${ }^{135}$ da educação: a natalidade, "o fato de que seres nascem para o mundo", isto é, de que o mundo é renovado diuturnamente por meio do nascimento. O infanticídio que Heródes encarna é um testemunho da tentativa de controlar o futuro eliminando a novidade que surgiu no mundo com o nascimento de Jesus em Belém. ${ }^{136}$ Do mesmo modo, nenhum outro conceito arendtiano aponta melhor a essência da política do que a pluralidade, sendo que a natalidade estabelece a

\footnotetext{
134 "Antes de mais nada, cabe lembrar que os humanistas, ao se dedicarem aos seus estudos, pretendiam formar um novo homem, distante daquele que servira de modelo para os autores cristãos dos séculos anteriores. Se hoje estamos em condição de medir os limites e o alcance dessa proposta, não podemos deixar de observar que o simples fato de propor a formação de um homem à distância dos modelos conhecidos do homem cristão, dedicado à contemplação em sua forma mais perfeita, já era por si mesmo uma revolução, independente das dificuldades e mesmo das continuidades que podiam estar escondidas no processo de formação" (BIGNOTTO, 2001b, p. 152-3).

${ }^{135} \mathrm{O}$ emprego do termo essência por parte de Arendt não tem nenhuma conotação metafísica, como uma essência apartada do mundo das aparências e hierarquicamente superior, mas remete ao sentido compartilhado (intersubjetivo).

${ }^{136}$ Cf. LARROSA, 2010, p. 190.
} 
necessária ponte entre os dois âmbitos, uma vez que as ações políticas não apenas têm o dom de iniciar algo novo e inusitado no mundo, mas também representam a revelação daquela singularidade que veio ao mundo com o nascimento de um alguém. Não é à toa que, no ensaio Ideologia e terror, mais tarde incorporado a Origens do totalitarismo, Arendt (1989, p. 518) declara:

Do ponto de vista totalitário, o fato de que os homens nascem e morrem não pode ser senão um modo aborrecido de interferir com forças superiores. $\mathrm{O}$ terror, portanto, como servo obediente do movimento natural ou histórico, tem de eliminar do processo não apenas a liberdade em todo sentido específico, mas a própria fonte de liberdade que está no nascimento do homem e na sua capacidade de começar de novo.

Daí a dignidade e a responsabilidade da qual se reveste a educação, uma vez que ela é um âmbito que não apenas acolhe um recém-chegado, isto é, uma singularidade, como retém num longo processo de formação a promessa desse novo alguém. O perigo - e talvez aí resida a força da distinção arendtiana entre educação e política - está na pretensão, quando não na intenção declarada, de fabricar seja esse alguém, seja o futuro. A negativa de Arendt quanto a essas pretensões, que para ela soariam totalitárias, é de que entre as imprescindíveis tarefas da educação está a de possibilitar àquele recém-chegado o cultivo do amor mundi, ${ }^{137}$ isto é, o desejo de que o mundo perdure. Nas palavras de Arendt (1992, p. 247), a "educação é ponto em que decidimos se amamos o nosso mundo o bastante para assumirmos a responsabilidade por ele e, com tal gesto, salvá-lo da ruína que seria inevitável não fosse a renovação e vinda dos novos e dos jovens".

Ora, aqui se apresenta um novo problema. Como um professor poderá assumir a responsabilidade política por um mundo em que ele próprio não se sente em casa? Em outras palavras, o que Arendt parece sugerir é que qualquer que seja a representação que um professor faça do mundo - e o mundo é constantemente posto fora dos eixos -, é impossível educar sem algum apreço pelo mundo. $\mathrm{O}$ aspecto mais pungente e corajoso do ensaio de Arendt é o fato de que no centro de sua concepção de educação não está a criança, mas o mundo e a aposta que o educador faz por sua continuidade por meio do acolhimento dos novos em seu seio. Na contramão das chamadas pedagogias não diretivas ou da autonomia, que colocam o sujeito no centro da relação de ensino, isto é, a criança e seus interesses, a

\footnotetext{
${ }^{137}$ Essa dimensão da educação é o tema da tese de doutorado de Vanessa S. de Almeida (2009), intitulada Amor mundi e educação: reflexões sobre o pensamento de Hannah Arendt e posteriormente publicada sob o título Educação em Hannah Arendt: entre o mundo deserto e o amor ao mundo (2011).
} 
profissão de fé do educador vislumbrado por Arendt (1992, p. 247) revela seu amor pelas crianças por

[...] não expulsá-las de nosso mundo e abandoná-las a seus próprios recursos, e tampouco arrancar de suas mãos a oportunidade de empreender alguma coisa nova e imprevista para nós, preparando-as em vez disso com antecedência para a tarefa de renovar um mundo comum.

Essa aposta pela continuidade do mundo traz consigo algumas ambiguidades, dado o longo período de formação em que as crianças e os jovens são preparados para "a tarefa de renovar um mundo comum". Ao mesmo tempo em que assume a responsabilidade pelo mundo e pelo ensino de um legado de tradições, o educador protege esse mesmo mundo do assédio que irrompe dos novos. Mas isso não é tudo. O educador que não abre mão de sua autoridade e de sua responsabilidade pelo mundo e pela iniciação dos novos a esse mundo ainda deverá se esforçar por preservar a novidade em potência que habita os novos, evitando o despotismo de inventar por si mesmo essa novidade. Como se vê, as reflexões de Arendt impõem aos educadores um desafio ético e político da mais alta relevância. No entanto, esse desafio comporta problemas que não são autoevidentes e que, por dizerem respeito à dimensão política da educação, implicam uma melhor aproximação ao conceito de natalidade em Arendt.

\subsubsection{A dimensão política da natalidade no âmbito da educação}

Agir, para Arendt (1992, p. 199), é tomar iniciativa, começar algo novo: "Os homens são livres - diferentemente de possuírem o dom da liberdade - enquanto agem, nem antes, nem depois; pois ser livre e agir são uma mesma coisa”. Ela ilustra essa coincidência entre "ser livre e agir" por meio das artes em que a presença dos espectadores é que confere virtuosidade a um desempenho, seja de um músico, de um dançarino ou de um ator. Mas em relação a esse dom essencialmente humano de iniciar algo ou, melhor dizendo, à possibilidade que a ação tem de revelar a singularidade de um alguém, Arendt é devedora de Agostinho, em cuja obra buscou inspiração para pensar o tema da natalidade. Correia (2008, p. 17, grifos nossos) observa que

[...] é pela compreensão do homem como initium e pelos conceitos de amor ao mundo e de natalidade que Agostinho é mais caro a Arendt. Com efeito, Agostinho afirmou, em uma frase que é seguramente a citação mais recorrente na obra publicada de Arendt, que "para que houvesse um início o homem foi criado, sem que antes dele ninguém o fosse". 
Isso sugere que a natalidade não apenas contém a marca de um acontecimento único, irrepetível, mas a promessa da aparição de uma singularidade humana. Politicamente, entretanto, a natalidade é uma potencialidade, uma simples promessa, já que o acesso ao mundo público-político está interditado aos novos por uma espécie de moratória - variável segundo as diferentes culturas -, em razão do tempo implicado no processo de formação de um sujeito. Não deixa de ser notável que o único personagem das narrativas homéricas que se vê entrar na idade adulta seja Telêmaco, o filho de Ulisses e Penélope, e que a marca de seu ingresso - ele teria por volta de 20 anos, "idade que o jovem ateniense da época clássica se tornava membro da assembléia" (VIDAL-NAQUET, 2002, p. 86-7) - seja justamente o restabelecimento da polis (Ítaca) ao se convocar o conselho e a assembleia.

Certamente não é gratuito o fato de que, nas mais variadas culturas, o interdito do acesso ao voto cesse ao tempo final da escolaridade média, impondo-se como fronteira a separar aqueles que, segundo Arendt (1992, p. 160, grifo nosso), ainda não podem ser responsáveis pelo mundo, por estarem num processo de formação, ${ }^{138}$ daqueles cuja responsabilidade pelo mundo não pode ser recusada:

No âmbito político tratamos unicamente com adultos que ultrapassaram a idade da educação propriamente dita, e a política, ou o direito de participar da condução dos negócios públicos, começa precisamente onde termina a educação [...]. Reciprocamente, em educação lidamos sempre com pessoas que não podem ser ainda admitidas na política e na igualdade, por estarem sendo preparadas para elas.

Do que foi dito até aqui, pode-se concluir que a ação política assim concebida não se coaduna com as pretensões de "mudar o mundo através do ensino" por parte de um educador. A atitude conservadora sugerida por Arendt em relação à educação implica que a transformação do mundo seja uma tarefa própria ao âmbito da política. ${ }^{139}$ Assim, um educador que admita fazer de suas aulas um suposto local de ação política visando à transformação do mundo ludibria-se - ainda que com a melhor das intenções e em nome dos mais nobres princípios -, pois, inadvertidamente, realiza de fato uma forma de coerção sobre os alunos, coerção esta ainda pior do que a praticada entre adultos, a qual se dá entre cidadãos

\footnotetext{
${ }^{138}$ Mesmo no caso brasileiro, em que o direito político ao voto pode ser adquirido já aos 16 anos, os constituintes tiveram o cuidado de não o impor, mas de simplesmente o facultar aos jovens, numa clara demonstração de que eles não precisavam - para usar os termos de Arendt - sentirem-se responsáveis pelo mundo.

${ }^{139}$ Essa visão de Arendt não é compartilhada por Maria Rita César (2007, p. 41): "Se o mundo público desejado por Hannah Arendt não existe mais e tampouco os instrumentos que possibilitariam o seu ressurgimento contemporâneo, talvez a política deva ser re-inventada e comunidades escolares poderão ser o novo local dessa reinvenção".
} 
ao menos juridicamente tidos como iguais, o que não é verdadeiro em face da assimetria existente entre professores e alunos no espaço escolar. Para Arendt (1992, p. 238-9), a escola é

[...] a instituição que interpomos entre o domínio privado do lar e o mundo com o fito de fazer com que seja possível a transição, de alguma forma, da família para o mundo. Aqui [na escola], o comparecimento não é exigido pela família, e sim pelo Estado, isto é, o mundo público, e assim, em relação à criança, a escola representa em certo sentido o mundo, embora não seja ainda o mundo de fato.

Representar o mundo sem, contudo, sê-lo propriamente coloca a escola num lugar dúbio, numa espécie de fronteira. Se Arendt não nega essa dubiedade, também não pretende resolvê-la, o que é bem próprio ao seu estilo de querer compreender sem prognosticar. Como boa discípula de Sócrates, ela formula e nos lega um problema da mais alta importância, mas não o resolve. Suas distinções, ainda que iluminadoras, também acabam multiplicando dificuldades. Assim, as ambiguidades entre educação e política em sua obra talvez acabem como os primeiros diálogos platônicos, isto é, intencionalmente sem solução, a fim de que cada geração se debruce novamente sobre as frágeis e por vezes delicadas fronteiras que unem e separam educação e política.

Nessa linha interpretativa, um artigo de Carvalho (1998) sugere, em relação à autoridade, que a escola não é nem deve fingir ser um espaço de igualdade no que se refere à relação entre professores e alunos, pois esta não é análoga à relação entre cidadãos. $\mathrm{O}$ autor reconhece que a autoridade do professor se apoia numa divisão desigual de poderes no interior da relação pedagógica. No entanto, insiste no argumento de que nessa assimetria se fundamentam as escolhas que o mundo adulto fará - em momentos determinados e sempre sujeitas a reformulações quanto ao que deve ser legado às novas gerações - e de que os conteúdos (o currículo escolar) sempre serão passíveis de críticas e reformulações. Entretanto, considera que isso não anula nem subtrai a responsabilidade e a autoridade do professor. Ao contrário, a autoridade

[...] deriva do fato de que ele é o agente institucional que inicia os jovens em uma série de valores, conhecimentos, práticas e saberes que são heranças públicas que uma nação escolheu preservar através de sua apresentação e incorporação por parte daqueles que são novos no mundo. Nesse sentido, somos co-autores dessas tradições e a autoridade deriva, etimológica e eticamente da autoria, nesse caso, dessa co-autoria (CARVALHO, 1998, p. 26). 
Todavia, essa autoridade que legitima a ação educativa e é traduzida na responsabilidade de apresentar os novos ao mundo e para o mundo, isto é, iniciar crianças e jovens num mundo de heranças públicas que os precedem e que os sucederão, vem sofrendo uma severa restrição por parte do discurso pedagógico dominante. Tal restrição assume múltiplas faces. Uma delas está ligada à nossa relação com o passado e que, na avaliação de Tocqueville (apud ARENDT, 1992, p. 32), um homem do século XIX, já era expressa sucinta e densamente com as seguintes palavras: "Desde que o passado deixou de lançar sua luz sobre o futuro, a mente do homem vagueia nas trevas".

Tocqueville não viveu o horror das experiências totalitárias. Depois delas, a relação passado-presente se tornou mais complexa, pois não se trata apenas de que o passado perdeu sua autoridade sobre o presente ou de que o pensar e o julgar já não possam contar mais com a luz emanada da tradição. O fato de que a ruptura esteja instalada não significa, aos olhos de Arendt, que se possa atribuir a ela o mesmo significado dado à política e à educação. Pode-se dizer que desde que o passado deixou de lançar sua luz sobre o futuro, a mente do educador vagueia nas trevas, mas, aos olhos dos recém-chegados, os educadores representam o presente e o passado, e não podem se furtar a estabelecer essa ponte entre si e seus alunos. É nesse diálogo entre presente e passado que é possível manter uma abertura para o futuro.

Entre as crianças, os jovens, os adultos e os velhos, cada qual representa simbolicamente uma melodia autônoma na suíte política de Arendt. Mas, como toda suíte, essas vozes se interpenetram. Por vezes, geram silêncios e até ruídos, mas também acordes maiores, que costumam ser alegres, ou menores, quase sempre tristes. Não é raro que resultem numa dissonância, sugerindo uma tensão que pode ou não se resolver naquele acorde fundamental e reconfortante aos ouvidos. O fato é que todas as melodias ali presentes, ainda que surgidas em diferentes tempos, podem resultar em ouvidos abertos ao futuro, mesmo que de maneiras distintas.

Quando visto à luz do prefácio de Entre o passado e o futuro - especificamente em relação à metáfora musical de uma suíte política -, o divórcio que Arendt sugere entre educação e política mais parece um exercício ao piano para seis mãos do que uma fronteira rígida e impermeável. Nesse hipotético exercício, não é difícil imaginar, à esquerda do piano, um senhor octogenário de cabelos brancos; ao centro, o filho, um adulto de meia idade; à direita, o neto. A pauta de uma peça para piano, dada a extensão sonora do instrumento, apresenta duas claves para leitura. A clave de fá, mais grave, é a escolhida pelo avô. Ao filho coube ler as duas claves. Ao neto, reserva-se a leitura da clave de sol, mais aguda, porém mais 
brilhante. Eles penam para tocar uma peça anônima: Suite para tempos sombrios. O avô começa gravemente. Pouco depois, o filho acrescenta um acorde a mais que se harmoniza com aquela abertura. Por fim, o neto entra triunfal com seu solo agudo e ágil. Para quem assiste, parece pouco piano para muitas mãos, e em determinado momento elas inevitavelmente se cruzam, tocam-se, e eles se veem obrigados a recomeçar tudo.

Essa imagem talvez revele melhor o sentido da fronteira entre educação e política. Não para negar a dimensão política da educação, mas para aplicar exclusivamente a ela "um conceito de autoridade e uma atitude face ao passado que lhe são apropriados mas não possuem validade geral, não devendo reclamar uma aplicação generalizada no mundo dos adultos" (ARENDT, 1992, p. 246). Essa "atitude face ao passado" obviamente se remete ao âmbito geral da educação. Mas, no campo das disciplinas escolares, a História emerge aí com uma responsabilidade especialmente apropriada ao seu objeto, pois, como sublinha Cruz (1999, p. 85):

La historia sigue siendo el lugar desde el que pensar porque todo está ahí. Y no ya sólo porque en ella se encuentra todo lo construido, sino por algo mucho más importante: porque es el único ámbito donde localizar ese orden secreto que nos constituye. Volverle la espalda equivale, por ello mismo, a renunciar a toda expectativa de sentido, a asumir el presente como una fatalidad, como un destino.

\subsection{Uma herança sem testamento}

Ainda no prefácio de Entre o passado e o futuro, Arendt (1992) reflete com notável densidade sobre o problema da temporalidade e da perda de orientação ocasionado pela terrível experiência da Segunda Guerra e do Holocausto. Ela abre o texto com este aforismo do poeta René Char, que lutara na Resistência Francesa: "Nossa herança nos foi deixada sem nenhum testamento". E Arendt (1992, p. 31) conclui:

O testamento, dizendo ao herdeiro o que será seu de direito, lega posses de um passado para um futuro. Sem testamento ou, resolvendo a metáfora, sem tradição - que selecione e nomeie, que transmita e preserve, que indique onde se encontram os tesouros e qual o seu valor - parece não haver nenhuma continuidade consciente no tempo, e portanto, humanamente falando, nem passado nem futuro.

Essa reflexão política que problematiza a ideia da durabilidade do mundo revela como Arendt, Tocqueville e Char compartilham aquela admiração pelo passado que não se 
confunde com nostalgia nem com melancolia, ${ }^{140}$ mas que reflete uma aguda percepção de que o presente é uma fissura entre forças que se opõem - o passado e o futuro - e de que é nessa brecha que se instaura o pensamento.

Num ensaio cujo mote é o esvaziamento da política no mundo contemporâneo, o filósofo Franklin Silva (2001) empreende uma refinada análise sobre a temporalidade que atualiza a questão deixada em aberto por Arendt e tem profundas implicações quanto à dignidade da educação e ao sentido formativo do ensino de História. Diz ele que as ideias de passado, presente e futuro vêm perdendo densidade. Tomando como exemplo a noção de progresso do Iluminismo, mostra que o otimismo iluminista tinha uma dívida com o presente, ao qual estava indissoluvelmente ligado, de forma que a estabilidade do presente era a própria medida pela qual se fiava o futuro.

O autor conclui que o móbil da mudança passa hoje por uma transformação profunda: não é mais a estabilidade do presente que joga luz no futuro, mas é sua instabilidade que fornece a chave para vivermos e compreendermos as mudanças que se operam à nossa volta. Entretanto, a densidade do problema da instabilidade vai mais longe, pois se o presente já não confere mais aquela estabilidade, isso se deve ao fato de que ele é vivido e percebido como movimento e mudança, isto é,

[...] como se sua realidade lhe fosse emprestada pelo futuro para o qual ele tende em seu movimento [...]. O que ocorre verdadeiramente é que o futuro como que distendeu-se, esticando-se para trás e tomando o lugar do presente. [...] Pois o futuro deixou de estar além do presente, [como na perspectiva iluminista] à nossa frente, para estar no presente e em nós, como se fora uma invasão do presente pelo futuro (SILVA, 2001, p. 241).

Ainda que a educação não seja o escopo do artigo - o autor tem em mira o esvanecimento da política em razão de uma tecnocracia -, é instigante pensar suas implicações no âmbito educacional, pois se a transformação a que se refere Silva deitou raízes nas mais diversas esferas da vida contemporânea, na instituição escolar ela se faz de modo danoso, tendendo a reduzir a educação a um meio de adaptar os estudantes aos reclamos desse futuro distendido para trás. Ora, o que Silva (2001, p. 241-2) pretende demonstrar

[...] é que a presença do futuro pesa sobre nós e quase nos oprime, porque seu significado deixou de estar relacionado com a promessa e passou a habitar o nosso presente, usurpando esse presente e de alguma maneira fazendo com que ele recue para o passado. [...] Se nos tornamos prisioneiros de um futuro "presentificado", é porque nos apropriamos de nosso futuro de maneira "irreflexiva e irrefletida".

${ }^{140}$ A esse respeito, ver CRESPIGNY; MINOGUE, 1979. 
Ora, a irreflexão se instaura porque o presente perdeu sua densidade com o esvanecimento da política. Silva não faz qualquer menção a Arendt ao longo do artigo, mas o diálogo e a similaridade com o pensamento da autora são inegáveis, especialmente em torno do conceito de movimento utilizado pelos nazistas e ao qual Arendt (1989, p. 515-7) consagra amplo espaço de análise em Origens do totalitarismo:

Embora os nazistas falassem da lei da natureza e os bolchevistas falem da lei
da história, natureza e história deixam de ser a força estabilizadora da
autoridade para as ações dos homens mortais; elas próprias tornam-se
movimentos [...]. O terror é a realização da lei do movimento. O seu
principal objetivo é tornar possível à força da natureza ou da história
propagar-se livremente por toda a humanidade sem o estorvo de qualquer
ação humana espontânea.

Os nazistas contavam o tempo em milhares de anos, e uma palavra recorrente em seu vocabulário era movimento. Um movimento em direção ao futuro com vistas a fabricar a humanidade perfeita sem o inconveniente daquelas partes que comprometem o todo. Para Arendt, nada nesse movimento se estabiliza - nem mesmo o terror quando suas potenciais vítimas já foram eliminadas pelo bem da espécie -, a ponto de a impermanência ser seu modus operandi. Assim, pode-se falar, paradoxalmente, de uma permanência do impermanente quando o terror torna-se prática legal, "quando a lei é a lei do movimento de alguma força sobre-humana, seja a Natureza ou a História” (ARENDT, 1989, p. 517). Voltando à análise de Silva (2001), se nada se estabiliza, se nada é permanente, como o passado pode adquirir algum significado?

Outro diálogo que se vê presente remete à questão da promessa em política, que o autor grifa para chamar atenção e que, para Arendt, era o único remédio à imprevisibilidade das ações humanas, uma vez que as promessas criam ilhas de segurança por meio de acordos mútuos. No entanto, é exatamente essa capacidade política de firmar acordos duradouros que está em vias de desaparecer. Voltando à educação, como ela está implicada naquela apropriação que Silva (2001) considera "irreflexiva e irrefletida" do futuro? Ou o que significa colocar ao alcance dos alunos apenas aquilo que se apoia predominantemente na superfície presente e na valorização do novo, virando as costas para a tradição, aquele legado de tradições públicas e compartilhadas que os educadores deveriam confiar aos seus alunos? Em que medida,

[...] num tempo que conhece a rápida obsolescência de idéias, práticas sociais, valores e saberes, faz sentido ter como meta a iniciação dos jovens numa parcela qualquer dessa herança cultural, trazida nas disciplinas que 
ensinamos, nos valores que professamos, nos procedimentos que adotamos para julgar o verdadeiro, o justo, o belo? [...] o que se encontra de fato, em questão, é o próprio sentido formativo do conhecimento (CARVALHO, 2007, p. 24).

Ora, e dentro dessa parcela de nossa herança cultural, qual é o sentido formativo que uma disciplina como a História pode ter? De que forma ela se inscreve como possibilidade de conferir alguma densidade ao passado, uma vez que a experiência totalitária projeta-se como uma sombra sobre o futuro? Não seria, entre outras razões, voltando a Arendt (1992, p. 131), porque "memória e profundidade são o mesmo ou antes, [porque] a profundidade não pode ser alcançada pelo homem a não ser através da recordação"? Se, de fato, não é ao historiador que recai a fixação de objetivos para o futuro, num certo sentido, não representaria ele a promessa desse futuro, uma vez que aqueles que atuam para transformar o mundo lhe confiam uma memória que se vê constantemente ameaçada pelo esquecimento que pesa sobre a fragilidade de toda ação? Isso é igualmente válido para o professor de História? O que distingue, ou seja, une e separa o trabalho de um historiador e o de um professor? 


\section{O ensino como oficina da História}

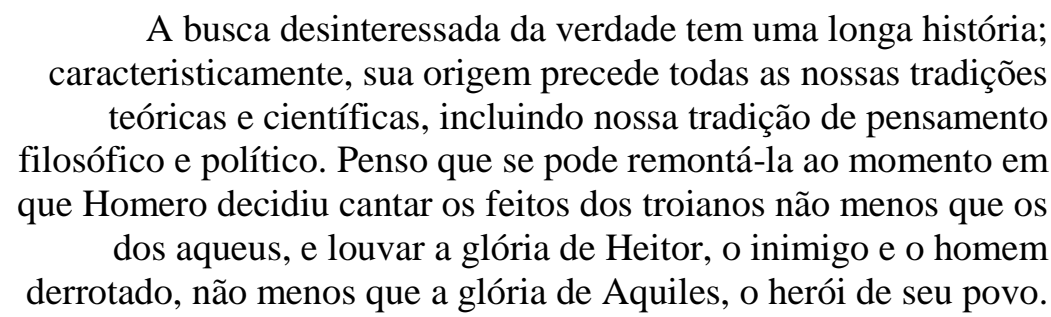

(ARENDT, 1992, p. 323-4)

\subsection{Quando a teoria inventa a prática}

O caminho percorrido até aqui mobilizou diferentes âmbitos pelos quais se move a reflexão arendtiana, como a política, a história e a educação. Tomado isoladamente, nenhum deles pode ser considerado o foco da análise desta pesquisa. Antes, o foco se fragmentou com o propósito deliberado de iluminar um tema em que aqueles âmbitos convergem: o ensino de História. Ora, e porque tomar Hannah Arendt, que não é historiadora, tampouco educadora em sentido estrito, como interlocutora para se pensar o sentido formativo de uma disciplina escolar como a História? Não é suficientemente rico e vasto o legado historiográfico para inspirar ideais formativos (éticos, estéticos, políticos e epistemológicos) no que concerne a essa disciplina escolar? E não existe um razoável número de historiadores que, apesar das querelas específicas de seus campos de pesquisa, procuram manter algum vínculo, em suas reflexões, com o sentido formativo da História na escola fundamental e média?

Ocorre que, como toda relação entre instituições, o intercâmbio que universidades e escolas podem vir a manter entre si também pressupõe certas fronteiras que delimitam diferenças institucionais e culturais que orientam seu funcionamento. Um intercâmbio escolauniversidade que ignore tais diferenças é, no mínimo, temerário, pelo risco de borrar as fronteiras que unem, separam e conformam tais identidades. Das muitas diferenças entre uma formação universitária - que sempre comporta algum grau de especialização - e a generalidade de uma formação escolar - que, nos termos de Arendt, visa a introduzir os novos numa parcela da cultura humana -, há uma que não se deve negligenciar: a entrada numa universidade é concomitante ao ingresso no mundo adulto, o âmbito público da cidadania política no qual os recém-chegados a esse mundo passam a assumir a responsabilidade por ele. Da mesma forma, o ethos que perpassa o modo de vida acadêmico não é aquele que permeia uma instituição escolar. 
$\mathrm{Na}$ perspectiva adotada por Hannah Arendt, a escola é a antessala desse mundo público, uma zona intermediária que se interpõe entre o âmbito privado da família e o caráter público-político do mundo na intenção de promover essa delicada e tensa passagem. Todavia, convém insistir no fato de que apesar de as crianças serem introduzidas ao mundo primeiramente por meio da escolarização, a escola não deve fingir ser o mundo - na estrita acepção que Arendt confere a esse conceito -, tampouco um simulacro do modo de vida que preside as relações políticas entre cidadãos no espaço público. Ainda, talvez se possa acrescentar à análise de Arendt: tampouco deve a escola se constituir como um simulacro do modo de vida acadêmico. É natural que, por ocupar esse lugar de passagem, a escola se revista de ambiguidades que Arendt não pretendia resolver, como também aqui não se pretende. Mas essas ambiguidades ou aporias são sempre um convite ao pensamento.

A essa compreensão se opõe uma ampla rede de discursos acadêmicos no âmbito do ensino de História - solidários entre si e funcionando como uma espécie de comunidade autorreferente -, que, em vez de buscar um modo de pensar a contribuição específica dessa importante disciplina escolar, procura para ela transpor e aplicar os resultados da reflexão acadêmica. Um exemplo frisante dessa perspectiva, que está longe de se constituir num caso isolado, é oferecido por um livro que marcou época: Ensino de História: revisão urgente. ${ }^{141} \mathrm{O}$ tom imperativo do título dá uma mostra de como se apresentava a questão para uma das autoras do livro, Conceição Cabrini. Seu relato resume bem algumas das principais preocupações dos proponentes da renovação. Tome-se a seguinte passagem: "Ensinar História partindo dessa divisão entre saber e não-saber configura um produto acabado e pronto, como que uma verdade absoluta trazida pelo professor e o livro didático ao aluno, cabendo a esse último consumi-lo passivamente" (CABRINI, 2000, p. 33).

Como se vê, o ensino de História precisava ser revisto, e urgentemente, como forma de evitar que os alunos se prostrassem ante as verdades absolutas ou os saberes prontos e acabados que seriam consumidos de forma irreflexiva e passiva. $\mathrm{O}$ fragmento revela que a ideia de um conhecimento capaz de se impor nas relações pedagógicas pelo fato de se encontrar pronto e acabado (e produzido alhures, isto é, na universidade) não visa a elucidar esta ou aquela concepção de conhecimento, mas prescrever um programa de ação pedagógica

\footnotetext{
${ }^{141}$ O livro teve cinco edições pela Brasiliense e foi relançado em 2000 pela EDUSC, em edição revista e ampliada - feito notável para uma obra de assunto tão específico. Trata-se de um relato de experiência com alunos de $5^{\mathrm{a}}$ série (hoje $6^{\mathrm{o}}$ ano) do período noturno, realizado por Cabrini na E. E. P. S. G. Adolfino A. Castanho, no bairro Rio Pequeno, em São Paulo. Cabrini ingressou num projeto financiado pelo MEC com duração de dois anos (1983-1984), obtendo uma bolsa de estudos. A experiência, coordenada por quatro professoras da PUC-SP, resultou na publicação do livro e serviu como modelo para a rede de ensino público paulista por meio do Projeto Noturno, da Secretaria de Educação.
} 
para a renovação do ensino de História. Para a autora, o maior obstáculo à renovação é a concepção de História dos professores, refletida em suas práticas docentes e nos conteúdos cristalizados nos manuais didáticos: ${ }^{142}$

O aluno não se preocupa com as condições de elaboração desse produto acabado que lhe é apresentado e permanece prisioneiro de uma concepção de certa forma mágica ou teleológica do conhecimento do passado: é uma história "revelada". Assim, quando bem sucedido, o aluno organizará, sistematizará e compreenderá o que foi apresentado pelo professor, reproduzindo o conhecimento desse, sem nem imaginar as condições em que esse conhecimento é produzido, o que, na maioria das vezes, até o próprio professor desconhece (CABRINI, 2000, p. 33).

A imagem dos alunos como prisioneiros de uma concepção mágica e revelada lembra o mito da caverna que Platão descreve na República. Mas há uma diferença profunda: lá, quando o personagem faz o caminho de retorno à caverna, após contemplar o céu das ideias eternas, ele é incapaz de comunicar o que viu para aqueles que estavam acorrentados e que só podiam olhar as sombras projetadas na parede da caverna; aqui, ao contrário, desafortunadamente, ele comunica o que pode contemplar. O problema, na perspectiva da autora, é que nem o professor, nem seus alunos (e provavelmente nem o personagem de Platão) se mostram capazes de perceber o caráter mágico e teleológico do conhecimento. Como observa Cabrini, os alunos nem sequer podiam imaginar as condições em que tal conhecimento era produzido pelo professor. Em relação a esse tipo de transposição, Azanha (1995, p. 52) comenta:

A idéia de que a produção do conhecimento em cada diferente área do saber
tem características próprias não permite, sem mais, a passagem para a idéia
de que é o especialista em cada área que está "naturalmente" habilitado para
orientar futuros professores sobre como ensinar nessas mesmas áreas. Esta
passagem ocultaria um erro, cometido dentre outros por Dewey, e que
consiste em supor que o melhor método de ensino é o próprio método pelo
qual a ciência se faz porque o processo de aprendizagem (e,
consequentemente, o de ensino) coincide sempre nas suas fases com aquelas
próprias do método científico.

\footnotetext{
${ }^{142}$ Apesar da crescente importância que cerca o debate sobre o livro didático no Brasil, aqui não se fará uma discussão a esse respeito. A matriz teórica que subsidiou tais críticas, especialmente no âmbito da História, é a obra de Althusser Ideologia e aparelhos ideológicos de Estado. O livro é aí percebido como mais um dos muitos aparelhos ideológicos por meio dos quais o Estado difunde sua ideologia. Ao menos em relação à bibliografia aqui consultada, a crítica mais contundente a essa visão excessivamente instrumental do livro é a tese de doutoramento de Kazumi Munakata, Produzindo livros didáticos e paradidáticos. O autor muda a direção do debate ao propor uma crítica não do livro em si mesmo, mas de um terreno inteiro a ser explorado (e que já vem sendo explorado): o das práticas de uso dos livros didáticos.
} 
Ora, o que parece estar aí em jogo é o equívoco da transposição de um método científico para o âmbito das práticas de ensino. Tal transposição leva a História a deixar de ser um modo de interrogar o sentido e o impacto da prática docente e se transforma num discurso programático (um baú de soluções) para problemas que nascem na prática, mas que se pretende remediar em abstração a partir de questões cuja origem não está na escola, mas na teoria e na prática historiográficas. $\mathrm{O}$ que aqui se pretende examinar não é a pertinência ou não de se familiarizarem os alunos com o método dos historiadores. Muito pelo contrário, este trabalho se une àqueles que pensam, como Hannah Arendt (1992, p. 84), que, “desafortunadamente, é próprio de polêmicas acadêmicas tenderem os problemas metodológicos a obscurecer questões mais fundamentais”, ou, como Azanha (1992, p. 42), que a excessiva preocupação com questões metodológicas parece ter "congestionado os estudos acadêmicos de educação".

Quais questões fundamentais aquele debate obscureceu para ter "congestionado os estudos acadêmicos de educação" no âmbito do ensino de História, ainda muito marcado por aspectos de natureza estritamente metodológica, quase três décadas após o desafio proposto por Cabrini aos professores de História? É evidente que aqui não se imagina que essa modalidade de discurso educacional no âmbito do ensino de História não produza algum efeito na prática docente e que, conforme o caso e a circunstância, não possa ter algum valor estritamente educativo. Não se pode negar, porém, que os problemas cotidianos que afetam os professores de História têm especificidades que vão muito além do desejável domínio teórico da historiografia ou da prática historiográfica em sentido estrito, o que Certeau certa feita chamou de operação historiográfica. A questão parece repousar na justa medida em que as prescrições inerentes ao discurso educacional poderiam ser equilibradas. A esse respeito, Carvalho (2013a, p. 69) observa:

O que se espera de um discurso que almeje modificar um conjunto de práticas sociais historicamente consolidadas como as escolares é que ele as conheça em suas manifestações mais típicas ou freqüentes, em seus condicionantes e resultados e, a partir desse conhecimento, aponte alternativas e as justifique, levando em conta os valores e condicionantes históricos a elas associados.

Ora, essa observação parece não se coadunar com certo tipo de discurso pedagógico que, em vez de procurar conhecer e compreender as práticas docentes no estrito âmbito da cultura escolar, esforça-se por veicular um programa de ação pedagógica que se não chega ao extremo de fazer tábula rasa dos saberes docentes, minimiza o valor educativo que tais experiências formativas possam ter. Diante disso, não é o caso de se pensar que a salutar 
fronteira entre escola e universidade foi ignorada? Que talvez exista nesses esforços uma transposição indevida e danosa do ethos que preside a cultura historiográfica em detrimento da cultura escolar e das práticas docentes que emergem no âmbito do ensino de História? Tome-se o exemplo de Cruz (1984, p. 28, grifo nosso):

$\mathrm{Na}$ verdade, entre nós profissionais de História o mais comum é a reprodução daquela postura que separa os que produzem o saber, junto com a atividade de docência - é claro - daqueles que só ensinam. Na verdade estamos hierarquizados e assumimos esta hierarquia - ser docente é diferente de ser professor [...]. Por que a concepção corrente é a de que o professor de $1^{o}$ e $2^{o}$ graus no seu espaço de trabalho é um mero reprodutor e não produtor de conhecimento? [...] Sem dúvida, é esta a questão, de fundo, no embate por um ensino e uma escola mais democrática.

A análise de Cruz aponta para a distinção entre ser um professor universitário e ser um professor numa instituição escolar. Ao primeiro competiria a produção e o ensino no âmbito universitário, ao passo que ao segundo caberia a mera reprodução daquele conhecimento produzido em outra instância e não a produção do conhecimento histórico. A questão é que Cruz não faz uma análise circunscrita a uma questão de natureza epistemológica, mas vincula o processo de produção-transmissão a um problema de natureza política. Para ela, a ausência de um ensino e de uma escola democrática derivava do fato de que os professores não estavam autorizados a produzir seu próprio conhecimento, uma associação no mínimo problemática. Mais ainda quando o verdadeiro obstáculo para a construção de uma sociedade democrática é atribuído menos à hierarquia universidade versus escola perante a produção do conhecimento, e mais à assimetria de poderes implicada numa relação pedagógica, que é o caso em Iokoi (1984, p. 112):

A experiência de ensino-aprendizagem tem sido muitas vezes truncada, na medida em que o educador se coloca com poder frente ao educando. Poder do saber, da autoridade que conhece os assuntos de maneira absoluta, pois eles são de sua "especialidade". [...] O ato criativo do ensino-aprendizagem deixa de existir e o educando, inferiorizado por sua "ignorância", sente-se mero receptor de informações e visões de mundo do outro, onde o princípio da autoridade é o elemento fundamental.

Ora, a autoridade do professor, que para Arendt consistia não tanto no simples domínio de determinada disciplina escolar, mas na responsabilidade que ele assume pelo mundo e pela iniciação das crianças e dos jovens em uma parcela da cultura humana, é percebida por Iokoi como um verdadeiro obstáculo a separar professores e alunos em relação ao conhecimento. A flagrante indistinção entre política e educação - provocada pela herança 
do regime militar e por suas intervenções no âmbito da educação - produz uma grande confusão entre autoridade e autoritarismo. A luta legítima contra o arbítrio e o autoritarismo no plano político é assim confundida com a assimetria entre professor e aluno, elemento constitutivo e consubstancial à própria relação educativa. O que se insinua é que uma vez superada a assimetria de poderes da relação pedagógica, o ensino de História se encontraria numa outra condição, necessariamente melhor do que aquela que as duas autoras criticam e que concebe o aluno como um "mero receptor de informações e visões de mundo do outro", isto é, um sujeito passivo à espera de um depósito. ${ }^{143} \mathrm{~A}$ ideia de que um aluno só possa reagir passivamente na relação pedagógica apenas adquire sentido à luz dos dilemas políticos então vividos, momento em que a noção de autoridade vivia esquecida em meio às preocupações com o autoritarismo ${ }^{144}$ e em que o país era sacudido por um legítimo debate sobre a democratização da escola pública. ${ }^{145}$

É isso o que se percebe, por exemplo, quando Cruz diz que "ser docente é diferente de ser professor". A afirmação não é feita no sentido de corroborar a distinção entre ser docente (um professor universitário) e ser professor numa instituição escolar. Antes, o objetivo da autora é contestar a distinção. E ela o faz admitindo a equivalência de papéis entre educador e educando, corroborando a ideia de que a relação entre professor e aluno é análoga à isonomia que preside as relações políticas entre cidadãos. Ora, se a igualdade é um princípio fundamental na perspectiva da cidadania, derivar esse princípio para a instituição escolar pode ter o efeito de abolir os procedimentos que regem seu funcionamento. Como sublinha Carvalho (2013b, p. 39-40),

[...] enquanto a marca do caráter político de uma relação é seu compromisso com a igualdade entre os que nela estão envolvidos, a de uma relação pedagógica é o mútuo reconhecimento da assimetria de lugares como fator constitutivo de sua natureza e, no limite, como sua razão de ser. Uma assimetria cujo destino é o progressivo e inexorável desaparecimento, mas cuja manutenção temporária é a própria condição de proteção daqueles que são recém-chegados à vida e ao mundo.

\footnotetext{
${ }^{143} \mathrm{O}$ conceito de Paulo Freire de uma concepção bancária de educação estava muito presente nessa modalidade de discurso, ainda que nem sempre explícito. Sob esse aspecto, Silva (1999, p. 61) comenta que, contrariamente à representação que em geral se faz da obra de Paulo Freire, o autor "concede uma importância central, em seu 'método', ao papel tanto dos especialistas nas diversas disciplinas, aos quais cabe, ao final, elaborar os 'temas significativos' e fazer o que ele chama de 'codificação', quanto aos educadores diretamente envolvidos nas atividades pedagógicas".

${ }_{144}$ Cf. PENTEADO, 1986.

145 Convém ressaltar que, à época, esse importante debate nunca logrou consenso, tampouco se expressou de forma sistemática e convincente; ao contrário, dividiu opiniões. A esse respeito, ver AZANHA, 1979. Uma releitura desse artigo pode ser apreciada em CARVALHO, 2013a.
} 
Longe de reconhecer essa assimetria, pressuposto que antecede a própria relação pedagógica e que a constitui, os proponentes da renovação frequentemente buscam associá-la às relações de dominação - não é raro encontrar variações da máxima saber é poder ${ }^{146}$-, à obediência ou à imposição de "visões de mundo do outro, onde o princípio da autoridade é o elemento fundamental", como observou Iokoi.

É evidente que as práticas docentes não estão infensas às transformações que afetam o exercício dos historiadores profissionais, nem aos modismos pedagógicos. Temos aí uma influência que pode ser profícua. Ela existe e tudo leva a crer que continuará existindo, a despeito das crises teóricas no seio da comunidade de historiadores e daquelas vividas entre professores de História do ensino fundamental e médio. Entretanto, convém separar os aspectos da crise nesses dois âmbitos, bem como as respostas encontradas para os problemas que afligiam e afligem historiadores e professores, pois em toda crise, dirá Arendt (1992, p. 227), “é destruída uma parte do mundo, alguma parte comum a todos nós". Aqui se vai argumentar que a crise que acometeu o ensino de História nas últimas décadas, bem como as respostas encontradas para os impasses dela decorrentes, podem ter resultado no obscurecimento do sentido formativo da História.

Assim, é necessária uma crítica à transposição e à posterior aplicação do processo que rege a atividade do historiador profissional para o campo das práticas pedagógicas. Ao alegar que a tarefa precípua do ensino é levar o aluno a fazer História (com "h" maiúsculo, isto é, conceber uma narrativa, imprimir uma autoria), uma rede solidária e autorreferente do discurso pedagógico - muito representativa, embora haja vozes dissonantes entre os debatedores do ensino de História - acabou enredada numa retórica prescritiva realizada em abstração da cultura escolar. Um possível efeito dessa transposição, e que tem consequências éticas e políticas de grande envergadura, traduz-se na recusa da autoridade e da responsabilidade dos professores perante o passado histórico com o propósito (implícito ou explícito) de transformar os alunos, esses recém-chegados, em historiadores-mirins.

\footnotetext{
${ }^{146}$ Na mesma coletânea Repensando a História, Silva (1984, p. 16) sublinha: "Ideologia e Poder de Classe são questões indissociáveis e o tema aqui debatido [ensino, ideologia e conhecimento] só pode ser encaminhado levando-se em conta quais ensinos de História no $1^{\circ}$ e no $2^{\circ}$ graus interessam à estrutura de poder existente numa formação social específica e que margens de atuação sobram para quantos se dispõem a enfrentar aquela estrutura de poder. Todo o processo de produção do conhecimento [...] precisa ser examinado para que se esboce algum salto contra-ideológico na discussão do ensino da História no $1^{\circ}$ e no $2^{\circ}$ graus".
} 


\subsection{Quando o processo toma o lugar da coisa em si}

Na segunda seção de seu ensaio sobre a crise na educação, Arendt procede à crítica de três pressupostos que, em sua visão, subjazem às reformas escolares modernizantes que marcaram os discursos educacionais a partir das primeiras décadas do século XX. Para os propósitos deste trabalho interessa refletir apenas sobre o terceiro desses pressupostos: o de que "só é possível conhecer e compreender aquilo que nós mesmos fizemos" (ARENDT, 1992, p. 232), dada a repercussão que alcançou no debate sobre o ensino de História.

A origem de tal pressuposto, apresentada no terceiro capítulo, remonta à emergência da ciência moderna e resultou, inclusive no âmbito da moderna consciência histórica, num deslocamento do interesse das coisas para os processos que as constituem, na substituição da contemplação pela experimentação como forma de produção do conhecimento. $\mathrm{O}$ Pragmatismo veio dar ao pressuposto uma expressão conceitual e sistemática e, uma vez transposto ao âmbito da educação, resultou no princípio pedagógico de "substituir, na medida do possível, o aprendizado pelo fazer" (ARENDT, 1992, p. 232).

Entre os muitos desdobramentos da adoção pedagógica desse pressuposto está o cultivo da chamada aprendizagem por meio de métodos ativos, isto é, de que um conhecimento só se torna legítimo quando resulta da própria ação do aluno (concebido como sujeito cognoscente ou sujeito epistêmico). Nessa concepção, o que se põe em questão, portanto, é a própria ideia de que o ensino seria a transmissão intergeracional de uma herança simbólica, comum e pública, e de que o papel do professor seria o de iniciar as novas gerações nesse legado. De acordo com essa perspectiva, em contraste com aquele professor que impunha um conteúdo prescrito, um conjunto de valores e experiências, prega-se a necessidade de um professor concebido como mediador ou facilitador da aprendizagem; em oposição a um aluno presumivelmente passivo, identificado como mero receptáculo daquele saber, fala-se de um aluno que deve se transformar num sujeito ativo do conhecimento.

Como sublinha Arendt (1992, p. 232), tal concepção pragmática - difundida sob o rótulo comum de pedagogias ativas ou não diretivas, dentre as quais se encontram os discursos construtivistas em educação, para os quais o aluno constrói seu próprio conhecimento - postulava que o professor evitasse transmitir um conhecimento petrificado, mas demonstrasse constantemente como o saber é produzido; em outras palavras, que o 
professor não se ocupasse em ensinar conhecimentos, mas inculcasse uma habilidade ou uma competência. $^{147}$

O emprego cada vez mais recorrente nos discursos educacionais, como também na imprensa escrita, no rádio e na televisão, de que uma educação de qualidade deve promover habilidades e competências nos alunos é que ensejou a ideia de uma oficina da História, aqui empregada de forma alegórica e emprestada da obra homônima de F. Furet (L'atelier de l'Histoire). Foi essa a maneira encontrada para analisar, adiante, alguns discursos sobre o ensino de História que, ao pretenderem renovar práticas docentes tidas por tradicionais, elegeram como finalidade do ensino a aquisição - quando não a pura mímesis -, por parte dos alunos, dos procedimentos que regem a atividade do historiador profissional.

A oficina é o local por excelência do homo faber, e a atividade deste consiste na fabricação de uma infinidade de coisas "cuja soma total constitui o artifício humano, o mundo em que vivemos" (ARENDT, 2005a, p. 183). Ao contrário da prática educativa - que, a exemplo da ação política, certamente comporta alguma imprevisibilidade e indeterminação no que tange aos seus resultados -, o processo de fabricação se caracteriza por ter um início e um fim previsíveis. Em face da fragilidade da ação educativa, todo o processo que preside a fabricação se reveste de profunda solidez. A começar pela possibilidade do uso de ferramentas e máquinas, engenhos produzidos para facilitar a transformação da matéria que adentra o processo fabril e é transformada num produto. Mas a oficina também pode ser um local de aprendizagem, ainda que somente com muito esforço se possa concebê-la à imagem do ensino, ${ }^{148}$ como uma relação que vincula um professor aos seus alunos, de forma deliberada e institucional, numa formação.

A oficina da História, numa primeira aproximação, não tem um professor, mas um mestre. E ele não parece muito comprometido com a iniciação daqueles que são recémchegados ao mundo a uma parcela da cultura humana, a um conjunto de realizações simbólicas, comuns e públicas que determinada sociedade elegeu como uma herança a ser compartilhada. Na oficina da História o mestre cumpre o papel de instruir, treinar e

\footnotetext{
${ }^{147}$ Vale ressaltar que não estava no horizonte da análise de Arendt discutir a validade do postulado pragmático ou de sua transposição e aplicação ao estrito campo da educação. Interessavam a ela as consequências políticas dessa transposição que, aos seus olhos, punham em xeque as razões em nome das quais educamos e não meramente instruímos ou treinamos aqueles que são recém-chegados ao mundo.

${ }^{148}$ Sobre o caráter deliberado de educar por meio do ensino, Carvalho $(1998$, p. 25) sublinha: "Se é fato que todos os seres humanos educam e ensinam a outros seres humanos, também é fato que o professor o faz não acidental ou eventualmente, mas tem no ensino e na educação sua escolha de inserção profissional e social. Para nós, professores, educar através do ensino é mais do que uma contingência da condição humana, é uma escolha profissional, que exercemos em instituições, com regras, saberes e inclusive hierarquias que lhe são peculiares".
} 
adaptar $^{149}$ seus aprendizes em métodos, habilidades e competências que até aquele momento constituem segredos recônditos de seu ofício: fazer História.

Fazer história, como se propõe aqui, pode começar pelo que seria a inversão de um quebra-cabeças: o acontecimento pronto e acabado, que sempre compõe uma imagem que ambiciona abranger a totalidade do processo, deve ser decomposto para denunciar aos espectadores o arbítrio de sua construção, como se alguém mostrasse à platéia que fios invisíveis sustentam os truques de ilusionismo do mágico - tão sobrenatural quanto qualquer um de nós (MICELI, 1988, p. 34, grifos nossos).

Um professor que, no ensino de $1^{\circ}$ e $2^{\circ}$ graus, possibilite aos alunos o acesso ao conhecimento histórico produzido e às suas controvérsias, familiarizandoos com os métodos e procedimentos empregados pelo historiador e, o mais significativo, leve-os a aprender História fazendo-os produzir História. Em suma, um professor de História capaz de produzir e ensinar História levando seus alunos, no $1^{\circ}$ e no $2^{\circ}$ graus, a construírem conhecimento histórico - é essa a imagem do professor de História desejável, que emerge das discussões travadas em encontros de professores universitários e dos estudos que abordam o problema da formação do professor [...]. Esse "professor ideal" existe no cotidiano de nossas escolas de $1^{\circ}$ e $2^{\circ}$ graus? (VILLALTA, 1992/3, p. 223-4).

Antes que se percorra essa hipotética oficina da História, em que os truques de ilusionismo cedem lugar à desconstrução e em que os aprendizes vão se familiarizar com os meios, isto é, com "os métodos e procedimentos empregados pelo historiador" a fim de "construírem conhecimento histórico", convém especular que Isak Dinesen, que se dizia "uma contadora de histórias e nada mais" - e cujo interesse primordial era "a história em si e a maneira de a contar" (apud ARENDT, 1991, p. 117) -, dificilmente se sentiria à vontade nessa oficina. E a razão é muito simples: nela já não se contam histórias, pois isso passa a ser visto como um ato arbitrário. Ali não se deve transmitir um conhecimento petrificado ou pronto e acabado, ${ }^{150}$ mas demonstrar continuamente como se fabrica a História, como se constrói uma narrativa, pois, afinal, o pressuposto que anima a oficina da História é o de que

\footnotetext{
${ }^{149}$ Não se pretende negar que o treinamento, a instrução e a adaptação também são componentes de uma relação de ensino e podem estar presentes num processo formativo, mas sim afirmar que reduzir o ensino a tais componentes é no mínimo temerário, pois resulta num "processo de crescente submissão da educação escolar à lógica instrumental que reduz o ideal de uma formação educacional ao de uma funcionalidade em termos de conformação social [...] de forma a despojá-la de seu sentido intrínseco: a iniciação dos mais novos em heranças simbólicas capazes de dar inteligibilidade à experiência humana e durabilidade ao mundo comum" (CARVALHO, 2013a, p. 103).

${ }^{150}$ Em sua obra A linguagem da educação, o filósofo da ciência Israel Scheffler analisa alguns aspectos que aparecem com frequência nos discursos educacionais, em particular o emprego de definições, slogans e metáforas. A expressão pronto e acabado é um caso claro de um slogan educacional. Scheffler (1974, p. 46) sublinha que "os slogans proporcionam símbolos que unificam as idéias e atitudes chaves dos movimentos educacionais. Exprimem e promovem, ao mesmo tempo, a comunidade de espírito, atraindo novos aderentes e fornecendo confiança e firmeza aos veteranos. Assemelham-se, assim, aos slogans religiosos e políticos e, como esses, são produtos de um espírito partidário".
} 
só se compreende aquilo que se faz por si mesmo. Tudo que chega arbitrariamente pronto $e$ acabado deve ser denunciado como ilegítimo. Seria o caso de recordar, voltando a Arendt (1992, p. 120), que os "feitos humanos, a menos que sejam rememorados, são as coisas mais fúteis e perecíveis que existem na face da terra", e que "dificilmente eles sobrevivem à própria atividade e, certamente, jamais podem aspirar por si mesmos àquela permanência que até mesmo os objetos de uso ordinário possuem quando sobrevivem a seu fabricante, para não mencionar as obras de arte, que nos falam após séculos”.

Parece ser sintomático que, em períodos de intensas transformações e crises de um regime político - como as transições de um regime autoritário para um regime democrático e vice-versa -, educadores entrem em cena reivindicando amplas reformas dos sistemas de ensino até então vigentes, reformas que afetam desde os conteúdos curriculares até a forma mais adequada de ensiná-los. No caso do ensino de História, cuja origem como disciplina escolar sempre esteve associada à formação da identidade nacional, ${ }^{151}$ esses momentos de crise despertam acaloradas paixões e não é raro que elas extravasem o estrito âmbito da educação, despertando a atenção de governantes, parlamentos, imprensa, universidades e amplos setores da sociedade civil numa verdadeira guerra das narrativas (LAVILLE, 1999). ${ }^{152}$

Em seu ensaio Verdade e política, Arendt recorda, por exemplo, como na então União Soviética uma personagem da envergadura de Trotsky simplesmente desapareceu dos livros de História com a chegada de Stálin ao poder. A autora evoca essa lembrança, entretanto, apenas para ilustrar o fato de que se é verdade que cada geração tem "o direito de escrever sua própria história", isso significa tão somente "o direito de rearranjar os fatos de acordo com sua própria perspectiva", mas não "o direito de tocar na própria matéria fatual” (ARENDT, 1992, p. 296).

A renovação do ensino de História no Brasil das últimas décadas, especialmente no período de transição do autoritarismo para a democracia, não fugiu, como era de se esperar, a uma apaixonada guerra de narrativas, resultando numa completa reescritura e num rearranjo da História ensinada. A hipótese que aqui se levanta é a de que a vítima dessa guerra de narrativas não foi, como temia Arendt em fins dos anos 1960, a verdade factual, mas a própria narrativa ou arte de contar histórias.

\footnotetext{
${ }^{151}$ A esse respeito, ver, por exemplo: MATTOS, 2000; BITTENCOURT, 1990.

${ }^{152}$ Laville recorda casos recentes dessa guerra de narrativas em torno do ensino de História em momentos de transição política, como o da união das duas Alemanhas, o da África do Sul após a vitória eleitoral de Mandela, o da Rússia durante o período da glasnost, o da República Tcheca pós 1989 e o caso chinês depois da reanexação de Hong Kong, entre outros.
} 


\subsection{Nasce um paradigma}

No Brasil, desde fins dos anos 1970, momento de abertura política do regime autoritário, e mais explicitamente ao longo dos anos 1980, o ensino de História esteve em intenso debate. ${ }^{153}$ No âmbito acadêmico, tal debate foi pautado pela Revista Brasileira de História, prestigioso periódico vinculado à ANPUH (Associação Nacional dos Professores Universitários de História). As linhas centrais da revista soavam como um eco tardio do fervor militante presente ao longo da ditadura militar e dos bem-sucedidos esforços em prol da redemocratização do país. Dos muitos que então cerraram fileiras nessa cruzada por uma renovação do ensino de História, escolheu-se uma destacada interlocutora: Déa Ribeiro Fénelon, professora de História da Pontifícia Universidade Católica de São Paulo (PUC-SP).

João Pessoa, julho de 1981. A professora Fénelon toma a palavra no XI Simpósio Nacional da ANPUH e lança os fundamentos de um debate sobre ensino de História que ecoaria até a publicação dos Parâmetros Curriculares Nacionais, em fins dos anos 1990, momento em que a discussão sobre o assunto arrefece. Intitulado A formação do profissional de História e a realidade do ensino, o texto apresentado pela autora faz um duro diagnóstico da universidade: encerrada sobre si mesma, despolitizada, burocratizada. Vivia-se, então, sob aquele que seria o último governo do ciclo militar iniciado em 1964: o mandato do general João Baptista Figueiredo (1979-1985), caracterizado, essencialmente, pela continuidade da lenta abertura política iniciada por seu antecessor, Ernesto Geisel, combinada a uma crise econômica que se agravava e à emergência dos movimentos sociais urbanos e de um novo sindicalismo surgido no ABC paulista.

Em anos anteriores, parcelas significativas da intelectualidade, do movimento estudantil e das universidades haviam desempenhado o papel de principais representantes da oposição ao regime militar. No início dos anos 1980, num momento de fortalecimento da sociedade civil organizada, surgiam novos atores ${ }^{154}$ políticos. De forma muito pertinente, Fénelon percebe esse deslocamento do papel da universidade e, particularmente, dos historiadores. Já na abertura da palestra, a autora se pergunta:

De que realidade estamos falando quando dizemos que a História é importante porque nos ensina a analisar a realidade para podermos transformá-la? [...] Não tenho dúvida de que para fazer avançar qualquer

\footnotetext{
${ }^{153}$ Cf. CORDEIRO, 2000.

${ }^{154}$ Cf. SADER, 1988.
} 
proposta concreta como professores de História temos de assumir a responsabilidade social e política com o momento vivido. Para isso seria necessário, antes de mais nada, romper com uma maneira tradicional de conceber conhecimento, sua produção e sua transmissão (FÉNELON, 1982, p. 7).

Sob o signo da ruptura, caberia uma dura autocrítica ao papel do intelectual, das Ciências Sociais e da História na sociedade brasileira. Para Fénelon, ao dar as costas à realidade, a universidade não poderia cumprir seu papel de agente da transformação social. Daí o sentido de "assumir a responsabilidade social e política com o momento vivido". Por fim, como resultado dessa recusa, Fénelon aponta a disjunção entre a produção da ciência, as políticas públicas de educação e a sociedade como problema que urgia ser remediado.

Uma primeira questão que se impõe aqui diz respeito às responsabilidades e contribuições que uma universidade tem a oferecer à ciência, bem como ao papel político que ela exerce em determinada sociedade. Embora seja legítimo Fénelon buscar persuadir o auditório sobre a assunção da responsabilidade política da comunidade de historiadores - um ato corajoso, tendo em vista que a censura e as perseguições políticas do regime militar também atingiam professores universitários -, é problemático inferir daí que a "História é importante porque nos ensina a analisar a realidade para podermos transformá-la”. A assunção da responsabilidade pelo mundo comum, tema caríssimo a Arendt e abordado ao longo deste trabalho, dificilmente implicaria a tentativa de fabricar o futuro por meio de uma instrumentalização do ensino universitário. Antes, ela poderia implicar que o professor,

[...] aquele que diz o que é - légei ta eónta - sempre narra uma estória, e nessa estória os fatos particulares perdem sua contingência e adquirem algum sentido humanamente compreensível. [...] $\mathrm{Na}$ medida em que o contador da verdade dos fatos é também um contador de estórias, ele efetiva aquela "reconciliação com a realidade" (ARENDT, 1992, p. 323).

Em outras palavras, tomar aquelas circunstâncias políticas - a natureza de um regime autoritário, as perseguições políticas, a censura prévia, a violência da tortura, enfim - como tema de reflexão e debate seria não apenas justificável à luz do pensamento de Arendt, mas um ato de coragem política, coragem esta que não faltou à professora Fénelon. Entretanto, se, como Arendt insistia, a compreensão é o outro lado da ação, debater tal conjuntura seria uma forma de buscar compreendê-la, pela simples razão de que o mundo não se torna humano apenas quando os homens decidem agir em conjunto, mas também quando se reúnem, como naquela ocasião em João Pessoa, para travar um diálogo buscando reconciliar-se com aquilo que fazem e sofrem. 
Outra inferência, no mínimo questionável, é a de vincular a assunção da "responsabilidade social e política com o momento vivido" à necessidade de "romper com uma maneira tradicional de conceber conhecimento, sua produção e sua transmissão". Ora, a tomada de uma posição política não necessariamente coincide com o levantamento de um problema epistemológico, ainda que em conjunturas de crise política, como era o caso em que se deu a palestra, essas fronteiras entre política e educação tornem-se obscurecidas, como fica mais perceptível na seguinte passagem:

Se aceitamos então essa dissociação [...] entre ciência e o social [...] estamos assumindo na prática um modo de pensar a nossa disciplina, a História, e o seu ensino e a pesquisa, dentro de um esquema tradicional, onde a Universidade é sempre pensada como centro de produção do saber, ou como diria Michel de Certeau, [...] no "lugar social" de onde falam os cientistas [...] estamos simplesmente formando reprodutores de uma ciência já pronta e acabada sem nenhum referencial teórico ou metodológico, senão aqueles das teorias já cristalizadas e estáticas (FÉNELON, 1982, 9-11).

Fénelon ressalta o abismo que então separa, aos seus olhos, a comunidade científica e a sociedade. A referência ao historiador francês Michel de Certeau visava a ressaltar que a operação histórica, isto é, a prática historiográfica, está estreitamente vinculada ao lugar social do qual brota o discurso do historiador e de determinado domínio técnico por meio do qual ele conduz uma investigação de natureza histórica, de modo que esse lugar, obviamente, não é neutro. Entre nós, porém, a recepção tanto do texto de Certeau quanto do de Fénelon foi simplificada ao adágio baconiano de que saber é poder, resultando na identificação da universidade como lugar do discurso competente, enclausurado numa torre de marfim.

Fénelon prossegue fazendo um balanço da herança dos anos de exceção e sublinha a tentativa de controle exercida pelo Estado sobre as ciências humanas no interior da universidade e da escola. No caso em questão, essa tentativa de controle se fez por meio do banimento da História como disciplina escolar e de sua substituição pela introdução das disciplinas Educação Moral e Cívica, Estudos Sociais e O.S.P.B. (Organização Social e Política do Brasil). A autora insiste, ainda, que a própria universidade sucumbiu à burocratização ao criar obstáculos a uma verdadeira formação, seja a do pesquisador, seja a do profissional da educação, permitindo que se atribuíssem as mazelas - convenientemente, segundo ela - à má formação com que o aluno supostamente chegava às universidades. Quanto à produção e à transmissão do conhecimento histórico, Fénelon (1982, p. 17) sustenta: 
Não é difícil reconhecer nestes resultados os efeitos e os sintomas da proclamada separação entre ensino e pesquisa [...] e que teoricamente reconhecemos como perniciosa, mas que em nossa prática acaba por se concretizar como linha de trabalho, mesmo porque não se tem muita clareza do que seja o treinamento para a investigação. Grande parte de nossos alunos são formados em História mas não são capazes de elaborar uma problemática de pesquisa.

Em momento algum a autora atribui culpa ao aluno de graduação pelos problemas por ela levantados. Ao contrário, aponta a disjunção entre ensino e pesquisa como a responsável pela formação de futuros professores que quase nunca foram expostos ao problema de conduzir uma investigação e que raramente aprenderam "a fazer ciência, a fazer História e fazer História significa lidar com a sociedade, objeto dinâmico e em constante transformação, aprender a reconhecer seus próprios condicionamentos sociais e sua posição como agente e sujeito da História”. Em relação ao fato de que o aluno não aprendeu, conclui a autora:

O saber é transmitido como já resolvido, simplificado aos manuais, e certamente rotulado e transformado em saber cristalizado [...]. Por isso estamos insistindo na necessidade de não apenas valorizar, mas realmente começarmos a realizar a pesquisa e a produção, desde o curso de graduação e de todos os níveis de ensino (FÉNELON, 1982, p. 19).

No contexto de abertura política em que a palestra foi proferida, fica evidente a veemência com que a autora enfrenta o tema da formação do futuro professor e da realidade do ensino, quer na universidade, quer na educação básica. Não está em questão aqui o caráter militante da palestra de Fénelon e a relação entre a formação de um pesquisador e a presumível dimensão política que a abarca. Para além de questões de ordem puramente epistemológica no campo da História, o fato é que a dimensão política de sua análise proclamava um programa de ação prático que não se circunscrevia ao âmbito universitário.

Ora, é perfeitamente legítimo que Fénelon tentasse persuadir a comunidade de historiadores sobre a necessidade de repensar os critérios da formação do profissional de História (o aluno de graduação, futuro pesquisador) a fim de dotá-lo de instrumentos do mundo da pesquisa para que ele se tornasse um profissional apto a responder às urgências de seu tempo. Mas é no mínimo questionável que isso se realizasse, como ela sugere, em "todos os níveis de ensino". Assim, ao propor que tal reforma fosse transposta para o âmbito das práticas escolares, a análise de Fénelon acabou por fornecer a senha do debate sobre a renovação das práticas docentes no ensino de História.

Convém ressaltar que a mencionada palestra foi proferida num meio institucional - um encontro da ANPUH -, estava endereçada a um público específico - a comunidade de 
historiadores e professores de História no âmbito universitário e na educação básica - e tinha como propósito discutir não apenas o sentido formativo da História, mas veicular um programa político-pedagógico de ação. Assim, é nesse contexto de uma enunciação de caráter programático que seus desdobramentos serão aqui analisados.

De forma geral e esquemática, é possível reunir as proposições de Fénelon em um conjunto de três pressupostos que se relacionam mutuamente e que resumem suas intenções programáticas. O primeiro pressuposto, marcadamente político, é o de que a dissociação entre ciência e sociedade despolitizou o ensino de História na universidade, impedindo que ela cumpra seu papel de formar sujeitos aptos a transformar a realidade ou a fazer História. $\mathrm{O}$ segundo diz respeito ao caráter pernicioso da separação entre ensino e pesquisa, cujo resultado se traduz na mera reprodução-transmissão de um saber cristalizado. Por fim, como a universidade não forma um genuíno pesquisador, torna-se imperioso "começar a realizar a pesquisa e a produção, desde o curso de graduação e de todos os níveis de ensino".

A questão é saber como o desafio lançado por Fénelon, aqui resumido nesses três pressupostos, foi enfrentado pelas gerações seguintes. Para tanto, o exame dos discursos será realizado paralelamente às transformações que então se operavam na teoria e na prática historiográficas, a fim de que se perceba a transposição neles realizada. Uma vez que a maioria dos historiadores trazidos ao debate pelos proponentes da renovação do ensino de História vinculava-se direta ou indiretamente à Nova História, a História renovada de matriz francesa, a ela se dedicará uma atenção especial.

\subsection{Dos Annales à Nova História}

Seria impossível, no exíguo espaço de um capítulo, abarcar todo o leque daquelas transformações que alargaram o campo das práticas historiográficas. Assim, o que se segue tem apenas o propósito de sugerir os mecanismos que comandam um debate epistemológico no âmbito da História acadêmica.

A fim de circunscrever a questão, tomou-se como fio condutor o problema da interdisciplinaridade entre as ciências e de como ele foi tratado entre os adeptos da Nova História, já que a interdisciplinaridade tem sido um tema recorrente no âmbito da educação. Adiante, será possível mostrar que o debate canônico produzido no interior de qualquer disciplina científica está sujeito a regras específicas amplamente compartilhadas pelos 
participantes e que não são as mesmas que orientam a atividade educacional e o sentido formativo de uma disciplina escolar como a História. ${ }^{155}$

Do ponto de vista epistemológico, os historiadores franceses da década de 1970, ao mesmo tempo em que se viam como continuadores de uma tradição que remontava ao trio Bloch, Fevbre e Braudel - em 1929, Lucien Febvre e Marc Bloch fundaram a revista Annales: Économies, Societés, Civilisations -, percebiam o limite de um projeto tão ambicioso como o de seus predecessores. $\mathrm{O}$ alargamento do universo do historiador em direção a uma História totalizante e a reflexão cada vez mais urgente sobre as próprias condições da produção do saber histórico apontavam uma mudança de interesse no ofício do historiador. A produção daquela época é reveladora: Comment on écrit l'histoire, de Veyne, em 1971; Faire de l'Histoire, de LeGoff e Nora, em 1977; L'atelier de l'histoire, de Furet, em 1971; L'opération historique, de Certeau; e La nouvelle histoire, de Le Goff, Chartier e Revel, em 1978. ${ }^{156}$

Esses títulos demonstram uma disposição de autorreflexão sobre a tarefa do historiador no mundo atual, e foi exatamente para dar expressão a essa vontade que Jacques Le Goff e Pierre Nora organizaram e publicaram os três volumes dedicados à História, em 1974, e dez ensaios acompanhados de um amplo dicionário, em 1978. A História se via diante da releitura de seus novos problemas, abordagens e objetos; os historiadores refletiam sobre o estatuto epistemológico do conhecimento histórico. Paul Veyne já havia diagnosticado que os historiadores não poderiam ser os mesmos depois da obra de Foucault, que abriu espaço para problematizar outros objetos que não apenas o Estado, a Igreja, o partido político, mas os microcosmos da fábrica, da família, da sexualidade, do hospital, das clínicas psiquiátricas, enfim. Segundo Veyne, Foucault havia "revolucionado a História". 157

De outra parte, a História se enamorou de distintos campos do saber, como a geografia, a antropologia, a arte, a literatura, a psicanálise, o que, de certo modo, já estava implícito no projeto inaugural de Lucien Febvre e Marc Bloch quando fundaram a revista, em 1929. A obra O Mediterrâneo, de Fernand Braudel, e A sociedade feudal, de Marc Bloch, são significativas dessa interdisciplinaridade, de forma que a ampliação do campo do historiador não era exatamente nova, segundo um dos maiores críticos da Nova História, François Dosse. Aliás, em A História em migalhas: dos Annales à Nova História, o autor mostra a empatia que

\footnotetext{
${ }^{155}$ Cf. SHEFFLER, 1974, p. 21-2.

${ }^{156}$ As respectivas traduções para o português são: Como se escreve a História (VEYNE, 1983); LE GOFF, J e NORA, P. (org.) História: novos problemas, novos objetos, novas abordagens (LE GOFF; NORA, 1988); A oficina da História (FURET, 1986); A operação histórica (CERTEAU, 1988); A História nova (LE GOFF, CHARTIER; REVEL, 1988).

${ }^{157}$ Ver também GRISET, 1986, e RAGO, 2002.
} 
Bloch e Braudel nutriam por Henri Berr, que desde 1900, quando criou a Revue de Synthèse Historique, espécie de prenúncio dos Annales, colocou-se na posição de franco atirador contra a História historicizante, conclamando os historiadores a derrubarem as fronteiras que separavam as diversas Ciências Sociais, em direção a uma perspectiva globalizante dos fenômenos sociais.

Essa historiografia que se renovava também teria de se haver com mudanças de grande impacto no mundo contemporâneo, tais como a descolonização, os movimentos de emancipação de grupos minoritários, os movimentos ecológicos em escala mundial, os avanços da tecnologia eletrônica midiática e certo deslocamento do interesse pela produção para o consumo, por meio das chamadas teorias da recepção, que tiveram profunda influência no âmbito da educação, sobretudo no ensino de História. Tais teorias colocavam em suspeição a tese segundo a qual os consumidores da indústria cultural eram o polo passivo de uma relação de dominação cultural, ideia cara aos teóricos da Escola de Frankfurt, notadamente Adorno e Horkheimer.

Perante esse novo cenário, o campo epistemológico das Ciências Sociais e da História acaba operando certas fusões e, por que não dizer, fissões. Não se sabe mais distinguir onde começa a Ciência Política e termina a Sociologia, onde se inicia a História e acaba a Antropologia, onde se encerra o Jornalismo e nasce a História Imediata. Ora, essa dança de fronteiras tornou urgente a reflexão sobre as condições e os pressupostos de uma história não só do passado, mas igualmente do presente, já que os historiadores são cada vez mais chamados a opinar sobre o imediato e sobre as tendências para o futuro. Como sublinha Saliba (2003, p. 17) na apresentação de A História em migalhas para o leitor brasileiro,

Clio, musa reverenciada na França por um público cada vez mais sequioso de história, parece ter adquirido nos últimos anos uma cidadania universal. A publicação no Brasil, num ritmo cada vez mais intenso, das principais obras da historiografia na última década, cresceu ao embalo da "Nova História" rótulo transformado numa autêntica credencial para tudo aquilo que significasse a última palavra na produção histórica. [...] É inegável que a simples menção a esta herança, real ou ilusória, aumentava as credenciais e fornecia uma difusa legitimidade à "Nova História".

Foi exatamente em busca dessas credenciais que os proponentes da renovação do ensino de História dirigiram seus esforços na intenção de superar o alegado ou mesmo pernicioso divórcio entre ensino e pesquisa. A diferença é que se no estrito campo historiográfico a legitimidade da Nova História era difusa, como sugere Saliba, no âmbito do ensino de História ela se enraizou. Com raras exceções, os proponentes da renovação 
atribuem à Nova História uma homogeneidade no mínimo questionável, uma vez que entre seus adeptos também havia espaço para diferenças.

É verdade que, a despeito de suas diferenças, o que unia os participantes do movimento dos Annales era o fato de compartilharem certa aversão ao positivismo, que transformava a matéria factual numa espécie de fetiche. Os fundadores Febvre e Bloch "pretendiam romper com o ranço positivista de conceitos como os de racionalidade, progresso e ordem, que ainda perduravam na historiografia" (SALIBA, 2003, p. 20) e que propugnavam que o historiador deixasse falar sua documentação, sem nada lhe acrescentar - como se fosse possível uma neutralidade -, restabelecendo os fatos históricos tal qual ocorreram. ${ }^{158}$

Contra essa História-relato, excessivamente calcada na história política em que desfilam os heróis e os documentos oficiais, militares e diplomáticos, ${ }^{159}$ os adeptos dos Annales defendiam uma História-problema. É nessa linha interpretativa que duas importantes proponentes do debate defenderão - contra o fetiche dos fatos que falam por si mesmos - um ensino de História pautado num currículo organizado por meio de eixos temáticos problematizadores. Tomem-se estes dois exemplos:

[...] o domínio da história universal, tal como vinha sendo tratada pela tradição, acabou-se. Atualmente a imagem de "espelho estilhaçado" [...] expressa com mais propriedade o campo da História. [...] A História, portanto, tem sido temática (NADAI, 1992/3, p. 159).

Propomos a Unidade Temática como um meio de [...] se construir uma estrutura teórica que fundamenta a realidade social na qual a criança está inserida. $\mathrm{O}$ tema propicia a existência de situações problema, favorece a pesquisa e dá possibilidade de romper com a história factual (ZAMBONI, 1985/6, p. 119).

O espelho estilhaçado de Marc Ferro ${ }^{160}$ no lugar das migalhas de François Dosse: os termos se equivalem. Se esses historiadores renunciaram à pretensão de uma metanarrativa, a uma explicação global da história, Nadai sugere que os professores de História façam o mesmo. A história universal estaria devidamente sepultada. Ora, mas o sentido formativo da

\footnotetext{
${ }^{158}$ No ensaio Verdade e política, Arendt (1992, p. 296) dá mostras de que estava plenamente consciente dessas questões: "Mas os fatos realmente existem, independentes de opinião e interpretação? Não demonstram gerações de historiadores e filósofos da história a impossibilidade da determinação de fatos sem interpretação, visto ser mister colhê-los de um caos de puros acontecimentos (e decerto os princípios de escolha não são dados fatuais) e depois adequá-los a uma estória que só pode ser narrada em uma certa perspectiva, que nada tem a ver com a ocorrência original?".

${ }^{159}$ Sublinha Le Goff (1996, p. 536): "O documento que, para a escola histórica positivista do fim do século XIX e do início do século XX, será o fundamento do fato histórico, ainda que resulte da escolha, de uma decisão do historiador, parece apresentar-se por si mesmo como prova histórica. A sua objetividade parece opor-se à intencionalidade do monumento. Além do mais, afirma-se essencialmente como testemunho escrito".

${ }^{160}$ Nadai (1992/3) faz referência ao título O espelho estilhaçado, da conclusão da obra de Marc Ferro Falsificação da história.
} 
História não deveria marchar na contramão da implosão que estava ocorrendo na historiografia e que Dosse tão bem apontara? Os proponentes da renovação não poderiam - a exemplo da atitude que Arendt propõe para o educador - oferecer uma resistência conservadora a tais transformações e passar ao largo das disputas encarniçadas em que os historiadores estavam se envolvendo? Em outras palavras, em vez de lançar os alunos no centro dessa instabilidade, não poderiam aqueles procurar protegê-los por meio de uma iniciação em torno de conteúdos minimamente consagrados, estáveis e permanentes?

Em 1989 houve a queda do muro de Berlim; em 1991, o colapso do regime soviético; no ano seguinte, Francis Fukuyama publicou sua ode ao liberalismo, The end of history and the last man. Ora, quando os historiadores saíram catando as migalhas de Dosse para responder à proclamação do fim da história por Fukuyama, Nadai propunha como metáfora do ensino de História o espelho estilhaçado de Marc Ferro. Seria mais prudente tentar juntar os cacos em vez de esparramá-los, como que recusando uma história universal ao propor uma história temática. A conclusão da autora deixa sérias dúvidas, quer quanto à trajetória do ensino de História, quer quanto às perspectivas que ela mesma desenhava para essa disciplina escolar:

Em conclusão, pode-se afirmar que vivemos ainda uma conjuntura de "crise da história historicista", mas as diversas propostas de ensino e as práticas docentes têm ajudado a viabilizar outras concepções de História, mais comprometidas com a libertação e a emancipação do homem. E a História, a mais política das ciências sociais, tem ressurgido das cinzas (onde a ditadura pensou sepultá-la), tal qual Fênix, mais fortalecida do que nunca (NADAI, 1992/3, p. 160).

Que a ditadura militar (1964-1985) tenha pretendido sepultar a história é fato amplamente reconhecido, e aqui se salienta a luta de Nadai e de outros tantos, inclusive da ANPUH, para restituí-la à escola. Mas que em 1993 as diversas propostas de ensino possam ser tomadas como a Fênix ressurgida parece demasiado inverossímil. Não é o caso de entrar em detalhe de que as propostas curriculares de História realizadas ao longo dos anos 1980 e 1990, assim como a publicação em 1998 dos Parâmetros Curriculares Nacionais de História, tenham consagrado uma perspectiva de ensino em torno de eixos temáticos. O que aqui interessa é que mesmo o aparente consenso em torno de uma história temática (a transposição da História-problema dos Annales), capaz de romper com o ranço positivista, também esconde profundas diferenças entre os representantes da Nova História quanto à maneira pela qual elegem e interrogam seus documentos, ou mesmo quanto ao modo como se afastam ou 
se aproximam do projeto das duas primeiras gerações daquela escola ao longo das décadas de 1930 a 1960.

O alargamento do campo do historiador, invadindo as demais Ciências Sociais, tomando de empréstimo seus métodos e expandindo, assim, não apenas seus objetos de estudo, mas sobretudo a forma pela qual os problematiza em termos estritamente históricos, acabou por produzir uma interdisciplinaridade de ciências afins, que passaram a partilhar objetos comuns. No entanto, essa expansão não se deu pela simples soma, um acréscimo virtuoso de abordagens, objetos e problemas novos que instrumentalizariam o historiador em suas criações, preservando a História ou os demais campos do conhecimento do ponto de vista epistemológico. Um olhar crítico sobre essa renovação, como o de Dosse, insiste em que se as duas primeiras gerações dos Annales souberam alargar o campo do historiador, preservando certas fronteiras epistemológicas, isso não parece ser verdadeiro para a terceira geração.

A hegemonia dos Annales só foi possível devido à capacidade de alguns historiadores de assimilar objetos de estudo que estavam fora do domínio da História e que até então eram abordados por outras disciplinas acadêmicas que também aspiravam fornecer os instrumentos por meio dos quais seria possível uma visão integradora, totalizante. É o caso, por exemplo, da escola geográfica de Vidal de La Blache, da sociologia de Durkheim ou da antropologia de Lévi-Strauss. Imagine-se o esforço dos Annales para não serem engolidos por outros projetos de uma megaciência social (uma metanarrativa) e afirmarem a vocação dos historiadores em produzir sínteses, uma vez que autores de outros campos do conhecimento reivindicavam esses mesmos horizontes teóricos. E o que não dizer dos embates que os Annales tiveram com a obra de Marx, ora rejeitando-a, ora assimilando-a de forma renovada? ${ }^{161}$ Mas a que custo a História teve de se alargar para não se ver estreitada pelo projeto de uma ciência social vidaliana, durkheimiana, levi-straussiana e, por que não dizer, foucaultiana? Dosse não está sozinho nessa análise. ${ }^{162}$

A própria resposta apaixonada de Le Goff em defesa da Nova História não negligencia os problemas que Dosse levantou em 1987 quando publicou na França A História em migalhas, título composto por uma expressão tomada de empréstimo de Pierre Nora. No novo prefácio que escreveu para a reedição, em 1988, da obra coletiva La Novelle Histoire,

\footnotetext{
${ }^{161}$ Fora do âmbito dos Annales, pode-se consultar, por exemplo, dois artigos de Hobsbawm em defesa de uma história marxista: $O$ que os historiadores devem a Karl Marx e Marx e a História, ambos incluídos no livro Sobre a História (HOBSBAWM, 1998). Também para uma defesa da abordagem marxista da história, pode-se consultar a obra de Schaff (1974) História e verdade.

${ }^{162}$ Ver, por exemplo, CARDOSO; VAINFAS, 1997, especialmente o ensaio introdutório História e paradigmas rivais. O Dossiê Nova História, publicado pela Revista da USP (n. 23, set./nov. 1994), também pode ser consultado, especialmente o artigo de Renato Janine Ribeiro O risco de uma nova ortodoxia.
} 
inicialmente publicada em 1978, Le Goff reconhece, ainda que parcialmente, os argumentos de Dosse. Na reedição brasileira de A História em migalhas, de 2003, Dosse escreve um prefácio exclusivo para o leitor brasileiro e faz uma defesa da obra que insiste em não alterar, relativizando, entretanto, certos exageros e absorvendo em parte alguns argumentos da defesa de Le Goff sobre as potencialidades da Nova História. Ora, a resultante desse diálogo - que não se encerra, obviamente, entre Dosse e Le $\operatorname{Goff}^{163}$ - é o que se espera de uma tradição pública de debate em torno de ideias e projetos que, em vez de se anularem, podem conviver.

A título de contraponto, apenas com muito esforço é possível tomar o conjunto de ensaios publicados na Revista Brasileira de História como um gesto de abrigar diferentes concepções em torno do ensino de História. Para tanto, o mínimo que se esperaria é que o periódico acolhesse a voz daqueles que não compartilhavam - no todo ou em parte - dos termos em que se propunha a renovação do ensino.

Deixando de lado todos os matizes da crítica de Dosse à terceira geração dos Annales, o que aqui se enfatiza é o alerta que ele faz para o abandono de uma metanarrativa, isto é, uma visão integradora e globalizante do homem no espaço e no tempo. Sendo ora mais, ora menos incisivo com os novos representantes da Nova História, o autor dirige seus esforços rumo a uma tradição que, segundo ele, está sendo recusada, abandonada, e adverte quanto ao risco de a História naufragar como algo imóvel, capaz apenas de ver as permanências, as continuidades, os micropoderes e o cotidiano de nossos antepassados, o que nos chegaria num misto de História e literatura e nos faria prisioneiros de uma história que não existe mais, porque assaltada pela voga irracionalista e pós-moderna da desconstrução.

Se a interdisciplinaridade é um tema canônico na produção da ciência em geral, com polêmicas candentes sobre custos e benefícios nessa dança de fronteiras - indissociáveis de disputas pela hegemonia nos campos do conhecimento -, o discurso educacional, parafraseando Jean Chesneax (1995) quando faz tábula rasa daqueles conflitos, acaba operando uma redução - sempre na chave positiva, é bom que se diga - das intrincadas disputas teórico-metodológicas inerentes à complexa rede daquela disciplina. Onde, então, está o problema? Ao cruzar a fronteira que separa a História como disciplina acadêmica da História como disciplina escolar, o dissenso historiográfico desapareceu e foi transformado no consenso das práticas pedagógicas sobre o quê e como se deve ensinar História. Dito de outra forma, os proponentes da renovação derivam da moderna historiografia sua interdisciplinaridade, seus temas, suas abordagens e seus métodos, e o fazem segundo as

$\overline{{ }^{163} \text { Ver, por exemplo, BURKE, 1992 }}, 1997$ a, bem como as obras citadas na nota anterior. 
mesmas razões presentes no debate historiográfico. Com um agravante, porém: fazem-no apenas na perspectiva positiva e virtuosa, espécie de paideia educativa que elimina toda fronteira entre as disciplinas acadêmicas e as escolarizáveis.

Evidentemente, aqui não se pretende condenar a prática da interdisciplinaridade ou a inclusão de novos temas no currículo escolar, como a história da África e das comunidades indígenas brasileiras. Tampouco se quer afirmar que o professor não deve fazer uso de variadas fontes documentais, como a canção popular, a iconografia, a poesia, a literatura e a cultura material. Mas a defesa de uma prática pedagógica interdisciplinar ou a utilização de documentos para fins didáticos e formativos no espaço escolar deve encontrar argumentos que se justifiquem no interior mesmo dos currículos, das práticas de ensino e das disciplinas escolares, de modo que as razões para fazê-lo sejam tais que possibilitem subscrever os objetivos em termos estritamente pedagógicos e políticos no âmbito da cultura escolar.

Que se retome o desafio lançado por Villalta (1992/3, p. 223-4) aos professores, citado páginas atrás:

Um professor que, no ensino de $1^{\circ}$ e $2^{\circ}$ graus, possibilite aos alunos o acesso ao conhecimento histórico produzido e às suas controvérsias, familiarizandoos com os métodos e procedimentos empregados pelo historiador e, o mais significativo, leve-os a aprender História fazendo-os produzir História. Em suma, um professor de História capaz de produzir e ensinar História levando seus alunos, no $1^{\circ}$ e no $2^{\circ}$ graus, a construírem conhecimento histórico - é essa a imagem do professor de História desejável, que emerge das discussões travadas em encontros de professores universitários e dos estudos que abordam o problema da formação do professor [...]. Esse "professor ideal" existe no cotidiano de nossas escolas de $1^{\circ}$ e $2^{\circ}$ graus?

E que também se veja a resposta por ele proposta: “o 'professor ideal' é cada vez mais ‘uma miragem'. No imenso 'deserto' em que nos encontramos, são pouquíssimos os 'oásis”” (p. 223). Apresentando as conclusões de uma pesquisa de campo realizada em escolas de Belo Horizonte (MG), o autor conclui que o algoz do ensino de História é a própria universidade, que forma mal os futuros professores, uma vez que eles a concluem

[...] sem saber sequer como se redige um projeto de pesquisa. Eles [...] quase nunca manipulam fontes primárias e, quando o fazem, não aprendem como analisá-las. [...] Nessa situação, podemos esperar que nossos pupilos produzam conhecimento histórico após saírem da Universidade? Ou ainda que ensinem História a seus alunos fazendo-os construir conhecimento histórico? São perspectivas completamente irrealistas. [...] Se concebemos como "professor ideal" um sujeito que tem domínio sobre o processo de elaboração do conhecimento e, assim, está em condições de ensinar História, fazendo seus alunos produzirem um certo saber histórico, já podemos concluir que, uma vez que não formamos um pesquisador, estamos muito 
distantes de alcançarmos êxito em relação ao "professor ideal" (VILLALTA, 1992/3, p. 228-9).

Longe de ser um caso isolado na ampla bibliografia sobre o tema, o ensaio de Villalta resume admiravelmente bem uma questão recorrente entre os proponentes da renovação: o alegado divórcio entre ensino e pesquisa, entre transmissão e produção do conhecimento. Ainda que aqui se discorde da maioria de seus argumentos, o autor faz um diagnóstico dramático de um problema que acometia seja a formação do futuro pesquisador - dada a falta de oportunidade para realizar uma iniciação científica, um mestrado ou um doutorado -, seja a do futuro docente, em razão da precariedade em que se davam os estágios supervisionados de prática de ensino. No entanto, o quadro sombrio por ele traçado está fora de lugar, pois corresponde a uma realidade de, no mínimo, duas décadas antes. O que está embutido em sua análise é um programa de ação, ao eleger a fusão entre ensino e pesquisa como solução para a alegada precariedade das práticas docentes. O resultado é que Villata (1992/3, p. 231) perde de vista não apenas a importante distinção entre os dois âmbitos, como obscurece o sentido de um e de outro nessa sedutora imagem de um professor-pesquisador: "O aluno, aprendiz da pesquisa e da arte de ensinar, confronta teoria e realidade, experimenta e aprende a ensinar o conhecimento histórico fazendo a História, estabelece a junção entre teoria e prática. Quem sabe aqui estará nascendo 'o professor ideal'”.

Exemplos como a tentativa de Villata de encontrar um professor ideal poderiam ser multiplicados, muito embora não seja o caso para os propósitos ora perseguidos. O conjunto até aqui apresentado pretendia mostrar que os argumentos utilizados pelos praticantes da Nova História não podem ser os mesmos que os proponentes da renovação do ensino de História encontram para fundamentar ações pedagógicas. Isso não se deve apenas ao fato de a História não poder ser reduzida a uma pedagogia da História, mas à premissa de que essa disciplina acadêmica não se confunde com a História enquanto disciplina escolar.

Pode-se objetar que a ausência de fronteira epistemológica entre as ciências é saudável; que se não fosse por ela não haveria trabalhos como os de Ginzburg, Darton, Chartier, Burke e Ladurie, enfim; ou que, na verdade, o futuro nos reserva uma espécie de paideia grega em que só haverá o conhecimento, pouco importando ser ele sociológico, matemático ou antropológico. Restaria saber como essa suposta paideia enfrentaria o problema do campo disciplinar estritamente escolar, que veio se configurando, tal qual o campo científico, muito lentamente, geração após geração, desde meados do século XIX no 
Brasil, ${ }^{164}$ com o fito de iniciar jovens em tradições públicas escolares. A esse respeito, sublinha Chervel (1990, p. 220):

A historiografia do ensino deu crédito à idéia de que a disciplina é a mesma coisa que essa mensagem que um adulto transmite às crianças, a disciplina não constituindo senão a culminação de um longo processo que acabou por colocar crianças e disciplinas frente a frente. A história das disciplinas escolares não a confirma.

Para Chervel, os saberes escolares se constituem em entidades culturais próprias, criações didáticas originais, o que o leva a recusar a imagem da mímesis da prática historiográfica em sentido estrito ou mesmo de um aluno como "mero receptor de informações e visões de mundo do outro", conforme sublinhou Iokoi (1984, p. 112). Os proponentes da renovação, entretanto, em vez de procurarem compreender os meios pelos quais se criam hábitos originais nas práticas de ensino, mimetizaram a operação historiográfica, como se o bom ensino fosse tão somente uma questão de método e não uma arte prática nascida no âmbito da cultura escolar e que enfrenta desafios éticos e políticos que não são análogos aos desafios presentes na teoria e na prática historiográficas.

À primeira vista, pode-se dizer que a crise na ciência histórica que Dosse expôs em $A$ História em migalhas foi extremamente profícua, pois a História saiu dela revitalizada talvez nunca tenha gozado de tanto prestígio como nas duas últimas décadas. É evidente, porém, que nem tudo se pode comemorar nessa reviravolta historiográfica, pois um consenso demasiado começa a tomar ares de doutrina, de ortodoxia. Por isso é que no debate historiográfico há polêmicas candentes que opõem os historiadores. Mas, convém insistir, esse debate se dá nas redes do discurso científico, dentro de cânones próprios à historiografia, de modo que está em perfeita harmonia com aquilo que espera de um debate dessa natureza.

O problema é quando os mesmos argumentos que os historiadores utilizam - quer para fundamentar suas opções teórico-metodológicas, quer para refutar as do adversário - são transpostos para o escorregadio terreno das Ciências da Educação. Ou seja, quando os educadores que se ocupam em refletir sobre o ensino de História absorvem aquele vocabulário com o propósito de prescrever práticas educativas, as fronteiras começam a desaparecer ou a se tornarem indistintas.

Nesse sentido, a oficina da História opera uma transposição indevida não apenas dos produtos - o que poderia ser o alvo -, mas fundamentalmente dos processos que regem a atividade do historiador profissional. Adalberto Marson (1984, p. 39, grifo nosso), uma voz

${ }^{164}$ A esse respeito, ver, por exemplo, MATTOS, 2000; BITTENCOURT, 1990. 
dissonante entre os proponentes da renovação, já indicava um caminho profícuo para a mudança ao se questionar sobre a possível identidade entre historiadores e professores de História:

A esta altura, alguém poderia interpelar: mas o que têm a ver essas conversas "epistemológicas" com o processo educativo que se desenrola nas salas de aula? Em que medida os problemas surgidos na prática do historiador têm alguma relação com a prática tão diferente do professor de história?

Em sua resposta, Marson identificava um vocabulário comum que incluía uma série de conceitos como processo, desenvolvimento, estrutura e conjuntura, consciente e inconsciente, externo e interno, influência, reflexo, crise, vazio, síntese, bem como certos princípios a eles relacionados: integração, adequação, causalidade, generalização, objetividade e utilidade. Recusava, sensatamente, o debate sobre o estatuto científico da História, preferindo discutir a validade dos critérios de racionalidade da investigação histórica. ${ }^{165}$

$\mathrm{O}$ autor sugere que os professores acabam lidando com os produtos finais ${ }^{166}$ de uma atividade científica e que, ao fazê-lo, utilizam-se (ou poderiam utilizar-se de forma mais cuidadosa e sistemática) de alguns procedimentos análogos aos dos historiadores. Assim, o que ficava indicado, em 1984, como um possível programa prático de ação pedagógica não era a constituição de uma oficina de História, mas uma nova maneira de o professor enfrentar a memória histórica que era produzida na universidade e que, direta ou indiretamente, abrangia a maioria dos materiais didáticos à sua disposição. Como enfrentar a constituição dos temas que sancionava a maior parte dos livros? Como enfrentar a memória histórica, digamos, dominante? Valendo-se dos procedimentos há pouco indicados a fim de problematizar os temas, a periodização ou mesmo as interpretações dos historiadores ou autores de livros. Em momento algum Marson propõe que se abandone o livro didático sugestão comum entre muitos dos proponentes da renovação - ou que o aluno seja transformado num historiador mirim. Entretanto, como afirma Cordeiro (2000, p. 135),

[...] embora muito citado [pelos proponentes da renovação], esse artigo de Marson não parece ter sido suficientemente compreendido, pois as referências a ele costumam ser feitas para justificar algumas afirmações de princípio do movimento que então se configurava quanto à renovação do

\footnotetext{
${ }^{165}$ Hayden White (1994) e Paul Veyne (1983) sustentam posição contrária a essa. Entre aqueles que defendem a validade dos critérios de racionalidade histórica, ver: CARR, 1996; FEBVRE, 1974; SCHAFF, 1974.

166 "Este [o professor] acaba lidando com os resultados finais do pesquisador, não importando o atraso de tempo em que isso se dê, pois constitui a 'realidade histórica' de suas aulas através da historiografia, em casos raros, e dos manuais didáticos, mais freqüentemente, que derivam das interpretações. Essencialmente é o mesmo objeto histórico: construído no passado pelo pesquisador e, em seguida, transformado em produto educacional como algo provido de sentido e significado [...]" (MARSON, 1984, p. 43).
} 
ensino de História, particularmente no que diz respeito à intenção de associar ensino e pesquisa no âmbito dos cursos de História de $1^{\circ}$ e $2^{\circ}$ graus.

Pode-se objetar que o que subjaz na oficina da História, ao contrário do que aqui se pretendeu argumentar, é o fato de ela se ter mostrado profícua; que o ensino de História verdadeiramente vive uma fase auspiciosa, o que poderia ser atestado pelo crescente número de publicações relacionadas ao tema; que nelas se encontram relatos de práticas exitosas que lançam mão dos mais variados documentos, estratégias e linguagens, como estudos de meio, uso de narrativas fílmicas, canções populares, crônicas, contos da literatura e visitas a museus; que o ensino de História hoje já se sente capaz de realizar o que em 1974 a historiografia apontava como nova possibilidade de estudos perante novos objetos, novos problemas, novas abordagens; que tais publicações já anunciavam as possíveis potencialidades de um currículo pós-moderno, de uma história do cotidiano, da história do vencido, da história das representações e do imaginário coletivo, temas e abordagens em consonância, portanto, com a mais renovada historiografia.

A objeção, de resto, não seria desmedida, pois o que por vezes se vê em tais encontros são relatos de professores apontando o dinamismo e a transformação que já estariam em curso nas salas de aula e que deveriam ser tomados como fatos dignos de nota. Contra essa maneira de ver as coisas pode-se sustentar que o ensino de História corre o sério risco de se ver transformado numa História em migalhas, conforme a advertência de Dosse. É estranho que a bibliografia de propostas curriculares de História - Proposta da CENP (Cordenadoria de Estudos e Normas Pedagógicas), de 1986 e 1992, Parâmetros Curriculares Nacionais, de 1998 -, veem-se desfilar tanto a nova historiografia francesa, quanto a história social inglesa, notadamente a obra de E. P. Thompson, sendo que um historiador da envergadura de Dosse encontra-se aí ausente. Por que tamanho silêncio em torno de uma das poucas obras ${ }^{167}$ que se propôs a discutir os limites da nova historiografia? Por que abandonar um importante interlocutor do debate sem antes confrontar a consciência histórica daquele autor?

Ora, e quais eram os pontos centrais da crítica de Dosse? Um deles consistia justamente em questionar a tomada da Nova História como a legítima herdeira dos Annales, uma vez que os fundadores tinham no horizonte a possibilidade de empreender uma história global, uma síntese integradora que os adeptos da Nova História haviam abandonado. Outro

${ }^{167}$ Ver também Espaces Temps - Refléchir lês Sciences Sociales (publicação do CNRS, n. 29/30, $2^{\circ}$ trimestre de 1985). Na ocasião, a revista promoveu um debate sobre a historiografia francesa e reuniu diversos historiadores, como Pierre Vidal-Naquet; Antoine Prost, Jean Chesneaux, Pierre Vilar, Alain Guerreau, François Bedarida, Jean Bouvier, Catherine Coquery-Vidrovitch, Immanuel Wallerstein, contra uma corrente dominante do pensamento historiográfico representado pelos adeptos da Nova História. O já mencionado número 23 da Revista USP, de 1994, traz um Dossiê Nova História, relativizando também as conquistas dessa nova historiografia. 
ponto, agora comum entre fundadores e a atual geração, é o de que, ao rejeitarem a herança positivista de uma história eminentemente política, assentada na curta duração dos eventos, acabaram enredados numa recusa do político, optando - a exemplo de O Mediterrâneo, de Braudel - por uma história de longa duração despolitizada. ${ }^{168}$

\subsection{A oficina de História à imagem do cavalo de Troia}

No capítulo anterior, ressaltou-se o espanto de Lefort quanto à recusa de certo ideal humanista de educação na França de fins dos anos 1970. Também o historiador francês Jacques Le Goff mostrava certo desconforto com o ensino de História dos liceus franceses, que àquela altura passava por reformulações. Numa mesa-redonda realizada em abril de 1977 em Paris, promovida pela revista Megazine Littéraire e composta pelos mais destacados representantes da nova historiografia francesa, ${ }^{169}$ Le Goff se pronunciou sobre a proposta que os liceus franceses estavam levando adiante em torno da história temática:

Se emiti algumas reservas a respeito da introdução da História por temas no ensino secundário, não foi, evidentemente, em relação ao princípio em si. Mas é preciso ver qual é o discurso escolar sobre o tema, e a mim parece que é o velho discurso. Existe um certo progresso quando se faz uma história narrativa desde a carroça ao avião supersônico. Mas se é, em primeiro lugar, uma História que, longe de ser a dos possíveis e da liberdade na História de que falava Veyne, se torna ao contrário, uma história mais determinista que nunca, que dá a entender que se devia forçosamente passar da carroça ao barco a vapor, ao comboio, ao automóvel e ao avião supersônico, receio que se tenham tornado as coisas ainda piores do que estavam, na medida que o conteúdo deste ensino tem seduções óbvias e diminui ainda mais o espírito crítico dos alunos. Todos os que aqui então saudaram a entrada de novos objetos na História: a História Nova pode fazer-se através do estudo de um objeto a partir do qual toda a História de uma sociedade se desmonta aos nossos olhos. Mas o que eu noto nesta História temática, tal como ela se esboça, é uma História que se encerra no tema e que não explica por que é que a carroça e o automóvel apareceram, e como isso se inscreve na História geral das sociedades. É uma História difícil de fazer, e se a História temática se fizesse assim, então eu diria "bravo"! (LE GOFF et al., 1986, p. 14-5, grifos nossos)

Também presente à mesa-redonda, o historiador Michel de Certeau levantou sérias objeções aos manuais didáticos franceses:

\footnotetext{
${ }^{168}$ Cf. SALIBA, 2003, p. 20.

${ }^{169}$ Estavam presentes no debate os historiadores Jacques Le Goff, Emmanuel Le Roy Ladurie, Georges Duby, Michel de Certeau, Paul Veyne, Philippe Ariès, Pierre Nora e Michel de Certeau.
} 
[...] o manual fala da História, mas não mostra a sua própria historicidade. Através desse déficit metodológico, impede ao estudante a possibilidade de ver como tudo se origina e de ser ele próprio produtor de História e de historiografia. Impõe o saber de uma autoridade, quer dizer, uma nãoHistória. Ao nível dos manuais há, pois, um grande trabalho a fazer para introduzir o estudante, como ator, na cidade historiográfica. Então o manual poderia ser o cavalo de Tróia de um fazer da História e de um fazer a História. (LE GOFF et al., 1986, p. 13, grifos nossos)

O autor não poderia vislumbrar o impacto que essas palavras - sobretudo em relação ao ingresso na cidade historiográfica - produziria entre alguns de seus leitores brasileiros. Como sublinha Arendt, a epopeia e, depois dela, a tragédia atualizavam um episódio mítico, refaziam certa consciência crítica do mundo, da polis, quando a cidade se fazia teatro - a mais política das artes, segundo ela - e tomava a si como objeto de representação e crítica diante do público de cidadãos. O clímax da epopeia, convém lembrar, é a catarse, quando o herói se reconcilia com a realidade - como Ulisses ao ouvir a história de seus feitos e sofrimentos por Demódoco, o narrador cego da corte dos feácios.

A metáfora sugerida por Certeau acabou sendo apropriada de forma literal pelos proponentes da renovação do ensino de História e aplicada não somente à produção de livros didáticos, mas também às práticas docentes. Nesse sentido, a Nova História literalmente invade o âmbito escolar como solução para as mazelas do ensino, e não como uma fonte inspiradora que resguardaria a devida fronteira entre a História como disciplina acadêmica e a História como disciplina escolar, conforme Marson já havia sublinhado em 1984.

É evidente que a crítica de Certeau não é destituída de significado. Pode-se presumir que os manuais franceses, tal como os brasileiros, precisassem de uma renovação diante das novas pesquisas no campo da História. Talvez, porém, a metáfora do cavalo de Troia seja inadequada para seu propósito. Tomada literalmente (como foi o caso) e convertida num programa de ação pedagógica, fez com que o presente de grego não apenas cruzasse o Atlântico, mas derrubasse a fronteira entre a universidade e a escola.

Não se podem negligenciar os efeitos retóricos daquela mesa-redonda entre renomados historiadores. A guerra que se travou contra os saberes docentes e suas experiências pedagógicas com o ensino só arrefeceu quando professores e alunos entraram de fato na cidade historiográfica para "serem eles próprios produtores de História e de historiografia", como imaginara metaforicamente o historiador francês. O que se deixou pelo caminho nessa luta contra a experiência docente dos professores de História? De acordo com Souza (2000, p. 17), 
Há uma dissociação fundante, que tem peculiaridades brasileiras, entre a memória e a educação. A transformação de descrições teóricas [...] em práticas pedagógicas, apoiadas na autoridade de um discurso percebido como "científico", "natural" e "moderno", tem levado à aceitação acrítica de teorias, muitas vezes na sua versão pasteurizada, para o ensino de professores. Tomando a educação como um campo de aplicação, estabeleceu-se uma confusão entre o "prático" e o "empírico", servindo a ciência como "teoria" e a prática educacional como "empiria" e a justaposição equivocada do discurso científico a um discurso técnico, retórico e prescritivo [...]. A percepção da educação como aplicação de ciências levou à idéia de que o olhar sobre a experiência docente necessariamente é objeto de crítica, e por crítica entende-se uma desqualificação preliminar.

Assim, aqueles que se confirmavam renovadores contribuíram para formar um consenso de que tradicional é sinônimo de ruim e renovado equivale a bom. Renovadas, então, seriam a Nova História e a pedagogia que dela deriva. Ora, como um professor de História pode se sentir investido de autoridade (nos termos em que Arendt a define) se sua prática diária da docência - que presumivelmente encontra formas de se refazer e não está imune a equívocos e limitações de ampla ordem - é identificada como ultrapassada? Que autoridade ainda é possível conservar se a oficina da História foi deixada na porta da escola, num cavalo majestoso conduzido por Michel de Certeau e outros representantes da Nova História?

Como a narrativa ainda é um modo de fornecer significado e sentido às ações humanas - "Todas as dores são suportáveis se as incluirmos numa história ou contarmos uma história acerca delas" (DINESEN, apud ARENDT, 1991, p. 125) -, o consenso renovador nega aos professores a arte de contar histórias e aos alunos o prazer de ouvi-las. A alegoria de Sheherazade, que conta histórias por mil e uma noites - tempo infinito -, renovando a cada sessão a curiosidade do ouvinte, não pode ser admitida em razão de uma passividade que lhe é atribuída, por não desvendar ao aluno os bastidores de onde aquela história se originou, os truques de ilusionismo - nas palavras de Miceli (1988) - que teriam sido operados para que a narrativa encontrasse um lugar ao sol no território contestado do ensino de História. ${ }^{170}$

Nada mais sintomático do transporte efetuado pelos renovadores do que essa imagem utilizada por Miceli, na qual os professores de história são equiparados a mágicos. A diferença é que seus truques de ilusionismo, em vez de provocarem espanto e admiração nos alunos - e convém lembrar que todo mágico que se preze jamais revela suas estratégias -,

\footnotetext{
${ }^{170}$ É interessante notar que boa parte das tentativas do mercado editorial de livros didáticos e paradidáticos de estabelecer um paralelo entre História e literatura, História e cotidiano, sofreu severos ataques do consenso renovador. Ver, por exemplo, GLEZER, 1984; ZAMBONI, 1992/3. Uma voz dissonante pode ser encontrada em SILVA, 1985.
} 
fizeram deles impostores, por não desvelarem aos alunos os segredos por trás de suas histórias. O comentário de Arendt (2010a, p. 362) sobre a relação entre o desvelamento da verdade e o processo de experimentação (o experimento em si) ao examinar a inversão, na era moderna, entre contemplação e ação cabe inteiramente aqui:

Realmente, nada poderia ser menos digno de confiança para adquirir conhecimento e aproximar-se da verdade que a observação passiva ou a mera contemplação. Para ter certeza, tinha-se de assegurar-se e, para conhecer, tinha de agir. A certeza do conhecimento só podia ser atingida mediante dupla condição [...] que o conhecimento se referisse apenas àquilo que o próprio homem havia feito [...] e [...] que [...] fosse de tal natureza que ele só pudesse ser testado mediante mais agir.

Assim, os renovadores negam aos professores a capacidade de dizer, de contar histórias. Segundo eles, para dizer é preciso que antes se revele qual foi o modus operandi para se chegar àquilo que está sendo dito - como pretenderam os críticos de Arendt em relação à obra Origens do totalitarismo. Ora, ali se tratava de uma crítica entre iguais, no interior de um debate acadêmico e público. Daí a imaginar que é preciso ensinar o método do historiador aos alunos, para que eles então produzam a própria história, existe um enorme abismo. A narrativa, enfim, salvo engano, parece sofrer novo exílio. 


\section{A narrativa cativa}

No início deste trabalho, sugeriu-se que o horror totalitário colocou Hannah Arendt diante de um problema de compreensão e de linguagem. Tal problema se expressava numa inadequação das categorias herdadas para compreender, ajuizar e, por fim, narrar as ações dos movimentos totalitários. A partir do silêncio de Auschwitz, insinuou-se a ideia de um exílio da narrativa. ${ }^{171}$ Atravessada por um sentimento que beira o trágico, a pesquisa se encerra temendo que a narrativa, por distintas razões cujas consequências não são animadoras, esteja a sofrer novo exílio.

Para Arendt e a geração que viveu aqueles tempos sombrios, o exílio da narrativa foi um ato involuntário. Surgiu como reação à tomada de consciência dos experimentos inimagináveis praticados nas fábricas de extermínio. Voluntária, entretanto, foi a tentativa de sair da mudez, consubstanciada no gesto político de não se curvar a uma realidade sem precedentes, mas de resistir pela via da compreensão e do juízo, muito embora o horror dos campos não possa "ser inteiramente alcançado pela imaginação justamente por situar-se fora da vida e da morte" (ARENDT, 1989, p. 494).

Tal qual Tucídides, Arendt assumiu o lugar de um historiador em exílio. Tomou para si, como pária consciente, a responsabilidade de compreender, narrar e trazer à luz pública algum significado para aquele trágico e inédito evento, ainda que o horror totalitário não possa ser inteiramente compreendido e narrado. O fundamental é que a narrativa de Arendt significou uma tentativa de reconciliação com o mundo em que foi possível a aparição do totalitarismo. Nesse sentido, o narrar transforma-se num compromisso ético com aqueles que viveram tempos sombrios, compromisso este que toma forma numa narrativa do exílio: a escrita como regresso, senão à pátria natal, a uma identidade que é parte da pluralidade dos homens e que esteve ameaçada de ser eliminada do mundo.

Vários governos do mundo têm hoje de lidar com a questão dos refugiados, aqueles que, por distintas razões - em geral, guerras civis que assolam seus países -, são obrigados a abandonarem suas casas e a errarem pelo mundo, vagabundos à moda de Ulisses, como dissera Arendt em relação aos judeus. Após o alargamento do campo de pesquisa do historiador, o legado de Arendt aponta, como uma bússola, um lugar possível para o trabalho

\footnotetext{
171 "Nuestro tiempo y nuestro espacio no pueden ser pensados sin Auschwitz, pero al mismo tiempo no pueden quizá - ser pensados en Auschwitz, porque Auschwitz ha roto nuestro lenguaje, el lenguaje en el que radicalmente se transmitían las experiencias" (BÁRCENA, 2000, p. 225).
} 
do historiador atual: ali, em meio aos refugiados, resgatando a pluralidade daqueles sujeitos sem voz, sem pátria, sem destino e cheios de histórias para contar.

A questão da pluralidade vincula a obra de Arendt à de Primo Levi quanto ao problema do direito à memória daqueles que sobreviveram ao Holocausto e da própria impossibilidade da constituição de uma narrativa. Em A trégua (2010, p. 77, grifo nosso), obra em que Levi narra seu retorno de trem à Itália após a libertação de Auschwitz, ele relata um episódio envolvendo o amigo César, que o convidara a acompanhá-lo ao mercado:

Aceitei-o não só por amizade, e para fugir do tédio do campo, mas sobretudo porque assistir às empresas de César, mesmo as mais modestas e triviais, constituía uma experiência única, um espetáculo vivo e um fortificante, que me reconciliava com o mundo, e reacendia em mim a alegria de viver que Auschwitz apagara.

É evidente que as experiências, as perdas e os sofrimentos que Arendt e Levi viveram pelo fato de serem judeus são distintos. A despeito dessas diferenças, porém, há algo que os une: a fé inabalável na crença de que o mundo deve persistir, de que laços de amizade possam se constituir, de que os homens só existem no plural, de que eles nascem com o dom de começar, interromper, transformar. Mais do que isso, acreditam ambos que, ao agirem, os homens criam condição para a lembrança, ou seja, para a história. A obra de Levi é um testemunho de que "todas as dores são suportáveis se as incluirmos numa história ou contarmos uma história acerca delas" (DINESEN, apud ARENDT, 1991, p. 125). O suicídio de Levi, contudo, mostra que até mesmo o poder redentor da narrativa - para usar a expressão de Benhabib (1994) - e a busca da reconciliação com um mundo em que Auschwitz foi possível encontram seus limites. A lição que se pode retirar daí é a de que não se deve privar nossos alunos, esses recém-chegados, do direito às histórias, a fim de que eles possam se situar num mundo que os precede e que perdurará para além de suas vidas individuais.

Nesse sentido, a metáfora da oficina da História foi aqui empregada como um recurso que visou a acentuar e clarificar certos pressupostos cristalizados na pretendida transposição do fazer do historiador para as práticas de ensino. Por vezes, só a caricatura - certo realce que exagera os traços - expressa claramente um modo de analisar as coisas. O que se quis realçar é que, a despeito das boas intenções que animavam os proponentes da renovação, a oficina da História se volta contra a própria história em razão da ênfase desmedida conferida aos aspectos metodológicos do ensino.

Não é pelo obstinado desejo de ofertar aos alunos técnicas de manipulação de documentos - impressos num livro didático ou previamente selecionados pelo professor - que 
o ensino de História cumprirá seu imprescindível papel de legar um sentido para a experiência humana no mundo. Isso só se torna realizável com a transmissão deliberada de uma herança simbólica, que, no caso da História, assume a feição de uma narrativa, da qual, como um poeta cego e imparcial, o professor - ao menos como um horizonte a ser perseguido ou dos possíveis, como diria Le Goff - é o legítimo portador. Porque o sentido de uma história é indissociável daquele que a narra, isto é, para que algo possa ser contado, é necessário que alguém o faça. E o professor de História o faz na presença de seus alunos e na esperança de implicá-los nas histórias que relata. Mas onde foi parar o quem das histórias contadas entre os proponentes da renovação do ensino? Quando se transpôs o processo que rege a atividade do historiador profissional para as práticas de ensino, os meios se tornaram mais significativos do que o conteúdo das histórias, e sua finalidade (o produto da ação do aluno sobre os documentos) passou a ser mais relevante do que o sentido que elas possam ter.

Como sublinha Arendt (1992, p. 285),

Nenhum mundo humano destinado a perdurar após o curto período de vida dos mortais seria capaz de sobreviver sem que os homens estivessem propensos a fazer aquilo que Heródoto foi o primeiro a empreender conscienciosamente - a saber, légein ta eónta, dizer o que é. Nenhuma permanência, nenhuma perseverança da existência podem ser concebidas sem homens decididos a testemunhar aquilo que é e que lhes aparece porque é.

É evidente que um professor de História também é um ator político e uma testemunha de seu tempo, de modo que a ele não se pode negar que emita um juízo político sobre o mundo. Diante de seus alunos, no entanto, seu compromisso não é o de construir o futuro, mas sim o de mostrar como o mundo veio a ser o que é. Assim, inadvertidamente, os proponentes da renovação negaram ao professor de História seu bem mais precioso: o direito à palavra: "o ensino de História tem se constituído em solo fértil para a memorização, a repetição, o monólogo do professor, um espaço propício para a idéia de saber pronto e acabado, que resta apenas transmitir” (STEPHANOU, 1998, p. 19-20).

Não custa lembrar que entre os mais assíduos correspondentes de Arendt figurava um professor - Jaspers - e que a palavra por ela escolhida para definir essa amizade-diálogo em torno das coisas do mundo foi claridade. Ora, a um professor não é possível clarificar - seja o que for -, ensejar compreensão ou convidar o aluno a ter apreço pelo mundo sem "légein ta eónta, dizer o que é”. Como sublinha Veyne (1987, p. 121-3, grifo nosso),

É vão opor uma história narrativa a uma outra que teria a ambição de ser explicativa; explicar mais é contar melhor, e de qualquer modo não se pode 
contar sem explicar; as 'causas' de um fato, no sentido aristotélico, o agente, a matéria, a forma ou o fim, são, na verdade, os aspectos desse fato.

Arendt não supôs que por trás dos fatos pudesse haver algum fenômeno inexorável ou capaz de determinar algo. Todavia, não fez nenhuma profissão de fé contra os fatos, como sugere a proposta de uma história temática para o ensino de História. Ela certamente compartilharia da crítica que os adeptos dos Annales e da Nova História fizeram ao historicismo, mas não do exagero a que eles chegaram. Nesse sentido, antecipou o que na historiografia se nomeou ora como um retorno aos fatos (NORA, 1988), ora como um ressurgimento da narrativa. Ao contrário, ela enfatizou, ao longo de sua obra, que caberia ao poeta e ao historiador remediar o caráter frágil da ação por meio de uma narrativa que fixasse os fatos dignos de perdurarem.

Mas ela também acentuou que fatos e eventos, mesmo quando reificados, não estão imunes a toda sorte de falsificações e mentiras. O caso Dreyfus e a maneira como Arendt o reconstrói em Origens do totalitarismo são um claro exemplo disso. Não é à toa que o capítulo dedicado ao assunto faz lembrar tanto o proêmio de Herótodo, quanto o de Tucídides: “Aconteceu na França em fim de 1984. Alfred Dreyfus, um oficial judeu do Estado-Maior francês, foi acusado e condenado por espionagem em favor da Alemanha" (ARENDT, 1989, p. 111). A trama narrativa que Arendt constrói a partir dessa introdução constitui um claro exemplo do que significa buscar imparcialidade no julgamento de um fato histórico.

Não seria o caso de resgatar aqui o evento em torno de Dreyfus, mas apenas de assinalar algumas questões que perpassaram este trabalho, vinculando-as ao ensino de História. Ainda que na réplica a Voegelin Arendt tenha afirmado que rompera conscientemente com a tradição do sine ira et studio (sem cólera, nem parcialidade), é preciso relativizar tal rompimento. Na verdade, o rompimento existe, mas não cobre todo o espectro da análise arendtiana empreendida em Origens do totalitarismo; ele incide especialmente sobre o caráter sem precedentes das fábricas de extermínio e da descartabilidade, da superfluidade e da indignidade a que os confinados nos campos estavam sujeitos antes mesmo de serem eliminados.

A análise de Arendt sobre o caso Dreyfus toma como referência nesse fato seu significado político. Não se trata da aplicação pura e simples da imparcialidade homérica, nem da praticada pelos historiadores antigos, mas ambas ecoam no texto arendtiano de forma pungente, atestada pela presença da polifonia de vozes que se ergueram contra ou a favor de Dreyfus ao longo do processo e depois dele, evocando claramente a forma antagônica com que Tucídides apresenta os discursos de alguns atores políticos na narrativa da Guerra do 
Peloponeso. O mesmo se poderia dizer quanto à trama narrativa de Sobre a revolução, em que as fontes primordiais de Arendt são os discursos dos revolucionários franceses ou dos fundadores da república americana.

Imparcialidade, convém ressaltar, não é sinônimo de neutralidade. Mas a posição de Arendt não se explicita em momento algum. A autora seleciona o caso Dreyfus precisamente por ver nele um fato paradigmático do desenvolvimento de algo muito mais amplo: o antissemitismo europeu (ora, aqui ela poderia estar antecipando a micro-história de Carlo Ginsburg, ao construir uma ampla síntese a partir da particularidade de um evento singular), um dos elementos fundamentais que se cristalizaram no totalitarismo. Antes, a análise faz emergir as diversas vozes em disputa em torno do caso em pauta, que aparecem em defesa de seus pontos de vista de forma que o leitor vai tomando conhecimento da posição assumida pela família do acusado; pelo advogado de Dreyfus (Démange); pelo Parlamento Francês (que em 1998 contava com apenas dois partidários de Dreyfus); pelos generais classistas do exército francês e pelo coronel Picquard, seu antagonista; pela imprensa católica francesa, bem como pela imprensa radical e socialista; pelo Papa Leão XIII; e pelos dreyfusards (os partidários de Dreyfus), como Zola, Clemenceau, Lazare, Picquard, Anatole France e o historiador Gabriel Monod. A trama montada por Arendt é de tal natureza que o próprio leitor se sente desejoso de tomar uma posição e, ao final, proclamar seu juízo.

Enfim, submetendo a própria narrativa de Arendt às suas reflexões teóricas posteriores, talvez se possa dizer que ela interpretou o caso Dreyfus a partir de diferentes pontos de vista, tornando presentes em sua mente as posições dos que estavam ausentes, isto é, representando-os. ${ }^{172}$ Sair em visita a outras perspectivas significa alargar o pensamento como forma de preparar a imparcialidade do juízo. E a faculdade que possibilita esse alargamento é a imaginação:

Mnémosine, a Memória, é a mãe das Musas, e a rememoração, a mais
freqüente e também a mais elementar experiência de pensar, tem a ver com
coisas que estão ausentes, que desapareceram dos meus sentidos. No entanto,
o ausente que é convocado e tornado presente ao meu espírito - uma pessoa,
um acontecimento, um monumento - não pode aparecer da maneira que
apareceu aos meus sentidos, como se a recordação fosse uma espécie de
feitiçaria. Para aparecer unicamente para a minha mente, tem primeiro que
ser tornado não sensível, e a capacidade para transformar objetos-dos-
sentidos em imagens é chamada "imaginação" (ARENDT, 1999, p. 97-8).

172 O trecho a partir do qual se fez a paráfrase está no ensaio Verdade e política (ARENDT, 1992, p. 299): "Formo uma opinião considerando um dado tema de diferentes pontos de vista, fazendo presentes em minha mente as posições dos que estão ausentes; isto é, eu os represento". 
É fundamentalmente com essas coisas ausentes que lida um professor de História. E é com isso em vista que o presente trabalho lança o desafio futuro de se pensar sobre as implicações desta instigante faculdade humana: a imaginação. Cultivá-la entre os alunos talvez seja algo imprescindível num mundo em que a enxurrada de informações e estímulos de toda sorte, especialmente os visuais, parecem congestionar o pensamento. Num ensaio sobre o uso e o consumo das imagens, Saliba (1997, p. 122, grifo nosso) adverte que o historiador,

Artífice da palavra num mundo que a despreza [...] se vê ameaçado pela pecha de antiquário. Mesmo na figura do professor, profissional treinado na grafosfera, vê-se desqualificado e desconfortável neste mundo permeado pela videosfera. Assistimos, no caso da História, a uma espécie de regressão aos procedimentos internos da obra historiográfica, reduzindo, assim, toda a questão da síntese histórica às vicissitudes da prática discursiva do historiador, seja ela, narrativa, hermenêutica ou analítica.

Contra essa "regressão aos procedimentos internos da obra historiográfica" - aqui representada na crítica à oficina de História e à apropriação enviesada da metáfora do cavalo de Tróia de Certeau -, Saliba (1997, p. 124) evoca o personagem Carlitos, de Chaplin, cujas atitudes

[...] são sempre cômicas, talvez pela sua total falta de obstinação face à dura oposição do mundo dos objetos ou das engrenagens mecânicas. Vigas que despencam sobre a sua cabeça, cadeiras e mesas que se quebram, engrenagens e ferramentas que se movimentam - a matéria, para Carlitos, parece possuída de uma animosidade hostil.

A oficina de História goza hoje de profunda solidez. Chancelada nos Parâmetros Curriculares Nacionais sob o título de história temática, representa a recusa à ideia de uma história universal. Os livros, de forma geral, não vêm acompanhados de manuais que nos instruam sobre o modo como se deve lê-los. Já as máquinas que compramos, sim, pois manipulá-las pode ser perigoso para o usuário ou consumidor. Entretanto, os livros didáticos de História são acompanhados de esmerados manuais, por vezes em igual tamanho ou até maiores do que o livro propriamente dito. Talvez isso se dê porque, ali, o professor já não encontra histórias, mas uma oficina "possuída de uma animosidade hostil”.

Ao final de uma resenha sobre A condição humana, de Arendt, McCarthy (1967, p. 167) assim resumiu o que lhe parecia ser a intenção de Arendt com a obra: "Es como se estuviese llenando un baúl a toda prisa con todo lo valioso, con las bagatelas y las curiosidades de la experiencia humana, con la esperanza de que algo sobreviva". Nós, professores de história, somos os guardiões desse baú. Arendt talvez ficasse satisfeita se 
pudéssemos levá-lo para a sala de aula, abri-lo aos alunos e, para cada tesouro ali guardado, contar uma história. A narrativa cativa. 


\section{Referências bibliográficas}

ABREU, Martha. Escrevendo filmes. Revista de História da Biblioteca Nacional, ano 4, n. 41, p. 98 , fev. 2009.

ADORNO, Theodor W. Educação e emancipação. 2. ed. São Paulo: Paz e Terra, 2000.

ALMEIDA, Vanessa S. de. Amor mundi e educação: reflexões sobre o pensamento de Hannah Arendt. Tese (Doutorado em Educação) - Universidade de São Paulo, São Paulo, 2009.

Cortez, 2011.

Educação em Hannah Arendt: entre o mundo deserto e o amor ao mundo. São Paulo:

AMIEL, Anne. Hannah Arendt: política e acontecimento. Tradução de Sofia Mota. Lisboa: Instituto Piaget, 1997.

ARENDT, Hannah. Origens do totalitarismo. São Paulo: Companhia das Letras, 1989.

. Homens em tempos sombrios. Lisboa: Relógio D’ Água, 1991.

. Entre o passado e o futuro. São Paulo: Perspectiva, 1992.

. A dignidade da política. Rio de Janeiro: Relume Dumará, 1993a.

Lições sobre a filosofia política de Kant. Organização de Ronald Beiner, Tradução de André Duarte. Rio de Janeiro: Relume Dumará, 1993b.

Rahel Varnhagen: a vida de uma judia alemã na época do romantismo. Tradução de Antônio Trânsito e Gernot Kludasch. Rio de Janeiro: Relume Dumará, 1994.

. O conceito de amor em Santo Agostinho. Lisboa: Instituto Piaget, 1997.

. A vida do espírito (Pensar). Lisboa: Editora Piaget, 1999.

. A vida do espírito (Querer). Lisboa: Editora Piaget, 2000.

. Sobre a revolução. Lisboa: Relógio D’ Água, 2001.

$2004 \mathrm{a}$.

La tradición oculta. Tradução de. R. S. Carbó e V. G. Ibáñez. Barcelona: Paidós,

Reflexões sobre Little Rock. In: . Responsabilidade e julgamento. Tradução de Rosaura Einchenberg. São Paulo: Companhia das Letras, 2004b. p. 261-281.

. Labor, work, action (apresentação, tradução e notas de Adriano Correia). Cadernos de Ética e Filosofia Política, n. 7, p. 141-164, fev. 2005a. 
Una revisión de la historia judia y otros ensayos. Tradução de Miguel Candel. Barcelona: Paidós, 2005b.

A promessa da política. Rio de Janeiro: DIFEL, 2008a.

. Compreender: formação, exílio e totalitarismo (ensaios). São Paulo: Companhia das Letras; Belo Horizonte: Editora UFMG, 2008b.

. Sobre a violência. Rio de Janeiro: Civilização Brasileira, 2009.

- A condição humana. Tradução de Roberto Raposo, Revisão técnica de Adriano Correia. 11. ed. Rio de Janeiro: Forense Universitária, 2010a.

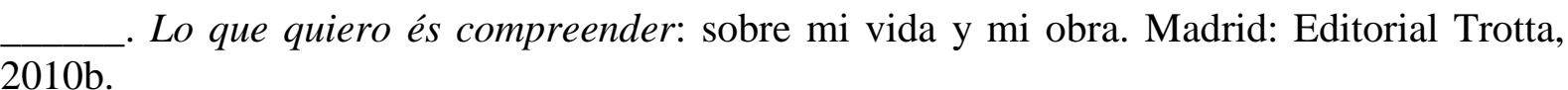

Diario filosófico: 1950-1973. Edição de Ursula Ludz e I. Nordmann, Tradução de Raul Gabás. 2. ed. Barcelona: Herder, 2011.

ARENDT, Hannah; VOEGELIN, Eric. Debate sobre el totalitarismo. Cláves de Razón Práctica, n. 124, 2002.

ARISTÓTELES. Política. 2. ed. São Paulo: Martins Fontes, 1998.

AUGUSTO, Maurício L. Quando a teoria inventa a prática: os discursos de "renovação" frente ao "ensino tradicional" de História. Dissertação (Mestrado em Educação) Universidade de São Paulo, São Paulo, 2003.

AZANHA, José Mário Pires. Democratização do ensino: vicissitudes da idéia no ensino paulista. Revista da Faculdade de Educação da USP, São Paulo, v. 5, n. 1/2, jan./dez. 1979.

. Uma idéia de pesquisa educacional. São Paulo: Edusp, 1992.

. Educação: temas polêmicos. São Paulo: Martins Fontes, 1995.

BÁRCENA, Fernando. Hannah Arendt: una filosofía de la natalidad. Barcelona: Herder, 2006.

BÁRCENA, Fernando; MÈLICH, Joan-Carles. La lección de Auschwitz. Isegoria, n. 23, p. 225-236, 2000.

BEINER, Ronald. Hannah Arendt: sobre o julgar. Ensaio interpretativo In: ARENDT, Hannah. Lições sobre a filosofia política de Kant. Rio de Janeiro: Relume Dumará, 1993.

BENHABIB, Seyla. Hannah Arendt and the redemptive power of narrative. In: HINCHMAN, Lewis P.; HINCHMAN, Sandra K. (Org.). Hannah Arendt: critical essays. Albany: Suny Press, 1994. 
La paria y su sombra: sobre la invisibilidad de las mujeres en la filosofía política de Hannah Arendt". In: BIRULÉS, Fina. Hannah Arendt: el orgullo de pensar. Barcelona: Gedisa, 2000. abr. 2007.

Con Arendt, contra Arendt. Manuel Cruz entrevista Seyla Benhabib. Letras Libres,

BENVENUTI, Erica. Educação e política em Hannah Arendt: um sentido político para a separação. Dissertação (Mestrado em Educação) - Universidade de São Paulo, São Paulo, 2010.

BIGNOTTO, Newton. Totalitarismo e liberdade no pensamento de Hannah Arendt. In: MORAES, Eduardo Jardim de; BIGNOTTO, Newton (Orgs.). Hannah Arendt: diálogos, reflexões, memórias. Belo Horizonte: Ed. UFMG, 2001a. p. 111-123.

BIGNOTTO, Newton. Origens do republicanismo moderno. Belo Horizonte: Ed. UFMG, 2001b.

BIRULÉS, Fina. La especificidad de lo político: Hannah Arendt. Valencia: Ediciones Episteme: 1985.

(Org.). El genero de la memoria. Pamplona: Ed. Pamiela: 1995.

Por qué debe haber alguien y no nadie? (Introducción) In: ARENDT, Hannah. Que es la política? Barcelona: Paidós, 1997. (Tradução parcial castellana de Rosa S. Carbó de Was ist Politik? Aus dem Nachlass. Edición de Ursula Ludz, Munique: Piper, 1996.)

(Org.) Hannah Arendt: el orgullo de pensar. Barcelona: Gedisa, 2000.

Hannah Arendt y la condición judia (Introdución). In: ARENDT, Hannah. Una revisión de la historia judía y otros ensayos. Tradução de Miguel Candel. Barcelona: Paidós, $2005 \mathrm{a}$.

Memoria, inmortalidad e historia en Hannah Arendt. In: CRUZ, Manuel; BRAUER, Daniel. La comprensión del pasado: escritos sobre filosofia de la historia. Barcelona: Herder Editorial, 2005b.

. Una herencia sin testamento: Hannah Arendt. Barcelona: Herder Editorial, 2007.

Contingencia, historia e narración en Hannah Arendt. 2009. Disponível em: <http://congresos.um.es/ahha/ahha2009/paper/viewFile/6291/6031>. Acesso em: 4 set. 2013.

BIRULÉS, Fina; CRUZ, Manuel (Orgs.) Em torno a Hannah Arendt. Madrid: Centro de Estudios Constitucionales, 1994.

BITTENCOURT, Circe M. Fernandes. Pátria, civilização e trabalho: o ensino de História nas escolas paulistas (1917-1939). São Paulo: Edições Loyola, 1990.

BOBBIO, Norberto et al. Dicionário de política. 13. ed. Brasília: Editora Universidade de Brasília, 2009. 
BODEI, Remo. A história tem um sentido? Bauru: EdUSC, 2001.

BODZIAK JR., Paulo Eduardo. Uma pérola em Kant: a recuperação do Juízo estético reflexionante Kantiano sob uma dimensão política. Cadernos de Ética e Filosofia Política, v. 17, p. 21-43, 2010.

BOTO, Carlota Reis. A escola do homem novo: entre o Iluminismo e a Revolução Francesa. São Paulo: Unesp, 1996.

BOURETZ, Pierre. Testemunhas do futuro: filosofia e messianismo. Tradução de J. Guinsburg, F. Kon, e V. L. Felício. São Paulo: Perspectiva, 2011.

BRAYNER, Flávio. Da criança-cidadã ao fim da infância. Educação \& Sociedade, ano XXII, n. 76, p. 197-8, out. 2001.

BRIGHTMAN, Carol. Um romance epistolar. In: (Org.). Entre amigas: a correspondência de Hannah Arendt e Mary McCarthy. Rio de Janeiro: Relume Dumará, 1995.

BURKE, Peter (Org.). A escrita da história: novas perspectivas. São Paulo: Editora UNESP, 1992.

A Escola dos Annales: a revolução francesa da historiografia. Tradução de Nilo Odália. São Paulo: Fundação Editora da UNESP, 1997a.

Vico. São Paulo: Editora UNESP, 1997b.

CABRINI, Conceição. O ensino de História: revisão urgente. Bauru: EDUSC, 2000.

CANOVAN, Margaret. Hannah Arendt como pensadora conservadora. In: BIRULÉS, Fina (Comp.). Hannah Arendt: el orgullo de pensar. Barcelona, Gedisa Editorial, 2000.

CARDOSO, Ciro Flamarion; VAINFAS, Ronaldo. Domínios da história: ensaios de teoria e metodologia. Rio de Janeiro: Campus, 1997.

CARR, Edward Hallet. Que é história? Rio de Janeiro: Paz e Terra, 1996.

CARVALHO, José Sérgio Fonseca de. Apontamentos para uma crítica das repercussões da obra de Paulo Freire. Cadernos de História e Filosofia da Educação, v. II, n. 4, p. 23-33, 1998.

. 'Democratização do ensino' revisitado. Educação e Pesquisa, São Paulo, v. 30, n. 2, p. 327-334, maio/ago. 2004.

. A crise na educação como crise da modernidade. Revista Educação, Especial Hannah Arendt Pensa a Educação, São Paulo, n. 4, p. 16- 25, 2007. Ltda., 2013a.

Reflexões sobre educação, formação e esfera pública. Porto Alegre: Penso Editora 
Educação: uma herança sem testamento. Tese (Livre-Docência) - Faculdade de Educação, Universidade de São Paulo, São Paulo, 2013b. (versão eletrônica)

CASSIRER, Ernst. Ensaio sobre o homem: introdução à filosofia da cultura humana. São Paulo: Martins Fontes, 1997.

CAVALCANTE, Berenice. Hannah Arendt em companhia de historiadores. In: MORAES, Eduardo Jardim de; BIGNOTTO, Newton (Orgs.). Hannah Arendt: diálogos, reflexões, memórias. Belo Horizonte: Ed. UFMG, 2001. p. 176-195.

CERTEAU, Michel de. A operação histórica. In: LE GOFF, Jacques; NORA, Pierre (Orgs.) História: novos problemas, novos objetos, novas abordagens (3 vols.). Rio de Janeiro: Francisco Alves, 1988.

CÉSAR, Maria Rita de Assis. A educação num mundo à deriva. Revista Educação, São Paulo, v. 4, p. 36-45, 2007.

CHAUÍ, Marilena. Introdução à história da filosofia: dos pré-socráticos a Aristóteles. 2. ed. rev. e ampl. São Paulo: Companhia das Letras, 2002.

CHERVEL, André. História das disciplinas escolares: reflexões sobre um campo de pesquisa. Teoria \& Educação, Porto Alegre, n. 2, p. 177-229, 1990.

CHESNEAUX, Jean. Devemos fazer tabula rasa do passado? Sobre a História e os historiadores. São Paulo: Ática, 1995.

COHN, Gabriel. Adorno e a teoria crítica da sociedade. In: ADORNO, Theodor W. Theodor Adorno (Sociologia). Organização de Gabriel Cohn. São Paulo: Ática, 1986. (Coleção Grandes Cientistas Sociais).

COLLIN, Françoise. Praxis de la diferencia: liberación y liberdad. Barcelona: Icaria Editorial, 2006.

COLLINGWOOD, Robin George. A idéia de história. Tradução de Alberto Freire. Lisboa: Editorial Presença, 1972.

CONSTANT, Benjamin. Da liberdade dos antigos comparada à dos modernos. Filosofia Política, n. 2, 1985.

CORDEIRO, Jaime F. Parreira. Memória e ensino: projetos e trajetórias do trabalho pedagógico. In: ENCONTRO PERSPECTIVAS DO ENSINO DE HISTÓRIA, 2., 1996, São Paulo. Anais... São Paulo: Universidade de São Paulo, 1996.

. A História no centro do debate: as propostas de renovação do ensino de História nas décadas de setenta e oitenta. Araraquara: FCL/Unesp, 2000.

Falas do novo, figuras da tradição: o novo e o tradicional na educação brasileira (anos 70 e 80). São Paulo: Editora UNESP, 2002. 
CORREIA, Adriano. Hannah Arendt e o conceito de progresso. In: Odilio Alves et al. (Orgs.). Origens do totalitarismo: 50 anos depois. Rio de Janeiro: Relume Dumará, 2001.

- "Sentir-se em casa no mundo": a vida do espírito (mind) e o domínio dos assuntos humanos no pensamento de Hannah Arendt. Tese (Doutorado) - Universidade Estadual de Campinas, Campinas, 2002a.

(Org.). Transpondo o abismo: Hannah Arendt entre a filosofia e a política. Rio de Janeiro: Forense Universitária, $2002 b$.

Apresentação da tradução "Labor, work, action" de Hannah Arendt. Cadernos de Ética e Filosofia Política, n. 7, p. 141-164, 2/2005.

O significado político da natalidade: Arendt e Agostinho. In: CORREIA, Adriano; NASCIMENTO, Mariangela (Orgs.). Hannah Arendt: entre o passado e o futuro. Juiz de Fora: UFJF, 2008. p. 15-34.

Apresentação à nova edição brasileira. In: ARENDT, Hannah. A condição humana. Tradução de Roberto Raposo, Revisão técnica de Adriano Correia. 11. ed. Rio de Janeiro: Forense-Universitária, 2010a.

Natalidade e amor mundi: sobre a relação entre educação e política em Hannah Arendt. Educação e Pesquisa, v. 36, n. 3, p. 811-822, 2010 b.

COUTINE-DÉNAMY, Silvie. Hannah Arendt. Tradução de Ludovina Figueiredo. Lisboa: Instituto Piaget, 1999.

CRESPIGNY, Anthony; MINOGUE, Kenneth. Hannah Arendt: a nostalgia helênica e a sociedade industrial. In: Filosofia Política Contemporânea, 1979. p. 25-32.

CRUZ, Heloisa de Faria. Ensino de História, da reprodução à produção de conhecimento. In: SILVA, Marcos A. da (Org.) Repensando a História. São Paulo: ANPUH/Marco Zero, 1984. p. 25-29.

CRUZ, Manuel. Hacerse cargo: sobre responsabilidad e identidad personal. Barcelona: Paidós, 1999

CUSTÓDIO, Crislei de Oliveira. Educação e mundo comum em Hannah Arendt: reflexões e relações em face da crise do mundo moderno. Dissertação (Mestrado em Educação) Universidade de São Paulo, São Paulo, 2011.

DISCH, Lisa. Más verdadero que los hechos: storytelling como comprensión crítica em los escritos de Hannah Arendt. Taula, quaderns de pensament: Revista del departament de Filosofia i Treball Social de la Universitat de lês Illes Balears, n. 43, 2012.

DOSSE, François. A História em migalhas: dos Annales à Nova História. Tradução de Dulce Oliveira Amarante dos Santos. Bauru: EDUSC, 2003.

DRUCKER, Claudia. O futuro da "Outra Tradição". Revista de Sociologia e Política, Curitiba, p. 205-208, 14 jun. 2000. 
DUARTE, André. Educação: entre a tradição e a ruptura. Revista Educação, Especial Hannah Arendt Pensa a Educação, São Paulo, n. 4, p. 84-89, 2007.

Pensar e agir por amor ao mundo. Revista Educação, Especial Hannah Arendt Pensa a Educação, São Paulo, n. 4, p. 6-15, 2007.

Hannah Arendt e a dimensão política do juízo reflexionante estético kantiano. Dissertação (Mestrado) - Faculdade de Filosofia, Letras e Ciências Humanas, Universidade de São Paulo, São Paulo, 1992.

O pensamento à sombra da ruptura: política e filosofia em Hannah Arendt. São Paulo: Paz e Terra, 2000.

. Hannah Arendt e o evento totalitário como cristalização histórica. In: AGUIAR, Odilio Alves et al. (Orgs.). Origens do totalitarismo: 50 anos depois. Rio de Janeiro: Relume Dumará, 2001.

Hannah Arendt e o pensamento político: a arte de distinguir e relacionar conceitos. Argumentos, Fortaleza, n. 9, jan./jun. 2013.

DUARTE, André et al. (Orgs.). A banalização da violência: a atualidade do pensamento de Hannah Arendt. Rio de Janeiro: Relume Dumará, 2004.

FEBVRE, Lucien. Combates por la historia. Buenos Aires: Editorial Ariel, 1974.

FÉNELON, Déa Ribeiro. A formação do profissional de História e a realidade do ensino". Projeto História, São Paulo, n. 2, p. 7-19, 1982.

Sobre a proposta para o ensino de História de $1^{\circ}$ grau. Revista Brasileira de História, São Paulo, v. 7, n. 14, p. 249-254, mar./ago. 1987.

FINLEY, Moses I. Uso e abuso da história. São Paulo: Martins Fontes, 1989.

FRANCISCO, Maria de Fátima S. Preservar e renovar o mundo. Revista Educação, Hannah Arendt Pensa a Educação, São Paulo, n. 4, p. 26-35, 2007.

FREIRE, Paulo. Pedagogia do oprimido. 7. ed. Rio de Janeiro: Paz e Terra, 1979.

FURET, François. A oficina da História. Lisboa: Gradiva, 1986.

GLEZER, Raquel. Novos livros, velhas idéias. Revista Brasileira de História, São Paulo, v. 4, n. 7, p. 149-154, 1984.

GRISET, Antoine. Foucault, um projeto histórico. In: LE GOFF, Jacques et al. A Nova História. Lisboa: Edições 70, 1986. p. 57-63.

HARTOG, François. Primeiras figuras do historiador na Grécia: historicidade e história. Tradução de Francisco Murari Pires. Revista de História, n. 141, p. 9-20, 1999. 
Memória de Ulisses: narrativas sobre a fronteira na Grécia antiga. Tradução de Jacyntho Lins Brandão. Belo Horizonte: UFMG, 2004.

HELLER; Agnes; FEHÉR; Ferenc. A condição política pós-moderna. Tradução de Marcos Santarrita. Rio de Janeiro: Civilização Brasileira, 2002.

HOBSBAWM, Eric. Introdução: a invenção das tradições. In: HOBSBAWM, Eric; RANGER, Terence (Orgs.). A invenção das tradições. Rio de Janeiro: Paz e Terra, 1984.

. A era das revoluções: Europa 1789-1848. Tradução de Maria T. Lopes Teixeira e Marcos Penchel. Rio de Janeiro: Paz e Terra, 1989.

A era dos extremos: o breve século XX. São Paulo: Companhia das Letras, 1995.

. Sobre a História. São Paulo: Companhia das Letras, 1998.

HOUAISS. Dicionário Houaiss eletrônico. São Paulo: Editora Objetiva, 2009. (CD-ROM)

HUISMAN, Denis. Dicionário dos filósofos. São Paulo: Martins Fontes, 2004.

IOKOI, Zilda Márcia Gricoli. Pesquisa e monografia no ensino de $1^{\circ}$ e $2^{\circ}$ graus”. In: SILVA, Marcos A. da (Org.) Repensando a História. São Paulo: ANPUH/Marco Zero, 1984. p. 112117.

JAEGER, Werner Wilhelm. Paidéia: a formação do homem grego. Tradução de Arthur M. Parreira. Adaptação do texto para a edição brasileira por Monica Stahel. Revisão do texto grego por Gilson César Cardoso de Souza. 4. ed. São Paulo: Martins Fontes, 2001.

JASPERS, Karl. Introdução ao pensamento filosófico. 5. ed. São Paulo: Cutrix, 1965.

KANT, Immanuel. Resposta à pergunta Que é “Esclarecimento”? (“Aufklãrung”). In: Textos seletos. Petrópolis: Vozes, 1985.

Crítica da faculdade do juízo. Tradução de Valerio Rohden e Antônio Marques. 2. ed. Rio de Janeiro: Forense Universitária, 2010.

LAFER, Celso. A reconstrução dos direitos humanos: um diálogo com o pensamento de Hannah Arendt. São Paulo: Companhia das Letras, 1988.

Da dignidade da política (prefácio). In: ARENDT, Hannah. Entre o passado e o futuro. São Paulo: Perspectiva, 1992.

. Reflexões de um antigo aluno de Hannah Arendt sobre o conteúdo, a recepção e o legado de sua obra, no $25^{\circ}$ aniversário de sua morte. In: MORAES, Eduardo Jardim de; BIGNOTTO, Newton (Orgs.). Hannah Arendt: diálogos, reflexões, memórias. Belo Horizonte: Ed. UFMG, 2001. Terra, 2003.

Hannah Arendt: pensamento, persuasão e poder. 2. ed., ver. e ampl. São Paulo: Paz e 
Na confluência entre o pensar e o agir: sobre uma experiência com os conceitos de Hannah Arendt. In: DUARTE, André et al. A banalização da violência: a atualidade do pensamento de Hannah Arendt. Rio de Janeiro: Relume Dumará, 2004.

LARROSA, Jorge. Pedagogia profana: danças, piruetas e mascaradas. Tradução de Alfredo Veiga-Neto. 5. ed. Belo Horizonte: Autêntica, 2010.

LAVILLE, Christian. A guerra das narrativas: debates e ilusões em torno do ensino de História. Revista Brasileira de História, São Paulo, v. 19, n. 38, p. 125-138, 1999.

LE GOFF, Jacques. A História nova. São Paulo: Martins Fontes, 1990.

Unicamp, 1996.

Documento/monumento. In: História e memória. Campinas: Editora da

LE GOFF et al. A história: uma paixão nova (mesa-redonda com a participação de Philippe Ariès, Michel de Certeau, Jacques Le Goff, Emmanuel LeRoy Ladurie e Paul Veyne). In: LE GOFF, Jacques et al. A Nova História. Lisboa: Edições 70, 1986.

LE GOFF, Jacques; CHARTIER; Roger; REVEL, Jacques (Orgs.). A História nova. 4 ed. São Paulo: Martins Fontes, 1988.

LE GOFF, Jacques; NORA, Pierre (Orgs.). História: novos problemas, novos objetos, novas abordagens (3 vols.). Rio de Janeiro: Francisco Alves, 1988.

LEFORT, Claude. Hannah Arendt e a questão do político. In: Pensando o político. Rio de Janeiro: Paz e Terra, 1991.

Formação e autoridade: a educação humanista. In: Desafios da escrita política. São Paulo: Discurso Editorial, 1999.

LEVI, Primo. A trégua. Tradução de M. Lucchesi. São Paulo: Companhia das Letras, 2010.

LUDZ, Ursula. Introducción. In: ARENDT, Hannah. Lo que quiero és compreender: sobre mi vida y mi obra. Madrid: Editorial Trotta, 2010.

MAKARENKO, Anton. Poema pedagógico. São Paulo: Editora 34, 2005.

MARSON, Adalberto. Reflexões sobre o procedimento histórico. In: Repensando a História. São Paulo: ANPUH/Marco Zero, 1984. p. 37-64.

MARTÍNEZ, Elena. La história, relato de infinitos comienzos y ningún final. In: CRUZ, Manuel; BIRULÉS, Fina (Comp.). En torno a Hannah Arendt. Madrid: Centro de Estudios Constitucionales, 1994. p. 95-128.

MATTOS, Selma Rinaldi de. O Brasil em lições: a História como disciplina escolar em Joaquim Manuel de Macedo. Rio de Janeiro: Access, 2000.

McCARTHY, Mary. Al contrario. Barcelona: Editorial Seix Barral S.A., 1967. 
2000.

. Posfácio. In: ARENDT, Hannah. A vida do espírito (Querer). Lisboa: Editora Piaget,

MICELI, Paulo. Por outras histórias do Brasil. In: PINSKY, Jaime. O ensino de História e a criação do fato. São Paulo: Contexto, 1988.

MOMIGLIANO, Arnaldo. As raízes clássicas da historiografia moderna. Tradução de Maria Beatriz B. Florenzano. Bauru: EDUSC, 2004.

MORAES, Eduardo Jardim de. Tensão entre teoria e prática. Revista Cult, mar. 2010.

MORAES, Eduardo Jardim de; BIGNOTTO, Newton. Hannah Arendt: diálogos, reflexões, memórias. Belo Horizonte: Ed. UFMG, 2001.

MORAIS, Emília Maria M. de. Educação e política: uma re-leitura de Rousseau. Revista da Faculdade de Educação, v. 12, n. 1/2, p. 199-215, jan./dez. 1986.

MOSSÉ, Claude. Dicionário da civilização grega. Rio de Janeiro: Jorge Zahar Ed., 2004.

MUNAKATA, Kazumi. Produzindo livros didáticos e paradidáticos. Tese (Doutorado) Pontifícia Universidade Católica, São Paulo, 1997.

NADAI, Elza. O ensino de História no Brasil: trajetória e perspectiva. Revista Brasileira de História, São Paulo, v. 13, n. 25/26, p. 143-162, set. 1992/ago. 1993.

NORA, Pierre. O retorno ao fato. In: LE GOFF, Jacques; NORA, Pierre. História: novos problemas. Rio de Janeiro: Francisco Alves, 1988.

Entre memória e história: a problemática dos lugares. Projeto História, São Paulo, v. 10, p. 7-28, dez. 1993.

OAKESHOTT, Michael. Teaching and learning. In: PETERS, Richard Stanley. The concept of education. Londres: Routledge, 1968. (Tradução para o português não publicada de Helena Meidani e José Sérgio Fonseca de Carvalho).

PEIRÓ, Ángela Lorena Fuster. La imaginació arrelada: una proposta interpretativa a partir de Hannah Arendt. Tese (Doutorado) - Faculdade de Filosofia, Universidade de Barcelona, Barcelona, 2005.

PENTEADO, Heloisa Dupas. As relações pedagógicas: a questão da autoridade e do autoritarismo. Revista da Faculdade de Educação da USP, São Paulo, v. 12, n. 1/2, 1986.

PIÑA, Teresa; BARRIOS, Beatriz. Sobre la cuestión de la identidad en la vida de Rahel Varnhagen". In: ARESE, Laura et al. Lecturas de Arendt: II Jornadas Internacionales Hannah Arendt. Córdoba: Universidad Nacional de Córdoba, 2012. (DVD).

PIRES, Francisco Murari. Mithistória. São Paulo: Humanitas Publicações-FFLCH/USP, 1999. 
PORCEL, Beatriz. Hannah Arendt y la crisis de nuestro tiempo. Argumentos: Revista de Filosofia, Fortaleza, ano 5, n. 9, p. 197-204, jan./jun. 2013.

PRESTES, Zoia. Um poema de amor ao ser humano. In: MAKARENKO, Anton. Poema pedagógico. São Paulo: Editora 34, 2005.

RAGO, Margareth. Libertar a História. In: RAGO, Margareth et al. Imagens de Foucault e Deleuze. Rio de Janeiro: DP\&A, 2002. p. 255-272.

RAPCHAN, Eliane Sebeika. Hannah Arendt - Rahel Levin: duas biografias, sujeito e espelho. Cadernos Pagu, v. 22, p. 291-327, 2004.

ROMILLY, Jacqueline de. História e razão em Tucídides. Brasília: UnB, 1998.

ROVIELLO, Anne-Marie. Senso comum e modernidade em Hannah Arendt. Tradução de Bénédicte Houart e João Filipe Marques. Lisboa: Instituto Piaget, 1997.

SADER, Eder. Quando novos personagens entraram em cena. Rio de Janeiro: Editora Paz e Terra, 1988.

SALIBA, Elias Thomé. Experiências e representações sociais: reflexões sobre o uso e o consumo das imagens. In: BITTENCOURT, Circe (Org.). O saber histórico na sala de aula. São Paulo: Contexto, 1997.

Apresentação. In: DOSSE, François. A História em migalhas: dos Annales à Nova História. Tradução de Dulce O. A. dos Santos. Bauru: EDUSC, 2003. p. 17-22.

SCHAFF, Adam. História e verdade. Lisboa: Editorial Estampa, 1974.

SCHEFFLER, Israel. A linguagem da educação. Tradução de Balthazar Barbosa Filho. São Paulo: Edusp/ Saraiva, 1974.

SILVA, Franklin Leopoldo e. O mundo vazio: sobre a ausência da política no contexto contemporâneo. In: SILVA, Doris Accioly e; MARRACH, Sonia Alem (Orgs.). Maurício Tragtenberg: uma vida para as ciências humanas. São Paulo: Editora Unesp, 2001.

SILVA, Tomas Tadeu da. Documentos de identidade: uma introdução às teorias do currículo. Belo Horizonte: Autêntica, 1999.

SILVA, Zélia Lopes da. Asterix e a dominação romana. Revista Brasileira de História, São Paulo, v. 5, n. 10, p. 232-246, mar./ago. 1985.

SOUZA, Maria Cecília Cortez Christiano de. Escola e memória. Bragança Paulista: Ed. IFAN-CDPH, 2000.

STEPHANOU, Maria. Instaurando maneiras de ser, conhecer e interpretar. Revista Brasileira de História, São Paulo, v. 18, n. 36, p. 15-38, 1998.

TAMINIAUX, Jacques. ¿Performatividad y grecomanía?. In: BIRULÉS, Final et al. Hannah Arendt, el legado de una mirada. Sequitur: Madrid, 2008. 
TUCÍDIDES. História da Guerra do Peloponeso. Tradução de Mário da Gama Kury. Brasília: Editora Universidade de Brasília, 1982.

VERNANT, Jean-Pierre. As origens do pensamento grego. São Paulo: DIFEL, 1972.

Mito e sociedade na Grécia Antiga. Tradução de Myriam Campello. Rio de Janeiro: José Olímpio, 1992.

VEYNE, Paul. Como se escreve a História. Lisboa: Edições 70, 1983.

VIDAL-NAQUET, Pierre. O mundo de Homero. Tradução de Jonatas B. Neto. São Paulo: Companhia das Letras, 2002.

VILLA, Dana. Arendt y Sócrates. In: BIRULÉS, Final et al. Hannah Arendt, el legado de una mirada. Sequitur: Madrid, 2008.

VILLALTA, Luiz Carlos. Dilemas da relação teoria e prática na formação do professor de História: alternativas em perspectiva. Revista Brasileira de História, v. 13, n. 25/26, p. 223 232, set. 1992/ago. 1993.

WAGNER, Eugênia Sales. Hannah Arendt e Karl Marx: o mundo do trabalho. Cotia: Ateliê Editorial, 2002.

Hannah Arendt: ética \& política. Cotia: Ateliê Editorial, 2006.

WHITE, Hayden. Trópicos do discurso: ensaios sobre a crítica da cultura. São Paulo: EDUSP, 1994.

YOUNG-BRUEHL, Elisabeth. Hannah Arendt: por amor ao mundo. Tradução de Antônio Trânsito, Revisão técnica de Eduardo J. de Moraes. Rio de Janeiro: Relume Dumará, 1997.

ZAMBONI, Ernesta. Sociedade e trabalho e os primeiros anos de escolaridade - introdução das noções básicas para a formação de um conceito: trabalho. Revista Brasileira de História, São Paulo, v. 6, n. 11, p. 117-125, set. 1985/fev. 1986.

O conservadorismo e os paradidáticos de História. Revista Brasileira de História, São Paulo, v. 13, n. 25/26, p. 175-192, set. 1992/ago. 1993.

ZITELli, Lucia M. Ricco. A autonomia do político em Hannah Arendt. Dissertação (Mestrado) - Faculdade de Educação, Universidade de São Paulo, São Paulo, 1997. 